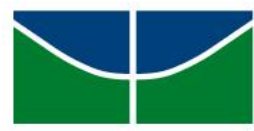

Universidade de Brasília

Centro de Excelência em Turismo

Mestrado Profissional em Turismo

DANIELA CARVALHO BEZERRA LEITE

FEIRAS COMO ESPAÇOS DE HOSPITALIDADE E IDENTIDADE COLETIVA:

FEIRA PERMANENTE DA CEILÂNDIA/DF 
DANIELA CARVALHO BEZERRA LEITE

FEIRAS COMO ESPAÇOS DE HOSPITALIDADE E IDENTIDADE COLETIVA: FEIRA PERMANENTE DA CEILÂNDIA/DF

Dissertação apresentada ao Programa de Pós-Graduação Mestrado Profissional em Turismo do Centro de Excelência em Turismo da Universidade de Brasília como requisito parcial para obtenção do título de Mestre.

Área de Concentração: Cultura e Desenvolvimento Regional.

Orientadora: Prof. Dra. Marutschka Martini Moesch. 
Ficha catalográfica elaborada automaticamente, com os dados fornecidos pelo(a) autor(a)

Leite, Daniela Carvalho Bezerra

Feiras como espaços de hospitalidade e identidade coletiva: Feira Permanente da Ceilândia/DF / Daniela Carvalho Bezerra Leite; orientador Marutschka Martini Moesch. -- Brasilia, 2015.

$165 \mathrm{p}$.

Dissertação (Mestrado - Mestrado Profissional em Turismo) -- Universidade de Brasilia, 2015.

1. Feira Permanente da Ceilândia/DF. 2 . Hospitalidade. 3. Comensalidade. 4. Convivência. 5. Turista cidadão. I. Moesch, Marutschka Martini. orient. II. Título. 


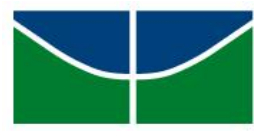

Universidade de Brasília

Centro de Excelência em Turismo

Mestrado Profissional em Turismo

DANIELA CARVALHO BEZERRA LEITE

\title{
FEIRAS COMO ESPAÇOS DE HOSPITALIDADE E IDENTIDADE COLETIVA: FEIRA PERMANENTE DA CEILÂNDIA/DF
}

\begin{abstract}
Dissertação apresentada ao Programa de Pós-Graduação Mestrado Profissional em Turismo do Centro de Excelência em Turismo da Universidade de Brasília como requisito parcial para obtenção do título de Mestre.

Área de Concentração: Cultura e Desenvolvimento Regional.

Orientadora: Prof. Dra. Marutschka Martini Moesch.
\end{abstract}

Aprovação em: 08 de junho de 2015.

BANCA EXAMINADORA

Prof. ${ }^{a}$ Dr. ${ }^{a}$ Marutschka Martini Moesch - Centro de Excelência em Turismo/UnB (Orientadora)

Prof. Dr. Fernando Luiz Araujo Sobrinho - Departamento de Geografia/UnB

Prof. ${ }^{a}$ Dr. ${ }^{a}$ Lana Magaly Pires - Centro de Excelência em Turismo/UnB 
Dedico esta dissertação aos meus pais, Diva e Edi, sempre presentes e participativos, por perceberem que os desgastes emocionais originados pelas constantes reconstruções causadas pelo mestrado exigiram doses elevadas de amor e paciência. Aos irmãos Guilherme, Anna e Renato por suportar meu estresse e por sempre torceram por mim. 


\section{AGRADECIMENTOS}

Embora solitário o ato de leitura e escrita, a construção desta dissertação não foi um processo realizado sozinha.

Especialmente agradeço ao Instituto Federal de Brasília por incentivar e possibilitar a qualificação de seus docentes.

Aos servidores do IFB Campus Riacho Fundo pelo apoio durante toda a caminhada do mestrado, do processo seletivo à defesa da dissertação, em particular aos colegas Mariana Veras, Maíra Cardoso e Gabriel Rocha.

A todos os Professores do Mestrado Profissional em Turismo do Centro de Excelência em Turismo da Universidade de Brasília, que tanto descontruíram meu objeto de estudo que acabaram por descontruir a mim mesma e, principalmente à minha orientadora, Marutschka Moesch, pelo conhecimento compartilhado, dedicação e empenho durante toda a caminhada da dissertação.

Aos colegas de curso pelas conversas descontraídas que enlouqueciam e alegravam, que destruíam conceito estabelecidos e desvelavam novos, que dividiram comigo momentos felizes e de angústias.

À Banca examinadora pelas considerações pertinentes e enriquecedoras.

Aos amigos e amigas, novos e de uma vida, que de alguma forma ajudaramme a construir este trabalho. 


\section{RESUMO}

Esta dissertação trata das feiras como espaços de hospitalidade e identidade coletiva. O objetivo é analisar os processos de hospitalidade, comensalidade e convivência que ocorrem na feira Permanente da Ceilândia/DF. A investigação se desenvolve utilizando o método qualitativo de caráter exploratório/explicativo. O método de investigação da pesquisa foi o estudo de caso - Feira Permanente da Ceilândia/DF por meio da observação participante, entrevista e imagens fotográficas que serviram para obter o conhecimento amplo e profundo dos símbolos que refletem o pensamento e as ações dos atores. O campo simbólico de Bourdieu conduziu a análise da hospitalidade, comensalidade e convivência praticados na feira como formas de expressão cultural múltipla no Distrito Federal. A etnografia foi utilizada para reconstruir os achados a fim de responder o problema de pesquisa: se as feiras desempenham o papel de ressignificação da identidade coletiva a partir da hospitalidade, comensalidade e convivência. Assim esclarece o que ali ocorre e registra o significado do acontecimento. O estudo evidenciou que a feira possibilita para além de espaço de comércio um lugar de hospitalidade e, portanto, propenso a acolher o turista como espaço de prática cultural.

Palavras-chave: Feira Permanente da Ceilândia/DF. Hospitalidade. Comensalidade. Convivência. Turista Cidadão. Culturas Híbridas. 


\begin{abstract}
The thesis deals with fairs as spaces for hospitality and collective identity. The purpose is to analyze the processes of hospitality, edibility and coexistence that happen in the Permanent Fair of Ceilândia/DF. The research is developed by using the qualitative method and exploratory analysis. The survey research method was the case study the Permanent Fair of Ceilândia/DF - using the participant observation, interviews and photographic images that served to obtain broad and deep knowledge of symbols that reflect the thoughts and actions of the actors. The Bourdieu's symbolic field conducted the analysis of hospitality, edibility and coexistence experienced at the fair as multiple forms of cultural expression in the Federal District. Ethnography was used to reconstruct the findings in order to answer the research problem: if fairs play the role of redefinition of collective identity from the hospitality, edibility and coexistence. So it clarifies what happens there and records the significance of the event. The study showed that the fair provides beyond a commercial space a place of hospitality and therefore prone to welcome tourists as a cultural space.
\end{abstract}

Keywords: Permanent Fair of Ceilândia/DF. Hospitality. Edibility. Coexistence. Tourist Citizen. Hybrid Culture. 


\section{LISTA DE IMAGENS E CROQUI}

Imagem 1: Plano da Cidade de Madrid ..................................................... 22

Imagem 2: Feira de Santana 1930 ......................................................... 25

Imagem 3: Interior do mercado de São José- Recife/PE............................. 28

Imagem 4: Exterior do mercado de São José - Recife/PE.............................. 29

Imagem 5: Feira de Caruaru/PE......................................................... 33

Imagem 6: Victor Pellechia.................................................................... 42

Imagem 7: Brasília em construção............................................................. 43

Imagem 8: Vila Amaury 1959, atual Lago Paranoá....................................... 44

Imagem 9: Principais Feiras do DF........................................................ 57

Imagem 10: Ceilândia........................................................................... 69

Imagem 11: Projeto Centro Metropolitano.................................................. 72

Imagem 12: Linhas e Estações Metrô-DF................................................. $\quad 74$

Imagem 13: Distância do Centro Metropolitano à Feira da Ceilândia............ 76

Imagem 14: Faixada da Feira da Ceilândia................................................. $\quad 78$

Imagem 15: Conjunto Nacional............................................................... 79

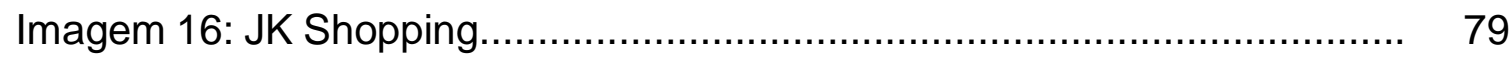

Imagem 17: Bancas de Confeç̧ão.......................................................... 80

Imagem 18: Banca de Calçados........................................................... 80

Imagem 19: Banca de Temperos........................................................ 81

Imagem 20: Banca de Queijos e Doces..................................................... 81

Imagem 21: Banca de Hortifruti............................................................... 82

Imagem 22: Banca de Hortifruti.............................................................. 82

Imagem 23: Banca de Secos e Cereais.................................................. 83

Imagem 24: Bancas de Alimentação........................................................ 84 
Imagem 25: Banca Rei do Mocotó............................................................. 86

Imagem 26: Estrutura das Bancas de Alimentação...................................... 87

Imagem 27: Visão Lado Direito do Croqui da Feira...................................... 87

Imagem 28: Visão Lado Superior do Croqui da Feira.................................. 88

Imagem 29: Visão Lado Esquerdo do Croqui da Feira................................ 88

Imagem 30: Visão Lado Inferior do Croqui da Feira....................................... 88

Imagem 31: Cardápio da banca Kome in Pé............................................... 93

Imagem 32: Fachada Banca da Galega 1.............................................. 93

Imagem 33: Fachada Banca da Galega 2............................................ 94

Imagem 34: Banca Estação Nordeste.................................................... 125

Imagem 35: Fachada da Banca Esquina Sabor Nordeste.............................. 125

Imagem 36: Bancas de Calçados............................................................. 127

Imagem 37: Banca de Moda............................................................... 128

Imagem 38: Banca de Utensílios........................................................... 128

Imagem 39: Banca de Temperos......................................................... 129

Imagem 40: Comidas Típicas ................................................................ 129

Imagem 41: Bancas de modismo global da Feira da Ceilândia...................... 131

Imagem 42: Banca de Aves Vivas......................................................... 132

Imagem 43: Galinha adquirida na banca de aves vivas.............................. 133

Imagem 44: Montagem de Prato de Comida............................................... 135

Croqui 1: Feira Permanente da Ceilândia................................................... 85 


\section{LISTA DE TABELA}

Tabela 1: Leis da cidade de São Paulo relacionadas às feiras-livres...........

Tabela 2: Grupo de Atividades Comércio e Serviços no Brasil.................... 37

Tabela 3: Comércio Varejista com Loja................................................... 37

Tabela 4: Pessoas que não residiam no município da Unidade da Federação em 01.09.1991, mas residiam em 01.09.1996.....

Tabela 5: Renda Domiciliar e Per Capita Mensal, segundo as Regiões Administrativas do Distrito Federal (2004)................................................

Tabela 6: População por sexo segundo Regiões Administrativas do DF (2013)

Tabela 7: População imigrante segundo a naturalidade - Ceilândia (2013)

Tabela 8: Modo de preparo do Mocotó das bancas da Feira da Ceilândia. 


\section{LISTA DE GRÁFICOS}

Gráfico 1: População imigrante do Distrito Federal por Naturalidade -2004... 49

Gráfico 2: População imigrante do Distrito Federal por Naturalidade - 2011.. 49

Gráfico 3: Despesas, receitas orçamentárias e PIB do DF......................... 51

Gráfico 4: População Residente por Região Administrativa......................... 53

Gráfico 5: Os elementos dos dois circuitos............................................. 54

Gráfico 6: População imigrante, segundo a naturalidade - Ceilândia/DF -

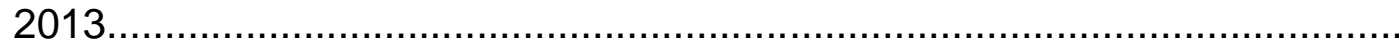


1 HISTÓRICO DAS FEIRAS COMO ESPAÇO DE COMÉRCIO E 17 SOCIALIZAÇÃO..

$1.1 \quad$ Histórico do Surgimento das Feiras de Rua................................................. 17

1.2 Dinâmica Comercial das Feiras de Rua as Lojas de Departamento............... 34

$1.3 \quad$ O Distrito Federal e as Feiras............................................................... 39

2 DO OBJETO VISÍVEL A SUA ESSÊNCIA: O VALOR SIMBÓLICO DO ENCONTRO NA FEIRA DA CEILÂNDIA................................................. 62

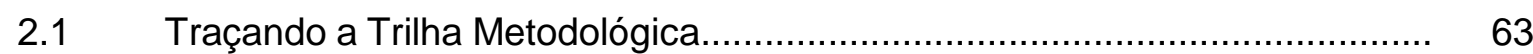

2.2 Descrevendo o Objeto de Estudo - A Feira da Ceilândia.............................. 66

2.2.1 Histórico da Feira Permanente de Ceilândia/DF - Estudo de Caso............... 75

2.2.2 Relato Etnográfico da Feira Permanente da Ceilândia................................. 77

2.3 Para Além do Visível o Papel da Teoria..................................................... 100

3 FEIRA PERMANENTE DA CEILÂNDIA COMO ESPAÇO DE HIBRIDIZAÇÃO CULTURAL.................................................................. 110

3.1 Socialização: Hospitalidade, Convivência e Comensalidade......................... 112

3.2 Reconstrução da Identidade Coletiva nas Práticas de Comensalidade da Feira da Ceilândia......................................................................... 124

CONSIDERAÇÕES FINAIS........................................................................ 143

REFERENCIAS........................................................................................... 152

APÊNDICE I: Questões Orientativas para Entrevista Feirante da Feira da 161 Ceilândia.

APÊNDICE II: Questões Orientativas para Entrevista Frequentadores Feira da 162 Ceilândia.

APÊNDICE III: Tabela - Leis do Distrito Federal sobre Feiras. 


\section{INTRODUÇÃO}

Espaços de comercialização de produtos e circulação de cultura, as feiras e mercados guardam traços culturais marcantes da cidade, desempenham papel de importância social e cultural tanto para visitantes como para feirantes. Segundo Pierre (2010) ao comparar as feiras aos super, ou hipermercados, conclui que nem todos os produtos podem ser obtidos em espaços de comércio estandatizados, diferentes das feiras onde há a relações de proximidade, afetividade e troca de saberes.

Nesse contexto o tema da dissertação trata sobre as feiras como espaços de hospitalidade e identidade coletiva onde a Feira Permanente da Ceilândia/DF é o fragmento estudado.

O processo de hospitalidade culmina na comensalidade, que significa comer e beber juntos. Para Boff (2006) sentar-se à mesa, partilhar o alimento, comungar o cotidiano traz o sentimento de pertencimento àquele grupo. A pós-modernidade alterou de tal forma a vida cotidiana que o se sentar à mesa, no sentido pleno da comensalidade e da livre conversação, tornou-se um momento raro. A problemática se acentua ao nos depararmos segundo Krippendorf (2003) com a bipolarização do homem: trabalhar aqui - morar ali - repousar em outro lugar. Tudo isso porque as cidades estão cada vez mais interessadas em concentrar na porção central unidades produtoras e menos preocupadas com as necessidades dos que por ali vivem. Conhecer a respeito da comensalidade nas feiras é conhecer as formas de convivência que ali são praticadas.

Sendo o alimento símbolo do encontro e da comunhão, esse estudo propõe relacionar a hospitalidade e identidade coletiva com as feiras pelos alimentos, bebidas, atendimento personalizado e sentimento de pertencimento que ocorre na Feira Permanente da Ceilândia/DF. Os valores simbólicos e históricos da gastronomia desta feira serão analisados a fim de identificar e entender a existência de uma cultura híbrida, ou não, que representa Brasília.

O referencial teórico passa pela compreensão das categorias de análise como: pertencimento, comensalidade, hospitalidade, convivência, identidade coletiva, cultura hibrida, turismo cidadão, feiras e mercados e sua ressignificação a partir dos autores: Leonardo Boff, Nestor Canclini, Carlos Alberto Dória, Lucio Grinover, Marutschka Martini Moesch, Susana Gastal, Leny Sato, Luis Mott, Roberto DaMatta, 
Massimo Montanari, Clifford Geertz, José Bernardo Toro, Milton Santos, Gaston Bachelard e Stuart Hall.

O caminho metodológico trilhado foi uma pesquisa qualitativa de nível exploratório e explicativa. O estudo de caso é o método de investigação, onde a Feira Permanente da Ceilândia foi eleita entre as demais feiras do Distrito Federal por ser o fragmento de uma totalidade representativa. Esta escolha deveu-se ao fato da Região Administrativa Ceilândia ter a maior densidade urbana somado a um histórico de exclusão/tentativa de isolamento desde sua fundação. A etnometodologia foi utilizada como caminho para reconstrução dos achados a fim de responder as seguintes questões de pesquisa:

- Como se expressa a hospitalidade no encontro possibilitado pela feira de Ceilândia?

- Como se expressa a comensalidade no encontro possibilitado pela feira de Ceilândia?

- Como se expressa a convivência no encontro possibilitado pela feira de Ceilândia?

- A feira da Ceilândia pode ser considerada um espaço de experiência turística?

- O que leva o feirante da feira de Ceilândia a incluir um prato de origem regional no cardápio de sua banca sendo uma feira no DF?

- Existe algum processo diferenciado de atendimento ao cliente na feira de Ceilândia que identifique as características de origem regional?

- Em que aspectos da cultura regional os frequentadores da feira de Ceilândia se reconhecem?

- Qual a relação de pertencimento/identificação que os feirantes têm com a feira?

- Qual a relação de pertencimento/identificação que os visitantes têm com a feira?

- A feira da Ceilândia é um espaço de representação das diferentes culturas regionais do Brasil no DF?

Dizer que a Ceilândia possui uma cultura gastronômica resultante da mistura de outras culturas não basta. É preciso investigar a relação entre candangos, brasilienses e território para se estabelecer uma possível definição do que seria a 
identidade coletiva de Ceilândia, onde as memórias e os saberes e fazeres podem ser pesquisados, ainda hoje, com a primeira geração.

Com esse objetivo no primeiro capítulo a origem e evolução das feiras no mundo, Brasil e Distrito Federal/Brasília foram contextualizadas historicamente, em sequência cronológica. No segundo capitulo foi trabalhado a trilha metodológica, a descrição do objeto de estudo pelo histórico e relato etnográfico da feira Permanente da Ceilândia e a teorização das categorias operatórias pertencimento, hospitalidade, turismo cidadão, comensalidade, convivência, identidade coletiva e cultura hibrida. No terceiro capitulo é ressignificado e investigado os modos de saber/fazer na Feira Permanente da Ceilândia que desvela um processo de hibridização cultural. No quarto capítulo os objetivos da dissertação são recuperados e combinadas às questões de pesquisa respondendo-os finalizando assim a dissertação de forma articulada com o problema construído e a trilha metodológica realizada.

Com o intuito de retirar a população de baixa renda, que vivia em acampamentos e favelas no Plano Piloto e arredores, a cidade de Ceilândia foi criada para abrigar os candangos no início da década de 70 . Com eles vieram para a nova cidade memórias, técnicas, arte, regras entre outros de regiões distintas do Brasil. Mais da metade da população da Ceilândia é natural do próprio Distrito Federal e mora na região administrativa há 15 anos ou mais. Dos que vieram de outros estados brasileiros, a maioria é do Piauí $(7,2 \%)$, de Minas Gerais $(6,9 \%)$ e de Goiás $(6,1 \%$, segundo dados Anuário do Distrito Federal (2012).

A feira de Ceilândia, inaugurada em 1984, é ponto de encontro da comunidade local e possui em sua fachada o slogan "Feira Central de Ceilândia nasceu e cresceu junto com a cidade!". A Feira Central com 460 boxes dos mais diversos segmentos, vestuário, calçados, utilidades para o lar e alimentação, recebe cerca de dez mil visitantes por semana. No início, os feirantes dos cerca de trinta boxes ocupados pelo segmento de alimentação eram os candangos que preparavam e vendiam pratos típicos de suas origens. Hoje se nota a presença dos filhos dos candangos, os brasilienses, que receberam os ensinamentos e o empreendimento comercial da geração anterior. Nesse processo, novos modos de fazer foram inventados e insumos foram substituídos, adaptados ao paladar local.

Para a gastronomia, como identificação de uma cultural, a elaboração de pratos que reproduzam a marca regional ou nacional de identificação deve estar em conformidade com aspectos culturais e técnico/tecnológicos da sociedade. Dessa 
forma a comensalidade na feira da Ceilândia é analisada a partir das heranças nordestinas, goianas e mineiras, onde ora uma se sobrepões às outras ora se mistura. Ainda, é investigada a relação entre candangos, brasilienses e território para se estabelecer uma possível definição do que seria a identidade cultural da feira da Ceilândia.

A feira permanente da Ceilândia é um bem de referência cultural registrado no DF e Entorno. O registro é um ato jurídico-administrativo realizado pelo Poder Público cujo bem registrado deve representar a identidade cultural de determinado grupo e tem por objetivo preservar bens de natureza imaterial (GOVERNO DO DISTRITO FEDERAL, 2014).

A pesquisa pautou-se na identificação e registro de uma cultura gastronômica enriquecida pela junção de tradições múltiplas expressas na culinária apresentada na feira Permanente da Ceilândia, o que possibilitou traçar um estudo das manifestações culturais para identificar a existência de uma identidade própria. Assim, a gastronomia foi o ponto de entrada para o estudo da comensalidade, convivência, sentimento de pertencimento, identificação, cultura híbrida e turismo cidadão tendo a hospitalidade a função de aprofundar o entendimento dos processos. Identificar e registrar uma prática social e cultural própria, legitimada pelos valores simbólicos dá sentido de permanência e pertencimento ao fato estudado. Mesmo que este fato se modifique com o passar do tempo ele é um instrumento de integração social que contribui para a construção de um coletivo. 


\section{HISTÓRICO DAS FEIRAS COMO ESPAÇO DE COMÉRCIO E SOCIALIZAÇÃO}

A alimentação motivou a necessidade de fixação territorial, de trocas e comercialização de produtos agrícolas, de grandes conquistas comerciais causadoras de ampliação de fronteiras e de guerra ao longo da história.

As feiras de rua foram os primeiros espaços de comercialização dessa produção agrícola. Considerando-se as lacunas documentais sobre o tema, o capítulo está estruturado, em sequência cronológica a fim de contextualizar as feiras comerciais, sejam elas chamadas de rua, livres, públicas, comerciais ou simplesmente feiras, os mercados e o comércio ambulante como possibilidades, as vezes única, de abastecimento e como espaços público e de socialização.

Feiras e mercados possuem muitas semelhanças tanto estruturais como em suas funções, e ainda, segundo Ferreti (2000, p. 39) "No Brasil, as feiras e mercados apresentam tantas variações que torna-se difícil a enumeração de características gerais capazes de distinguir essas duas instituições nas diversas regiões brasileiras onde elas são encontradas".

Retomar a história sobre a origem e evolução das feiras no mundo, Brasil e Distrito Federal/Brasília é inserir o entendimento nesta pesquisa da complexidade e impermanência da relação indivíduo/sociedade. É ainda, não reduzir as feiras e mercados às relações de compra e venda.

\subsection{Histórico do Surgimento das Feiras de Rua}

O comércio desde a Antiguidade fomenta o desenvolvimento da economia, dos meios de transporte, dos meios de comunicação e do intercâmbio cultural entre as comunidades.

A substituição da economia primitiva coletora pela economia agrícola iniciase no Oriente Médio por volta de 6.500 a.C. segundo Magalhães Filho (1978), quando o homem aprendeu o processo da agricultura. Para o mesmo autor o aprendizado deu-se em diversos locais de maneira autônoma ou pelo contato entre os povos. Para Magalhães Filho (1978) devido à fertilidade da terra e ao trabalho do próprio homem, 
os povos cujos estados de evolução eram mais avançados estavam situadas nos vales dos rios Nilo, Tigre e Eufrates, Indo e Amarelo.

No vale do rio Nilo, no Egito do Antigo Império os excedentes eram armazenados para os anos seguintes. Por volta de 2.000 a.C. é formado o Médio Império onde Tebas, a maior cidade do Egito, mesmo durante o período de decadência do país, se desenvolve por causa da sua posição geográfica como entreposto comercial. Para Magalhães Filho (1978) a expansão da produção agrícola e a introdução de outras atividades econômicas como a metalurgia do ferro e a fabricação do vidro expandiram as atividades comerciais do Médio Império por rotas marítimas e terrestres.

Entre os rios Tigres e Eufrates situou-se a Mesopotâmia que atingiu grau semelhante de desenvolvimento produtivo que os egípcios do Antigo Império. Praticavam o comércio entre as cidades através dos rios, canais e lagos. No Paquistão, noroeste da Índia no vale do Indo, os hindus desenvolveram-se como o Médio Império egípcio, organizados em cidades com características das civilizações agrícolas. Em 2.200 a.C. surge no curso do rio Amarelo a civilização chinesa. Em 3.000 a.C. formam-se as primeiras comunidades agrícolas dessa civilização. 0 período de 202 a.C. a 221 d.C. é um período de expansão da civilização chinesa, de ligação do Oriente com o Ocidente, momento transitório da economia agrícola para a comercial.

\footnotetext{
A população cresce até atingir 60 milhões de pessoas. O comércio desenvolve-se, abrindo-se a chamada Rota da Seda, através do vale do Tarim e dos montes Tien Shan, que pôs a China em contato com as civilizações indo-européias do Irã e da Índia, levando a seda e os objetos de bronze e jade chineses até os mercados do Mediterrâneo. (MAGALHÃES FILHO, 1978, p. 57)
}

No século VIII a.C. os gregos, por terem posição geográfica privilegiada possibilitaram que seus mercadores estabelecessem relações comerciais com diversas regiões da Europa Ocidental e pelo interior do Continente Asiático. Essas rotas foram utilizadas mais tarde pelos romanos para impulsionar seu comércio.

A civilização agrícola dá espaço a civilização comercial quando o comércio passa a ser, segundo Magalhães Filho (1978, p. 69) "o meio de obtenção daqueles bens que não podiam ser obtidos dentro de cada economia local ou regional". Para aquisição desses bens foram desenvolvidas as rotas comerciais terrestres e 
posteriormente as rotas marítimas e fluviais. Assim, as forças produtivas libertam o homem da dependência primitiva à terra e natureza e lançam as civilizações para a liberdade.

\begin{abstract}
Foram as atividades comerciais que transformaram certas aldeias em cidades. Em certos casos por serem os centros de regiões cujos produtores ali se reuniam, em certas épocas fixas de cada ano, para trocarem ou venderem seus excedentes e adquirirem o que necessitavam e não podiam produzir sozinhos. Eram as cidades-feiras, cuja importância variava em razão direta do tamanho e da riqueza de sua área de atração, e onde tendiam a fixar-se as mais diversas atividades artesanais. Em outros casos 0 desenvolvimento urbano era provocado pela localização estratégica às margens ou no cruzamento de rotas comerciais ou no ponto de transbordo entre as rotas terrestres e as marítimas. (MAGALHAES FILHO 1978, p. 70)
\end{abstract}

Mesmo o desenvolvimento urbano das cidades ser do tipo comercial a economia comercial dependia da produção agrícola, ficando as civilizações comerciais, a priori, como intermediários, como é o caso de uma das primeiras civilizações comerciais, os fenícios.

A falta de terras produtivas na região litorânea noroeste do Oriente Médio, onde hoje se localiza o litoral da Síria e do Líbano, diferentemente do que ocorria na Mesopotâmia e Egito, levou os fenícios a se dedicarem à troca de produtos com diversos povos da Antiguidade. A desvantagem relacionada à fertilidade do solo era compensada pela região ser atravessada, segundo Magalhães Filho (1978, p.74), "pelas únicas rotas comerciais existentes entre as duas grandes civilizações da época".

A economia comercial deu lugar ao feudalismo, desagregando as relações comerciais. Porém o comércio não desapareceu, ao contrário, quanto mais prosperava o feudalismo mais o comércio era estimulado e a necessidade e desejo de consumo nas cidades aumentado.

\footnotetext{
Nos primeiros séculos do feudalismo os elementos característicos do comércio são as feiras locais e mercados ambulantes. A maior parte da produção é consumida dentro dos feudos onde é produzida. [...] As pequenas cidades e vilas eram, por sua vez, abastecidas pelos produtores vizinhos, que iam até elas e vendiam diretamente ao consumidor. (MAGALHÃES FILHO, 1978, p. 142)
}

A história das feiras se liga à do comércio. Mott (1976), Araujo (2005) e Rau (1982) concordam que é na Idade Média, que as feiras nascem, como essência do comércio da época medieval. Rau (1982) completa que as feiras se originam na 
necessidade dos homens do campo e da cidade realizarem trocas de produto, tornando-se "um dos aspectos mais importantes da organização econômica da Idade Média" (RAU, 1982, p. 33). Para Magalhães Filho (1978) a feira mais antiga surge no século IX. É a feira de Saint-Denis localizada próximo a Paris na França. Porém, acrescenta, as grandes feiras se desenvolvem três séculos depois quando passam a acontecer nas cidades localizadas nas proximidades das principais rotas comerciais, ficando a região de Champanha, também na França, como destacado ponto de encontro dos grandes mercadores. As principais feiras aconteciam em Troyes, Provins, Lagny, Bar-sur-Arube e Chalons-sur-Marne.

O mercador ambulante, segundo Magalhães Filho (1978) era o elo da rede comercial da Europa feudal que seguia de feira em feira comprando em uma para vender em outra. Alguns se especializaram e passaram a vender grandes quantidades de um mesmo produto. A partir do século XII, com a evolução do transporte fluvial, o transito e comercio de mercadorias foi facilitado colocando as feiras locais e os pequenos mercadores atendendo diretamente o consumidor. $O$ grande mercador realizava suas atividades nos séculos XII e XIII nas grandes feiras que se localizavam no ponto de encontro das principais rotas comerciais. As grandes feiras eram, ainda conforme Magalhaes Filho (1978), de grande importância para a região, realizadas no máximo duas vezes por ano e com o caráter da venda a atacado. A partir do século XIV as grandes feiras passam a ser somente para a exposição de amostras dos produtos uma vez que seu transporte estava onerando e consequentemente desestimulando a atividade. A tecnologia das comunicações promoveu nova alteração, as vendas passam a ser realizadas por correspondência diminuindo ainda mais a necessidade de ser realizar feiras fazendo com que as grandes feiras passem ao papel secundário na evolução comercial europeia.

Bakhtin (1993) remete-se as feiras como parte das festas na Idade Média ao discorrer sobre a vida cotidiana do homem medieval como representação popular cômica, pública e tradicional, onde os ritos e espetáculos cômicos que levam ao riso se referem a vida particular, a vida cotidiana. Nesse período feudal as festas tinham caráter de momento para esquecer-se do tempo do trabalho, representando uma visão do homem e das relações humanas. Uma dualidade entre o mundo oficial e o mundo cotidiano, cujo vida de trabalho é separada da vida cotidiana. Dessa forma as festas eram a segunda vida do povo, quando os mesmos entravam em contato com a vida utópica, universal, libertadora, igualitária e abundante. Com o autor pode-se 
traçar um comparativo entre os mercados da modernidade e as feiras, onde os mercados são locais sem liberdade e contínua permissividade em relação a vida oficial enquanto que nas feiras o clima é de festejo e convivência. Rau (1982) também faz um estudo entre mercados e feiras e acrescenta que "o mercado mantinha a população, a feira contribuía para o desenvolvimento populacional onde se realizava" (RAU, 1982, p. 59).

Os mercados parecem sintetizar o que um historiador considerou as duas formas clássicas de socialização nas primeiras cidades: a praça aberta e o bazar coberto e a rua de barracas ou de lojas, possivelmente em cidades dos anos 2.000 antes da era cristã. Com o Renascimento Europeu, o mercado volta à praça central da cidade ou criam-se praças de mercado. (LEAL, 2011, p. 13)

As feiras se desenvolvem em maiores números dado o renascimento do comércio europeu no século XI e das peregrinações e festividades. "As romarias, as peregrinações e todas as festividades religiosas atraíam peregrinos vindos de longe, e como o peregrino era também muitas vezes um mercador, essas reuniões estavam destinadas a transformar-se em centros de troca". (RAU, 1982, p. 33)

A igreja era poderosa, influente e rica no século XII. Somente na França existiam 2000 mosteiros que pertenciam a religiosos como beneditinos, franciscanos ou cistercienses, os quais desenvolveram consideravelmente a arte de cozinhar e desempenharam um papel importante na gastronomia. Conforme Leal (1998) os monges herdaram os conhecimentos da cozinha romana e transmitiram para outros povos da cidade e foram os responsáveis por mudanças importantes na cozinha da Idade Média. Assim, reavivaram a agricultura, desenvolveram a jardinagem levando frutas e verduras às mesas, exploraram minas de sal, praticaram a pecuária, aprimoraram a conservação dos alimentos e fabricaram pão. Os mosteiros medievais também serviam de armazém de alimentos para a população da redondeza que passaram a vender alimentos nas feiras livres. Rau (1982) indica que muitas feiras originaram-se próximo as capelas e que relacionavam-se com as festas da Igreja Católica.

Ao analisar a constituição das cidades espanholas da Idade Média nota-se configurações similares de influência romana. Rodeadas por muros a cidade se construía em desenho circular, quadrado ou retangular. A partir de 1212, segundo Fuster (1971, p. 292), "hay ya um intento de desbordar la muralla com uma ânsia de 
crescimento urbanístico que inician las iglesias y monasteiros". Assim, as cidades da Idade Média criam identidade própria constituída pelos elementos exemplificados na imagem 1 sobre o recorte do plano da cidade de Madrid onde as ruas principais “convergían em la Plaza Mayor, de soportales, donde se celebra el mercado diário, com la venda de los produtos agrícolas de consumo normal”. (FUSTER, 1971, p. 292)

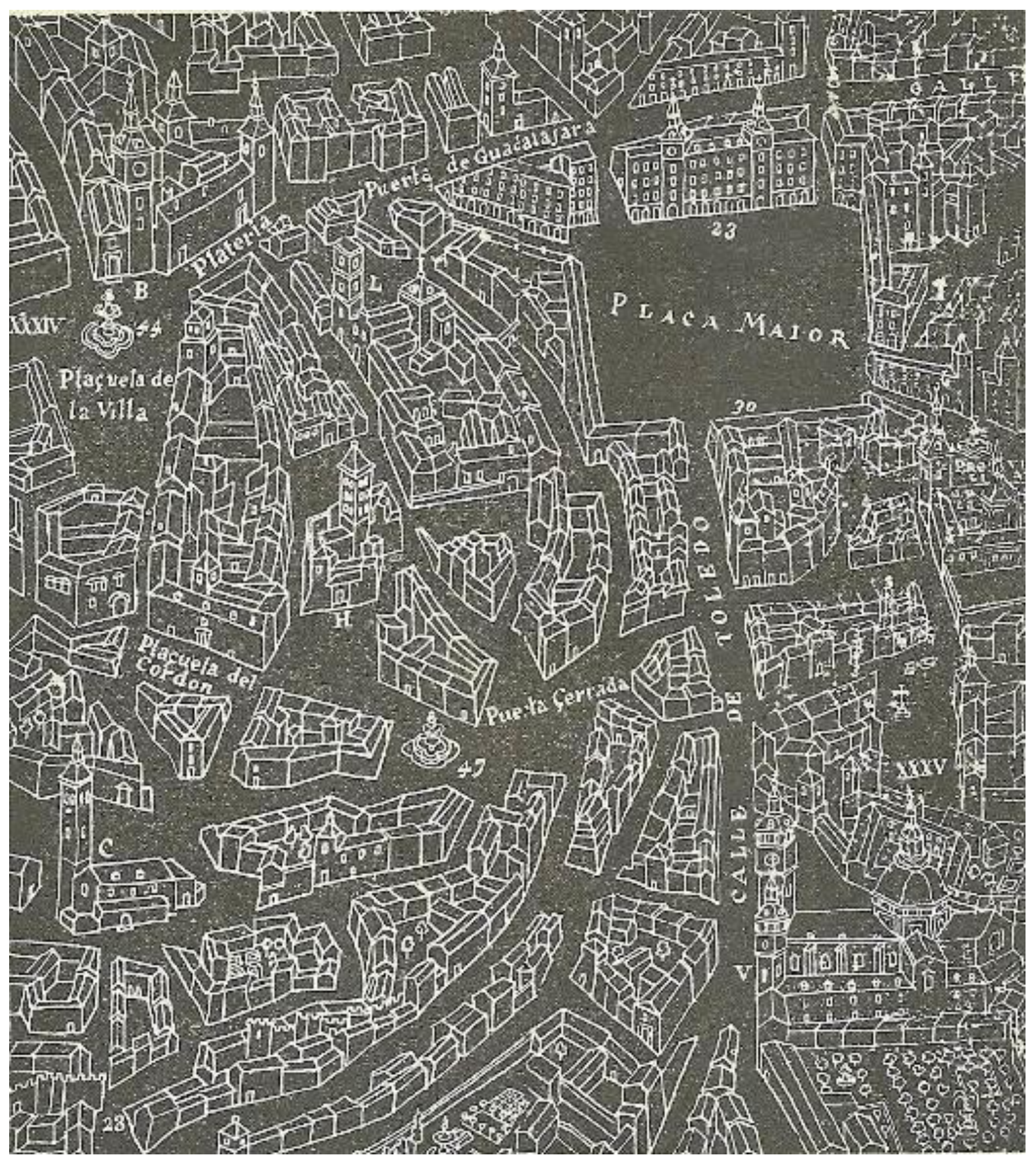

Imagem 1: Plano da Cidade de Madrid

Fonte: FUSTER, 1971, p.293. 
Para Sato (2012) "na Idade Média, o que se denominava como feiras eram as grandes reuniões de comerciantes de várias regiões europeias que comercializavam os mais diversos produtos". (p.35)

As feiras contribuíram para a economia internacional, mas também tinham um papel social e cultural importantes pois essas reuniões citadas por Sato poderiam ser, segundo Rau (1982) os únicos momentos de sociabilidade da época medieval. "Foram as romarias e as feiras que aproximaram os homens e teceram a trama de uma unidade espiritual maior". (RAU, 1982, p. 55)

Até o período das Cruzadas (1095 d.C. a 1291 d.C.) Constantinopla tornouse a ligação comercial entre Europa e Ásia. Com a invasão turca o comércio entre Europa e Ásia pelo Mar Mediterrâneo Oriental fica dificultado, forçando os europeus a procurarem novos caminhos para a Ásia.

Com a queda do Império Romano e o desenvolvimento do comércio marítimo as feiras perdem suas funções de garantir a subsistência e o luxo das cidades feudais europeias. Porém o intercâmbio entre europeus, Império Romano do Oriente e muçulmanos devido as Cruzadas para ocupar Jerusalém propicia o surgimento de uma culinária rica na Europa. A evolução dos meios de transporte faz com que a atividade comercial que se estabelece nas vilas migre do formato de feiras para o de lojas permanentes.

Nos séculos XV e XVI, portugueses e espanhóis lançaram-se em busca de novos caminhos marítimos para a Ásia. Eram motivados pela busca de especiarias a preços mais vantajosos, de grande apreciação pelos europeus para apurar o sabor dos alimentos e para conservá-los e pelo interesse em descobrir novas fontes de ouro e de pedras preciosas. O resultado foi a descoberta da América em 1492, da Índia em 1498 e do Brasil em 1500. Assim como ocorreu o intercâmbio de produtos e receitas a tradição das feiras foi levada para essas colônias. Dessa forma as feiras livres brasileiras são heranças das feiras medievais portuguesas.

Quando portugueses chegaram ao Brasil, a economia dos índios era do tipo de subsistência. As trocas realizadas entre as tribos limitavam-se a artigos como pedra e plumas para enfeitar o corpo. Com a chegada dos portugueses o comércio entre portugueses e índios se diversificou e intensificou, tornando-se abusivo por parte dos portugueses a tal ponto que em 1534 D. Manuel I, rei de Portugal, ordenou que as relações comerciais ocorressem através dos povoadores da localidade. Segundo Mott (1976) para que fosse comercializado apenas o que os índios tivessem ou quisessem 
em 1548 D. João III ordena que fossem realizadas no mínimo um dia de feira nas vilas da Bahia. Ainda segundo o mesmo autor essa ordem não foi efetivada prontamente.

As hortaliças eram indispensáveis na alimentação do colonizador português. Entende-se por hortaliças todos os produtos plantados e colhidos em uma horta e os comumente utilizados pelos portugueses eram cebola, alho, coentro, hortelã, cravo, cominho, manjericão, alfavaca, couve, repolho, agrião, rábanos e nabo que foram trazidas de Portugal e plantadas no Brasil para o consumo diário. Segundo Cascudo (2004) os portugueses espalhavam sua horta pelo mundo levando-a onde iam.

O português manteve, quanto pôde no Brasil, a tradição natal das quintas, hortas e passais. Não podiam viver sem as hortaliças e semeou-as ao redor das casas, criando um cinturão verde dos mantimentos vegetais circundando vilas, como Olinda ou cidades como a do Salvador. (CASCUDO, 2004, p. 490)

Entre 1569 e 1789 os produtos que excediam às necessidades dos habitantes das roças, que circundavam as vilas e cidades, eram levados para as vilas e cidades e vendidos nas praças.

Em Salvador, em 1587, eram vendidas por habitantes das roças próximas às cidades frutas, hortaliças e mantimentos na praça da cidade. Com o aumento demográfico e diversificação econômica da Colônia, surge em 1732 a primeira feira, onde eram comercializados gado. "Provavelmente a primeira, senão uma das primeiras feiras a serem instituídas na colônia foi a de Capoame, situada na parte norte do Recôncavo Baiano". (MOTT, 1976, p. 85)

Para Mott (1976) essa é a primeira referência do que viriam a ser as feiras ou mercados no Brasil. Além do comércio na praça existiam nessa época as lojas que vendiam produtos importados e "as negras de tabuleiro" como eram chamadas as ambulantes. Produção e comércio predominantemente atividade do gênero feminino, as negras de tabuleiros eram, segundo o Instituto do Patrimônio Histórico e Artístico Nacional (2004), escravas libertas ou não que vendiam quitutes pelas ruas, praças, feiras e festas da cidade de Salvador.

[...] as primeiras feiras do Brasil Colônia, no século XVIII, desenvolveram-se da mesma forma que tantas outras na Europa. Elas localizavam-se em grandes pátios em frente a um marco nessas localidades, como uma igreja ou um largo, e rodeadas por inúmeras casas comerciais, sendo vendidos os produtos da região. (INSTITUTO DO PATRIMONIO HISTÓRICO E ARTÍSTICO NACIONAL, 2014) 
A feira de Capoame foi a mais importante feira de gado da Bahia durante o século XVIII segundo Costa (2014), sendo substituída pela feira de Santana em importância. Feira de Santana, cidade do Estado da Bahia, originou-se de uma fazenda por onde passavam boiadas em meados do século XIX, imagem 2, com destino a Salvador. Da movimentação surgiu uma pequena feira e em 1832 é criada a vila que hoje chama-se Feira de Santana. Feira de Santana passou então a ser o mais importante destino de todo o gado que ia do rio São Francisco para Salvador. Ressalta-se que a feira de Capoame existe até os dias atuais.

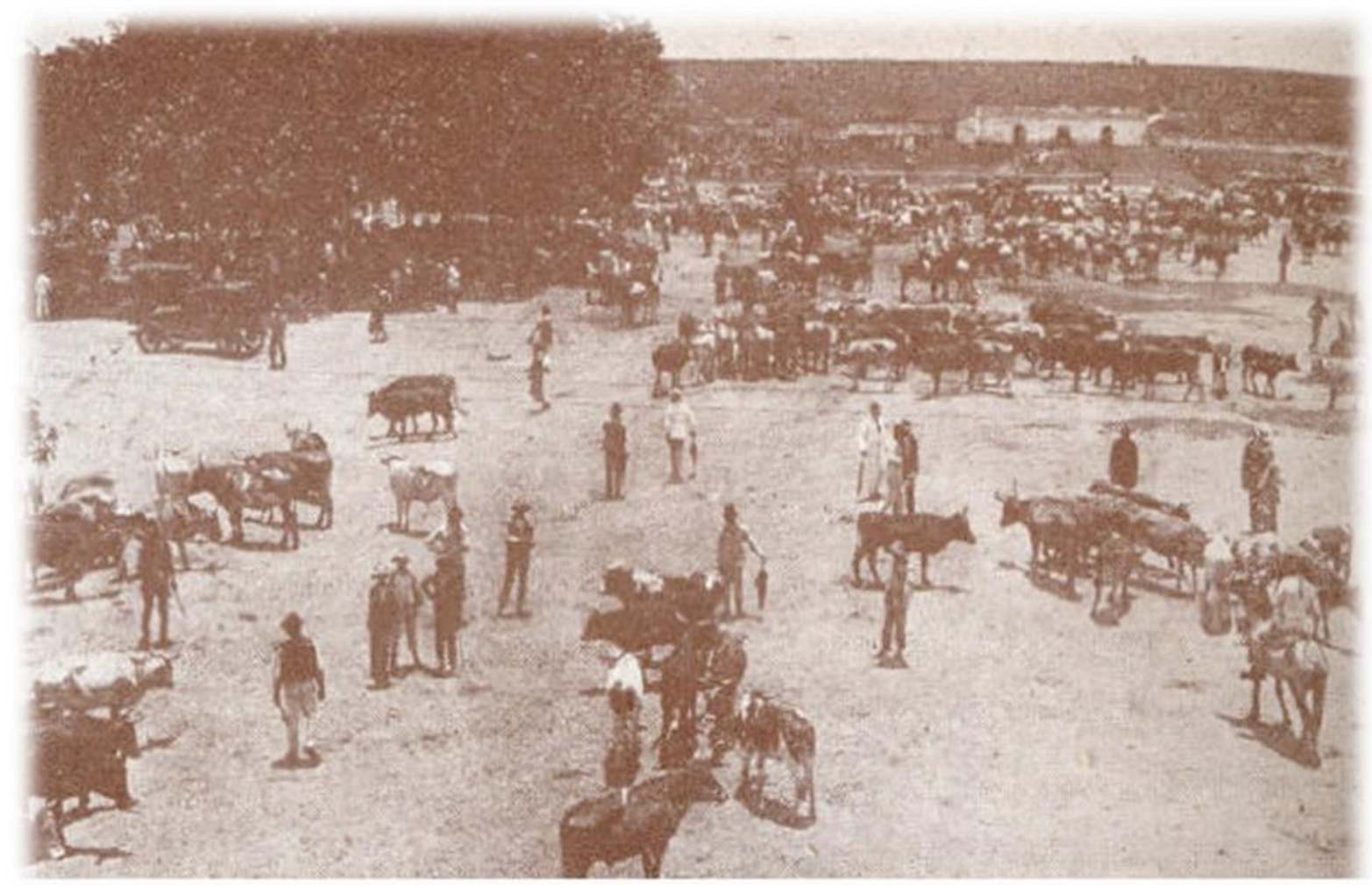

Imagem 2: Feira de Santana 1930

Fonte: COSTA, 2014.

Minas Gerais até metade do século XVIII era abastecida, inclusive por gênero primários, pela Europa, Bahia e São Paulo. Esta localidade estava mais preocupada com o extrativismo do que com a subsistência, pagando altos preços por insumos básicos. Poucos eram os que praticavam a produção de subsistência. Segundo Abdala (2007) o comércio ambulante, ou não, até o declínio da mineração, era caracterizado pela venda de alimentos feito predominantemente por mulheres. Negras vendiam seus quitutes (doces, bolos, queijo, leite e hortaliças) nas minas promovendo solidariedade entre a população pobre e escrava. 
A venda e o tabuleiro, enquanto partes do código da rua, foram espaços de relações comerciais e de satisfação de consumo. Ao mesmo tempo, tanto as reuniões de consumidores nesses dois espaços, como as festas, possibilitaram o estabelecimento de relações de intimidade, pessoalidade e solidariedade. No entanto, essas relações causavam incomodo às autoridades e provocavam inquietude nas elites, pelo ajuntamento que se efetivava entre as camadas populares. Esses encontros confrontavam a moral vigente, além de proporcionarem um potencial de contestação do status quo. (ABDALA, 2007, p.84)

Biscoitos, pé de moleque, pastel de milho ou trigo, peixe frito entre outros eram vendidos pelas "vendedeiras de doces", de sua maioria escravas, em seus tabuleiros nas escadarias da Igreja da Misericórdia, São Paulo, em 1703 segundo Martins (2003).

A feira da Vila De Nazareth (especializada em produtos agrícolas) com o comércio de grande quantidade de farinha, a feira de Pernambuco e Sergipe são ainda relatados por Mott (1976) para concluir que existiam feiras semanais destinadas a suprir as necessidades primárias e a feira-franca.

[...] naquela época existiam dois tipos diferentes de feira. A feira-mercado, realizando-se todos os sábados, com uma área de dominância mais restrita, destinada sobretudo ao abastecimento alimentar da população circunvizinha e a feira-franca, anual ou bianual, reunindo compradores e vendedores especialistas proveniente de regiões mais distantes, que comerciavam certos bens regionais, como o gado, por exemplo. (MOTT, 1976, p.89)

A economia mineira foi invertida em 1770 a fim de que a agricultura se sobrepusesse à mineração. As fazendas tornaram-se o núcleo da economia enquanto as cidades o núcleo político. Predominavam vilas pequenas compostas de rua única, igreja e venda de propriedade de fazendeiros que abasteciam cidades e vilas com carnes, farinha de mandioca, farinha de milho, café, cachaça entre outros. (ABDALA, 2007)

Em 1797 o então governador e capitão-general Antonio Manuel de Melo Castro e Mendonça, chamado de General Pilatos recebe uma ordem real para aquecer o comércio interno e externo da Capitania paulista. Em cumprimento a essa ordem estabelece-se a Feira de Pilatos no Campo da Luz, atual Avenida Tiradentes, em São Paulo, que assim como as feiras medievais europeias se organizava conforme o calendário de comemorações da igreja católica e do ciclo da agricultura. Habitantes da cidade e de vilas circunvizinhas foram chamados a participar da feira, comprando, vendendo ou permutando todo e qualquer gênero do país e de fora. Comerciantes 
estabelecidos na cidade e em vilas vizinhas, índios e mercadores armaram suas barracas ou utilizaram as providenciadas pelo General Pilatos (MARTINS, 2003). Como resultado da feira, General Pilatos relata em documento enviado ao Rei:

\begin{abstract}
Posso certificar a V. Ex. a , sem exageração, que ainda não vi uma Feira onde mais se ligasse a modéstia com a alegria do Povo, e que entretivesse com igual prazer todas as classes de pessoas, de forma que por gosto se podia andar passando por ela [...] (ANTONIO MANUEL DE MELO CASTRO E MENDONÇA apud MARTINS, 2003, p. 235).
\end{abstract}

As quitandas, "aglomeração de negras ao ar livre, acocoradas ou dispondo de tabuleiros, situadas em pontos preestabelecidos, para a venda de produtos de pequena lavoura, da pesca e da indústria doméstica" (MASCARENHAS, 2005, p.7), estavam presentes nas cidades brasileiras desde o início da colonização como maneira de sobrevivência de indivíduos pobres e formas populares de sociabilidade. No final do século XVIII o Rio de Janeiro possuía cerca de 180 barracas de quitandeiras, segundo Mascarenhas (2005). Em 1870 ainda segundo o mesmo autor a prefeitura do Rio de Janeiro decide, afim de retirar os vendedores ambulantes e as negras quitandeiras das ruas, ampliar a quantidade de mercados cobertos.

Em 1904 é criada oficialmente, no Rio de Janeiro, pelo decreto 994 as feiras ou mercados livres. Antes disso as feiras ocorriam de forma informal aos domingos e feriados ficando os mercados com a função de abastecer as cidades (MASCARENHAS, 2005).

Para Mascarenhas (2005) as feiras no Rio de Janeiro se espelharam nos centros urbanos europeus desempenhando então a função de organizar e controlar os espaços públicos da cidade promovendo a vivencia da cidade moderna e o abandono de comportamentos do período colonial. Possuíam maiores valores simbólicos do que de abastecimento.

Supomos que as feiras livres, por sua estética (o colorido, as linhas retas) e higiene (ao ar livre, exposição ao sol), sobressairiam em relação aos mercados cobertos, e assumiriam a condição de mais um dos espaços públicos festejados como triunfo da burguesia ascendente sobre a barbárie colonial. (MASCARENHAS, 2005, p. 11)

Nesse contexto as feiras foram criadas para fortalecer e simbolizar a modernidade urbana e sua ordem. 
Minas Gerais, do século XIX, conforme Abdala (2007), se caracterizava por concentrar a vida cotidiana nas fazendas ficando a rua com pouca atividade comercial alimentícia, uma vez que a fazenda se auto sustentava.

É inaugurado em 1901, em Belém do Pará, o mercado de peixe, que se junta ao que hoje chama-se Complexo Ver-o-Peso. Lá já existiam o Mercado Municipal e o mercado de carne (GUGLIELMO; FITTIPALDI, 2005).

De acordo com Feiras do Brasil (2014) o Calendário de Feiras do Brasil 2014 apresenta aproximadamente mil feiras e eventos internacionais, nacionais e regionais que ocorreram no país no ano de 2014.

O mercado de São José foi inaugurado em setembro de 1875 . Sua estrutura foi construída em ferro fundido produzidas em siderúrgicas francesas e importadas para o Brasil.

\begin{abstract}
$\mathrm{Na}$ sua concepção original, o pavilhão norte estava dividido em 64 compartimentos destinados para açougue e 128 para a venda de hortaliças, frutas, flores e outros gêneros. O pavilhão da banda sul teve seus 124 compartimentos divididos entre 64 compartimentos para açougues de vendas de vísceras e 60 para venda de secos e legumes. Ali havia, ainda, doze quadras, cada qual com 48 balcões, munidos com torneiras e mesas de mármore adequadas à venda de peixe, mantendo assim, a tradição do mercado no comércio de pescados, ali praticados desde o século XVIII. (LEAL, 2011, p. 27)
\end{abstract}

Hoje o mercado de São Jose de Recife/PE, Imagens 3 e 4, tombado como Monumento Nacional, registrado no Livro de Belas Artes em 1973, mantem a tradição de vender peixe, carne, charque, crustáceos além do artesanato, ervas, temperos, secos, hortifruti, artigos de umbanda, panelas entre outros em seus 757 pontos de comércio.

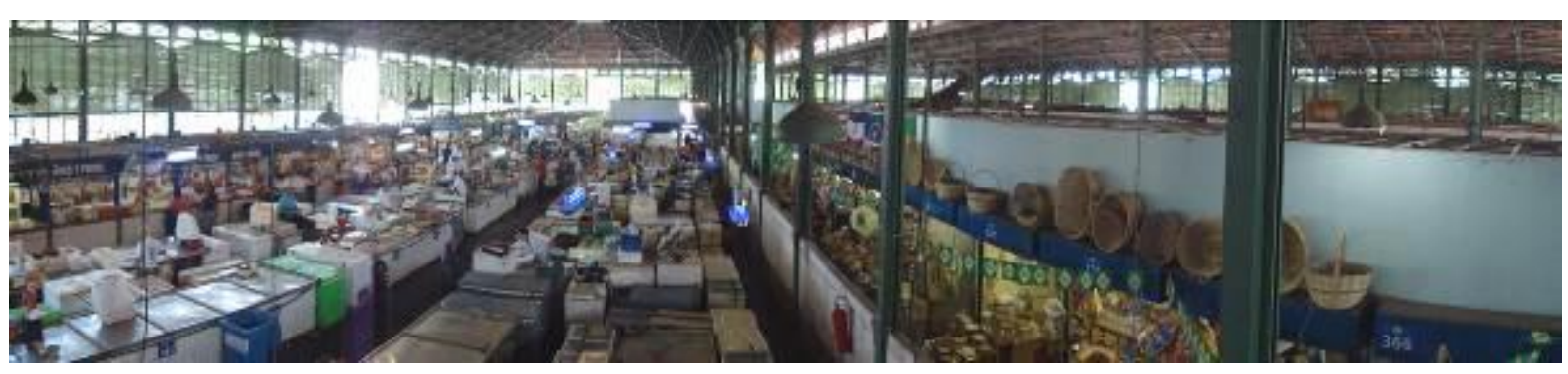

Imagem 3: Interior do mercado de São José - Recife/PE

Fonte: Imagem registrada pela pesquisadora em Julho de 2014. 


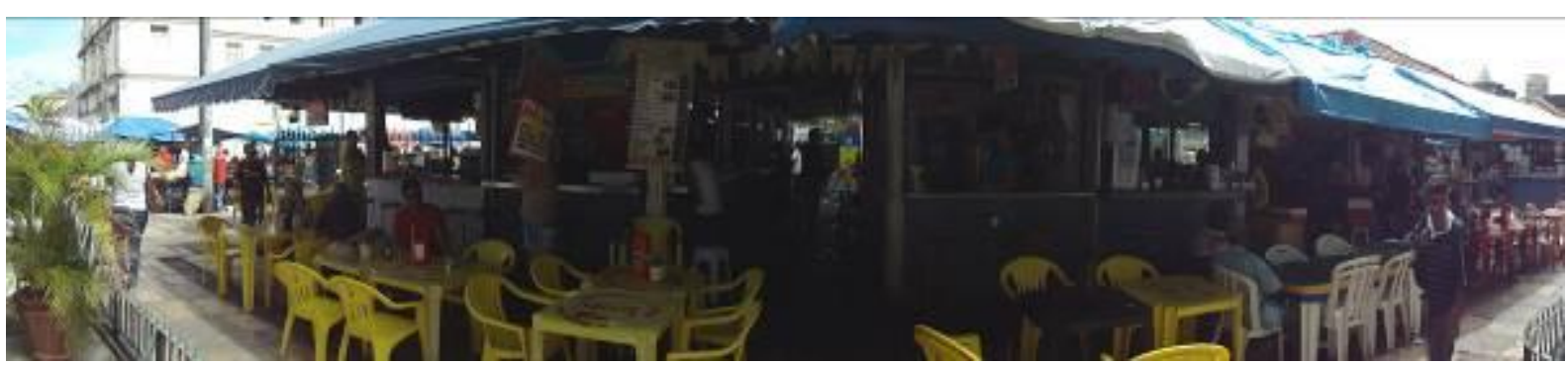

Imagem 4: Exterior do mercado de São José - Recife/PE

Fonte: Imagem registrada pela pesquisadora em Julho de 2014.

Complexo do Ver-o-Peso (Belém-Pará), Feira de Caruaru (CaruaruPernambuco), Feira Livre de Arapiraca (Arapiraca-Alagoas), Feira de São Joaquim (Salvador-Bahia), Mercado dos Tropeiros (Diamantina-Minas Gerais), Mercado Municipal Paulistano (São Paulo-São Paulo) são as seis referencias que Guglielmo e Fittipaldi (2005) escolheu para retratar o trabalho, realizada em 1980, sobre o universo cultural brasileiro.

O final do século XX apresenta um canal de comercialização dos gêneros alimentícios mais complexos em São Paulo, definido por Guimarães (1969) como uma trama que se inicia nas propriedades agrícolas, passam por intermediários e chegam ao consumidor nas metrópoles através dos estabelecimentos varejistas (mercearias, quitanda, supermercado, empório, peixaria, feiras, ambulantes, entre outros).

\begin{abstract}
É importantíssima a participação das feiras livres na distribuição de gêneros alimentícios ao consumidor, mesmo porque a sua clientela é das mais variadas, no tocante às classes sociais. Tal fato é possível porque há grandes diferenças nos artigos e nos preços encontrados de acordo com o dia em que se realiza, com a sua localização na cidade, e até com o horário em que é frequentada. Na feira são comercializados todos os gêneros alimentícios, industrializados ou não, exceto a carne fresca. É o tipo de comercio varejista que mais se aproxima do consumidor. (GUIMARÃES, 1969, p. 15)
\end{abstract}

Na década de 80, o Complexo do Ver-o-Peso em Belém - Pará, contava duas mil barracas em sua feira a céu aberto, onde segundo Guglielmo e Fittipaldi (2005, p.19) "se exprime o sabor local de uma realidade multicultural, feita de todas as gentes que lá chegaram e fizeram circular seus bens material e simbólico, seus conhecimentos, concepções e estilos de vida [...]".

No início do século XIX, em São Paulo, foi destinado às quitandeiras que vendessem verduras, legumes, frutas, leite e ovos na calçada da Rua das Casinhas (hoje Rua do Tesouro). Peixes eram vendidos nas calçadas da igreja da Ordem 
Terceira do Carmo. Cereais, canas e frutas vindas do Mosteiro de São Bento eram vendidos, em 1818, no Beco das Barbas, atual Ladeira do Porto Geral. Com a inauguração do Mercado da Rua 25 de Março, em 1867, e do Mercado de São José esses comércios foram lá concentrados (MARTINS, 2003).

Em São Paulo as feiras livres são regulamentadas, em 1914, e surge a primeira feira oficial, localizada no largo General Osorio. Segundo Sato (2012, p. 40), "nas duas ou três décadas que antecederam a instalação oficial das feiras livres, o comércio varejista de gêneros alimentícios em São Paulo era composto de mercados, quitandas, mercados caipiras, casinhas, armazém e mascates". Guimarães (1969) acrescenta que a oficialização das feiras livres nessa data apenas legitimou, pelo poder municipal, uma tradição que já era uma prática da cidade de São Paulo.

Em 1918 o movimento operário ocorrido, em São Paulo, reivindicava entre outros a implantação de feiras livres em todos os bairros da cidade, a fim de possibilitar acesso a gêneros alimentícios de primeiras necessidades pela população. O que inseriu nas feiras a presença de itens com preços inferiores aos praticados em outro comércio, pois esses itens passaram a ser isentos de impostos e taxas (SATO, 2012). Porém somente em 1948 essa reivindicação foi atendida e as feiras livres são expandidas se fazendo presente em cada bairro.

Dados da Prefeitura de São Paulo registram dezenas de leis, conforme Tabela 1 (p.30), que tratam das feiras-livres. A primeira delas é a Lei 3129, de 28 de dezembro de 1927, que determina que nas feiras livres só poderão ser vendidos gêneros alimentícios e flores naturais. Porém Guimarães (1969) ressalta que é o Decreto $n^{\circ}$ 5841, de 1964, que mais detalha a regulamentação das feiras livres quanto a localização espacial na cidade, organização interna, segurança higiênica-sanitária, requisitos para licença e obrigações dos feirantes incluindo tributos e multas.

No Município de São Paulo, segundo Guimarães (1969), em 1964 funcionam 452 feiras por semana localizadas em bairros de classe média alta e baixa, bairros antigos e novos o que permite constatar a importância das feiras para a cidade.

$\mathrm{Na}$ década de 60 os supermercados se firmam no cenário de abastecimento da população paulistana promovendo alterações no comércio dos gêneros alimentícios praticados até então. As feiras adquirem novos aspectos, passam então, a comercializar diversos tipos de produto, como os hortifrutigranjeiros, cereais, grãos, laticínios, frutas, pescados, comestíveis em conserva, roupas e calçados. 
Tabela 1 - Leis da cidade de São Paulo relacionadas às feiras-livres

\begin{tabular}{|c|c|c|}
\hline LEI No & PUBLICAÇÃO & EMENTA \\
\hline 3129 & $28 / 12 / 1927$ & $\begin{array}{l}\text { DETERMINA QUE NAS FEIRAS LIVRES SO PODERAO SER VENDIDOS GENEROS } \\
\text { ALIMENTICIOS E FLORES NATURAIS. }\end{array}$ \\
\hline 3380 & $10 / 9 / 1929$ & $\begin{array}{l}\text { PROIBE NAS FEIRAS LIVRES A VENDA DE ARTIGOS DE FABRICACAO ESTRANGEIRAS E } \\
\text { DAOUTRAS PROVIDENCIAS. }\end{array}$ \\
\hline 3702 & $10 / 8 / 1948$ & DISPOE SOBRE LOCALIZACAO DE FEIRAS LIVRES. \\
\hline 4326 & $30 / 12 / 1952$ & CRIA POSTOS DE FISCALIZACAO NAS FEIRAS LIVRES. \\
\hline 4479 & $3 / 6 / 1954$ & $\begin{array}{l}\text { DISPOE SOBRE A VENDA DE VISCERAS DE ANIMAIS DE CORTE, NAS FEIRAS LIVRES } \\
\text { DO MUNICIPIO DA CAPITAL, E DA OUTRAS PROVIDENCIAS. }\end{array}$ \\
\hline 6150 & $11 / 12 / 1962$ & $\begin{array}{l}\text { OBRIGA OS FEIRANTES A RENOVAREM ANUALMENTE A LICENCA MEDICA, E DA } \\
\text { OUTRAS PROVIDENCIAS. }\end{array}$ \\
\hline 7105 & $4 / 1 / 1968$ & $\begin{array}{l}\text { DISPOE SOBRE VENDA A VAREJO DE PRODUTOS ALIMENTICIOS DE ORIGEM ANIMAL, } \\
\text { E DAOUTRAS PROVIDENCIAS. }\end{array}$ \\
\hline 7341 & 10/9/1969 & $\begin{array}{l}\text { DISPOE SOBRE APREENSAO E REMOCAO DE PRODUTOS ALIMENTICIOS E ARTIGOS } \\
\text { DE UTILIDADE DOMESTICA QUE SE ENCONTRAM EM SITUACAO IRREGULAR DE } \\
\text { COMERCIO NAS VIAS OU LOGRADOUROS PUBLICOS, PROPRIOS MUNICIPAIS OU } \\
\text { FEIRAS-LIVRES, E DA OUTRAS PROVIDENCIAS. }\end{array}$ \\
\hline 8756 & $1 / 7 / 1978$ & $\begin{array}{l}\text { DISPOE SOBRE PERMISSAO PARA O PREPARO E A COMERCIALIZACAO DE PASTEIS } \\
\text { NAS FEIRAS-LIVRES DO MUNICIPIO E DA OUTRAS PROVIDENCIAS. }\end{array}$ \\
\hline 9676 & $7 / 1 / 1984$ & $\begin{array}{l}\text { DISPOE SOBRE PERMISSAO PARA A COMERCIALIZACAO DE MASSA PRONTA PARA } \\
\text { PASTEIS, PELOS FEIRANTES-PASTELEIROS, NA FEIRAS-LIVRES DO MUNICIPIO, E DA } \\
\text { OUTRAS PROVIDENCIAS. }\end{array}$ \\
\hline 11599 & $12 / 7 / 1994$ & $\begin{array}{l}\text { DISPOE QUE A VIGILANCIA NAS FEIRAS-LIVRES DO MUNICIPIO SEJA FEITA PELA } \\
\text { GUARDA METROPOLITANA. }\end{array}$ \\
\hline 11600 & $12 / 7 / 1994$ & DISPOE SOBRE A LOCALIZACAO DE FEIRAS LIVRES \\
\hline 11609 & 14/7/1994 & $\begin{array}{l}\text { DISPOE SOBRE A INSTALACAO DE PLACAS INFORMATIVAS NAS VIAS PUBLICAS DO } \\
\text { MUNICIPIO ONDE SE REALIZAM FEIRAS LIVRES. }\end{array}$ \\
\hline 11683 & $18 / 11 / 1994$ & $\begin{array}{l}\text { DISPOE SOBRE A PROIBICAO DE COMERCIALIZAR TODOS OS TIPOS DE CARNES, } \\
\text { PEIXESE AVES ABATIDAS EM BARRACAS DE FEIRAS-LIVRES DO MUNICIPIO DE SAO } \\
\text { PAULO QUENAO APRESENTAM AS CONDICOES MINIMAS DE HIGIENE E DA OUTRAS } \\
\text { PROVIDENCIAS. }\end{array}$ \\
\hline 12605 & 7/5/1998 & $\begin{array}{l}\text { DISPOE SOBRE A INSTALACAO DE CABINAS SANITARIAS PUBLICAS REMOVIVEIS, NAS } \\
\text { FEIRAS-LIVRES DE ALIMENTACAO, E DA OUTRAS PROVIDENCIAS. }\end{array}$ \\
\hline 12607 & $7 / 5 / 1998$ & $\begin{array}{l}\text { DISPOE SOBRE A PADRONIZACAO DE VESTIMENTA DOS FEIRANTES, E DA OUTRAS } \\
\text { PROVIDENCIAS. }\end{array}$ \\
\hline 13112 & $16 / 3 / 2001$ & $\begin{array}{l}\text { DISPOE SOBRE A AFIXACAO DE TABELA DEMONSTRATIVA DOS TAMANHOS MINIMOS } \\
\text { DOS PEIXES DESTINADOS AO COMERCIO NOS ESTABELECIMENTOS E BANCAS DE } \\
\text { FEIRA QUE COMERCIALIZEM O PRODUTO. }\end{array}$ \\
\hline 13783 & $13 / 2 / 2004$ & $\begin{array}{l}\text { DISPOE SOBRE SINALIZACAO DE ORIENTACAO TURISTICA NO MUNICIPIO DE SAO } \\
\text { PAULO, E DA OUTRAS PROVIDENCIAS. }\end{array}$ \\
\hline 13960 & $15 / 4 / 2005$ & $\begin{array}{l}\text { OFICIALIZA A FEIRA DE ARTE, ARTESANTO, ANTIGUIDADES, GASTRONOMIA, CULTURA } \\
\text { E LAZER DA PRACA DA REPUBLICA, NO MUNICIPIO DE SAO PAULO, E DA OUTRAS } \\
\text { PROVIDENCIAS. }\end{array}$ \\
\hline 14511 & $5 / 10 / 2007$ & $\begin{array}{l}\text { DISPOE SOBRE A INCLUSAO NO PROGRAMA DE PARCELAMENTO INCENTIVADO-PPI, } \\
\text { DE MULTAS APLICADAS AOS FEIRANTES, DECORRENTES DE INFRACAO A } \\
\text { LEGISLACAO DE POSTURAS MUNICIPAIS. }\end{array}$ \\
\hline 14731 & $21 / 5 / 2008$ & $\begin{array}{l}\text { INSTITUI A FEIRA MUNICIPAL DE ECONOMIA SOLIDARIA-ECOSOL E AS FEIRAS } \\
\text { REGIONAIS DE ECONOMIA SOLIDARIA DAS SUBPREFEITURAS-ECOSOL REGIONAIS, } \\
\text { NO MUNICIPIO DE SAO PAULO E DA OUTRAS PROVIDENCIAS. }\end{array}$ \\
\hline 15193 & $12 / 6 / 2010$ & $\begin{array}{l}\text { DISPOE SOBRE A SUBSTITUICAO DO TITULAR DA PERMISSAO DE USO PARA } \\
\text { EXERCICIO DO COMERCIO NAS FEIRAS LIVRES POR UM PREPOSTO E UM AUXILIAR, } \\
\text { NAS CONDICOES E PARA OS FINS QUE ESPECIFICA }\end{array}$ \\
\hline 15443 & 14/9/2011 & $\begin{array}{l}\text { ALTERA A LEI N. 14485, DE } 19 \text { DE JULHO DE 2007, COM A FINALIDADE DE INCLUIR NO } \\
\text { CALENDARIO OFICIAL DE EVENTOS A FEIRA DE ARTE, ARTESANATO, ANTIGUIDADES, } \\
\text { GASTRONOMIA, CULTURA E LAZER DA PRACA DA LIBERDADE, E DA OUTRAS } \\
\text { PROVIDENCIAS. (PL 579/08) }\end{array}$ \\
\hline
\end{tabular}

Fonte: Prefeitura de São Paulo, 2014.

A Feira Nacional de Indústria Têxtil inaugura em 1958 as feiras comerciais no Brasil. Entende-se esta tipologia de evento por: 
[...] instrumentos de comprovada eficácia comercial, por estabelecer o contato direto entre fabricante, comprador e usuário. Estes eventos são criados para a exposição pública e/ou comercialização de serviços e produtos industriais, técnicos ou científicos a um público específico. As feiras também são um forte elemento de sustentação de imagem da empresa e/ou produto em evidencia. (MARTINS, 2003, p. 50)

As feiras internacionais, originadas das feiras da Idade Média, proporcionam interação social, fomentam a economia e repercute no turismo, acrescenta Fuster (1971) que cita as feiras de Milão, Paris, Nova lorque, Bruxelas, Chicago e Seatle como exemplos de aglomeração de visitantes.

A evolução das baianas de tabuleiro permitiu seu reconhecimento ao ser registrado pelo Instituto do Patrimônio Histórico e Artístico Nacional em 2005 o Ofício das Baianas de Acarajé como bem cultural no Livro de Saberes. As hoje chamadas baianas do acarajé são as negras do tabuleiro do período colonial que vendiam comidas do universo religioso (candomblé). Ainda hoje essas mulheres utilizam o tabuleiro para comercializar o acarajé, abará, passarinha, cocada, pé de moleque entre outros quitutes (INSTITUTO DO PATRIMONIO HISTÓRICO E ARTÍSTICO NACIONAL, 2004).

A Feira de Caruaru, imagem 5, localizada no Parque 18 de Maio, Caruaru/PE ocupa $40.000 \mathrm{~m}^{2}$, atualmente o funcionamento é de segunda-feira ao sábado. Com origem no século XVIII "a feira cresceu juntamente com a cidade e foi um dos principais motores do seu desenvolvimento social e econômico" (INSTITUTO DO PATRIMONIO HISTÓRICO E ARTÍSTICO NACIONAL, 2014). Devido ao seu extenso tamanho a feira é dividida em segmentos: Frutas e Verduras, Carne, Feijão e Farinha, Troca-Troca, Passarinho (extinta), Flores, Panelas, Calçados, Roupas, Raízes e Ervas, Ferro Velho, Artesanato, Importados e Lanches (com comidas típicas, como: sarapatel, buchada, cuscuz, macaxeira, inhame, carne de bode, carne de sol, mungunzá, arroz doce, batata doce, xerém, coalhada, pamonha, canjica, entre outros). A Feira da Sulanca localiza-se no mesmo espaço e é conhecida por comercializa roupas a preços muito baixos. Já a Feira do Gado mudou-se há trinta anos para poucos metros do Matadouro Público (FEIRA DE CARUARU, 2014). Em 2006, a Feira de Caruaru foi registrada no IPHAN como Patrimônio Cultural Imaterial do Brasil no Livro de Registro de Lugares. 

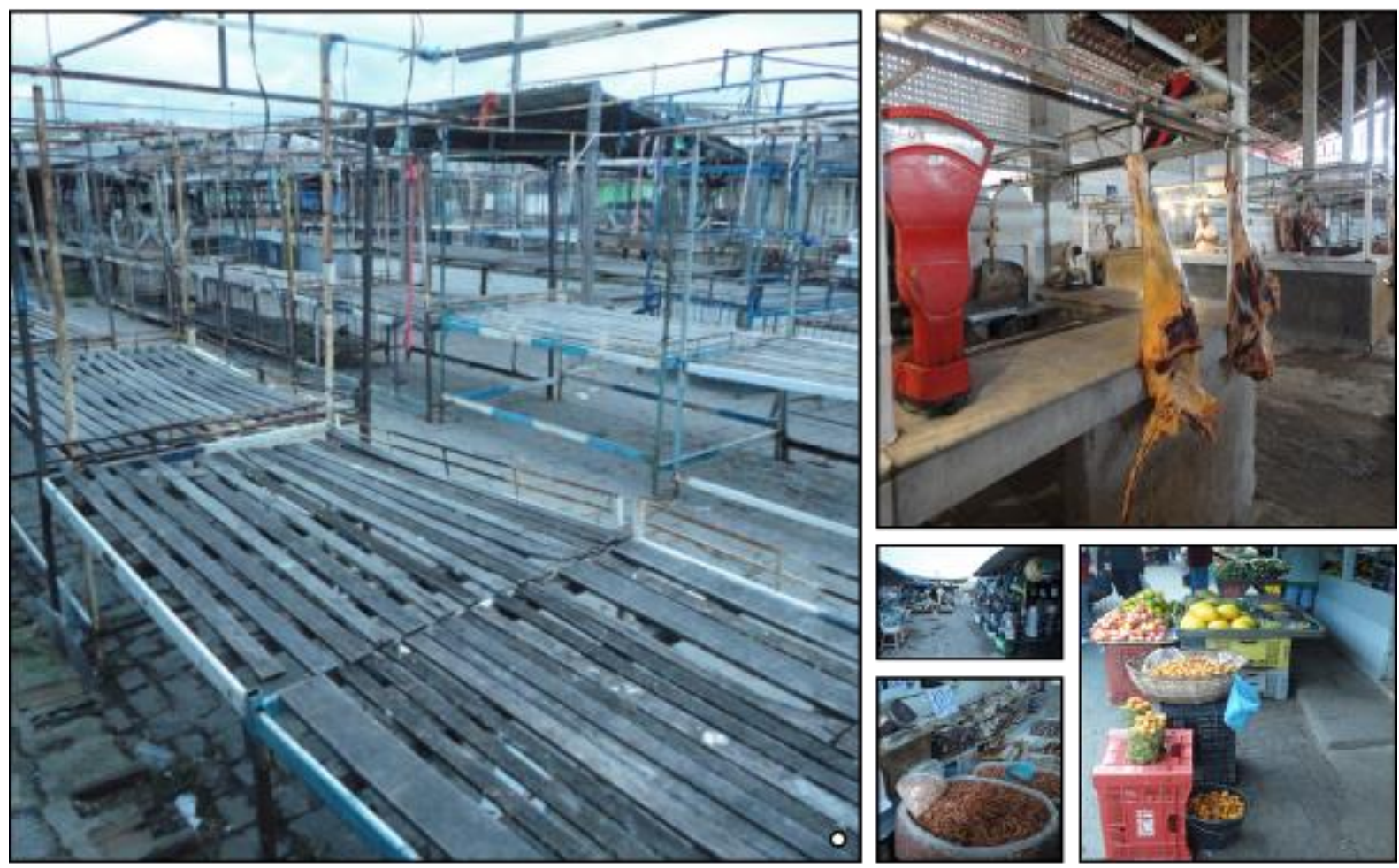

Imagem 5: Feira de Caruaru/PE

Fonte: Imagem registrada pela pesquisadora em Julho de 2014.

$\mathrm{Na}$ cidade do Rio de Janeiro em 2010 existiam cerca de cento e sessenta feiras segundo informação da Secretaria Municipal de Ordem Pública-SEOP (PREFEITURA DO RIO DE JANEIRO, 2014).

No Distrito Federal existem sessenta e quatro feiras livre e permanentes, segundo a Governo do Distrito Federal (2012).

Em 2014 há 873 feiras e 15 Mercados Municipais registradas em São Paulo sob a administração e fiscalização da Supervisão Geral de Abastecimento da Coordenação das Subprefeituras segundo Prefeitura de São Paulo (2014).

$\mathrm{Na}$ atualidade as feiras livres, permanentes, diárias, semanais, mensais ou anuais transcendem a função mais importante de sua origem, a de abastecer as cidades. Seja como forma de comercializar produtos da agricultura familiar, seja como possibilidade de emprego e renda, seja como forma de ocupação dos espaços públicos fato é que as feiras se fazem presentes nas grandes cidades até os dias de hoje. 


\title{
1.2 Dinâmica Comercial das Feiras de Rua as Lojas de Departamento
}

As feiras e mercados foram os primeiros pontos de encontro do processo de distribuição comercial. A atividade comercial se consolida pelo capitalismo mercantil e depois industrial. No século XIX a Revolução Industrial transformou a sociedade, pois com a cidade industrial o centro da produção gera centralidade de necessidades de serviços e suprimentos como de alimentos, vestuário, utensílios domésticos para a surgente população urbana. O fordismo e o taylorismo possibilitaram o aumento da produção e o surgimento de um novo mercado consumidor o qual com seus salários gera um círculo virtuoso de crescimento e concentração de trabalho-capital.

Assim, as feiras e mercados não comportaram a grande quantidade de produtos necessários à crescente demanda urbana, momento em que surge na Europa os grandes armazéns e nos Estados Unidos as lojas de departamento, porém, esse é um tipo de consumo para a população de maior poder aquisitivo. Trata-se de um consumo-sedução ou consumo-distração.

\begin{abstract}
Na primeira etapa, o formato predominante ainda era o de feiras e mercados e o das pequenas lojas que ofereciam uma gama variada de produtos, conhecidas como general store. Num segundo momento há segmentação maior e surge tanto feiras como mercados especializados em determinado tipo de produto, bem como as lojas que vendiam exclusivamente alimentos, conhecidas como grovery stores. Todavia é somente com o advento da Revolução Industrial e o crescimento das cidades que os formatos comerciais começam a se alterar, com os armazéns e os grandes armazéns vendendo maior variedade de produtos em um mesmo local. (JESUS, 2014, p. 46)
\end{abstract}

As lojas de departamento alteram a forma de consumir. Em 1838 o Le Bom Marche em Paris é inaugurado. No lugar do comerciante entram os funcionários, o preço fixo, a separação da burguesia das classes menos abastadas e o favorecimento da mulher no mercado consumidor. As lojas de departamento tornaram-se espaços de consumo fazendo com que a noção de entretenimento fosse associada a noção de consumo.

Desta forma, podemos afirmar que as lojas de departamento foram responsáveis pela transição de um modelo tradicional baseado na relação direta entre comerciante e o cliente final, para um modelo comercial moderno de lojas de varejo, no qual o cliente final não possui contato direto com o proprietário dos produtos. (JESUS, 2014, p.48) 
O período pós segunda guerra mundial dá origem aos mercados de massa e ao consumidor moderno, onde o esforço de venda concentrado no vendedor é substituído pela força das marcas e marketing.

Em 1912 surge nos Estados Unidos a primeira loja de auto-serviço. Em 1930 o primeiro supermercado é inaugurado em Nova lorque com o intuito de diminuir custos e consequentemente os preços dos produtos. Em 1940 já existiam oito mil supermercados nos Estados Unidos.

O primeiro shopping center dos Estados Unidos é inaugurado em 1916 na cidade de Chicago. A partir de 1950 os shoppings se consolidam e se especializam e outras formas comerciais se desenvolvem como o hipermercado, as lojas de conveniência, as vendas por telefone, as vending machines, os outlets e o comércio eletrônico.

Até o início da década de 1980 o aumento do poder de compra do trabalhador traz para o consumo de massa um número significativo de adeptos. Com esse aumento, é estabelecido o auto-serviço, o modismo e a obsolescência. Nesse contexto o consumo passa a ser um estilo de vida onde signos, e não mais produtos, são consumidos. Os objetos passam a ser mais produtores de sentido e identificação numa sociedade do hiperconsumo onde as identidades são adquiridas pelas maneiras de consumir.

\footnotetext{
Podemos dizer que os estilos de vida são formas de identidade coletiva e de fuga do anonimato social, por meio do consumo de bens carregados de significados culturais, como pode ser o caso de um espaço com características excepcionais. Por isso a importância de situar o consumo como 0 processo de mudança socialmente construído, que investe essencialmente no significado simbólico que os produtos, quaisquer que sejam, despertam nos consumidores. (JESUS, 2014, p. 26)
}

Novas formas de comercialização, que não a de massa, têm surgido a fim de atrair a atenção do consumidor. Essa nova forma aposta na oferta, para além de produtos, de experiências de vidas. Forma ainda, na qual o indivíduo pós-moderno se relaciona com a cidade. Assim a aquisição de produtos não deve ser compreendida apenas pela ótica econômica, mas também no contexto cultural.

A característica da sociedade pós-moderna é a cultura do consumo onde os signos são mais importantes que a utilidade do produto. O consumo molda as relações, a estetização da vida ganha importância e o marketing dita a moda com produtos que já nascem obsoletos. "Entretanto a descartabilidade crescente dos 
produtos tem gerado novas formas de consumo, mais preocupados e cientes dos impactos gerados pelo modelo atual de consumo indiscriminado" (JESUS, 2014, p. 30).

Surge então o consumo consciente, verde, ecológico, ético, colaborativo e sustentável em oposição ao consumismo. O verde é o que não agride o meio ambiente, utiliza material reciclável ou de manejo sustentável agregando valor ao seu produto "[...] buscando atrair consumidores de empreendimentos tradicionais - em especial pessoas com alto poder aquisitivo interessadas em um estilo de vida de baixo impacto ambiental [...]" (JESUS, 2014, p. 33). O consumo ético é pautado no comércio justo, socialmente justo e ambientalmente sustentável com respeito a cultura e promoção de qualidade de vida. O sustentável pauta-se no menor e melhor consumo e o colaborativo na reutilização, sem aquisição ou troca monetária, de produtos que são compartilhados e pertencentes a uma coletividade e não mais a um único indivíduo.

Várias formas de classificar o comercio varejista ${ }^{1}$ são propostas segundo Jesus (2014). Política de preços, filosofia de vendas, serviços prestados, imagem da loja, dimensão dos estabelecimentos, variedade dos artigos e qualidade dos produtos são algumas delas.

Segundo Kotler (1998) a classificação em lojas de varejo, varejo sem loja e organizações varejistas são as mais adequadas ao propósito do marketing. As lojas de varejo são divididas pelo mesmo autor em oito categorias: lojas de especialidade, lojas de departamento, supermercado, lojas de conveniência, lojas de desconto, lojas de liquidação, superlojas e showrooms de catálogos. Em relação aos níveis de serviços as categorias utilizadas são: varejo de auto-serviço, varejo de auto-seleção, varejo de serviço limitado e varejo de serviço completo.

A Secretaria de Comércio e Serviços (SCS) criada, no âmbito do Ministério do Desenvolvimento, Indústria e Comércio Exterior (MDIC) por meio do Decreto nำ5.532, de 6 de setembro de 2005, utiliza as categorias agrupadas por atividades, conforme Tabela 2.

\footnotetext{
${ }^{1} \mathrm{O}$ varejo inclui todas as atividades envolvidas na venda de bens e serviços diretamente aos consumidores finais para uso pessoal. (KOTLER, 1998, p. 493)
} 
Tabela 2: Grupo de Atividades Comércio e Serviços no Brasil

\begin{tabular}{|c|c|}
\hline $\begin{array}{l}\text { Comércio } \\
\text { Combustíveis e lubrificantes }\end{array}$ & $\begin{array}{l}\text { Serviços } \\
\text { Prestados às famílias: alojamento e alimentação }\end{array}$ \\
\hline $\begin{array}{l}\text { Supermercados, Hipermercados, produtos } \\
\text { alimentícios, bebidas e fumo }\end{array}$ & Informação e comunicação \\
\hline Tecidos, vestuário e calçados & Profissionais, administrativos e complementares \\
\hline Móveis e eletrodomésticos & Transportes, e auxiliares dos transportes e correio \\
\hline $\begin{array}{l}\text { Artigos farmacêuticos, médicos, } \\
\text { Ortopédicos, de perfumaria e cosméticos }\end{array}$ & Outros serviços \\
\hline \multicolumn{2}{|l|}{$\begin{array}{l}\text { Equipamentos e materiais para escritório, } \\
\text { Informática e de comunicação }\end{array}$} \\
\hline \multicolumn{2}{|l|}{ Livros, jornais, revistas e papelaria } \\
\hline \multicolumn{2}{|l|}{ Outros artigos de uso pessoal e doméstico } \\
\hline Veículos e motocicletas, partes e peças & \\
\hline
\end{tabular}

Fonte: Ministério do Desenvolvimento, Indústria e Comércio Exterior (2014)

O Banco Nacional de Desenvolvimento (2000) classifica o comércio varejista em com loja e sem loja. No que se refere ao lojista afirma que a segmentação considera diversas formas de classificação tais como as demonstradas na Tabela 3. As cadeias, atualmente operam como franquias, ou seja, o comerciante, mediante pagamento de porcentagem geralmente do lucro, opera a loja utilizando marca, produto e serviços padronizados. As cadeias e franquias podem ser classificadas em locais, regionais e nacionais e em pequenas, médias e grandes.

Tabela 3: Comércio Varejista com Loja

\begin{tabular}{c|l|l|l}
\hline Área & \multicolumn{1}{|c|}{ Número de lojas } & \multicolumn{1}{|c}{ Localização } & Deslocamento \\
\hline Pequeno & Independente & Loja de rua & Mensal \\
\hline Médio & Cadeia & Galerias & Conveniência \\
\hline Grande & & Centro comercial & Rotina \\
\hline & & Strip centers (junto a grandes lojas) & Aventura \\
\hline & & Shopping centers &
\end{tabular}

Fonte: Banco Nacional de Desenvolvimento (2000).

Ainda, produto vendido, especialização, atendimento, serviços agregados, preço, proximidade do consumidor, mix de mercadorias e número de itens são variáveis utilizadas se referir ao setor de comércio varejista como: especializado x não 
especializado; alimentos $x$ não alimentos; seleção assistida $x$ auto-serviço; convencional $\mathrm{x}$ de desconto; vizinhança $\mathrm{x}$ não vizinhança; e soft line $\mathrm{x}$ full line. (BANCO NACIONAL DE DESENVOLVIMENTO, 2000).

Tendo como base a filosofia de vendas Jesus (2014) as classifica como itinerante (o vendedor se desloca em intervalos regulares para os mesmos lugares), loja tradicional (as características do vendedor chegam a ser mais importantes que o produto em si), venda por livre serviço (acesso direto consumidor produto), domicílio (vendedor vai até à residência ou trabalho do comprador), correspondência, distribuidor automático e eletrônico a distância.

Já a classificação do estabelecimento apresenta três tipos distintos: centro comercial não planejado, centro comercial planejado e lojas isoladas. O centro comercial não planejado é desencadeado espontaneamente, geralmente localizado em áreas centrais do bairro ou da cidade com predomínio do comércio tradicional ou lojas de rua. Existe ainda o centro comercial planejado (shopping centers, hipermercados entre outros) e as lojas isoladas que não contam com outras lojas próximas por exercer forte atração por si só (JESUS, 2014).

As novas formas de comércio varejista estão constantemente ameaçando as formas tradicionais, porém, segundo Kotler (1998) os ciclos de vida das novas formas de varejo estão cada vez mais curtos, atingindo seu declínio rapidamente. A concorrência entre cadeia de lojas e lojas independentes menores está acirrada. De um lado o poder de compra em quantidade possibilita preços inferiores às cadeias de lojas além da estrutura física possibilitar maior conforto. Porém a outra ponta nem sempre se prejudica com as grandes lojas.

\footnotetext{
Muitos pequenos varejistas estão prosperando. Esses lojistas independentes estão constatando que tamanho e poder de marketing, frequentemente, não condizem com o toque pessoal que as pequenas lojas ou os nichos de especialidade podem oferecer a uma base de consumidores fiéis. (KOTLER, 1998, p. 508)
}

Vale ressaltar que o comércio varejista, seja pequeno ou grande, está em constante mutação e adaptação para assegurar o poder competitivo no atendimento das demandas dos clientes. Em relação as alterações nas demandas Jesus (2014, p. 70) destaca quatro fatores presente na maioria delas: "a experiência de compra, a conveniência, o uso intenso de tecnologia de informação e o uso de redes sociais como suporte do consumidor". 
A medida que uma forma de consumo tradicional ou habito satura, outras tomam seu lugar ou necessitam de reestruturação. As alterações urbanas e sociais fazem segundo Kotler (1998) ressurgir estabelecimentos que além de produtos e serviços oferecem espaço de convivência e encontro. Motivadas pelas mesmas alterações urbanas e sociais o comércio de vizinhança vem crescendo, se enquadrando ainda no fator conveniência citada por Jesus (2014).

Em relação aos muitos formatos do comércio varejista, o Banco Nacional de Desenvolvimento (2000) afirma que a concorrência não acontece apenas entre formatos de lojas iguais e que não existe uma categoria que impere sobre as outras. Todas as formas de comércio são válidas, haja vista que cada uma alcança um segmento de mercado com inúmeras oportunidades de negócios. O que merece maior atenção é a eficiência do negócio, a concentração nos pontos fortes, na razão de ser do estabelecimento e no público-alvo.

\subsection{O Distrito Federal e as Feiras}

Brasília foi idealizada no local onde é geograficamente, para promover a integração e desenvolvimento das regiões interioranas despovoadas e com poucos recursos. Ainda, foi planejada para ser uma cidade basicamente administrativa com as características de Distrito Federal, território neutro e equidistante das Unidades Federativas sem demandas municipais ou estaduais. Seu propósito era unificar o país buscando seu desenvolvimento.

A proposta de se construir uma cidade para ser a Capital do Brasil se baseou, segundo Vasconcelos (1960) nas experiência vividas em Antióquia (298 a.C. - beira do Rio Orante, na Turquia.), Bizâncio (330 d.C. - Constantinopla, hoje Istambul), DurXaruquim (713 d.C. - Capital do Reino da Assíria, Antiga Ásia), Petersburgo (1782, hoje Leningrado), Madri (1783, Espanha), Washington, (1887, Estados Unidos), Ottawa (1865, Canadá), Camberra (1927, Austrália) e outras cidades construídas para serem, assim como Brasília, Capital.

A Capital de um país "É uma comunidade sem fronteiras da qual é cidadão não apenas o domiciliado, porém todo o nacional" (VASCONCELOS, 1960, p. 21). 
A Constituição Brasileira de 1891 já determinava a mudança da Capital Federal para o Planalto Central, interior do país, apenas não se sabia exatamente para onde.

Brasília era, antes de tudo, uma necessidade. Urgia construí-la no menor prazo possível, para recuperar centenas de anos em que a civilização brasileira se concentrou somente na orla marítima, deixando à própria sorte o resto de seu imenso território. (SILVA, 1985, p.15)

Em 1882 o Marechal Floriano Peixoto expressa ao Congresso Nacional a necessidade da mudança da Capital para o Planalto Central. Em maio do mesmo ano a Comissão Exploradora do Planalto Central do Brasil, dirigida por Luiz Cruls foi organizada.

No dia 9 de junho de 1882, a Comissão partiu do Rio de Janeiro diretamente para Uberaba, ponto terminal dos trilhos da Estrada de Ferro Mogiana. De Uberaba, a cavalo, os membros da Comissão se dirigiram a Pirenópolis, onde chegaram a primeiro de agosto. De Pirenópolis, a Comissão se dividiu em dois grupos: um deveria seguir caminho direto até a cidade de Formosa; o outro, que atingiria Formosa, seguiria linha quebrada, passando pela cidade de Santa Luzia (hoje Luziânia). (SILVA, 1985, p. 51)

No final de 1884 o Relatório Final de Cruls é apresentado². Após muitas controvérsias, outros estudos e outras Comissões (a chefiada pelo General Poli Coelho e a chefiada por Donald Belcher) foram realizadas para definir a melhor localização da nova Capital. O Relatório Belcher dividiu o retângulo de Cruls em cinco sítios nomeados de Castanho, Verde, Vermelho, Amarelo e Azul que foram minunciosamente estudados. Em 1955 é escolhido o Sítio Castanho, com área aproximada de $5.850 \mathrm{~km}^{2}$. Em maio do mesmo ano foi fincada uma cruz de madeira no ponto mais alto do sítio, onde hoje chama-se Praça do Cruzeiro, que segundo Silva (1985) é a verdadeira pedra fundamental da cidade.

O concurso para a escolha do melhor projeto para a construção do Plano Piloto e a constituição da Companhia Urbanizadora da Nova Capital do Brasil NOVACAP ocorrem em setembro de 1956.

A Comissão de Planejamento da Construção e da Mudança da Capital Federal estava ciente que com o início da construção muitos nordestinos, goianos e

\footnotetext{
2 "Nós sabemos que a área demarcada por Cruls era um retângulo de 160 km, por 90 km, situados entre as latitudes

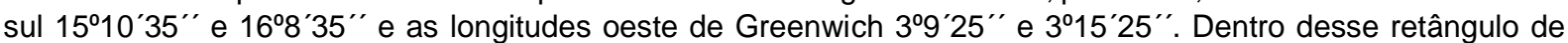
Cruls estava a Serra dos Pirineus, as cidades de Planaltina e Corumbá de Goiás, ficando junto de seus limites, mas do lado de fora, as cidades de Luziânia e Formosa" (SILVA, 1985, p. 68).
} 
mineiros buscariam na nova Capital maiores e melhores chances de emprego e condição de vida.

\begin{abstract}
Nosso pensamento era criar condições favoráveis nesses municípios vizinhos $^{3}$ (colônias agrícolas, pequenas indústrias), dotando-os também de assistência médica e educacional condigna, e preparando-os para receberem esse excesso de migrantes, a fim de que Brasília fosse o que ela deveria ser na realidade: a pequena cidade de 500.000 habitantes, onde os Três Poderes se instalassem, com aquela população adjetiva necessária à população substantiva. (SILVA, 1985, p. 124)
\end{abstract}

Planejada para existir durante a construção de Brasília, entre 1956 e 1960, a Cidade Livre, atual Núcleo Bandeirante ${ }^{4}$, dava suporte, segundo Vasconcelos (1988), aos trabalhadores e as obras da construção, exercendo as funções de centro do comércio e recepção dos migrantes.

\begin{abstract}
Abrigava, em seus hotéis de madeira, a quem chegasse; supria, a todos, de gêneros e materiais básicos, na dupla função de feira e almoxarifado; saciava a sede e a fome em seus bares e em seus restaurantes rústicos, onde eram servidos até pratos da cozinha internacional, acolhia e oferecia entretenimento, lazer e conforto espiritual à grande massa humana de engenheiros, arquitetos, técnicos e trabalhadores braçais que participavam da epopeia da construção da nova Capital do Brasil no Planalto de Goiás. (VASCONCELOS, 1988, p. 101)
\end{abstract}

Para a ocupação a NOVACAP, encarregada das obras, arrendou por quatro anos os lotes destinados ao comércio, as indústrias e as atividades de serviço com incentivos fiscais, ou seja, livres de impostos e taxas. Porém os incentivos não foram suficientes para atrair interessado em ocupar e desempenhar tais atividades o que levou o então diretor na NOVACAP, Bernardo Sayão a difundir a notícia em Anápolis, Ceres e Triangulo Mineiro. Em dezembro de 1956 chegaram os primeiros interessados que construíram em madeira seus estabelecimentos. Um restaurante, um hotel com seis cômodos, duas padarias e um açougue. O restaurante e umas das padarias era de propriedade de Victor Pellechia e o hotel de José Borges Paniago (VASCONCELOS, 1988).

Victor Pellechia, imagem 6, imigrante de origem italiana, instalou o restaurante, primeiro estabelecimento comercial, à beira do Córrego Vicente Pires na

\footnotetext{
${ }^{3}$ Silva refere-se a Formosa, Luziânia, Corumbá de Goiás, Cristalina, Planaltina e Unaí

${ }^{4}$ Segundo Vasconcelos (1988) a Cidade Livre era chamada de núcleo pioneiro pelos técnicos da NOVACAP e seus moradores percebiam tal referência com simpatia, o que não ocorria com o nome Cidade Livre, que julgavam pejorativo. Bandeirante era a palavra utilizada por Juscelino Kubitschek para se referir aos que trabalhavam nas obras de Brasília, assim Cidade Livre foi designada Núcleo Bandeirante.
} 
Cidade Livre em novembro de 1956. Ao lado do restaurante construiu também em madeira uma padaria e tempos depois construiu o mercado Diamantina na Avenida Central (VASCONCELOS, 1992).

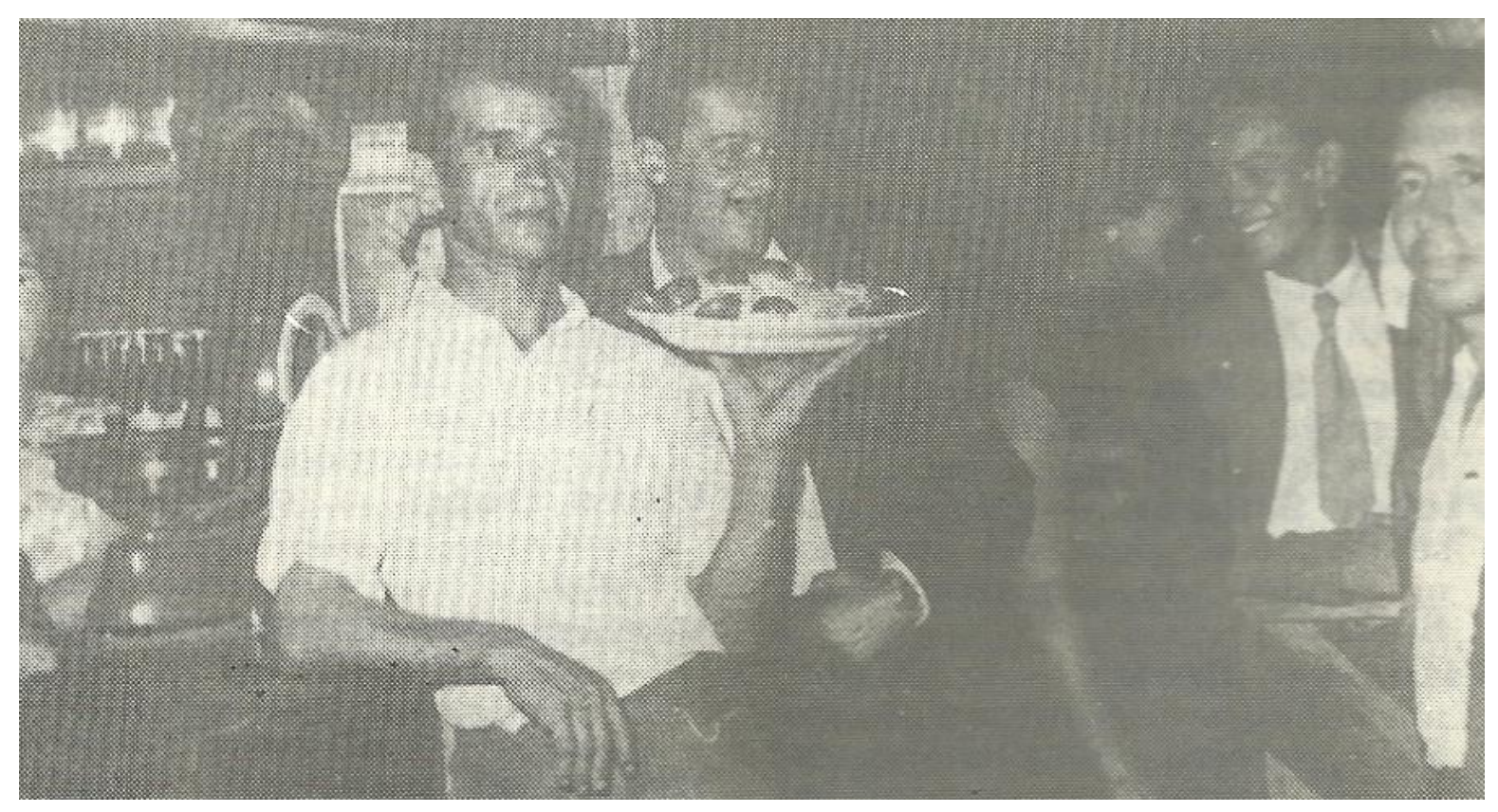

Imagem 6: Victor Pellechia

Fonte: Vasconcelos, 1992, p. 983.

Em fevereiro de 1957 a nova Capital já havia se transformado em um canteiro de obras com cerca de três mil homens trabalhando na construção do aeroporto, escritórios e depósitos da NOVACAP, casas coletivas para operários, estradas entre outros. A imagem 7 ilustra a construção da cidade.

Em março do mesmo ano o projeto de Lucio Costa é escolhido por integrar a concepção administrativa da cidade à vida urbana.

Ela deve ser concebida não como um simples organismo capaz de preencher, satisfatoriamente, sem esforço, as funções vitais próprias de uma cidade moderna qualquer, não apenas como urbs, mas como civitas, possuidora dos atributos inerentes a uma capital. E para tanto, a condição primeira é acharse o urbanista imbuído de uma certa dignidade e nobreza de intenção, porquanto desta atitude fundamental decorrem a ordenação e o senso de convivência e medida capazes de conferir ao conjunto projetado o desejável caráter monumental. Monumental não no sentido de ostentação, mas no sentido de expressão palpável, por assim dizer, consciente, aquilo que vale e significa. Cidade planejada para o trabalho ordenado e eficiente, mas ao mesmo tempo cidade viva e aprazível, própria ao devaneio e à especulação intelectual, capaz de tornar-se com o tempo, além de centro de Governo e administração, num foco de cultura das mais lúcidas do País. (LUCIO COSTA apud SILVA 1985, p. 161) 
Em julho de 1957 já existiam mais de cem construções e mais de mil pessoas desempenhavam alguma atividade na Cidade Livre. O aumento populacional nos canteiros de obras e as necessidades destes pressionavam o crescimento da Cidade Livre que ao final de 1957 possuía uma população de cerca de duas mil pessoas e as atividades desenvolvidas eram diversificadas: zona boêmia, igrejas, bares, restaurantes, quitandas, armazéns, fábrica de picolé entre outros segundo Vasconcelos (1988). Nesse contexto, no ano da inauguração de Brasília o já denominado Núcleo Bandeirante possuía uma população de cerca de vinte mil pessoas.

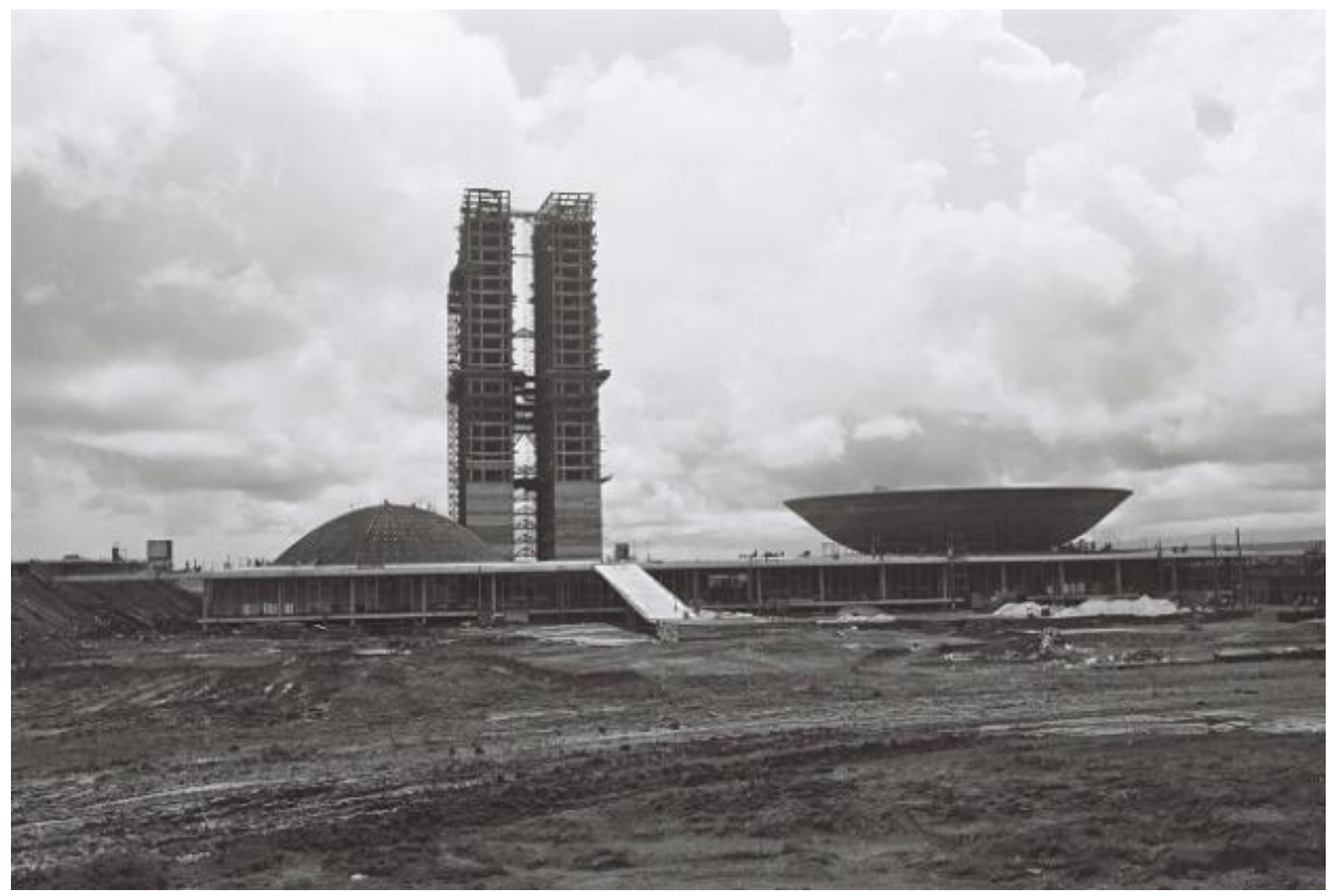

Imagem 7: Brasília em construção

Fonte: Câmara dos Deputados, 2015.

Em 1959 Brasília já possuía cerca de 60.000 habitantes que com grande afinco, determinação e trabalho inauguram a nova Capital em 21 de abril de 1960. "Inicia-se uma nova fase. Termina a epopeia e começa o cotidiano" (SILVA, 1985, p. 217).

Antes mesmo de sua inauguração "favelados" foram removidos pela NOVACAP para as então chamadas cidades-satélites. De acordo com Silva (1985) a 
Candangolândia fora criada em outubro de 1956 como primeiro núcleo habitacional para resolver "problemas sociais".

Taguatinga recebeu, conforme Vasconcelos (1988), no início de 1958, milhares de migrantes que haviam se instalado na Vila Sarah Kubitschek, próximo à Cidade Livre. Em 1961, o núcleo pioneiro administrativo, populacional e de comércio reivindicou sua fixação e constituição como cidade-satélite, a exemplo de Taguatinga e Gama, que foi atendida por força de lei, passando a se chamar Núcleo Bandeirante.

Acampamentos como o da Sacolândia (abrigos feitos de saco de cimento) e da Vila Amaury, imagem 8, foram transferidos, segundo Silva (1985), rapidamente. Mais de vinte mil pessoas em vinte dias foram removidas para as cidades satélites.

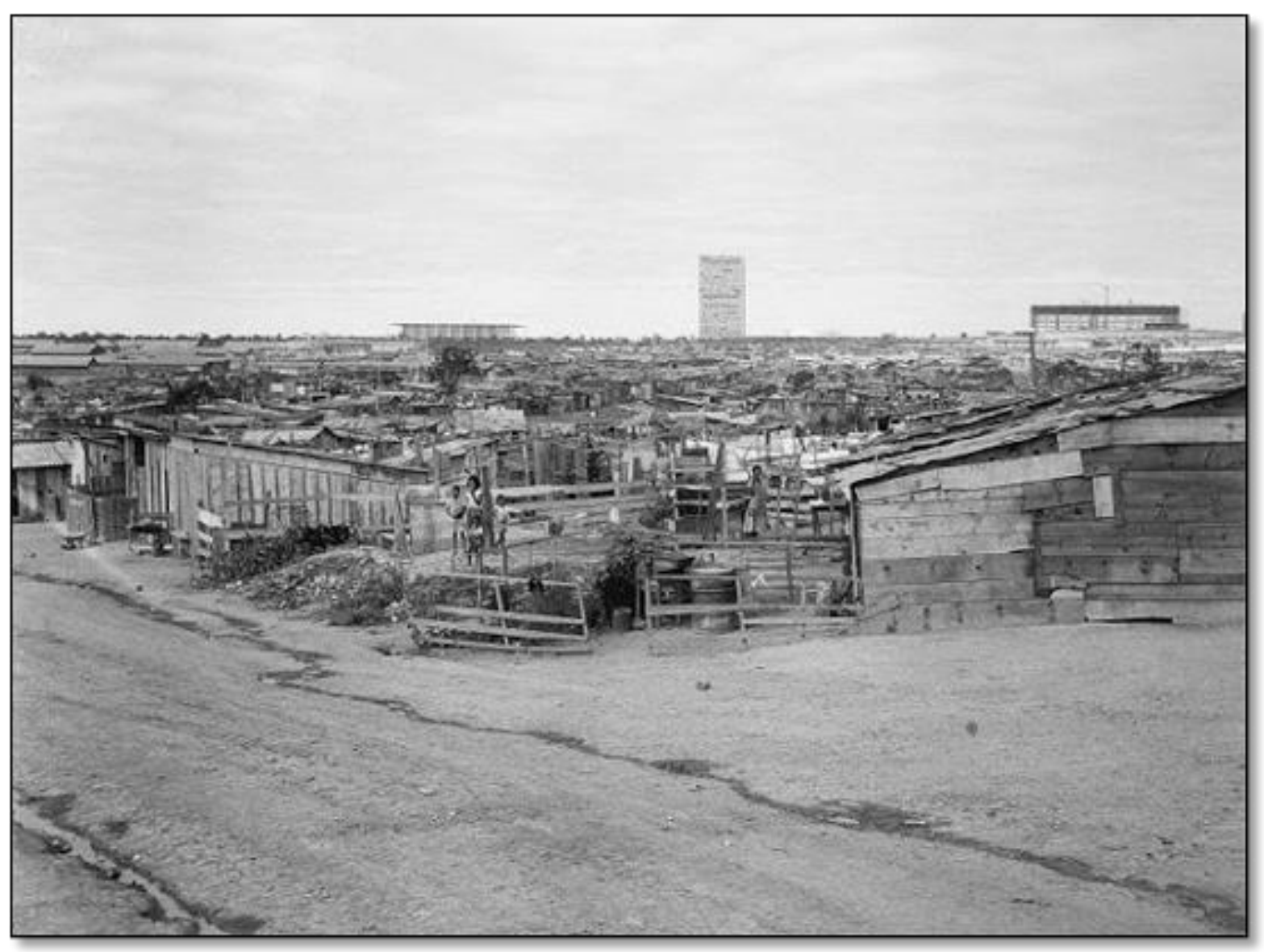

Imagem 8: Vila Amaury 1959, atual Lago Paranoá Fonte: Manhães, 2010. 
A cada dia que passava, a Novacap, através da nossa Diretoria, cuidava com desvelo dos problemas sociais. Estávamos presentes e atentos na transferência das favelas do Plano Piloto para as cidades satélites. Mais tarde, com o enchimento do lago, fizemos a transferência de milhares de pessoas da Vila Amaury para os novos lotes das cidades satélites de Sobradinho e Taguatinga, a que se deu o nome de Operação Caramujo, pelo fato de os favelados carregarem nas costas os seus pertences. (SILVA, 1985, p. 266)

Segundo Silva (1985) desde a escolha da localização do sítio a questão do solo propício e possível para a produção agrícola foi de importância significativa uma vez que existia a preocupação de abastecimento de uma cidade que se construiu no meio do nada e onde não se desejava incorrer em problemas dessa ordem. A Novacap através do Departamento de Terras e Agricultura fomentou a produção agrícola, animal e o florestamento e reflorestamento do Distrito Federal. O Plano de Abastecimento de Brasília estava estruturado em 1958 onde cada Região Agrícola deveria ter um mercado, chamado de Mercado do Produtor que deveria constituir uma Unidade Socioeconômica Rural, um Centro de Abastecimento, localizado no perímetro urbano e Supermercados que distribuiriam a produção.

Em 1959 já existiam 30.000 hectares, divididas em Regiões Agrícolas, destinados aos agricultores que chegavam a Brasília.

As unidades Socioeconômicas Rurais, localizadas nas bordas da faixa Sanitária, serviriam aos loteamentos rurais previstos e teriam como tarefa: a organização dos produtores, o fomento e assistência técnica à produção, o financiamento ao lavrador e, além dessas medidas de caráter técnicoeconômico, responderiam pela ativação social, ministrando aos seus congregados assistência religiosa, recreação, atividades esportivas e ainda estimulando as decisões associativas e cooperativas. (SILVA, 1985, p. 260)

O valor exato nunca será conhecido porém segundo Cataldo e Ramos (2010) o ex-Ministro Ronaldo Costa Couto estimou em centro e trinta bilhões de dólares o montante que construiu Brasília. "A profecia de que Brasília promoveria a interiorização do desenvolvimento brasileiro, como tantas vezes se reiterou na época de sua fundação, cumpriu-se" (CATALDO; RAMOS, 2010, p. 78).

Em 1970 quase 100 mil pessoas viviam, segundo Vasconcelos (1988), em condições sub-humanas no Plano Piloto. Eram famílias de todo o país que chegavam em busca de melhores condições de vida e acabavam por utilizar áreas públicas para construir suas moradias por falta de opção. As cidades satélites não eram atraentes por serem distantes do Plano Piloto e não estarem prontas para recebe-los. 
A explosão demográfica na recém criada Capital resultou na ocupação de áreas públicas no Plano Piloto. A principal foi a invasão IAPE localizada próxima a Cidade Livre. Segundo Vasconcelos (1988) eram 80 mil favelados, uma verdadeira cidade.

Os migrantes que vieram para Brasília encontraram melhores condições de vida que em suas terras natais, porém a falta de emprego marginalizou-os. Os empregos públicos chegam ao seu esgotamento e faz-se necessário construir oportunidades na esfera privada. Como não se desejam indústrias, resta o terceiro setor.

De quem nasceu e cresceu sob a utopia coletiva de estar na "capital da esperança" restam as cicatrizes ou a rebeldia sobre uma ética e estética de lugar que se transformou em algo que não se imaginou.

Tudo em Brasília era novo, assim, poderia ser único, uma vez que as crianças vivenciavam a construção comunitária, em que cada um era originário de um local do país. O preconceito com o diferente deixou de existir por existir a necessidade uns dos outros a fim de fundar um espaço de convivência.

Quando os tanques de guerra se instalaram na cidade, ela ainda era pequena, todos viviam próximos, compartilhavam os espaços (clubes, restaurantes, igrejas, cinema), percorriam o mesmo caminho, mas logo a desconfiança se instalou devido às divisões ideológicas e políticas (CATALDO; RAMOS, 2010).

Desde 1969 a Campanha de Erradicação de Invasores - CEI trabalhava para retirar os invasores do Plano Piloto. "Era necessário manter o poder distante dos grandes centros, consolidando a cidade, agora como ilha de segurança" (CATALDO; RAMOS, 2010, p. 60). A proposta da Campanha era inovadora. Pretendia-se, segundo Vasconcelos (1988), não apenas construir habitações, mas oferecer equipamentos comunitários básicos.

O proposito maior era o de integrar uma população marginalizada dentro de um novo tipo de comunidade organizada, assegurando-se a ela melhores condições de vida e bem estar social, e criando-se, nela, com o tempo, uma elevação do nível de aspiração social e intelectual. (VASCONCELOS, 1988, p. 61) 
Em 1971 acontece a remoção da invasão do IAPI para a Ceilândia ${ }^{5}$. Nancy Araújo em depoimento no filme A Cidade é uma Só, dirigido por Queirós (2012), revela que os moradores do IAPI foram obrigados a deixarem suas casas com a promessa de irem para um lugar decente, porém quando chegaram à Ceilândia encontraram apenas estacas no chão como demarcações da nova residência. Acrescenta que não havia luz, água, esgoto ou transporte. Sentiu-se expulsa do Plano Piloto e entregue novamente a sorte na nova cidade.

O Plano Urbanístico de Brasília previa as cidades-satélites organizadas em núcleos periféricos ao Plano Piloto como forma de atender o crescimento do Distrito Federal. Taguatinga, Ceilândia, Sobradinho, Gama, Planaltina, Brazlândia, Guará e Cruzeiro são algumas delas. Porém tem-se a impressão, após passados mais de 60 anos, que o plano não foi executado a tempo para proporcionar aos moradores a sensação de acolhimento por parte da nova Capital de Juscelino Kubitscheck.

Em 1998 o Decreto 19.040 do DF:

\begin{abstract}
Proíbe a utilização da expressão "satélite" para designar as cidades situadas no território do Distrito Federal, nos documentos oficiais e outros documentos públicos no âmbito do GDF.

Considerando que as aglomerações urbanas do Distrito Federal já assumem características de cidades, cada vez mais independentes social, econômica e culturalmente do Plano Piloto;

Considerando que várias delas se constituem referência e pólos econômicos e culturais de expressão distrital e regional;

[...]Art. $1^{\circ}$ - As cidades situadas no território do Distrito Federal, deverão ser designadas pelos seus respectivos nomes em documentos oficiais e outros documentos públicos no âmbito do Governo do Distrito Federal, vedada a utilização da expressão satélite. (BRASíLIA/DF, 1998)
\end{abstract}

É fácil encontrar nas ruas moradores provenientes de várias regiões do país, como nordestinos, mineiros, catarinenses e paulistas que vieram participar da construção de Brasília, ou não, e se estabeleceram na localidade. Isso faz dessa unidade federativa uma verdadeira representação da diversidade cultural brasileira.

Em 1996 14,36\% da população brasiliense era originária de Goiás, 12,60\% de Minas Gerais, 12,25\% do Piauí e 12,09\% da Bahia, conforme Tabela 4 que é o primeiro dado oficial disponibilizado pelo Instituto Brasileiro de Geografia e Estatística (1997) com esse tipo de informação encontrado pela pesquisadora.

\footnotetext{
5 "O nome Ceilândia nasceu inspirado na sigla CEI acrescida da palavra lândia, de origem norte-americana para significar cidade muito em voga, ao tempo, na formação de núcleos sociais, no Brasil” (VASCONCELOS, 1988, p. 63).
} 
Tabela 4: Pessoas que não residiam no município da Unidade da Federação em 01.09.1991, mas residiam em 01.09.1996

\begin{tabular}{|c|c|c|c|c|c|c|c|c|c|c|c|c|c|}
\hline \multirow{2}{*}{$\begin{array}{c}\text { UF de } \\
\text { Re sidencia } \\
\text { A nterior }\end{array}$} & \multicolumn{13}{|c|}{ UF de Residencia Atual } \\
\hline & Sergip $=$ & Bahia & $\begin{array}{l}\text { Minas } \\
\text { Gerais }\end{array}$ & $\begin{array}{c}\text { Espírito } \\
\text { Santo }\end{array}$ & $\begin{array}{c}\text { Rio } \\
\text { de } \\
\text { Janeiro }\end{array}$ & $\begin{array}{l}\text { Săo } \\
\text { Paulo }\end{array}$ & Paranáa & \begin{tabular}{c|} 
Santa \\
Catarina
\end{tabular} & \begin{tabular}{|c|} 
Rio \\
Grande \\
do Sul
\end{tabular} & \begin{tabular}{|c|} 
Mato \\
Grosso \\
do Sul \\
\end{tabular} & \begin{tabular}{|c|} 
Mato \\
Grosso
\end{tabular} & Goiás & $\begin{array}{l}\text { Distrito } \\
\text { Federal }\end{array}$ \\
\hline TOTAL. & 36487 & 163402 & 315485 & 116499 & 200593 & 1139663 & 234004 & 152845 & 91479 & 87374 & 150421 & 288648 & 166849 \\
\hline Rondônia .. & 142 & 990 & 3638 & 3434 & 934 & 8292 & 8913 & 1239 & 813 & 3925 & 15707 & 2680 & 897 \\
\hline Acre ............. & 40 & 141 & 397 & 150 & 323 & 916 & 444 & 118 & 155 & 325 & 730 & 482 & 259 \\
\hline Amazonas .. & 137 & 639 & 1213 & 380 & 2235 & 3118 & 893 & 338 & 870 & 398 & 692 & 843 & 1004 \\
\hline Roraima & 31 & 125 & 325 & 73 & 221 & 1844 & 1456 & 556 & 402 & 308 & 427 & 304 & 188 \\
\hline Pará & 293 & 3063 & 5789 & 2176 & 6455 & 29377 & 2743 & 1291 & 1534 & 1178 & 6585 & 14828 & 68 \\
\hline Amapá & 13 & 63 & 189 & 50 & 97 & 457 & 84 & 45 & 56 & 46 & 81 & 483 & 64 \\
\hline Tocantins ... & 23 & 682 & 1961 & 94 & 198 & 2619 & 452 & 130 & 449 & 170 & 2713 & 22646 & 3813 \\
\hline Maranhăo ....... & 190 & 1321 & 2928 & 713 & 6385 & 21289 & 884 & 375 & 569 & 444 & 4631 & 18053 & 17756 \\
\hline Piauí ................ & 182 & 2709 & 1518 & 292 & 3329 & 42993 & 419 & 171 & 279 & 282 & 884 & 12881 & 20450 \\
\hline Ceará & 452 & 6998 & 5162 & 1423 & 19488 & 69942 & 1841 & 1358 & 1508 & 1099 & 1784 & 7664 & 10683 \\
\hline Rio Grande do Norte & 354 & 1447 & 2702 & 417 & 6896 & 19183 & 887 & 457 & 579 & 603 & 549 & 3960 & 3117 \\
\hline 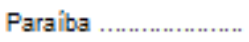 & 528 & 3522 & 1831 & 347 & 23790 & 44540 & 1595 & 350 & 508 & 497 & 952 & 3874 & 5825 \\
\hline Pernambuco ............... & 2014 & 19646 & 3849 & 910 & 12849 & 123791 & 2028 & 558 & 756 & 1684 & 1608 & 4686 & 4501 \\
\hline 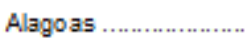 & 7070 & 6924 & 2353 & 729 & 3854 & 52085 & 1210 & 383 & 277 & 1242 & 3880 & 1280 & 945 \\
\hline Sergipe .................. & & 9315 & 1201 & 386 & 2129 & 17905 & 607 & 173 & 173 & 300 & 603 & 613 & 625 \\
\hline 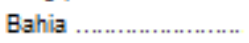 & 12426 & & 27768 & 29148 & 17005 & 284474 & 4089 & 1293 & $1 \notin 21$ & 1558 & 4781 & 29725 & 20172 \\
\hline Minas Gerais ............. & 585 & 15272 & & 38719 & 31208 & 163066 & 9068 & 2377 & 2271 & 3086 & 6481 & 27121 & 21019 \\
\hline Espirito Santo ........ & 162 & 7660 & 19403 & & 12490 & 8092 & 1187 & 525 & 430 & 244 & 794 & 875 & 1024 \\
\hline Rio de Janeiro ........... & 2421 & 11789 & 48484 & 24213 & & 48188 & 8458 & 5387 & 7369 & 3627 & 1492 & 4356 & 9936 \\
\hline Săo Paulo & 5932 & 53875 & 128743 & 8696 & 27069 & & $\$ 9 \$ 5$ & 18509 & 10878 & 30796 & 16132 & 18614 & 7711 \\
\hline Paraná .. & 205 & 2149 & 9727 & 941 & 3640 & 126837 & & 68064 & 18383 & 14724 & 28057 & 3378 & 1595 \\
\hline Santa Catarina .......... & 2348 & 1233 & 1722 & 299 & 1923 & 10819 & 42662 & & 33125 & 2053 & 5969 & 1038 & 763 \\
\hline Rio Grande do Sul .... & 164 & 2318 & 2696 & 891 & 5288 & 11689 & 19501 & 41875 & & 3843 & 6694 & 2606 & 3134 \\
\hline Mato Grosso do Sul.. & 96 & 750 & 2079 & 312 & 1733 & 22660 & 12614 & 1824 & 2099 & & 19275 & 2969 & 853 \\
\hline Mato Grosso .............. & 123 & 1313 & 6023 & 705 & 1491 & 23564 & 18081 & 3699 & 3503 & 11610 & & 15617 & 1653 \\
\hline 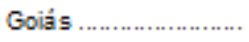 & 173 & 5169 & 25359 & 863 & 1821 & 15882 & 2233 & 815 & 1339 & 2644 & 19845 & & 24018 \\
\hline Distrito Federal ......... & 392 & 4371 & 10427 & 2148 & 5742 & 8081 & 1774 & 940 & 1563 & 723 & 1075 & 87136 & \\
\hline
\end{tabular}

Fonte: IBGE, 1997.

Segundo o Gráfico 1 os dados da Pesquisa Distrital por Amostragem de Domicílio 2004 (SEPLAN, 2004) demonstram que entre julho a outubro de 2004, período da pesquisa de campo da citada pesquisa, $48 \%$ da população brasiliense era natural do próprio Distrito Federal, $26,7 \%$ da Região Nordeste, $13,7 \%$ da Região Sudeste e 6,5\% da Região Centro-Oeste. Ficando a região sul, o entorno e o exterior, somados, com $3 \%$. 
Gráfico 1 - População imigrante do Distrito Federal por Naturalidade - 2004
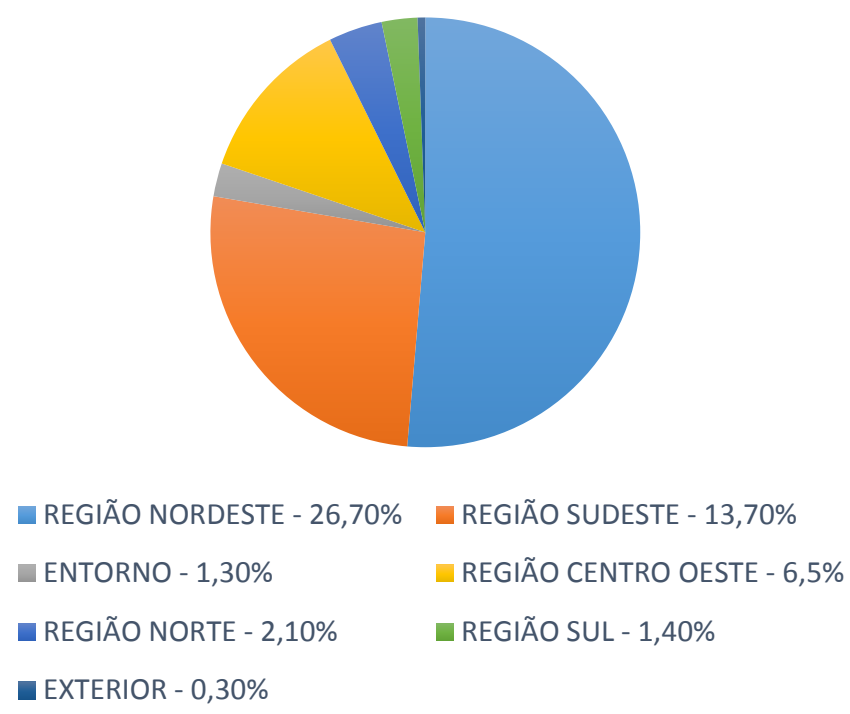

Fonte: SUBSECRETARIA DE ESTATÍSTICA E INFORMAÇÕES - SEPLAN (2004).

Conforme o levantamento da SEPLAN 2011, 48,11\% dos residentes são naturais do Distrito Federal. O gráfico 2 apresenta que do total de imigrantes a maior representação é a Região Nordeste com 51,05\%, seguido pela Região Sudeste com $27,65 \%$ da população e $13,88 \%$ do Centro-Oeste. As Regiões Norte e Sul, somadas, representam $6,84 \%$.

Gráfico 2: População Imigrante do Distrito Federal por Naturalidade - 2011

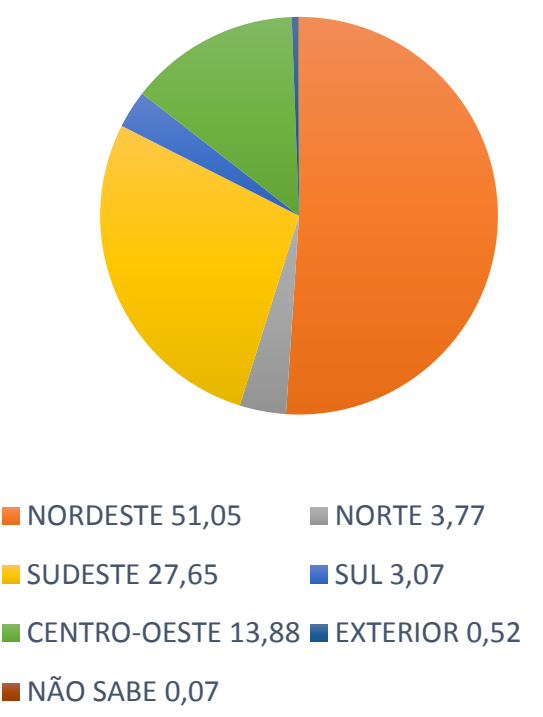

Fonte: SUBSECRETARIA DE ESTATÍSTICA E INFORMAÇÕES - SEPLAN (2011). 
Em relação aos estados a pesquisa revela que 17,56\% dos imigrantes são de Minas Gerais, 13,43\% de Goiás, Bahia e Piauí apresentam a mesma participação, $10 \%$, e $9,04 \%$ do Maranhão (SUBSECRETARIA DE ESTATÍsTICA E INFORMAÇÕES, 2011).

Quando desagregada a naturalidade por Regiões Administrativas, observase que nas regiões de maior renda, prevaleceu a população oriunda da região Sudeste, no Lago Sul com (49,6\%), Lago Norte (49,58\%) e Brasília $(44,06 \%)$, enquanto nas regiões de menor poder aquisitivo, o Nordeste foi mais representativo, no SCIA - Estrutural com 69,38\% e Itapoã 67,79\%. (SUBSECRETARIA DE ESTATÍSTICA E INFORMAÇÕES, 2011, p. 25)

Segundo o Governo do Distrito Federal (2015), o DF é dividido em trinta e uma Regiões Administrativas, (algumas são as antigas cidades-satélites) que são unidades de divisão territorial e administrativa para fins de descentralização administrativa e coordenação dos serviços públicos de natureza local.

Ao longo do tempo o Distrito Federal agregou frações, memórias, técnicas, arte, regras entre outros de muitas, se não de todas, regiões do Brasil. Arquitetada por Lucio Costa para ser a cidade de cultura lúcida, apresenta um conflito de identidade onde turistas, candangos e os próprios brasilienses se questionam a respeito da cultura alimentar típica do Distrito Federal. Sabe-se que Brasília é um interessante polo gastronômico, com restaurantes especializados em cozinhas internacionais localizados no Plano Piloto, justificados pela expressiva presença de Embaixadas na capital do país, pela residência de agentes políticos e de alguns outros habitantes com alto poder aquisitivo. Em menor número encontram-se restaurantes de cozinhas nordestinas e mineiras que atendem aos trabalhadores que formam a diversidade sócio cultural do Distrito Federal com preferências, tradições e peculiaridades que estão restritas ao entorno, no hábito do seu cotidiano, nas comidas de rua e de suas feiras.

\footnotetext{
A capital é parte hoje de uma gigantesca mancha urbana, desigual e desordenada, onde vivem, muitas vezes em condições precárias, quase três milhões de pessoas. Com mais gente, carros e edifícios do que o planejado, Brasília caminha para partilhar as mesmas aguras dos grandes centros urbanos do país. (CATALDO; RAMOS, 2010, p.31)
}

Atualmente, Brasília é uma mancha urbana em acelerada e desigual expansão. $48 \%$ da população local nasceu no próprio Distrito Federal, no Plano Piloto e nas Regiões Administrativas, espécie de bairro com identidade própria. A renda 
mensal é de mais que o dobro da renda nacional, o desequilíbrio na distribuição de renda também é mais alto que a média nacional (CATALDO; RAMOS, 2010).

Assim como em outros locais de países do terceiro mundo, o Distrito Federal apresenta grande desigualdade social e econômica entre os habitantes das Regiões Administrativas. Conforme o Censo Demográfico 2010 do Instituto Brasileiro de Geografia e Estatística (2014), a população estimada para o Distrito Federal em 2013 foi de 2.789.761 habitantes, destes 96,6\% residem em domicílios urbanos e 3,4 em domicílios rurais. A principal atividade econômica tanto do Distrito Federal quanto rn Brasília é o setor de serviços conforme Gráfico 3.

Gráfico 3: Despesas, receitas orçamentárias e PIB do DF

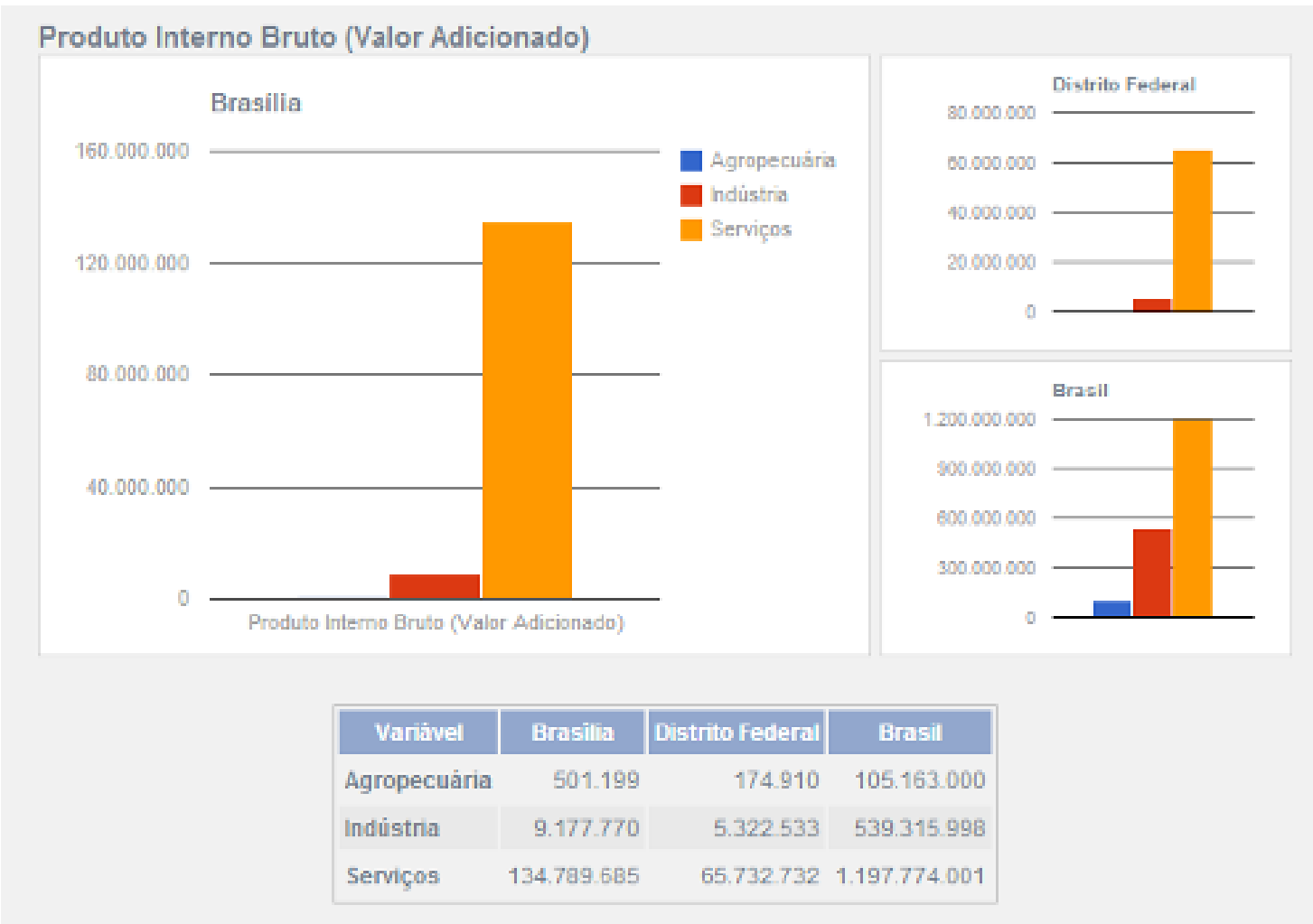

Fonte: Extraído de Instituto Brasileiro de Geografia E Estatística (2014).

Há grandes diferenças econômicas entre as Regiões Administrativas ao analisarmos a Tabela 5 - Renda Domiciliar e Per Capita. Nota-se a que Brasília, formada pelo Plano Piloto e pelo Parque Nacional, Lago Sul, Lago Norte, Sudoeste/Octogonal e Park Way possuem condições econômicas consideravelmente melhores que Planaltina, Riacho Fundo II, Santa Maria, Estrutural e Itapoã. 
Tabela 5: Renda Domiciliar e Per Capita Mensal, segundo as Regiões Administrativas do Distrito Federal (2004)

\begin{tabular}{|c|c|c|c|c|c|}
\hline $\begin{array}{l}\text { Distrito Federal e } \\
\text { Regiões } \\
\text { Administrativas }\end{array}$ & $\begin{array}{c}\text { Renda Domiciliar } \\
\text { Valores Absolutos } \\
\mathrm{R} \$ 1,00 \\
\end{array}$ & $\begin{array}{c}\text { Mensal } \\
\text { Valores em } \\
\text { Salários Mínimo } \\
\end{array}$ & $\begin{array}{c}\text { Renda Per Capita } \\
\text { Valores Absolutos } \\
\mathrm{R} \$ 1,00\end{array}$ & $\begin{array}{c}\text { Mensal } \\
\text { Valores em } \\
\text { Salários Mínimo } \\
\end{array}$ & $\begin{array}{c}\text { Coeficiente } \\
\text { de } \\
\text { Gini }\end{array}$ \\
\hline Distrito Federal & 2.332 & 9,0 & 625 & 2,4 & 0,573 \\
\hline Brasília & 5.026 & 19,3 & 1.770 & 6,8 & 0,443 \\
\hline Gama & 1.558 & 6,00 & 404 & 1,6 & 0,466 \\
\hline Taguatinga & 2.493 & 9,6 & 661 & 2,5 & 0,467 \\
\hline Brazlândia & 885 & 3,4 & 219 & 0,8 & 0,503 \\
\hline Sobradinho & 2.401 & 9,2 & 623 & 2,4 & 0,510 \\
\hline Planaltina & 825 & 3,2 & 200 & 0,8 & 0,490 \\
\hline Paranoá & 1.361 & 5,2 & 316 & 1,2 & 0,515 \\
\hline Núcleo Bandeirante & 2.157 & 8,3 & 629 & 2,4 & 0,488 \\
\hline Ceilândia & 1.211 & 4,7 & 323 & 1,2 & 0,493 \\
\hline Guará & 3.186 & 12,3 & 852 & 3,3 & 0,448 \\
\hline Cruzeiro & 3.155 & 12,1 & 807 & 3,1 & 0,452 \\
\hline Samambaia & 1.039 & 4,0 & 254 & 1,0 & 0,439 \\
\hline Santa Maria & 962 & 3,7 & 244 & 0,9 & 0,442 \\
\hline São Sebastião & 1.362 & 5,2 & 360 & 1,4 & 0,535 \\
\hline Recanto das Emas & 1.013 & 3,9 & 239 & 0,9 & 0,502 \\
\hline Lago Sul & 11.276 & 43,4 & 2.798 & 10,8 & 0,437 \\
\hline Riacho Fundo & 1.535 & 5,9 & 386 & 1,5 & 0,465 \\
\hline Lago Norte & 8.922 & 34,3 & 2.023 & 7,8 & 0,430 \\
\hline Candangolândia & 2.150 & 8,3 & 577 & 2,2 & 0,492 \\
\hline Águas Claras & 3.219 & 12,4 & 863 & 3,3 & 0,533 \\
\hline Riacho Fundo II & 845 & 3,3 & 237 & 0,9 & 0,426 \\
\hline Sudoeste/Octogonal & 6.276 & 24,1 & 2.226 & 8,6 & 0,392 \\
\hline Varjão & 728 & 2,8 & 214 & 0,8 & 0,407 \\
\hline Park Way & 5.092 & 19,6 & 1.273 & 4,9 & 0,578 \\
\hline Estrutural & 490 & 1,9 & 115 & 0,4 & 0,376 \\
\hline Sobradinho II & 1.698 & 6,5 & 438 & 1,7 & 0,523 \\
\hline Itapoã & 403 & 1,6 & 102 & 0,4 & 0,404 \\
\hline
\end{tabular}

Fonte: Companhia de Planejamento do Distrito Federal (2013).

A representação econômica de Brasília não pode ser generalizada como realidade da totalidade da população do Distrito Federal. Cada Região Administrativa que compõe o Distrito Federal possui sua singularidade seja pela formação histórica, sócio econômica ou cultural. Possuem ano de fundação/ocupação, classe social e econômica, origens e modos de vida diferentes umas das outras. Prova de que não se pode tentar identificar o Distrito Federal pelo que ocorre em Brasília é a quantidade 
de habitantes de um e de outro. Brasília possui apenas $9 \%$ da população total do DF, perdendo em número de habitantes para Ceilândia (16\%) e Taguatinga (11\%), conforme o Gráfico 4: População Residente por Região Administrativa.

\section{Gráfico 4: População Residente por Região Administrativa}

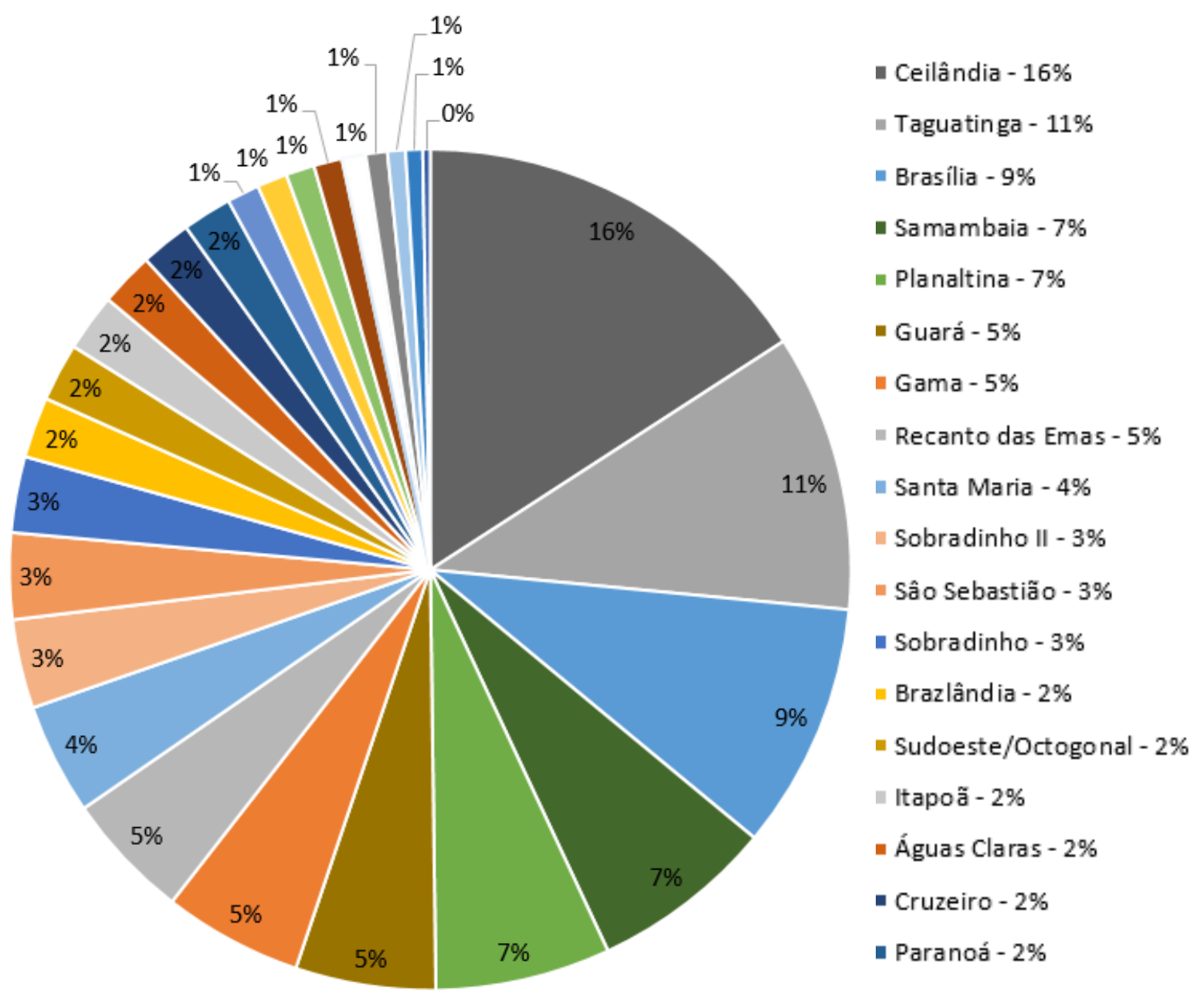

Fonte: Companhia de Planejamento do Distrito Federal (2013).

Segundo Santos (2008), essa desigualdade possibilita diferentes realidades de consumo.

A existência de uma massa de pessoas com salários muito baixos ou vivendo de atividades ocasionais, ao lado de uma minoria com rendas muito elevadas, cria uma sociedade urbana uma divisão entre aqueles que podem ter acesso de maneira permanente aos bens e serviços oferecidos e aqueles que, tendo as mesmas necessidades, não têm condição de satisfazê-las. Isso cria ao mesmo tempo diferenças quantitativas e qualitativas no consumo. Essas diferenças são a causa e o efeito da existência, ou seja, da criação ou da manutenção, nessa cidade, de dois circuitos de produção, distribuição e consumo dos bens e serviços. (SANTOS, 2008, p. 37) 
Os dois circuitos de produção a que Santos (2008) se refere são o circuito inferior e o circuito superior conforme Gráfico 5. O que difere, basicamente, um de outro é a tecnologia e a organização empregada. O primeiro emprega alta tecnologia limitando-se a copistas de soluções enquanto o segundo circuito usa a força do trabalho e atitudes criativas para se reinventar e se reestruturar uma vez que os circuitos são permeáveis e necessitam de constante reciclagem para manter-se atuantes e lucrativos em seus espaços.

Gráfico 5: Os elementos dos dois circuitos

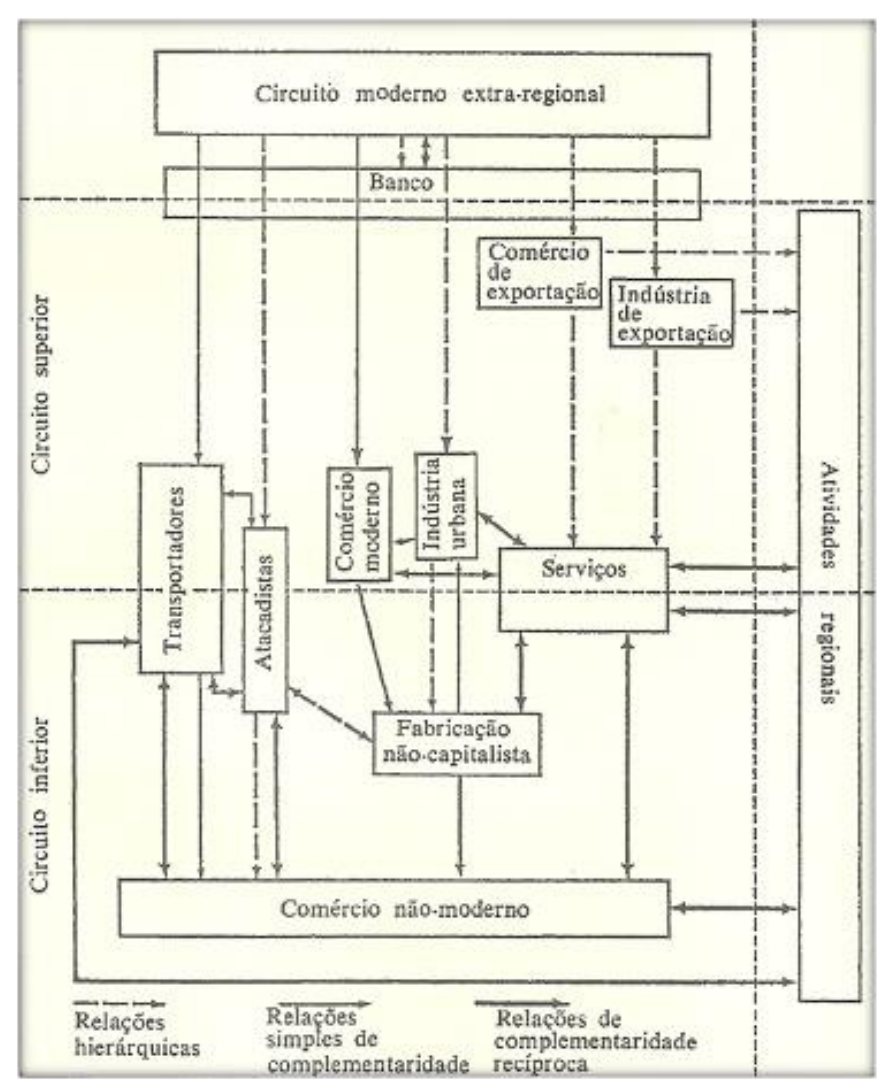

Fonte: Retirado de Santos (2008, p. 40).

O circuito superior relaciona-se fora da cidade e da região e é composto por, segundo Santos (2008, p. 40) "bancos, comércio e indústria de exportação, indústria urbana moderna, serviços modernos, atacadistas e transportadores". O circuito inferior, ao contrário, firma sua relação com o local em que está inserido. Feiras livre e mercados são atividades que compõe o circuito inferior e servem nesse contexto, segundo Sato (2012) como importantes instrumentos de análise para compreender o circuito inferior uma vez que são elementos centrais para o estudo da realidade urbana. 
A lei 235-92 publicado na DODF de 17/01/92 que regulamenta as feiras-livres e permanentes no DF considera que feira livre e permanente comercializa produtos hortifrutigranjeiros, cereais, produtos de artesanato, pescados, aves, flores, plantas, doces, laticínios, carne de sol, lanches e confecções.

Vasconcelos (1988) relata a presença das feiras nas cidades satélites desde os primórdios do nascimento como local de comercialização, principalmente, de produtos alimentares.

Segundo o Governo do Distrito Federal (2011) Brasília possui cerca de 70 feiras livres e permanente. "As livres são as que funcionam apenas nos sábados ou domingos. Já as permanentes são as que possuem estrutura fixa, como a Feira Central de Ceilândia, que tem 463 boxes" (GOVERNO DO DISTRITO FEDERAL, 2011). As principais feiras do DF estão indicadas na Imagem 9.

Para organizar e regularizar as Feiras Livres e Permanentes o Distrito Federal sancionou entre 1992 e 2014 cerca de sessenta Leis conforme tabela do Apêndice III. A lei 4748/2012 que trata da regularização, organização e funcionamento das feiras livres e permanentes no Distrito Federal especifica a organização e o tratamento de cada tipo de feira no Distrito Federal.

Art. 2o Considera-se feira livre a atividade mercantil de caráter cíclico, realizada em via, logradouro público ou pavilhão previamente autorizado para esse fim, com instalações individuais, provisórias e removíveis.

$\S 1^{\circ}$ A feira livre destina-se à venda, exclusivamente a varejo, de produtos hortifrutigranjeiros, cereais, doces, laticínios, pescados, flores, plantas ornamentais, produtos de artesanato, lanches, caldo de cana, tempe raízes, carnes e aves abatidas, resfriadas ou congeladas, confecçı tecidos, armarinhos, calçados e bolsas, bijuterias, artigos religio _.., ferramentas e utensílios domésticos, produtos da lavoura e indústria rural, e outros que possam vir a ser aprovados pelo órgão competente.

Art. 3 Considera-se feira permanente a atividade mercantil de caráter constante realizada em logradouro público destinado para esse fim, com instalações comerciais fixas e edificadas para comercialização dos produtos referidos no art. $2^{\circ}$, $\S 1^{\circ}$, e de produtos de bazar e agropecuários, refeições típicas regionais, jornais, revistas, além de prestação de pequenos serviços, na forma do regulamento.

[...]Art. 6\% Para os efeitos desta Lei, considera-se feira de abastecimento e de produtores rurais o local destinado à atividade mercantil de caráter constante, exercida em área previamente designada pelo órgão competente do Poder Executivo para a comercialização de produtos hortifrutigranjeiros.

$\S$ 10 Nas feiras de abastecimento e de produtores rurais, devem ser destinados espaços para implantação de balanças para pesagem de veículo com carga.

$\S 2^{\circ}$ Para efeitos desta Lei, o shopping popular e a feira de abastecimento e de produtores rurais equiparam-se a feira permanente. (DISTRITO FEDERAL, 2012) 
A Superintendência do Instituto do Patrimônio Histórico e Artístico Nacional do Distrito Federal iniciou ações na área do patrimônio imaterial com a execução do Inventário Nacional de Referências Culturais ${ }^{6}$ das Feiras Permanentes do Distrito Federal em 2005 por considera-las espaços capazes de reunir significados e serem espaços de grande sociabilidade (INSTITUTO DO PATRIMONIO HISTÓRICO E ARTÍSTICO NACIONAL, 2014). Vale ressaltar que o projeto foi iniciado, porém não concluído.

No total, foram identificadas 10 Feiras Permanentes, em sua grande maioria nas cidades-satélites do Distrito Federal (com suas respectivas principais referências culturais). São elas: a) Feira da Ceilândia; b) Feira do Guará; c) Feira do Núcleo Bandeirante; d) Feira de Taguatinga; e) Feira de Artesanato da Torre de TV; f) Feira dos Importados de Brasília; g) Feira de Planaltina; h) Feira do Cruzeiro; i) Feira do Gama; j) Feira de Sobradinho. (RAMASSOTE; BESSONI, 2010)

\footnotetext{
6 "O desenvolvimento do Inventário Nacional de Referências Culturais - INRC significa a disponibilização de um instrumento essencial para a identificação e documentação de bens culturais e, consequentemente, para as possibilidades de preservação desses bens. Vale enfatizar que o INCR é um instrumento de identificação de bens culturais tanto imateriais quanto materiais. A indicação de bens para Registro e/ou Tombamento pode resultar de sua aplicação, mas não obrigatoriamente. O INCR é, antes, um instrumento de conhecimento e aproximação do objeto de trabalho do IPHAN configurado nos dois objetivos principais que determinam sua concepção: 1identificar e documentar bens culturais, de qualquer natureza, para atender à demanda pelo reconhecimento de bens representativos da diversidade e pluralidade culturais dos grupos formadores da sociedade; e 2- apreender os sentidos e significados atribuídos ao patrimônio cultural pelos moradores de sítios tombados, tratando-os como intérpretes legítimos da cultura local e como parceiros preferenciais de sua preservação. (INVENTÁRIO NACIONAL DE REFERÊNCIAS CULTURAIS, 2000, p. 8)
} 


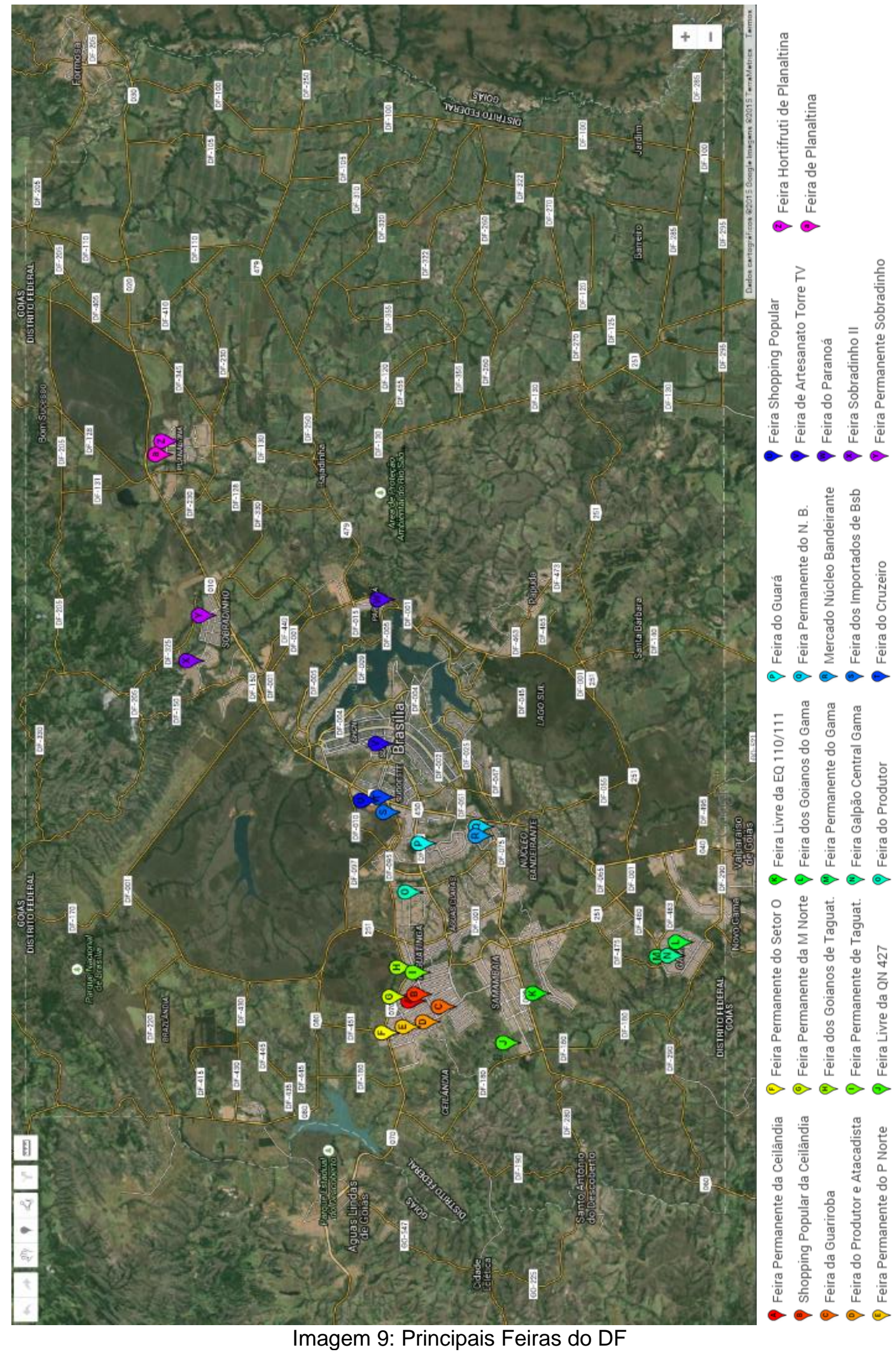

Fonte: Imagem adaptado pela pesquisadora em junho de 2015. 
A Feira do Produtor e Atacadista, em Ceilândia, tem 338 boxes com aproximadamente 10 mil metros quadrados de área, com funcionamento diário recebe cerca de três mil pessoas diariamente, com maior movimento às terças, quartas, sextas-feiras e finais de semana. $O$ comércio maior se refere a frutas, verduras e legumes no atacado e varejo (EMPRESA DE ASSISTÊNCIA TÉCNICA E EXTENSÃO RURAL DO DISTRITO FEDERAL, 2014).

Criada em 1998, a Feira dos Goianos, localizada na QI 13, 15, 17 e 18 na Avenida Hélio Prates, em Taguatinga Norte Brasília - DF, funciona de terça-feira a domingo. Apresenta reduzida quantidade de comércio alimentício, uma vez que seu foco é o comercio de vestuário e calçado de confecções localizadas em Goiânia-GO. Contudo, há a presença do comércio ambulante de caldo de cana e pastel e alguns poucos espaços destinados a restaurantes e lanchonetes que servem comida a quilo, salgados em geral, tapioca, cuscuz, açaí, churros.

Desde 1969 a Feira do Guará, é uma tradicional feira de moda, alimentos e produtos em geral. Com funcionamento atual de quinta-feira a domingo, possui restaurantes que servem de feijoada a peixada. Barracas com tapioca, queijos, grãos, peixaria e pastelaria são atrativos da feira. Assim como na feira dos goianos, a maioria de seus seiscentos boxes são destinados às confecções.

Comerciantes foram instalados na Cidade Livre (atual Núcleo Bandeirante) com isenção de impostos e de pagamento de uso de terreno durante a construção de Brasília com a ideia de serem removidos ao inaugurar a cidade, porém não foi o que aconteceu. Os moradores organizaram-se e reivindicaram sua fixação naquele local. Atualmente a Região Administrativa do Núcleo Bandeirante possui cerca de trinta e seis mil habitantes onde o comércio atacadista recebe destaque entre as atividades. O tradicional Mercado do Núcleo Bandeirante, com três décadas de funcionamento, possui cerca de duzentos boxes que trabalham com grandes redes de varejo. São comercializados principalmente roupas, comidas e bebidas, serviços de cabeleireiros e conserto de aparelhos eletrônicos. A Feira Permanente do Núcleo Bandeirante funciona diariamente e é uma das mais tradicionais feiras do Distrito Federal. Em seus cento e oito boxes é possível encontrar um pouco de tudo, especialmente comidas típicas mineiras e nordestinas como rabada, carne de cabrito, sarapatel, buchada de bode, mocotó e churrasco misto, além de hortifrúti e ervas frescas, fumo de rolo, queijos tipo minas, doces caseiros, pamonhas, farinhas e grãos. Os frequentadores 
também podem escolher aves de algumas espécies, como galinhas, patos e perus, para que sejam abatidas na hora.

Os primeiros moradores da atual Região Administrativa XI Cruzeiro foram os que vieram trabalhar na época da construção de Brasília, funcionários públicos e militares vindos do Rio de Janeiro em 1955. Atualmente a comunidade se reúne tradicionalmente na Feira Permanente do Cruzeiro, criada em 1970 para atender as necessidades dos moradores. Durante muito tempo as bancas eram de madeira e o chão batido, hoje a estrutura é metálica e possui oitenta boxes com frutas, verduras, queijos, peixes, carnes, embutidos, farináceos, roupas, descartáveis, calçados, restaurantes e lanchonetes (SILVA, 2011).

Fundada em 1971 para resolver problemas de moradia a RA IX Ceilândia atualmente é a região de maior densidade urbana, segundo Anuário do Distrito Federal (2012). Ainda, possui o maior número de comerciários e verifica-se grande quantidade de feiras na região das quais se destaca a Feira Permanente da Ceilândia, também conhecida como Feira Central, inaugurada em 1984. A Feira Central possui quatrocentos e sessenta boxes dos mais diversos segmentos, como vestuário, calçados, utilidades para o lar, doces, queijos, ervas, temperos, tabaco, peixes, carnes, frutas, verduras e restaurantes com: baião de dois, mocotó, buchada, galinha cozida, dobradinha, carne de sol, rabada, sarapatel, feijão tropeiro e galinha caipira. Recebe cerca de dez mil visitantes por semana com funcionamento de quarta-feira ao domingo.

Além das tradicionais feiras o Distrito Federal inaugura em 1986 a primeira feira de alimentos sem agrotóxicos do DF. Chegou timidamente com a reunião de cerca de dez produtores, porém hoje existem dezenove feiras dedicadas ao comércio de produtos sem defensivos químicos espalhadas pelo Plano Piloto. "O DF também se tornou a unidade da federação com maior número de feiras por habitante. Espalhadas por toda a cidade, garante uma oferta de itens quase diário" (BECKER; LOBÃO, 2014, p. 25). O que motiva os brasilienses a buscarem cada vez mais produtos sem defensivos químicos são o perceptível sabor diferenciado dos insumos, o teor mais elevado de vitaminas e minerais, a diminuição dos impactos ambientais e, a exemplo do acontece nos Estados Unidos e Europa desde a crise de 2008, o fomento de emprego e renda das áreas mais próximas. 
Brasília é plural, complexa, contraditória, símbolo e exceção. Crescer e ser criado em uma cidade em construção, não apenas estrutural como identitária e culturalmente não é tarefa fácil.

Os brasileiros não conhecem sua capital.

\begin{abstract}
Há muito - ou talvez desde o começo - a parte substituiu o todo: Brasília reduziu-se a Esplanada dos Ministérios e à Praça dos Três Poderes. E esse território simbólico da política nacional, pantanosos e fético, é alvo de desprezo e ódio. Os brasileiros, meu amigo, não amam sua capital. Alguns dizem que o objetivo era esse mesmo: a construção do novo Distrito Federal no Centro-Oeste, com seu traçado antimultidão, serviu justamente para isolar e blindar o poder. (CATALDO; RAMOS, 2010, p. 29)
\end{abstract}

O DF possui quase 4 milhões de habitantes, mas o núcleo do poder não se mistura às Regiões Administrativas. É uma cidade dentro da cidade, que permite contemplar a distância a cidade e o país. Uma verdadeira "ilha da fantasia". Os habitantes da cidade sofrem com a distância imposta, os conceitos e pré-conceitos do restante do país.

\begin{abstract}
Mas há uma cidade como outra qualquer pulsando em Brasília; cidade que ganha o pão com o suor do rosto, se endivida e se indigna com os desmandos da governança, compartilhando as aflições dos demais brasileiros, cidade que em poucas décadas, reproduz o cinturão de carência de uma periferia violenta, como nas demais capitais. Assim como há a Baixada Fluminense, formada em três séculos ao redor da antiga capital federal, há a "Baixada Brasiliense", formada em poucas décadas na periferia do poder no Planalto. (CATALDO; RAMOS, 2010, p. 39)
\end{abstract}

O que torna Brasília diferente das outras capitais é o fato do Estado ter precedido a sociedade. "Por isso, fala-se habitualmente de duas Brasílias: a institucional e a real. A institucional surgiu de um decreto, projetou-se numa maquete de arquiteto, povoou-se por meio de transferências compulsórias. Uma sociedade fabricada pelo Diário Oficial" (CATALDO; RAMOS, 2010, p. 39). A real se instalou em busca de prosperidade, oportunidades profissionais e melhor qualidade de vida, o que muitas vezes, não ocorreu.

Com seu formato, Brasília induz a segregação social, é seccionada em setores e rodeada por Regiões Administrativas que propicia o isolamento e o convívio apenas com iguais, a vizinhança. 
Nesse caminho, os olhos dos administradores locais terão que estar voltados muito menos para a Esplanada dos Ministérios e mais para as áreas distantes do Plano Piloto. São os locais que abrigam grandes contingentes de mão de obra excedente, ansiosa por oportunidades que o antigo Eldorado costumava oferecer em profusão. (CATALDO; RAMOS, 2010, p. 85)

As práticas de convivência social nas feiras do Distrito Federal recuperam a horizontalidade do tecido social rompido pela lógica de segregação urbana construída ao longo da história da capital. $\mathrm{Na}$ busca da resposta ao problema de pesquisa de como as feiras desempenham o papel de ressignificação da identidade coletiva a partir da hospitalidade, comensalidade e convivência, trilharemos no segundo capítulo dessa dissertação um estudo etnográfico sobre a feira Permanente da Ceilândia/DF. 


\section{DO OBJETO VISÍVEL A SUA ESSÊNCIA: o valor simbólico do encontro na Feira da Ceilândia}

Com o objetivo de analisar os processos de hospitalidade, comensalidade e convivência da feira Permanente da Ceilândia/DF como espaço de experiência turística no DF e responder ao problema de pesquisa de como as feiras desempenham o papel de ressignificação da identidade coletiva a partir da hospitalidade, comensalidade e convivência, foram indicadas as seguintes questões de pesquisa:

- Como se expressa a hospitalidade no encontro possibilitado pela feira de Ceilândia?

- Como se expressa a comensalidade no encontro possibilitado pela feira de Ceilândia?

- Como se expressa a convivência no encontro possibilitado pela feira de Ceilândia?

- A feira da Ceilândia pode ser considerada um espaço de experiência turística?

- O que leva o feirante da feira de Ceilândia a incluir um prato de origem regional no cardápio de sua banca sendo uma feira no DF?

- Existe algum processo diferenciado de atendimento ao cliente na feira de Ceilândia que identifique as características de origem regional?

- Em que aspectos da cultura regional os frequentadores da feira de Ceilândia se reconhecem?

- Qual a relação de pertencimento/identificação que os feirantes têm com a feira?

- Qual a relação de pertencimento/identificação que os visitantes têm com a feira?

- A feira da Ceilândia é um espaço de representação das diferentes culturas regionais do Brasil no DF?

As questões de pesquisa propostas foram evidenciadas a partir da trilha metodológica que teve como caminho a etnometodologia do estudo de caso feira Permanente de Ceilândia/DF. 


\subsection{Traçando a Trilha Metodológica}

Para fazer jus à complexidade do tema foi utilizada a pesquisa qualitativa, cujo entendimento exige mais que a mensuração de dados e onde o interesse é pautado também no lado subjetivo dos fenômenos, preservando a dinâmica enquanto é analisada (DEMO, 2000). O nível de profundidade foi de caráter exploratório/explicativo. Explicativo para cercar o tema de todos os lados possíveis resultando em uma abordagem adequada e exploratório para obter conhecimento mais profundo sobre o tema.

O Estudo de Caso foi utilizado como método de investigação da pesquisa cujo objetivo foi analisar exaustivamente uma unidade social em seu contexto real, sem controle de variáveis a fim de construir uma teoria que possa explicar ou prever um caso concreto da realidade social (MARTINS, 2007). Não se pretendeu com o Estudo de Caso comprovar pressuposições iniciais da pesquisadora, tão pouco realizar um relato histórico. Desejou-se descrever, interpretar e explicar as relações e fenômenos que ocorrem a fim de ter-se evidencias válidas ao estudo do tema. Um protocolo de aproximação detalhada pelas questões de pesquisa possibilitou o estudo construído. Foi utilizado um diário de pesquisa para registro das evidencias.

A etnografia foi o caminho escolhido por ser uma prática que, segundo Geertz (1978), estabelece relações, selecionam informantes, transcreve textos, levanta genealogias, mapeia campos, entre outros.

O fazer etnográfico para Geertz (1978) é uma construção do autor, ou seja, reconstrução das construções de outras pessoas sendo apenas a ponta do iceberg do fenômeno social.

[...] pois a maior parte do que precisamos para compreender um acontecimento particular, um ritual, um costume, uma ideia, ou o que quer que seja está insinuado como informação de fundo antes da coisa em si mesma ser examinada diretamente. (GEERTZ, 1978, p. 19)

Assim, a pesquisa antropológica leva a escolha de um caminho de significados que indique sua importância e sua base social. 
A análise é portanto, escolher entre as estruturas de significação - o que Ryle chamou de códigos estabelecidos, uma expressão um tanto mistificadora, pois ela faz com que o empreendimento soe muito parecido com a tarefa de um decifrador de códigos, quando na verdade ele é muito mais parecido com a do crítico literário - e determinar sua base social e sua importância. (GEERTZ, 1978, p.19)

A etnografia é uma descrição densa. A proposta do relato etnográfico não foi a de interpretar dados coletados, uma vez que apenas os nativos à fariam de maneira pertinente, mas sim de esclarecer o que ali ocorre, de conservar para estudo, de registrar o significado do acontecimento comunicado, mesmo que não seja o escrito $o$ ato puro.

Fazer a etnografia é como tentar ler (no sentido de "construir uma leitura de") um manuscrito estranho, desbotado, cheio de elipses, incoerências, emendas suspeitas e comentários tendenciosos, escritos não com os sinais convencionais do som, mas com exemplos transitórios de comportamentos modelados. (GEERTZ, 1978, p. 20)

Comportamento humano é uma ação simbólica. Questionar se a cultura é uma conduta padronizada ou um estado da mente ou as duas coisas não faz sentido. "O que devemos indagar é qual é a sua importância: o que está sendo transmitido com a sua ocorrência e através da sua agencia, seja ela um ridículo ou um desafio, uma ironia ou uma zanga, um deboche ou um orgulho" (GEERTZ, 1978, p. 21).

Nesse contexto buscou-se a inserção da pesquisadora no dia-a-dia do objeto - Feira Permanente da Ceilândia/DF, aonde a etnografia conduziu a procura de fontes múltiplas de dados e evidencias para obter diferentes pontos de vista sobre o objeto pesquisado possibilitando compreender de forma ampla as relações que se dão naquele espaço.

Etnografia significa literalmente a descrição de um povo. É importante entender que a etnografia lida com gente no sentido coletivo da palavra e não com indivíduos. Assim sendo, é uma maneira de estudar pessoas em grupos organizados, duradouros, que podem ser chamados de comunidade ou sociedade. (ANGROSINO, 2009, p. 16)

Para dar conta da complexidade e melhorar a qualidade da pesquisa foram utilizadas as seguintes técnicas de coleta de dados:

a) Pesquisa Bibliográfica que buscou construir a base teórica de caráter explicativo apoiada na literatura disponível; 
b) Observação Participante com inserção da pesquisadora no universo físico estudado a fim de criar condições para que a coleta das informações fosse realizada pelos olhos da própria pesquisadora, que certamente modificará e será modificado pelo meio, com descrição dos eventos ocorridos;

c) Entrevista com pessoas fontes (feirantes, transeuntes e frequentadores), para compreender o sentido e significado que os atores sociais, pelas suas variadas vozes, imprimem e atribuem em suas ações e situações que foram confrontadas com as observações de campo e outras evidencias;

d) Registro etnográfico visual para facilitar a reconstituição de aspectos materiais.

A primeira fase de investigação se deu com a realização de teorização sobre o tema. De leituras e fichamentos sobre o que foi encontrado sobre feiras e mercados no mundo e no Brasil o primeiro capítulo dessa pesquisa se estruturou de modo a abordar o objeto sob as perspectivas que nortearam as demais fases de investigação.

A segunda fase do estudo iniciou-se pelo mapeamento das barracas, do produto que comercializam e dos diferentes espaços da feira Central da Ceilândia e sua valorização pela administração, feirante e frequentadores.

Em seguida investigou-se a função da feira para os atores se espaço prioritário de comércio, ou, de lazer e interação social.

Numa pesquisa sobre feira, o investigador deve levar em conta uma das primeiras regras da Etnografia: deve começar o registro pelo que é mais visível, contando o total de barracas, descrevendo seu conteúdo, avaliando a população de vendedores e compradores. (MOTT, 2000, p. 27)

Após a identificação das bancas da feria que preparam e comercializam alimentos e bebidas (estima-se 30 bancas), seguindo Mott (2000), a terceira fase de investigação foi da composição demográfica dos vendedores, origens dos feirantes, relação do feirante e visitante com a feira, entre outros, com entrevistas a feirantes das bancas que preparam e comercializam alimentos e bebidas autodenominadas nordestinas.

Desse modo, uma trilha metodológica exaustiva e detalhada foi realizada com foco nas bancas de culinária, autodenominadas como nordestinas com o objetivo de obter conhecimento mais profundo do grupo (frequentadores e feirantes). Assim, gerando evidencias sobre a cultura brasiliense pela gastronomia e demais práticas, 
exercidas no espaço do encontro da feira Permanente de Ceilândia, como seus signos e significados associadas a ela. Inclui-se nessa etapa entrevista com os frequentadores, comensais dessas bancas, a fim de identificar o que buscam e/ou esperam desse espaço de encontro.

O resultado da inserção da pesquisadora na reconstrução do objeto é um relato etnográfico, escrito na primeira pessoa, sobre a feira Permanente da Ceilândia com foco na comensalidade.

A análise das evidencias é apresentada em seguida na forma impessoal com o intuito de preservar a qualidade subjetiva da investigação.

Assim, a pesquisa cumpriu seu objetivo ao analisar o espaço da feira, pela gastronomia produzida para a comunidade local da Região Administrativa de Ceilândia, que possui "múltiplas possibilidades de abordagem e interpretações, além de representar rica experiência humana e antropológica” (MOTT, 2000, p. 34).

\subsection{Descrevendo o Objeto de Estudo - A Feira da Ceilândia}

A Ceilândia é o local escolhido para a investigação por ser a Região Administrativa com a maior densidade urbana e população do Distrito Federal, conforme Tabela 6, e um histórico de exclusão/tentativa de isolamento desde sua fundação no ano de 1971.

A Feira Permanente da Ceilândia foi a escolhida entre as feiras da RA Ceilândia por estar entre as dez feiras (Feira da Ceilândia, Feira do Guará, Feira do Núcleo Bandeirante, Feira de Taguatinga, Feira de Artesanato da Torre de TV, Feira dos Importados de Brasília, Feira de Planaltina, Feira do Cruzeiro, Feira do Gama e Feira de Sobradinho) do Distrito Federal pesquisadas pela Superintendência do IPHAN-DF consideradas espaços capazes de reunir significados e serem espaços de grande sociabilidade. 
Tabela 6: População por Regiões Administrativas do DF (2013)

\begin{tabular}{|c|c|c|}
\hline $\begin{array}{c}\text { Distrito Federal e } \\
\text { Regiões Administrativas }\end{array}$ & $\begin{array}{l}\text { População Total } \\
2011 \\
\end{array}$ & $\begin{array}{l}\text { População Total } \\
2013\end{array}$ \\
\hline \multicolumn{3}{|c|}{ Valores Absolutos } \\
\hline Plano Piloto & 209.926 & 216.489 \\
\hline Gama & 127.475 & 134.958 \\
\hline Taguatinga & 197.789 & 212.863 \\
\hline Brazlândia & 49.418 & 51.121 \\
\hline Sobradinho & 59.024 & 63.715 \\
\hline Planaltina & 161.812 & 185.692 \\
\hline Paranoá & 42.427 & 46.233 \\
\hline Núcleo Bandeirante & 22.569 & 23.714 \\
\hline Ceilândia & 404.287 & 451.872 \\
\hline Guará & 107.817 & 119.923 \\
\hline Cruzeiro & 31.230 & 32.182 \\
\hline Samambaia & 201.871 & 228.356 \\
\hline Santa Maria & 119.444 & 122.721 \\
\hline São Sebastião & 77.793 & 98.908 \\
\hline Recanto das Emas & 124.755 & 138.480 \\
\hline Lago Sul & 29.677 & 30.629 \\
\hline Riacho Fundo & 35.268 & 37.606 \\
\hline Lago Norte & 33.526 & 34.182 \\
\hline Candangolândia & 15.953 & 16.886 \\
\hline Águas Claras & 109.935 & 118.864 \\
\hline Riacho Fundo II & 37.051 & 39.424 \\
\hline Sudoeste/Octogonal & 51.565 & 52.273 \\
\hline Varjão & 9.021 & 9.292 \\
\hline Park Way & 19.648 & 19.727 \\
\hline Estrutural & 32.148 & 35.094 \\
\hline Sobradinho II & 94.279 & 97.466 \\
\hline Jardim Botânico & 23.856 & 25.302 \\
\hline Itapoã & 56.360 & 59.694 \\
\hline SIA & 2.448 & 1.997 \\
\hline Vicente Pires & 67.783 & 72.415 \\
\hline Fercal & $\ldots$ & 8.408 \\
\hline Distrito Federal & 2.556 .149 & 2.786 .255 \\
\hline
\end{tabular}

Fonte: Companhia de Planejamento do Distrito Federal, 2013.

Ceilândia nasceu como solução para resolver o problema de invasões que se instalavam nas redondezas do Plano Piloto durante a década de 1960. Segundo Vasconcelos (1988) em 1970 existiam cerca de cem mil pessoas (15\% da população na época) vivendo em condições de favelados em Brasília nas áreas próximas ao 
Núcleo Bandeirante, com destaque para a Invasão do API, Vila Tenório, Esperança, Bernardo Sayão e Colombo e os morros do Urubu e Querosene. A proposta erradicação de favelas era inovadora à época uma vez que:

[...] convenceu-se de que não era somente construir a casa ou o apartamento para o favelado. Mas, promover um processo onde houvesse uma adesão de ideias de remoção, uma participação de todo o núcleo de família, e oferecidas as condições de construção da casa própria pelos favelados, num ambiente dotado de equipamentos comunitários básicos - água, luz, escola, hospitais etc - que posteriormente seriam ampliados. Portanto, algo novo do que se fizera, anteriormente. $O$ proposito maior era o de integrar uma população marginalizada dentro de um novo tipo de comunidade organizada, assegurando-se a ela melhores condições de vida e de bem estar social, e criando-se, nela, se possível, com o tempo, uma elevação do nível de aspiração social e intelectual. (VASCONCELOS, 1988, p. 60)

O projeto da comissão de Erradicação de Invasões previa a remoção, a implantação de dezessete mil lotes e equipamentos comunitários essenciais. O projeto urbanístico era de autoria do arquiteto Ney Gabriel de Souza e constituía-se de dois eixos cruzados em ângulo de 90 graus, formando a figura de um barril. Em 27 de março de 1971 a remoção foi iniciada sendo concluída um ano depois. Os que chegaram primeiro encontraram apenas a demarcação dos lotes por estacas e nada mais. A recém comunidade reivindicou água e iluminação pública, sendo atendida meses depois. Somente em 1982 os demais serviços comunitários, como saneamento básico, serviço de saúde, educação, transporte e asfaltamento, foram consolidados, possibilitando assim ao morador melhores condições de vida. Atualmente o número de domicílios, estimado pela Companhia de Planejamento do Distrito Federal (2013), é de 126.765. A maneira como foi realizada a remoção provocou múltiplas rupturas, inclusive de natureza cultural, que estão marcadas na memória dos "invasores".

No início não havia comércio em Ceilândia, os produtos eram comprados no caminhão da Companhia Brasileira de Alimentos - COBAL e frutas e verduras eram buscados na xepa da CEASA. Produto de uma política discriminatória de gerenciamento urbano Ceilândia nascia, na prática, como depositária de uma parcela da população que não era bem vinda no Plano Piloto. Segundo depoimento dos removidos Avani e Cosme, fornecido a Luiz (2007, p. 71), eles não tiveram escolha, nem podiam achar bom ou ruim, as pessoas não se conheciam, havia lama ou poeira, bichos, mortes e sofrimento. "Aquele não era nosso mundo", completa Cosme.

A erradicação das invasões, decisão administrativa, partiu as teias da trama cotidiana dos acampamentos de operários transferindo-os não apenas para uma nova 
"cidade" mas para um não-lugar. Laços de identificação foram rompidos pela segunda vez - a primeira quando trocaram suas terras natais por melhores oportunidades na capital da nação.

Ceilândia hoje possui uma área urbana de 29,10 quilômetros quadrados situada a oeste de Brasília, distante trinta e oito quilômetros da rodoviária do Plano Piloto. A região Administrativa IX Ceilândia foi criada pela lei N $49 / 89$ e pelo Decreto 11.921/89. A população urbana foi estimada, em 2013, em 449.592 habitantes (COMPANHIA DE PLANEJAMENTO DO DISTRITO FEDERAL, 2013).

Inicialmente Ceilândia era composta pelos setores Ceilândia Centro, Ceilândia Norte, Ceilândia Sul e parte da Guariroba, integrantes do "barril" projetado pelo arquiteto Ney Gabriel de Souza, conforme Imagem 10. Posteriormente foram constituídos os setores Expansão, Setor O, P Norte, P Sul, QNR, QNQ, Setor Privê, Setor de Indústrias e Materiais de Construção, Pôr do Sol e Sol Nascente e parte das áreas do INCRA.

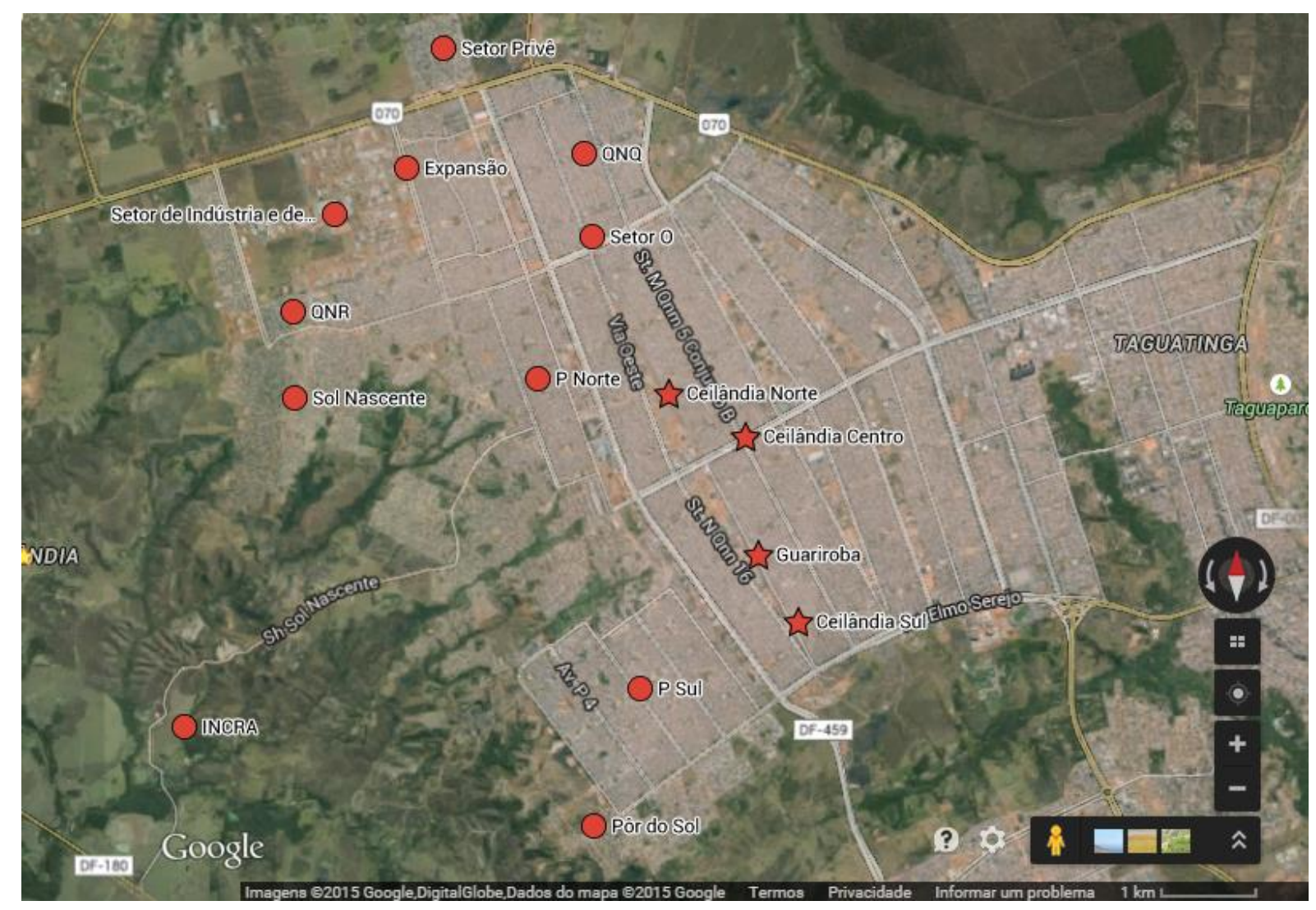

Imagem 10: Ceilândia

Fonte: Imagem adaptada pela pesquisadora em junho de 2015. 
A renda per capita mensal em Ceilândia, segundo pesquisa da CODEPLAN realizada em 2004 é de 1,2 salários mínimos enquanto a média no Distrito Federal é o dobro, 2,4 salários mínimos (Companhia de Planejamento do Distrito Federal, 2013).

A naturalidade dos habitantes de Ceilândia segundo Tabela 7 é formada por $51,73 \%$ do próprio Distrito Federal e $48,27 \%$ de nascimentos constituídos por imigrantes.

Tabela 7: População imigrante segundo a naturalidade - Ceilândia (2013)

\begin{tabular}{|c|c|c|c|}
\hline Unidade de Federação & Número & $\%$ & $\%$ de Imigrantes \\
\hline Total & 449.592 & 100,00 & \\
\hline Distrito Federal & 232.594 & 51,73 & \\
\hline Outras UF & 216.998 & 48,27 & 100,00 \\
\hline Acre & 75 & 0,02 & 0,03 \\
\hline Alagoas & 632 & 0,14 & 0,29 \\
\hline Amapá & - & - & . \\
\hline Amazonas & 70 & 0,02 & 0,03 \\
\hline Bahia & 28.311 & 6,30 & 13,05 \\
\hline Ceará & 21.449 & 4,77 & 9,88 \\
\hline Espírito Santo & 1.012 & 0,23 & 0,47 \\
\hline Goiás & 28.229 & 6,28 & 13,01 \\
\hline Maranhão & 25.405 & 5,65 & 11,71 \\
\hline Mato Grosso & 393 & 0,09 & 0,18 \\
\hline Mato Grosso do Sul & 398 & 0,09 & 0,18 \\
\hline Minas Gerais & 30.697 & 6,83 & 14,15 \\
\hline Pará & 1.925 & 0,43 & 0,89 \\
\hline Paraíba & 22.452 & 4,99 & 10,35 \\
\hline Paraná & 734 & 0,16 & 0,34 \\
\hline Pernambuco & 7.976 & 1,77 & 3,68 \\
\hline Piauí & 30.482 & 6,76 & 14,05 \\
\hline Rio de Janeiro & 2.096 & 0,47 & 0,97 \\
\hline Rio Grande do Norte & 7.363 & 1,64 & 3,39 \\
\hline Rio Grande do Sul & 570 & 0,13 & 0,26 \\
\hline Rondônia & 286 & 0,06 & 0,13 \\
\hline Roraima & 70 & 0,02 & 0,03 \\
\hline Santa Catarina & 70 & 0,02 & 0,03 \\
\hline São Paulo & 2.854 & 0,63 & 1,32 \\
\hline Sergipe & 75 & 0,02 & 0,03 \\
\hline Tocantins & 3.234 & 0,72 & 1,49 \\
\hline Exterior & 140 & 0,03 & 0,06 \\
\hline Não Sabe & - & & \\
\hline
\end{tabular}

Fonte: Companhia de Planejamento do Distrito Federal, 2013, p. 31. 
Do total de imigrantes, $66,43 \%$ são naturais do Nordeste, $16,91 \%$ do Sudeste e $13,37 \%$ do Centro-Oeste conforme gráfico 6.

Gráfico 6: População imigrante, segundo a naturalidade - Ceilândia/DF - 2013

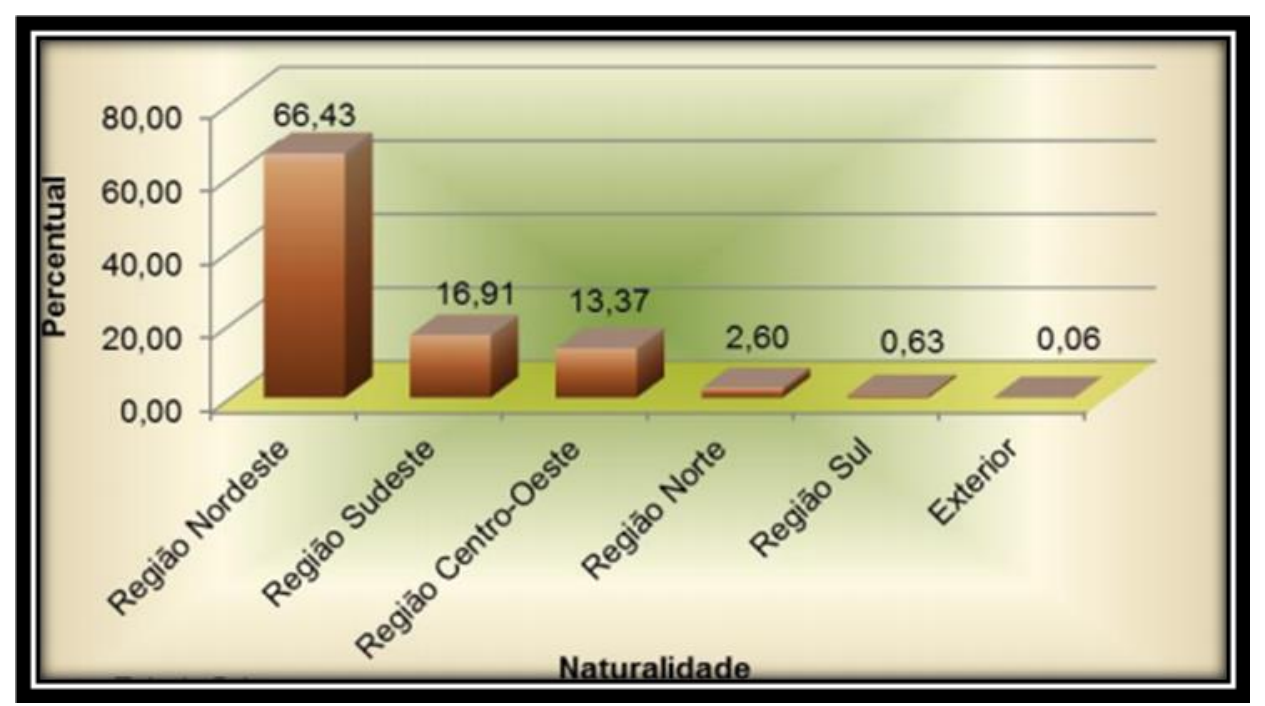

Fonte: Retirado de Companhia de Planejamento do Distrito Federal, 2013, p. 32.

Dessa forma, constata-se que a Ceilândia é composta por habitantes de variadas regiões brasileiras, o que imprime à $\mathrm{RA}$, e ao DF, a diversidade cultural característica de espaços compostos por hibridização cultural.

Os traços da cultura nordestina expressos pela comida, o cordel e a Casa do Cantador, e a quantidade majoritária de população imigrante originada da região Nordeste $(66,43 \%)$ dão indícios do perfil identitário da população da Ceilândia.

A pouco mais de uma década Ceilândia era excluída, marginalizada e violenta.

[...] a imagem de Ceilândia, tanto no Plano Piloto quanto nas outras cidadessatélites de Brasília, é a de uma cidade violenta, tomando-se por base o noticiário da imprensa e as ocorrências policiais que ali se registram. (VASCONCELOS, 1998, p. 94)

Contudo a Região Administrativa de maior densidade urbana ressignifica-se e hoje assiste à instalação do Centro Administrativo do Distrito Federal no Centro Metropolitano de Taguatinga, localizado nos limites territoriais das Regiões Administrativas Ceilândia, Taguatinga e Samambaia.

O complexo do novo Centro Administrativo terá área total de 178 mil metros quadrados e abrigará entre 12 a 15 mil servidores públicos. O projeto do complexo 
inclui, além das instalações governamentais, museus, bibliotecas públicas, parques urbanos, área residencial e um campus da Universidade de Brasília. As obras foram iniciadas em 2011 e em novembro de 2013 tinham 55\% das obras previstas no projeto concluídas (DISTRITO FEDERAL, 2013).

O Centro Metropolitano será composto, como demostra Imagem 11, por 97.891 metros quadrados destinados ao Centro Administrativo, mais de 80 mil metros quadrados de área residencial, 81 mil metros quadrados destinados ao uso institucional, 310 mil metros quadrados destinados ao uso terciário, 36. 740 metros quadrados destinados a centro comercial, mais de 140 mil metros quadrados estão destinados ao Sambódromo, 30 mil metros quadrados destinados a Terminal Rodoviário, e 76 mil metros quadrados destinados à área urbanizável do novo Campus da Universidade de Brasília. A população estimada é de 3.105 habitantes e a população flutuante estimada em 58.974 pessoas/dia (DISTRITO FEDERAL, 2015).

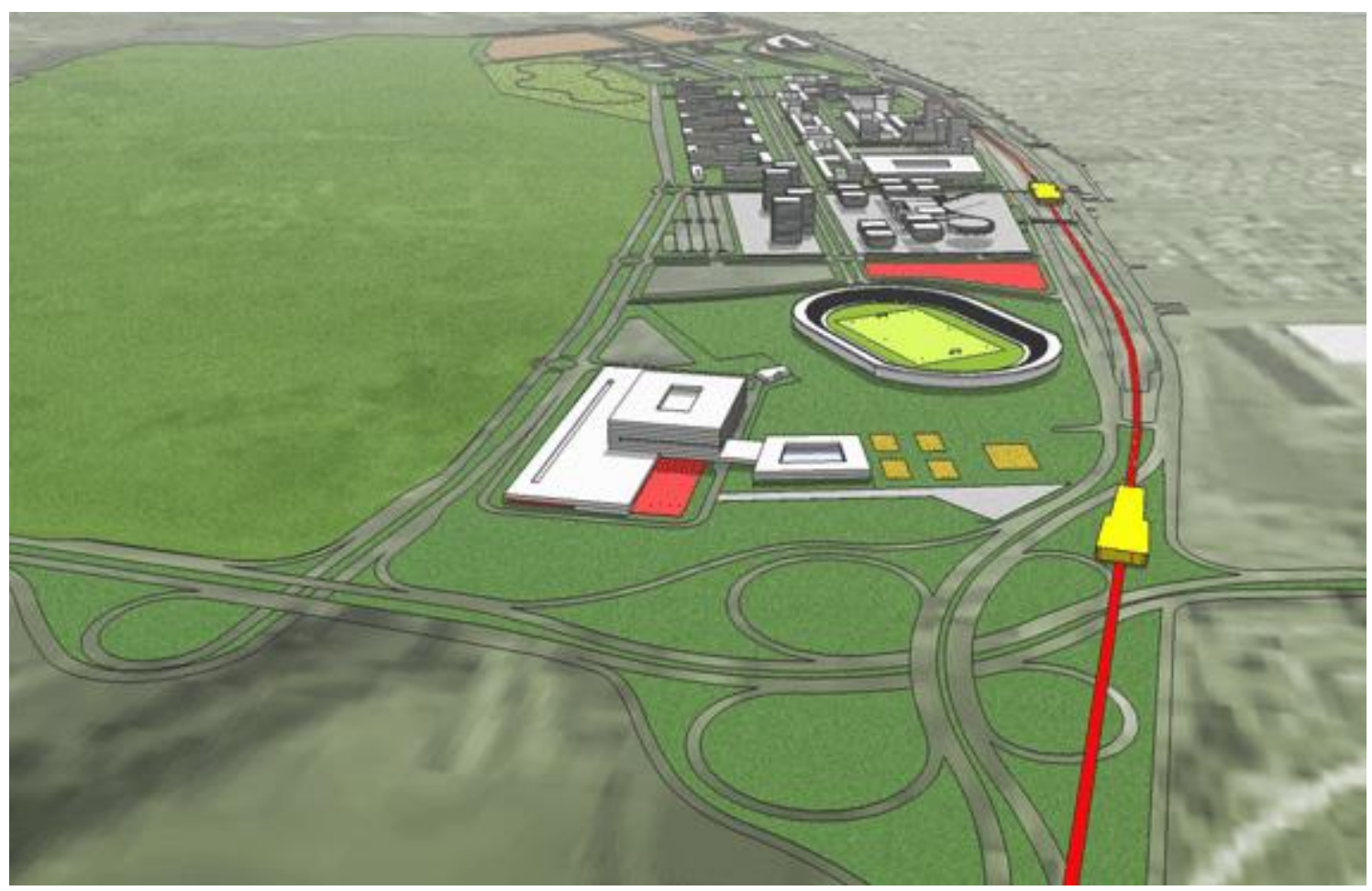

Imagem 11: Projeto Centro Metropolitano

Fonte: Retirado de Distrito Federal, 2015. 
O Centro Metropolitano se caracteriza como complexo de empreendimentos com potencial de desencadear transformações urbanas. Algumas já são notadas, como a valorização imobiliária.

\begin{abstract}
Nas imediações da área delimitada para a implantação do Centro Metropolitanos, desde o anúncio da criação deste novo complexo distrital já é possível notar alguns processos e consequências com rebatimento espacial. Dentre eles destacam-se: o aumento do preço da terra, a apropriação indevida dos investimentos públicos por parte de grandes incorporadoras em seus empreendimentos, o surgimento de diversos condomínios habitacionais, bem como o intenso processo de verticalização. Essas consequências são perceptíveis devido às modificações paisagísticas que a área em questão tem presenciado. (SERRANO, 2014, p. 122)
\end{abstract}

Cabral (2014) aponta que desde a década de 1990 os governantes do Distrito Federal trabalham com a ideia de descentralizar as atividades políticas do Plano Piloto a fim de gerar economia e melhorar a mobilidade urbana no Plano Piloto. Espera-se com a efetivação desse complexo a promoção do desenvolvimento local, a projeção da periferia distrital à subcentralidade metropolitana e, ainda, a valorização simbólica e material das áreas próximas.

A inauguração da nova sede do governo estava prevista para dezembro de 2014 segundo Correio Braziliense (2014), porém não se concretizou. Por estar em implantação os impactos, positivos e negativos, não são (re)conhecidos em sua totalidade, contudo, pela monumentalidade e montante investido, pode-se esperar alterações espaciais, modificações de fluxos, instalações de novos fixos, valorização simbólica e material e criação de oportunidades nas imediações. Os investimentos públicos e privados valorizaram a Região Administrativa Ceilândia que manifesta essa mudança de conteúdo.

O sistema de transporte urbano de passageiros por trens em linhas, geralmente subterrâneas no Distrito Federal é composto por 29 estações, das quais 24 estão em funcionamento. Toda a via tem extensão de $42,38 \mathrm{~km}$ e liga a região administrativa de Brasília à de Ceilândia. A operação iniciou em 2001 com o trecho que liga Samambaia a Taguatinga, Águas Claras, Guará e Plano Piloto e somente em 2006 alcançou Ceilândia com a operação no trecho que liga Taguatinga e Ceilândia Sul, passando pela estação Centro Metropolitano. Em 2007 as obras avançaram levando o METRÔ-DF até a estação terminal Ceilândia, localizada em Ceilândia Norte. 
Em 2008 é inaugurada as quatro estações restantes da Ceilândia: Guariroba, Ceilândia Centro, Ceilândia Norte e Terminal Ceilândia. Está em andamento a expansão de duas novas estações e mais $2,5 \mathrm{~km}$ de via em Ceilândia conforme Imagem 12: Linhas e estações do METRÔ-DF.

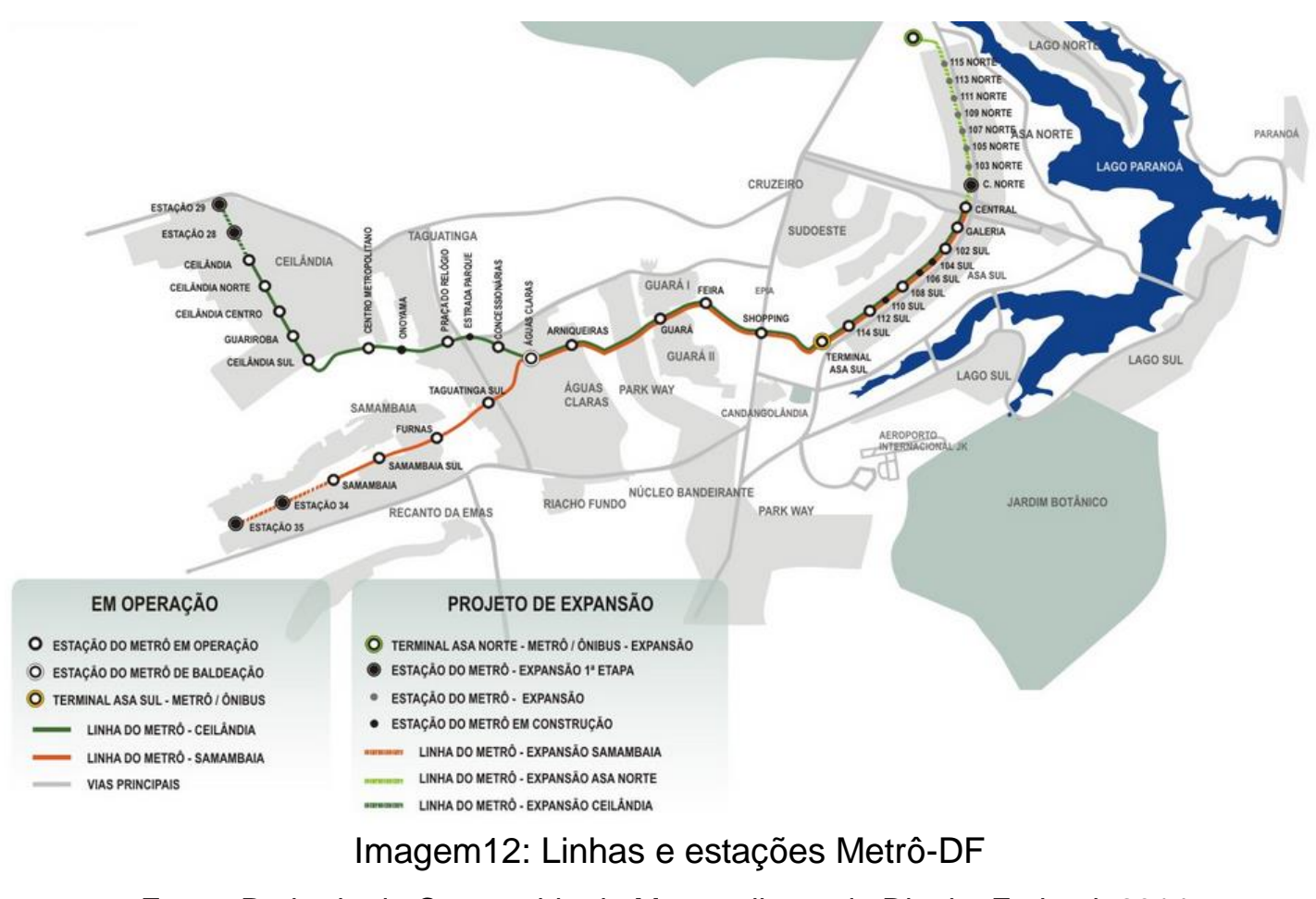

Fonte: Retirado de Companhia do Metropolitano do Distrito Federal, 2014.

Em 2013 é inaugurado na Avenida Hélio Prates - QNM 34, Área Especial 1 M-Norte Ceilândia, o complexo comercial que conjuga trabalho, lazer e diversão. Shopping center e torre de escritórios, o Shopping JK, com cerca de cento e dez lojas das quais ao menos $30 \%$ são franquias encontradas em shopping center de classe média do plano piloto. A área de alimentação é formada por trinta lojas de maioria franquias de fast food nacionais e internacionais. Ainda, possui seis salas de cinema adaptadas à acessibilidade, com equipamentos de última geração e 5 pavimentos de garagem com sistema de segurança de última geração. O funcionamento do shopping center é de segunda a sábado das 10 as 22 horas e domingo das 14 as 22 horas. 
2.2.1 Histórico da Feira Permanente de Ceilândia/DF - Estudo de Caso

A Feira Permanente da Ceilândia nasceu informalmente como aglomeração de barracas em 1971 a partir da iniciativa de moradores da cidade recém-criada. Em 1972 a feira foi legalizada e organizada em bancas. Em 1984 foi inaugurada oficialmente a primeira estrutura na Avenida Hélio Prates, que liga Taguatinga e Ceilândia.

Inaugurada oficialmente em 1984, a Feira Central da Ceilândia, ao longo dos anos, se tornou um símbolo cultural e turístico da cidade que lhe dá o nome. A feira, na verdade, começou a funcionar ainda no início da década de 70, mas em três pontos diferentes (no centro de Ceilândia; no lugar onde hoje fica a Feira da Guariroba/P Sul e na extinta Vila do Pedrosa, na região norte da cidade) até que os feirantes conseguiram se organizar no centro da cidade. Durante quase dez anos eles trabalharam de forma precária, até que em 1982 se iniciou a construção do que é hoje um dos principais pontos turísticos de Ceilândia. (ALMEIDA, 2012)

Ainda segundo Almeida (2012) a feira da Ceilândia, iniciou com cerca de cem bancas que comercializavam temperos, animais vivos e abatidos e comida típica do Nordeste. Recebe destaque pela expressão cultural nordestina expressa pelos proprietários das bancas e nos transeuntes migrantes dessa região que vieram para a capital em busca de melhores condições de vida. A feira é tida como ponto de encontro e reencontro nordestino.

A feira Permanente da Ceilândia, como também é conhecida a Feira Permanente da Ceilândia é inaugurada, no formato atual, em 1984, possui quatrocentos e sessenta boxes dos mais diversos segmentos, sendo cerca de trinta deles ocupados pelo segmento que prepara e comercializa alimentos típicos nordestinos.

A feira está localizada em Ceilândia Centro, na Avenida Hélio Prates, CNM 2 Área Especial, próxima a Caixa d'Água que fica a 3,5 quilômetros a pé ou 18 minutos de ônibus do novo Centro Administrativo do Distrito Federal, conforme Imagem 13, e a cerca de um quilometro do recém inaugurado JK Shopping. A Caixa d'Água foi erguida em 1973 no local onde foi fixada a pedra fundamental de Ceilândia, é monumento histórico da cidade e símbolo representativo de Ceilândia. 


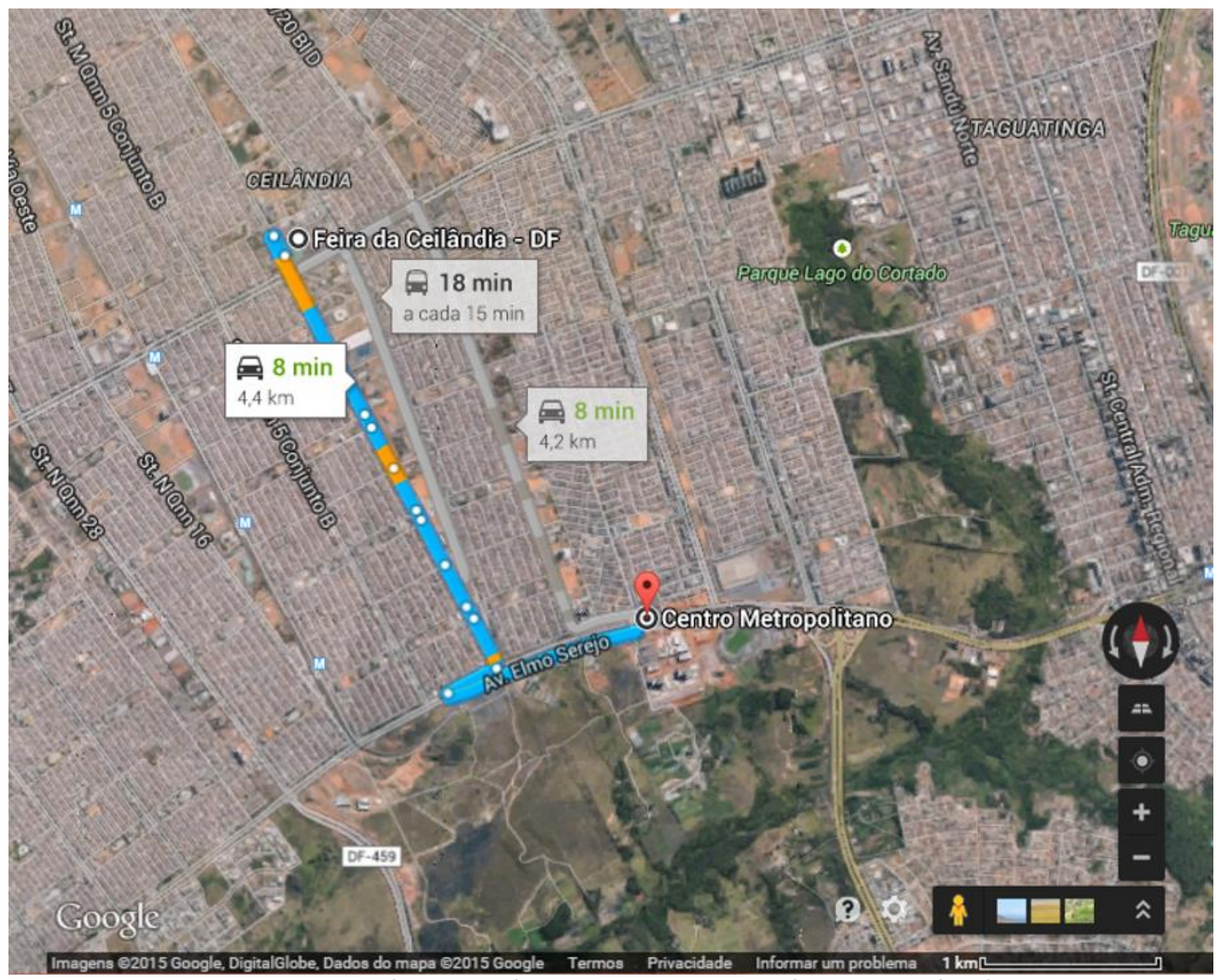

Imagem 13: Distância do Centro Metropolitano à Feira da Ceilândia

Fonte: Imagem adaptado pela pesquisadora em fevereiro de 2015.

Em 2012 o então governador Agnelo Queiroz sanciona a Lei 4748/2012 que foi celebrada pelos feirantes por dar permissão de uso da banca por quinze anos, podendo ser prorrogada por igual período e possibilitar a transferência aos herdeiros. As melhorias pós Lei 4748/2012 do projeto de lei 639/2011 para a feira Central da Ceilândia foram: rampas de acessibilidade, reforma e recapeamento do estacionamento, construção da sede da administração da feira e revitalização dos banheiros.

A feira é administrada pelo serviço de Feiras da RA IX e possui uma associação, a Associação dos Feirantes da Feira Central de Ceilândia (ASFEC). A Associação é presidida pelo senhor Francisco das Chagas Nogueira há 17 anos, o Sr. França, como é conhecido, feirante há 40 anos, seguindo uma tradição familiar.

Apesar das inúmeras ações de concorrentes a feira mantem seu espaço no cenário do comércio local se destacando como ponto tradicional. Seu primeiro grande 
concorrente foi a Feira dos Goianos, localizado na mesma avenida, porém já nos limites da RA Taguatinga. A Feira dos Goianos foi inaugurada em 1998 e se destaca pelo comércio de confecções. O segundo concorrente foi o Shopping Popular, inaugurado em 2006 como espaço que abrigaria o comércio ambulante, irregular, das ruas da Ceilândia. Está localizado há duas quadras da feira e possui uma estrutura com 837 boxes. O terceiro, o Shopping JK, está localizado na mesma avenida e foi inaugurado em 2013.

Em relação a concorrência, Sr. França declarou em entrevista ao Jornal Laboratório da Faculdade de Comunicação da Universidade de Brasília em novembro de 2013: "Os shoppings e comércios têm que abrir, comércio legal não prejudica ninguém, é só saber conviver com ele. A gente que é de feira conquista o cliente. Durante a semana, passam por aqui de sete a oito mil pessoas e, no final de semana, são de dez a onze mil" (FIDELIS, 2013).

\subsubsection{Relato Etnográfico da Feira da Permanente da Ceilândia}

A feira pode ser observada de forma diferenciada: um olhar de fora, e outro olhar por dentro. Revela a existência não apenas da história de uma comunidade, mas a trama histórica de parcela da humanidade em um micro cosmo, pois ali se expressam micro poderes, a política local, as formas de sobrevivência construídas na possibilidade histórica e as relações socioculturais de um lugar de hibridização. Revela a existência dos conflitos do mundo contemporâneo. Longe de ser um ponto fixo no mapa repleto de histórias individuais, a feira Permanente da Ceilândia possui histórias que se interligam para se constituir como um espaço de compartilhamento de vidas.

Adentrar a feira Permanente da Ceilândia com o intuito de desvelar o espaço com um olhar etnográfico visa explorar a subjetividade de uma realidade social complexa, onde seus atores constroem de forma concomitantemente suas histórias individuais e coletivas.

A investigação resultou em frutos de ordem particular e profissional, pois ao transpor a soleira de entrada não mais como frequentadora mas como pesquisadora, um novo e vasto universo se abriu. 
Desempenhei uma tática de aproximação antropológica: a frequência e a regularidade (NIKODIMOV, 2011).

Foram muitas as vezes que frequentei à feira apenas para estar na feira. Andei, adquiri itens que estavam em minha lista de compras cotidiana, passeei, conversei, vi e me fiz ver, e apenas quando me senti confortável e familiarizada para adentrar aquela realidade foi que iniciei o mapeamento das bancas e as entrevistas com feirantes e frequentadores.

O período de imersão, para mim e para os atores pesquisados, resultou em uma relação de confiança entre pesquisadora e entrevistados. A hospitalidade, forjada ou não, permitiu com que dados e informações fossem coletados. As conversas desviadas, e as questões silenciadas, indicaram os limites, e também muitas respostas, do que perguntar.

Partindo do princípio que a gastronomia, como a degustação de um prato exige a utilização dos sentidos fundamentais, e, por eles a memória degustativa é ativada utilizei dos cincos sentidos fundamentais para minhas observações: a audição, o olfato, o paladar, o tato e a visão e da própria memória para construir as evidencias que foram desvelando as teias estruturantes da hospitalidade, da comensalidade e da identificação coletiva que permeia a convivência na Feira Permanente da Ceilândia.

Falas sobre a visão:

Ao nos depararmos com a entrada principal visualiza-se os dizeres:

"Seja Bem Vindo! Feira Central Ceilândia" conforme Imagem 14.

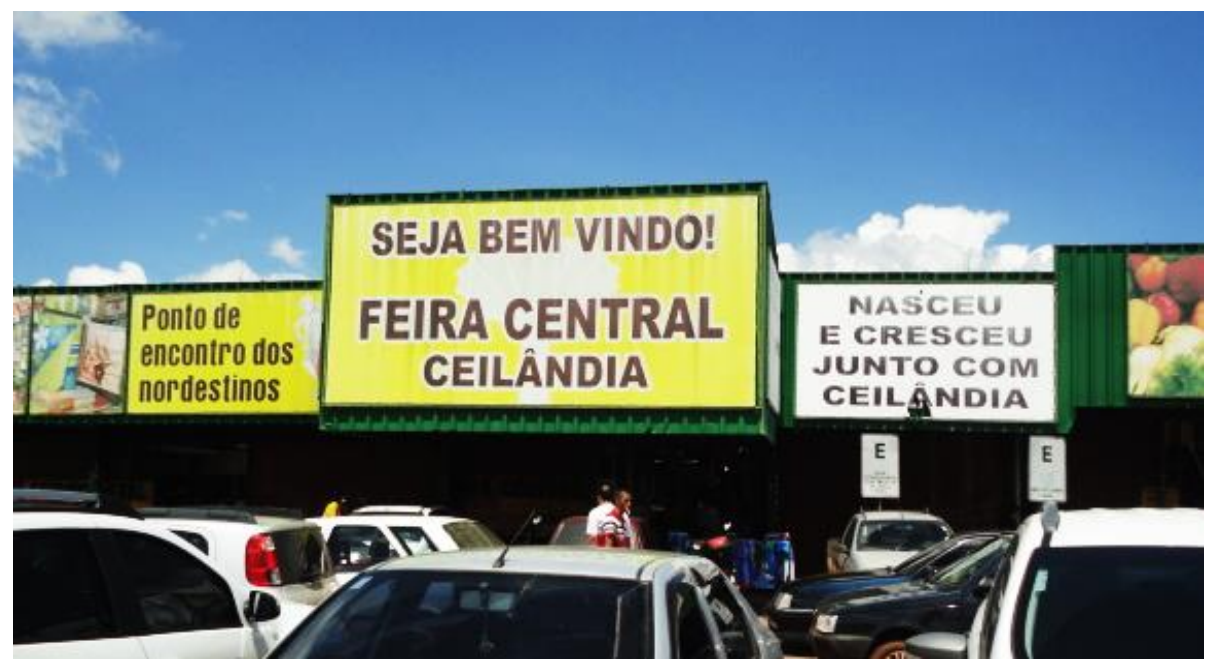

Imagem 14: Faixada da Feira da Ceilândia

Fonte: Imagem registrada pela pesquisadora em 27 de fevereiro de 2015. 
A saudação de boas-vindas, contato visual inicial, já fornece indícios que as relações pretendem menor impessoalidade que em outros centros de comércio com suas fachadas de anúncios luminosos (imagens 15 e 16 respectivamente).

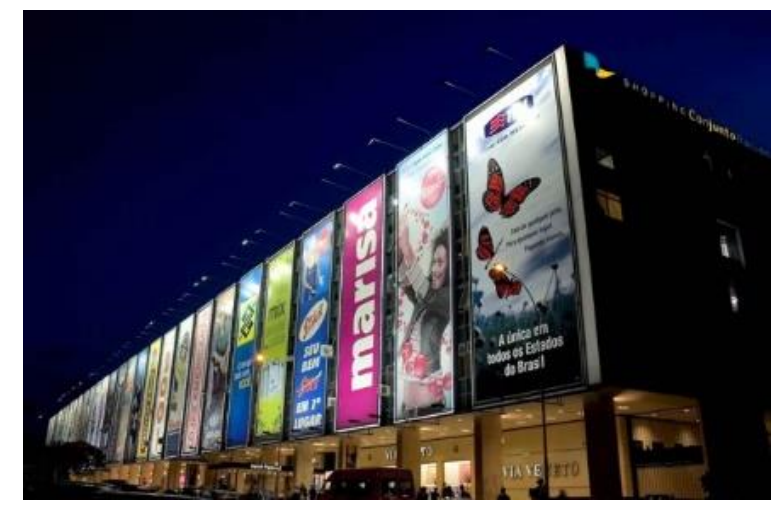

Imagem 15: Conjunto Nacional

Fonte: BR Shopping, 2014.

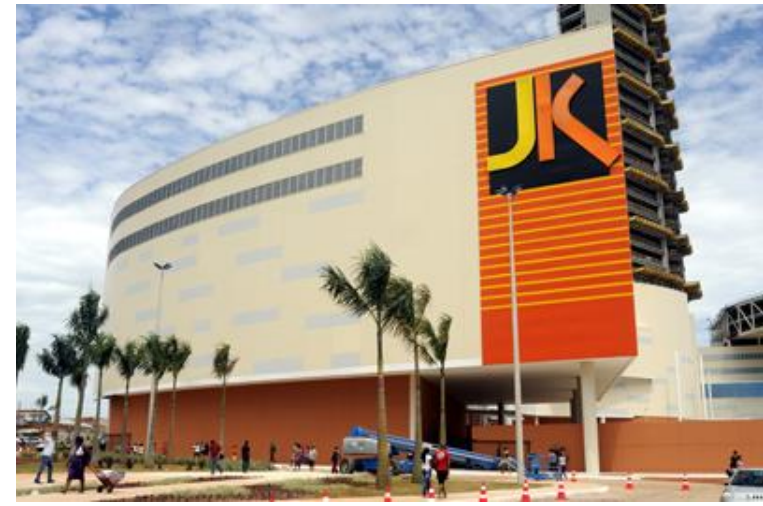

Imagem 16: JK Shopping

Fonte: Jornal de Brasília, 2014.

A estrutura física de ferro, coberta com telhas de amianto abriga as cerca de quatrocentas bancas que estão dispostas organizadamente em sete corredores longitudinais denominados por letras, A, B, C, D, E, F e G e onze corredores perpendiculares a esses.

Abriga a sede da Associação dos Feirantes, localizada na mesma área da cabine de som, banheiros feminino e masculino, caixas eletrônicos, dois provadores de roupas, um posto da polícia militar e outro de fiscalização.

De corredores estreitos, se comparados aos shopping centers, as bancas possuem rede elétrica individual.

As bancas de confecção em geral, calçados, utensílios e temperos expõem seus produtos acomodando-os nas estruturas externas das bancas deixando-os ao alcance dos clientes. Os vendedores posicionam-se a frente da banca para captar e atender os frequentadores. 


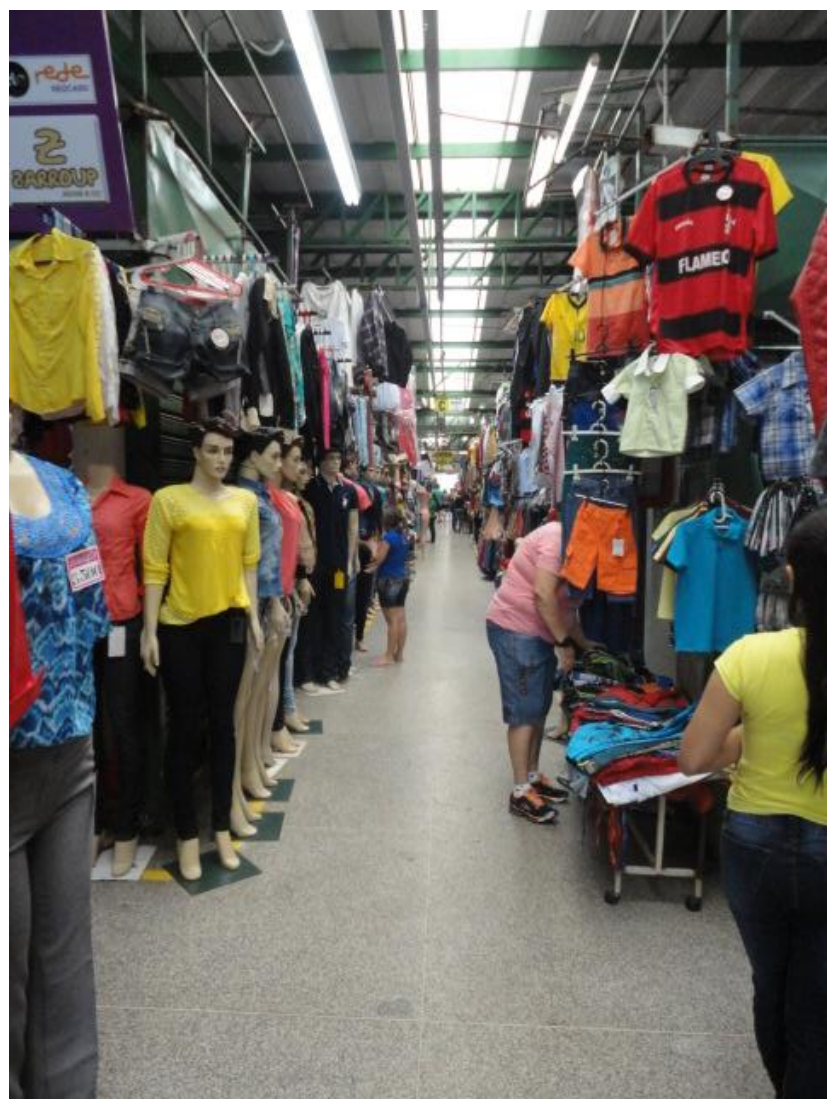

Imagem 17: Bancas de Confecção

Fonte: Imagem registrada pela pesquisadora em 25 de março de 2015.

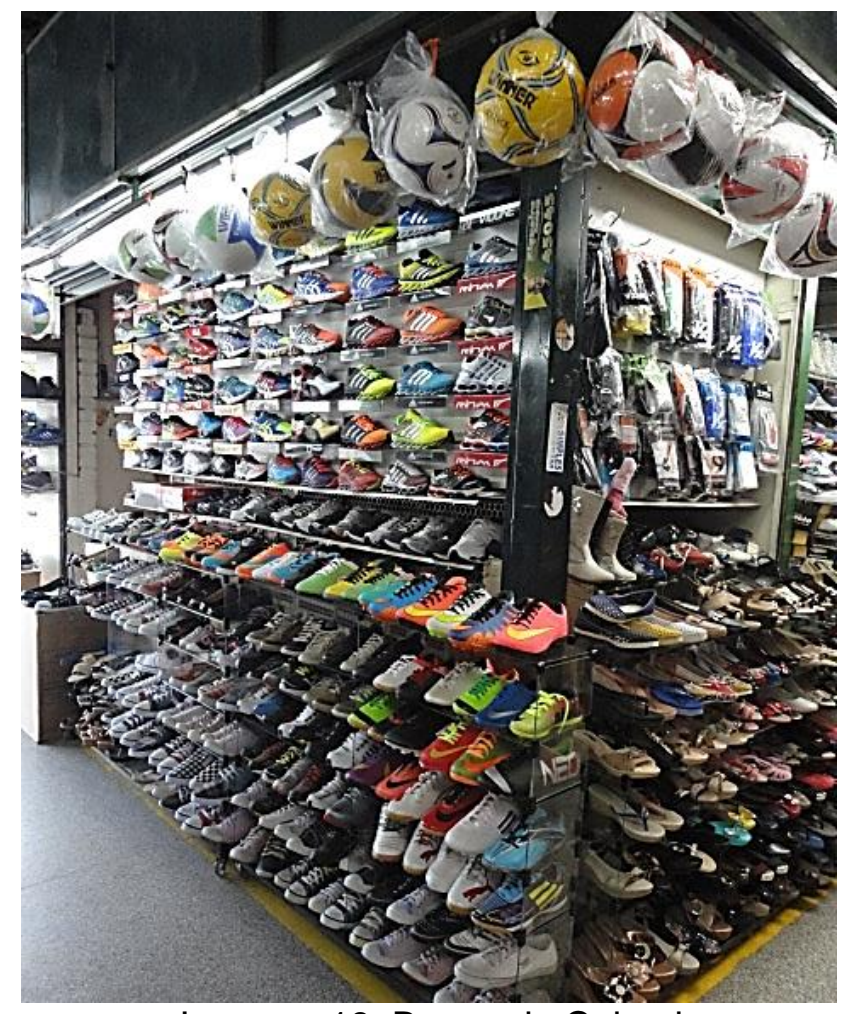

Imagem 18: Banca de Calçados

Fonte: Imagem registrada pela pesquisadora em 25 de março de 2015. 


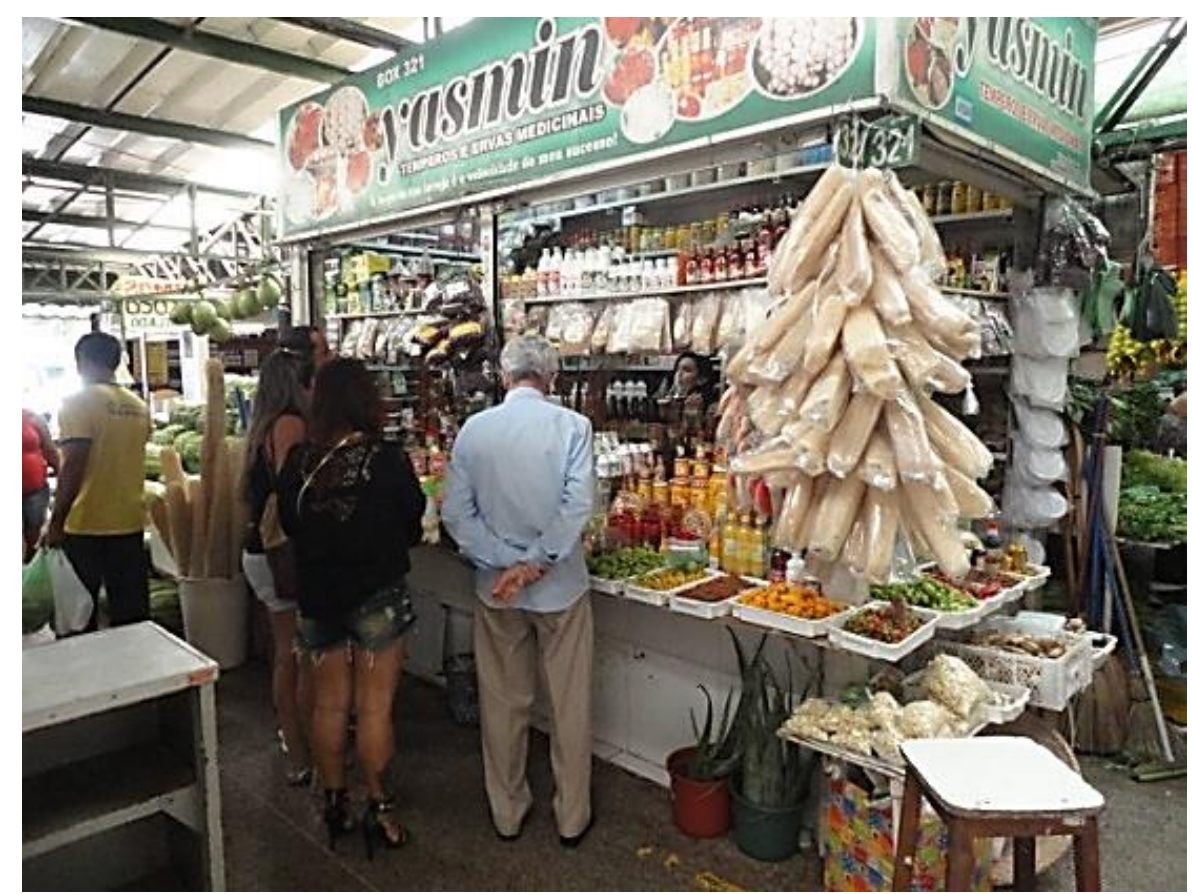

Imagem 19: Banca de Temperos

Fonte: Imagem registrada pela pesquisadora em 29 de março de 2015.

As bancas que comercializam peixes, carnes e aves expõe os produtos em vitrines refrigeradas. Já as bancas de queijos e doces utilizam vitrines refrigeradas para expor os itens que necessitam de controle de temperatura, filó para proteger alguns itens de voadores e recipientes com tampa incolor para expor doces e biscoitos conforme Imagem 20.

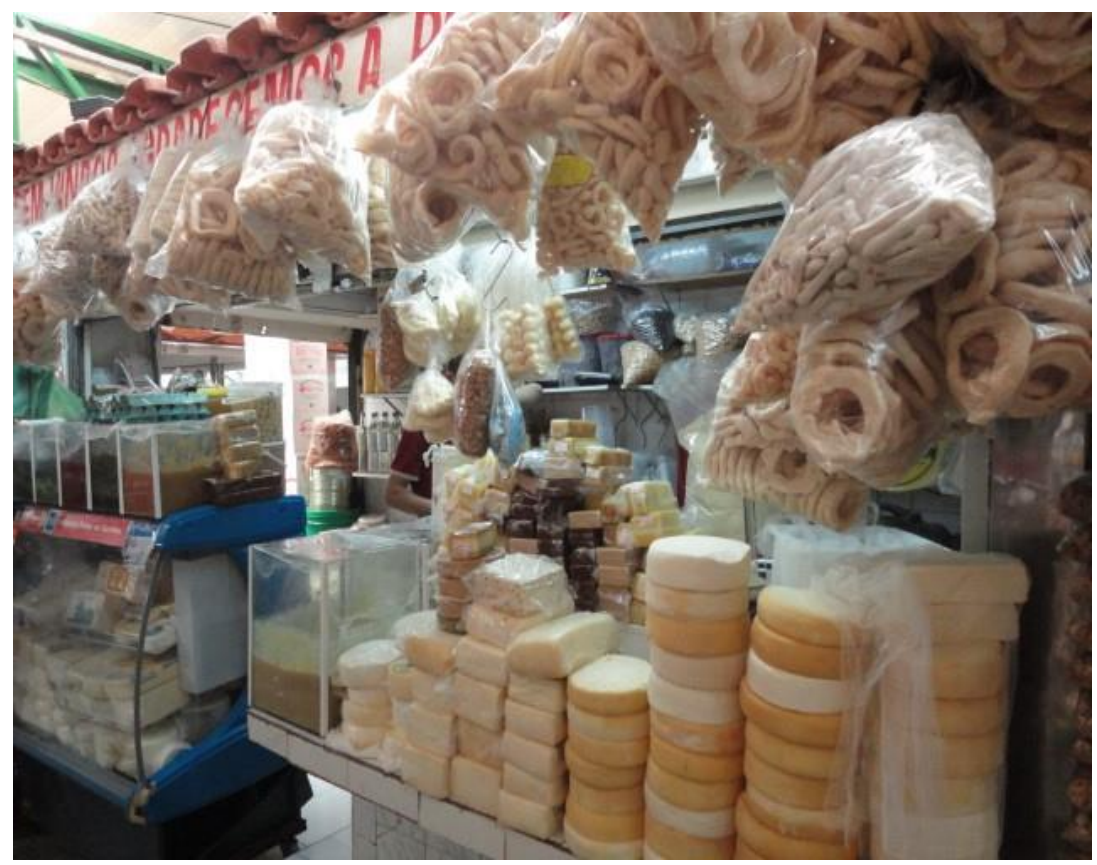

Imagem 20: Banca de Queijos e Doces

Fonte: Imagem registrada pela pesquisadora em 26 de março de 2015. 
Os hortifruti são expostos e acessíveis aos clientes e ficam dispostos conforme o gênero (imagens 21 e 22).

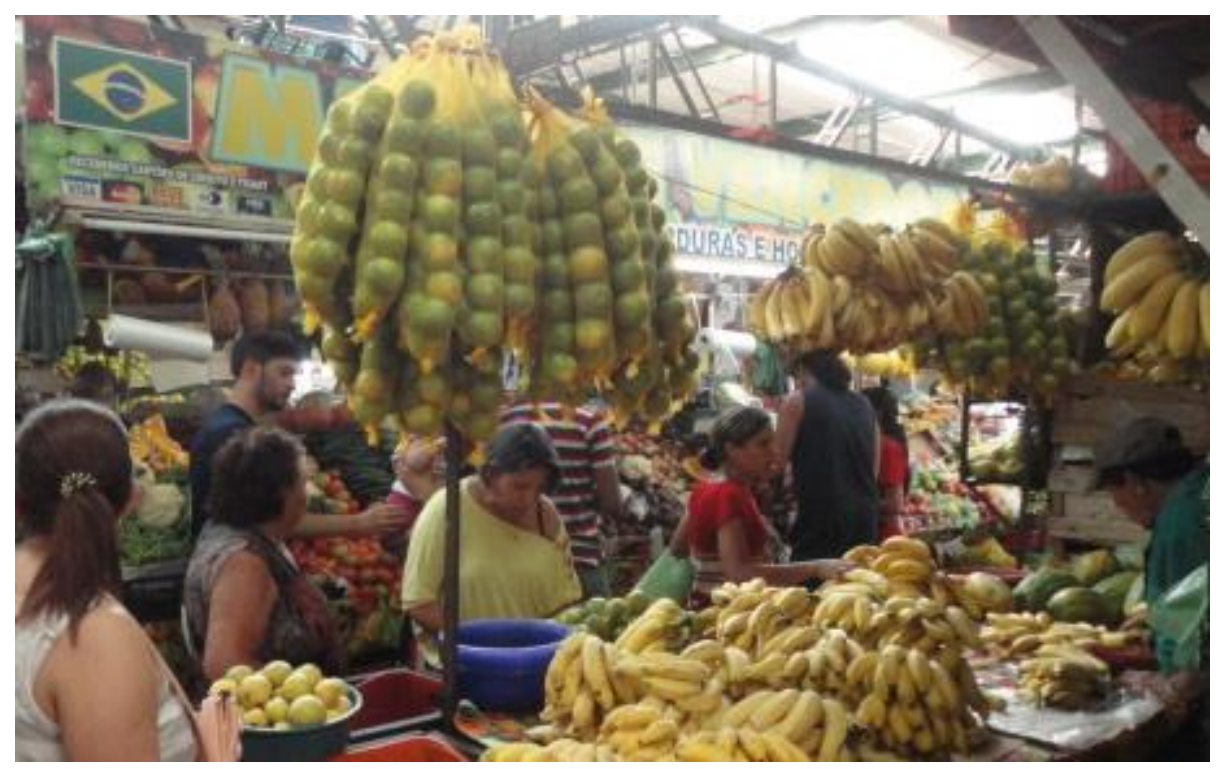

Imagem 21: Banca de Hortifruti

Fonte: Imagem registrada pela pesquisadora em 29 de março de 2015.

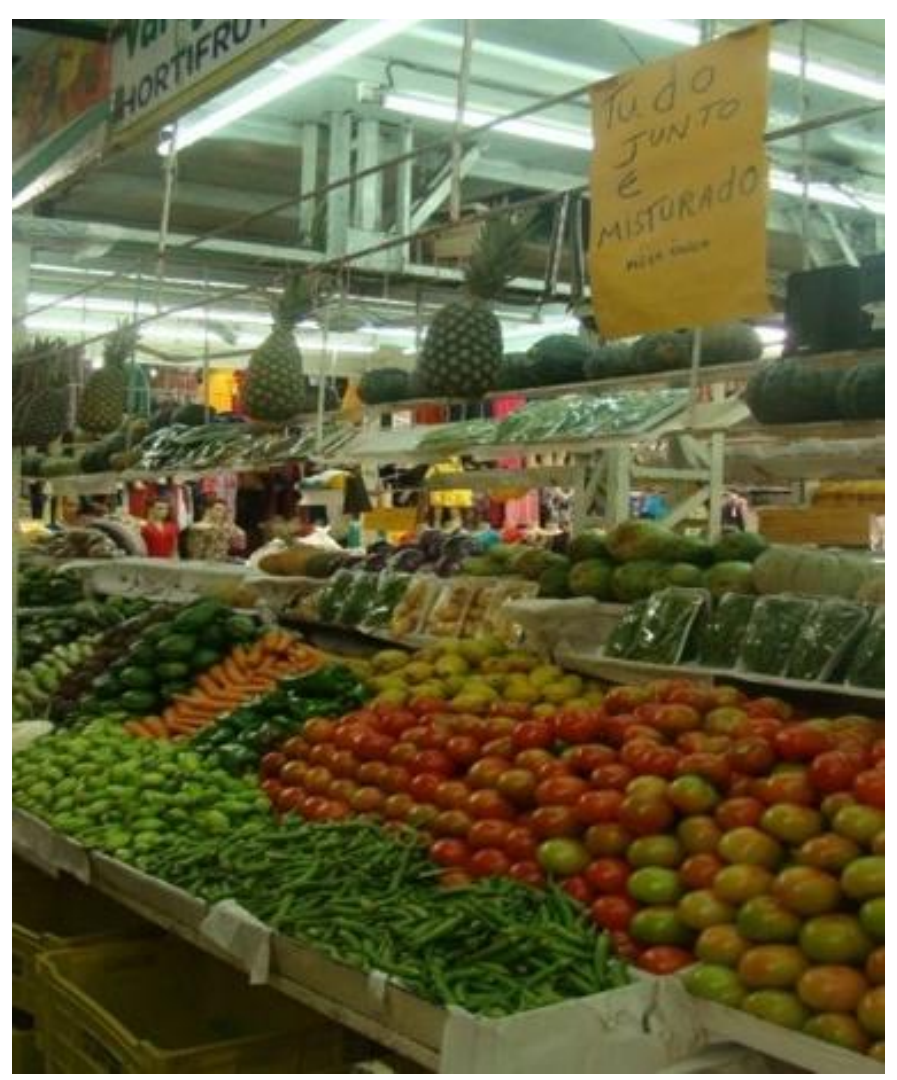

Imagem 22: Banca de Hortifruti

Fonte: Imagem registrada pela pesquisadora em 26 de março de 2015. 
As bancas que comercializam cereais e grãos secos organizam seus produtos em sacas e prateleiras conforme Imagem 23.

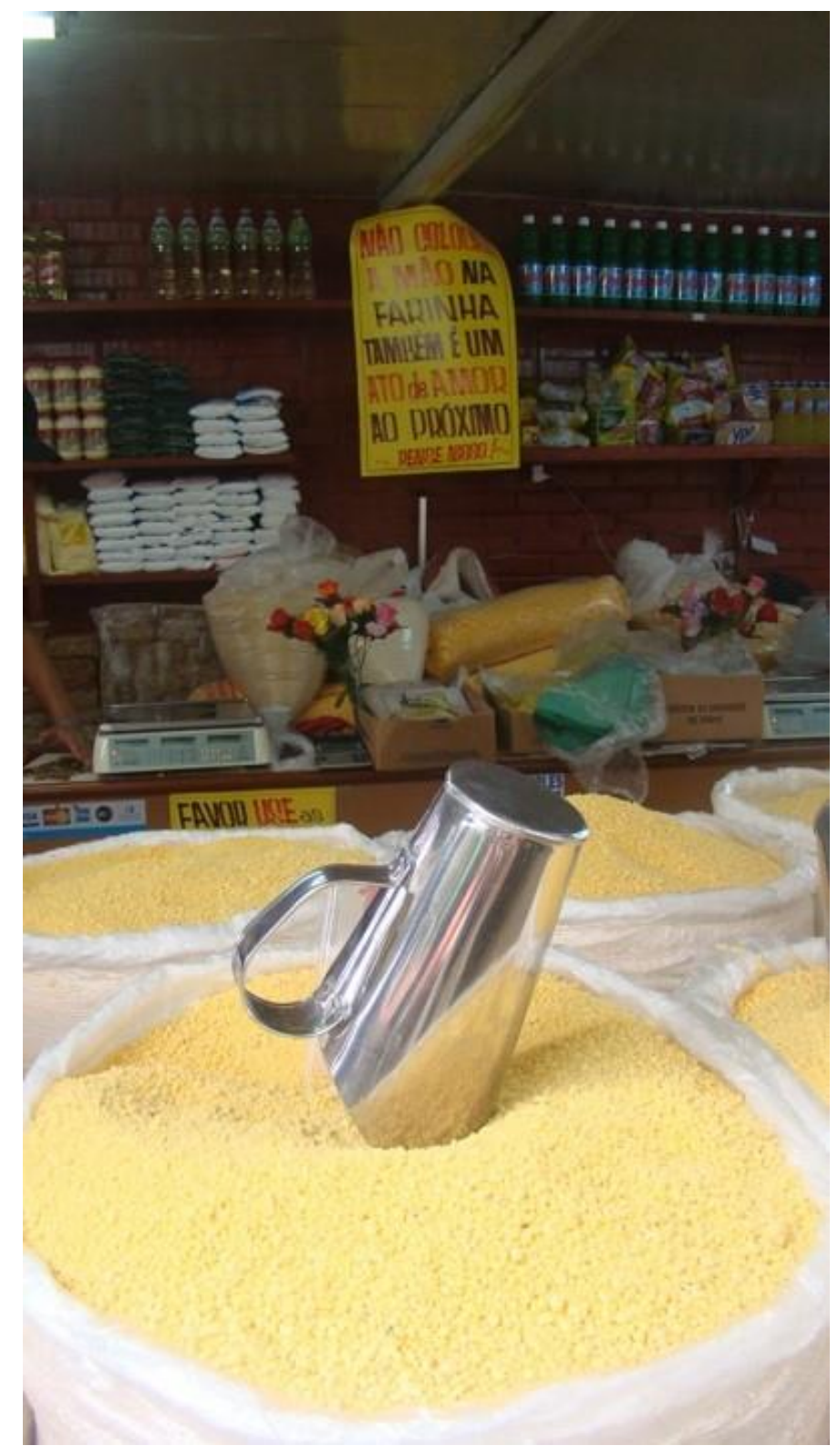

Imagem 23: Banca de Secos e Cereais

Fonte: Imagem registrada pela pesquisadora em 25 de março de 2015.

As bancas que preparam e comercializam alimentos e bebidas são divididas em dois tipos, lanches e comida típica nordestina. 


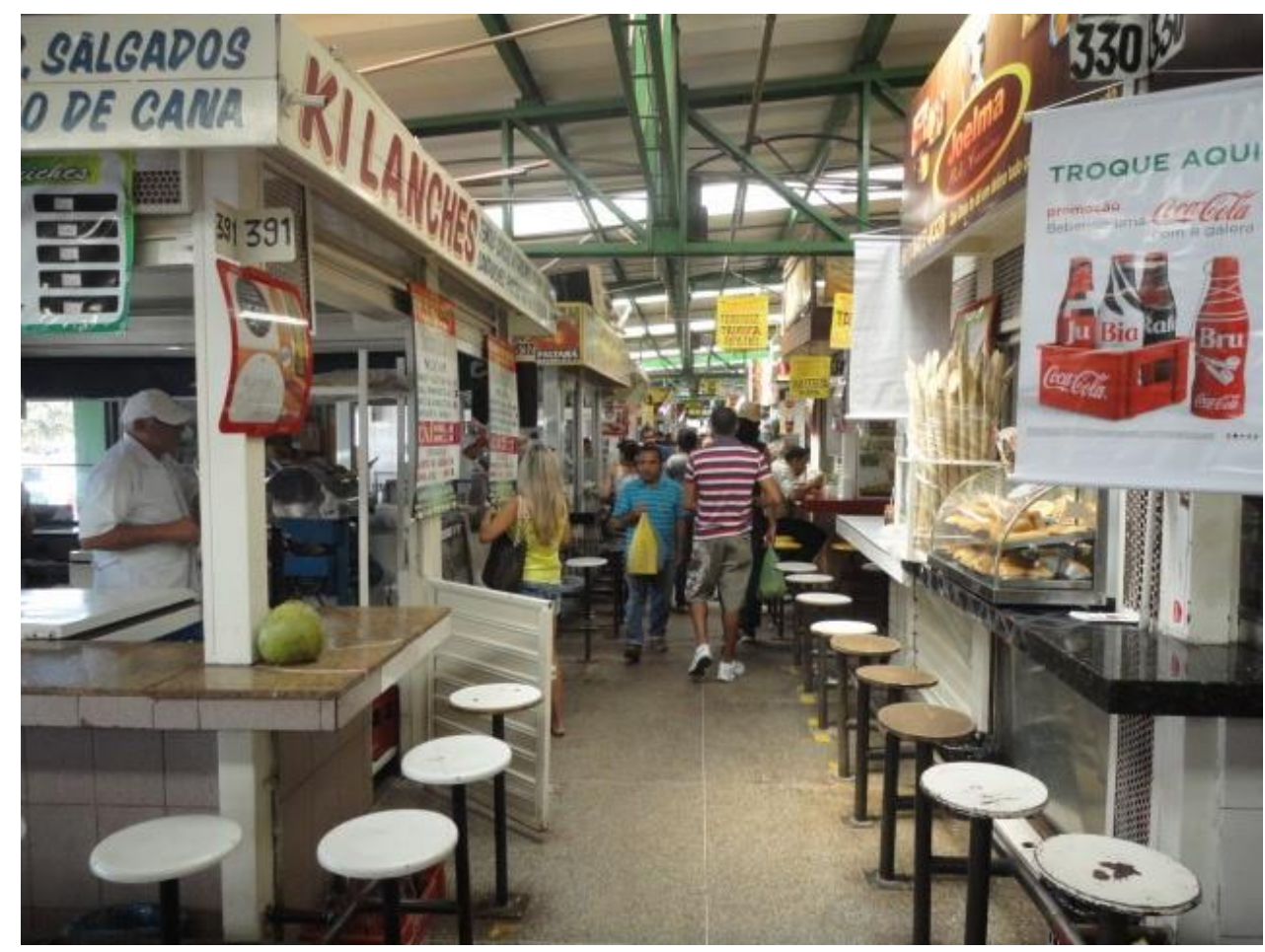

Imagem 24: Bancas de Alimentação

Fonte: Imagem registrada pela pesquisadora em 25 de março de 2015.

As bancas de alimentação concentram-se na extremidade da feira, voltado para a Avenida Hélio Prates. Dispostas lado a lado voltadas para a rua, o que facilita a infraestrutura de água e esgoto. Oito bancas, uma de comida nordestina e as outras de lanche, ficam no corredor subsequente e uma do outro lado da feira como pode-se observar pelo Croqui 1. 


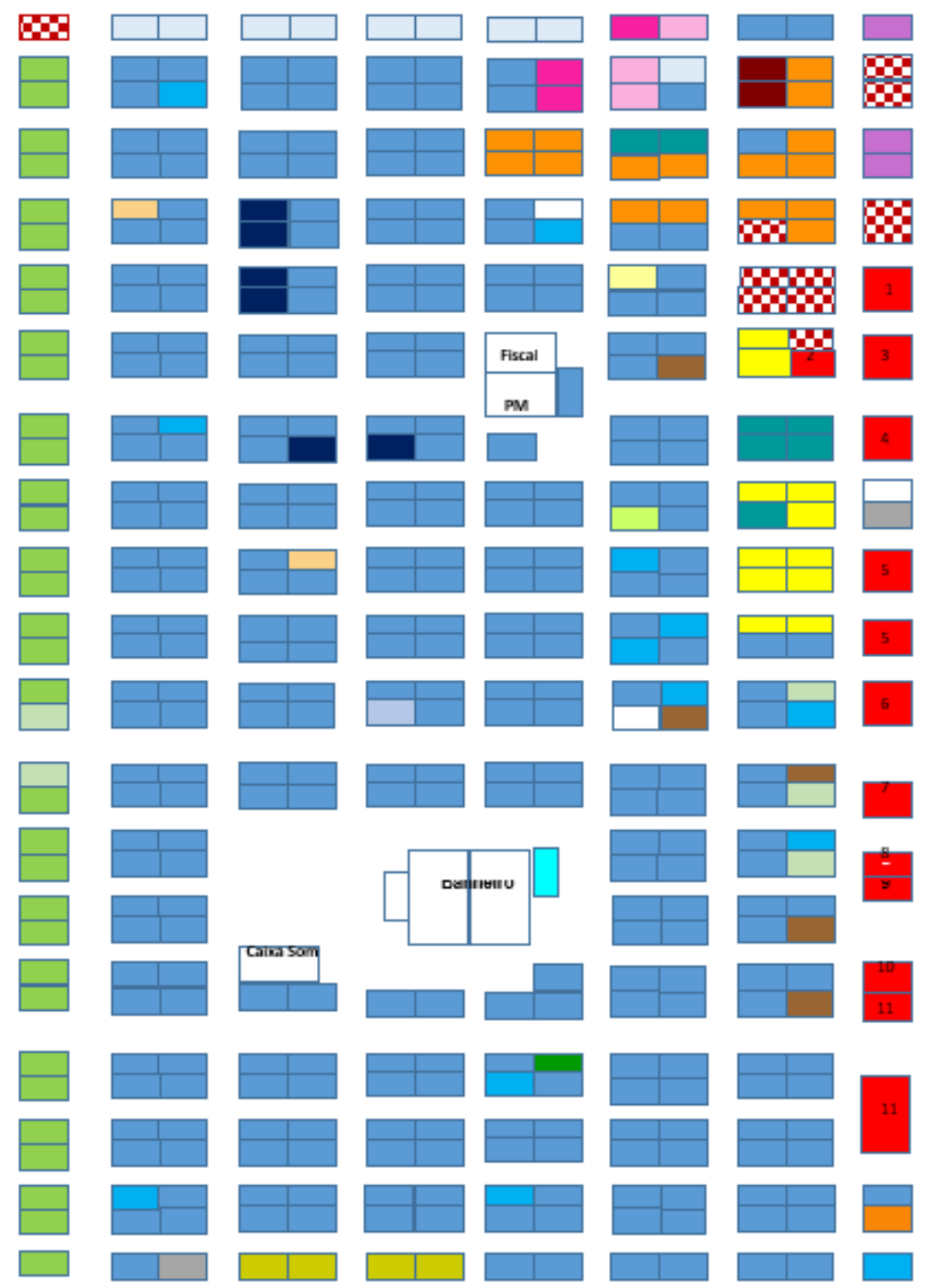

\begin{tabular}{|c|c|c|c|c|}
\hline$\square$ Confecção & $\square$ Confecção Infantil & $\square$ Calçado & $\square$ Artigos de Viagem & $\square$ Moda Intima \\
\hline$\square$ Moda Praia & Cama/Mesa/Banho & Embalagem & $\square$ Utensílios & $\square$ Brinquedos \\
\hline$\square$ Tabacaria & Bolsas e acessórios & $\square$ Tapeçaria & $\square$ Perfumaria & $\square$ Temperos \\
\hline 四 Lanche & $\square$ Peixaria & Aves Vivas & $\square$ Aves Resfriadas & açougue \\
\hline$\square$ Hortifruti & $\square$ Queijos e doces & $\square$ Secos & Alimentos e Bebidas & $\square$ Bomboniere \\
\hline
\end{tabular}

$\begin{array}{lll}\text { 1- Come Bem } & \text { 2- Esquina Sabor do Nordeste } & \text { 3- Estação Nordeste } \\ \text { 4- Galega e Buga } & \text { 5- Kome in Pé } & \text { 6- Rei do Mocotó } \\ \text { 7- Banca do Carlão } & \text { 8- Banca da Tati } & \text { 9-Sem Nome } \\ \text { 10- Sem nome } & \text { 11- Banca da Galega } & \end{array}$

Croqui 1: Feira Permanente da Ceilândia

Fonte: Croqui elaborado pela pesquisadora 
Ainda representada no croqui estão numeradas e indicadas de vermelho as bancas que preparam e comercializam pratos típicos do Nordeste. Visualmente são identificadas treze bancas desse tipo pois algumas delas ocupam duas e até três bancas que são:

- Barraca Come Bem,

- Esquina Sabor Nordeste,

- Estação Nordeste,

- Galega e Buga,

- Kome in Pé,

- Rei do Mocotó,

- Banca do Carlão,

- Banca da Galega;

Três bancas não identificam os nomes em suas fachadas, a conhecida como "Bancada Tati", uma que é extensão da Kome in Pé e outra que é a continuação da Banca da Galega. Duas outras identificam-se apenas pelos números, 408 e 409 respectivamente. O que soma onze bancas de comida nordestina.

A Banca da Galega é a maior dessas bancas, ocupa o espaço de três barracas contíguas e mais uma em frente. As demais bancas ocupam o espaço de uma ou duas barracas e a Banca do Carlão possui área superior, em metros quadrados, de uma banca comum da feira.

As bancas que preparam e comercializam alimentos e bebidas possuem estruturas físicas similares. Com balcão e bancos fixos ao chão. Preparam os alimentos no mesmo ambiente que os expões e comercializam conforme Imagem 25.

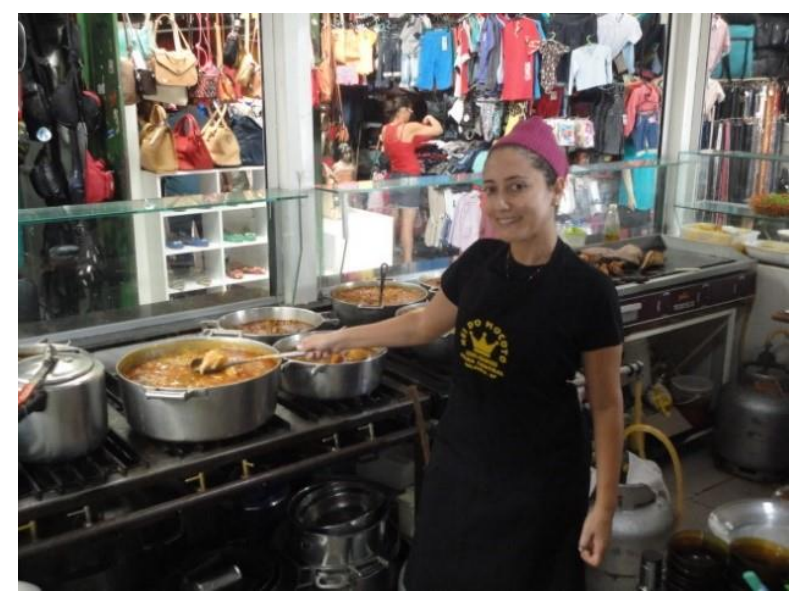

Imagem 25: Banca Rei do Mocotó

Fonte: Imagem registrada pela pesquisadora em 16 de dezembro de 2014. 
Patrícia Furtado, esposa de Francisco, "dono" da banca Rei do Mocotó relatou que ele, brasiliense, filho de nordestinos, tem seu nome chamado por seus clientes que buscam atendimento em sua banca.

A separação entre a área interna (cozinha) e externa (balcão de atendimento) se dá por um vidro de cerca de sessenta centímetros de altura, instalado sob o balcão, o que possibilita ao comensal a visualização de todo o processo de manipulação dos alimentos além de contribuir para a proximidade feirante/frequentador.

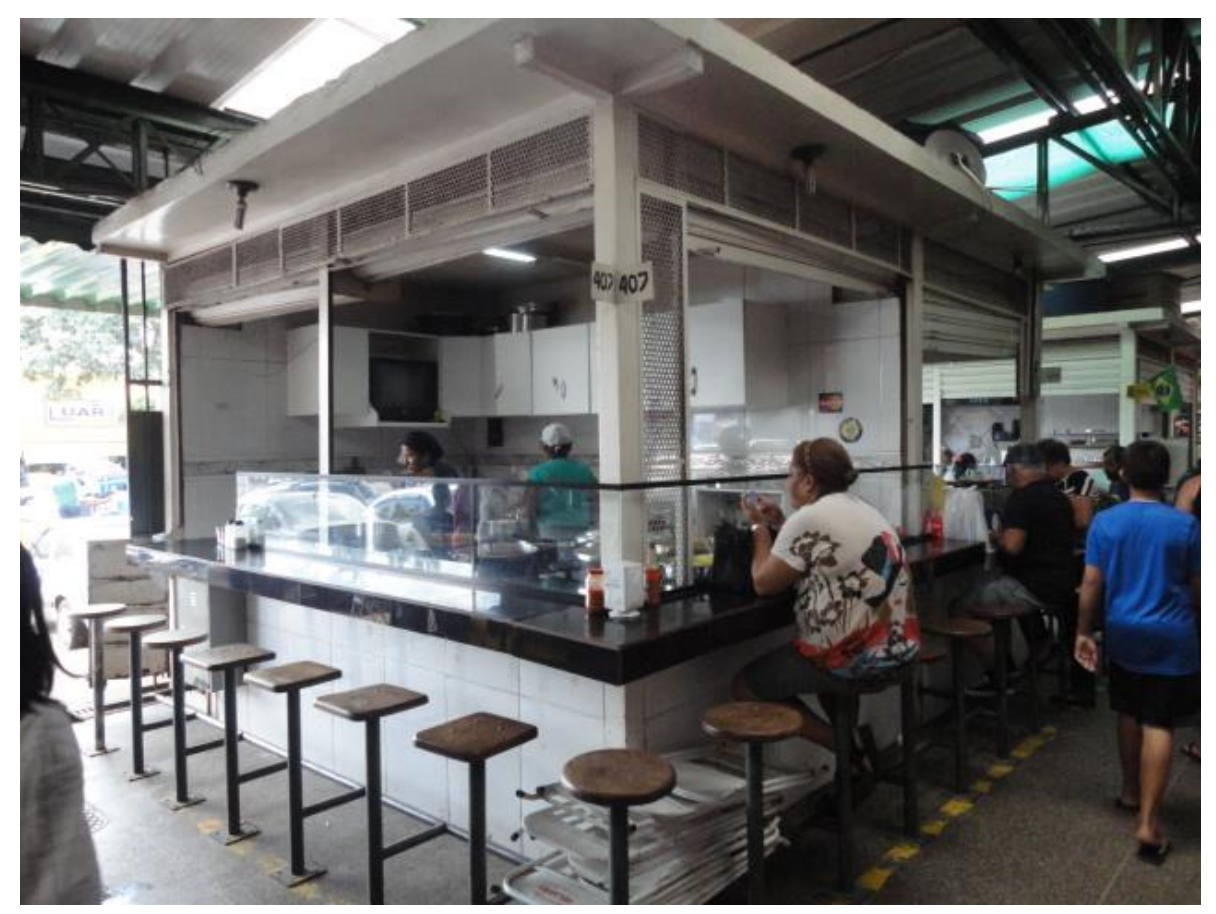

Imagem 26: Estrutura das Bancas de Alimentação

Fonte: Imagem registrada pela pesquisadora em 19 de novembro de 2014.

A visão de dentro da feira está representada nas imagens $27,28,29$ e 30 onde pode-se ver o estacionamento e outras formas de comércio que ocorrem nas imediações da feira.

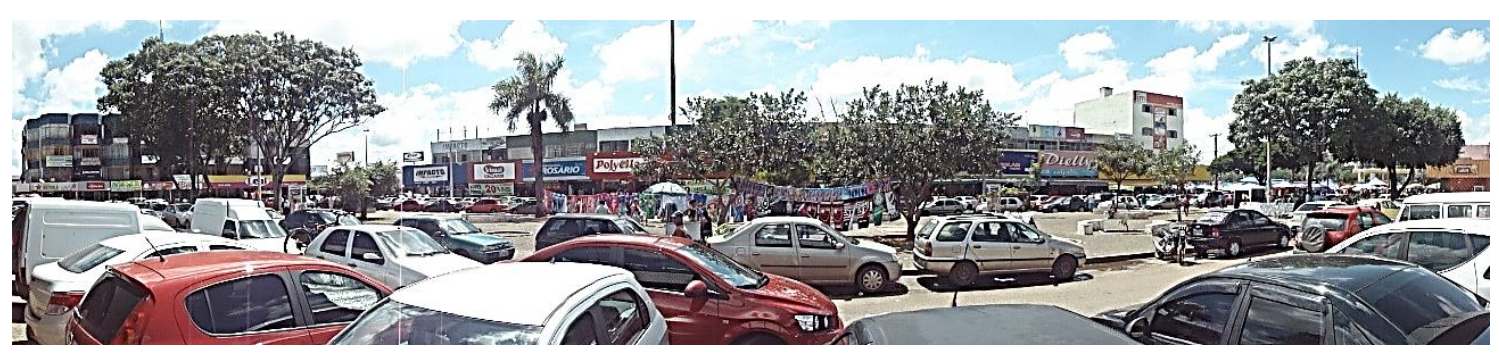

Imagem 27: Visão Lado Direito do Croqui da Feira

Fonte: Imagem registrada pela pesquisadora em 25 de março de 2015. 


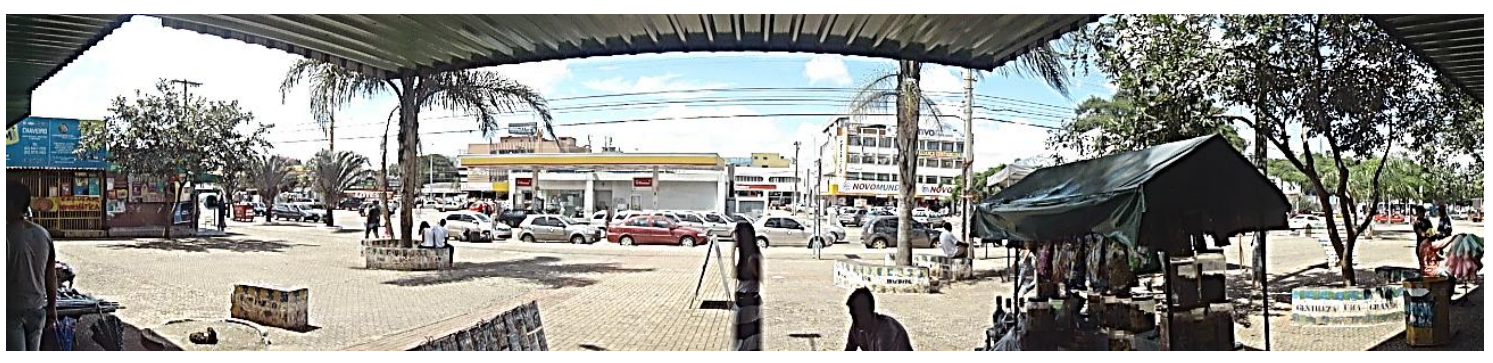

Imagem 28: Visão Lado Superior do Croqui da Feira

Fonte: Imagem registrada pela pesquisadora em 25 de março de 2015.

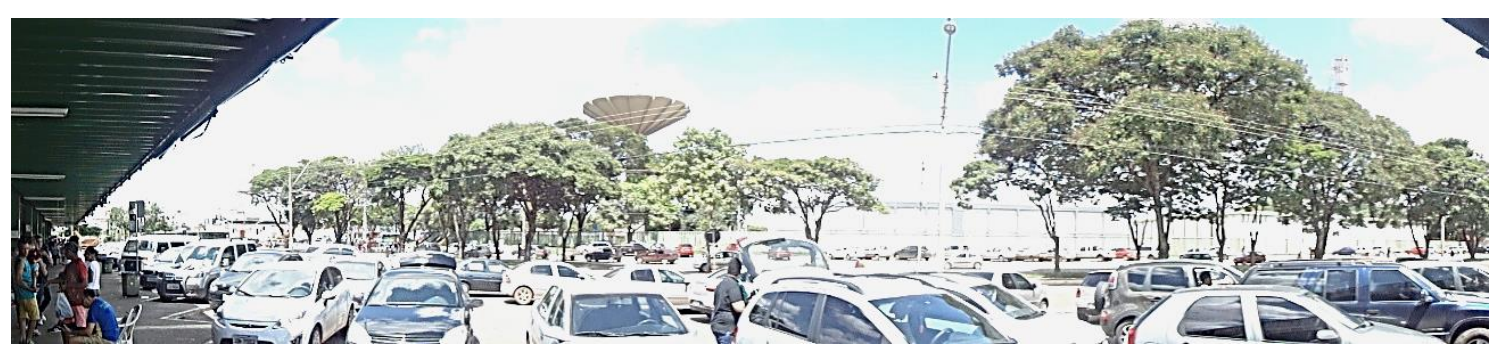

Imagem 29: Visão Lado Esquerdo do Croqui da Feira

Fonte: Imagem registrada pela pesquisadora em 25 de março de 2015.

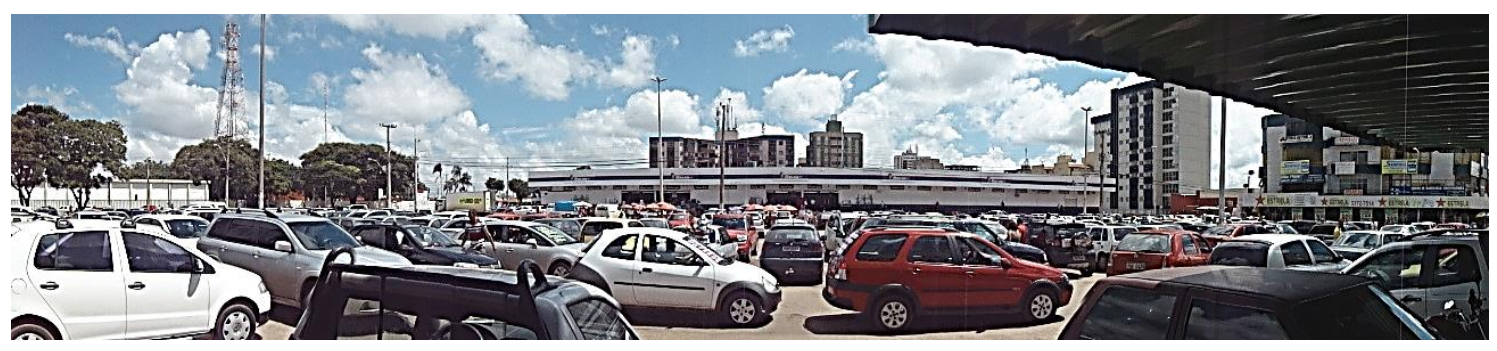

Imagem 30: Visão Lado Inferior do Croqui da Feira

Fonte: Imagem registrada pela pesquisadora em 25 de março de 2015.

Patrícia, da banca Rei do Mocotó, contou: "Antigamente haviam mesas e cadeiras dispostas na parte externa da feira, (do lado direito do Croqui 1), para que os clientes tivessem mais conforto. A retirada desse serviço foi imposta pela Administração Regional de Ceilândia e acatada pela Associação".

Hoje os clientes utilizam os bancos disponibilizados por cada banca ou comem em pé, com o prato na mão, aguardando vagar um dos poucos bancos.

Patrícia, em entrevista,16 de dezembro de 2014, relatou ainda, que a visão dos arredores da feira hoje está bonita, mas que era feia. As calçadas eram tomadas pelo comércio ambulante e poluíam o visual e acrescentou: "O governador limpou o local. Sei que alguns foram para o Shopping Popular, mas outros ficaram sem trabalhar". 
Em março de 2015 a realidade já havia se alterado.

Para a feirante Tatiana, em entrevista no dia 28 de março de 2015, o espaço "limpo em 2014" possibilitou a vinda de desocupados para a área:

A praça que antes era endereço de ambulantes e comércio informal, hoje é endereço de desocupados e consumidores de drogas ilícitas o que trouxe, segundo ela, pedintes para dentro da feira e insegurança à feirantes e frequentadores.

Para os usuários de transporte particular a feira conta com dois estacionamentos, um lateral e um na entrada principal. Seu Antonio, o guardador de carro que fica habitualmente no estacionamento da entrada principal da feira, irá cumprimentá-lo e zelar não apenas pelo automóvel, como também por seu condutor. Sabe a hora que você chega, com quem costuma ir e quanto tempo fica. Na chegada a feira, e na saída, sabia que encontraria com aquele senhor, e certamente teria que contar ou explicar porque cheguei cedo (ou tarde) e quem era aquela pessoa com quem estava. Para ele, o normal era eu ir só, mas nunca perguntou, na frente das pessoas que me acompanhavam quem elas eram. Não há coação por estar só, nem displicência por estar acompanhada, o que esse senhor imprime é um certo grau de intimidade. Demonstrava real interesse sobre minhas idas a feira e claramente se alegrava quando me via de volta em outros dias.

No período do Natal, quando o movimento da feira tradicionalmente aumentou, outros guardadores de carro se apresentaram no local guardando carro e vendendo produtos, de capa de chuva a bichos de pelúcia, mas Seu Antônio intervinha sempre que necessário. Em um desses dias pré-Natal, estacionar o carro foi atípico, não vi seu Antônio. Mais tarde ele me relatou que o rapaz que me direcionou à vaga estava embriagado e "teve que correr com o cabra, porque assim não dá." Isso me fez concluir que, mesmo de longe, ele estava administrando os guardadores de carro e seguia zelando e mantendo a acolhida aos frequentadores da feira. Findado o trabalho ele aguardava o pagamento, porém a relação de troca não era coativa, comum nesse tipo de serviço.

\section{Falas sobre a audição:}

$\mathrm{Na}$ feira existe um som ambiente, mas este não toca música. Hora ou outra o 
som que se ouve é a gravação da propaganda com dizeres sobre a Feira da Ceilândia como encontro de nordestinos.

A respeito do som o "Seu França", presidente da associação de feirantes da feira da Ceilândia, em entrevista fornecida a mim às 11:45 horas do dia treze de novembro de 2014 relatou com grande carga emocional que o som instalado e operado por ele há 18 anos foi o instrumento que criou o encontro de nordestino naquele local.

Seu França veio para o Distrito Federal em 1958 e quando retornou a cidade natal no Nordeste, dez anos depois, muitos amigos e conhecidos pediram notícias de seus familiares, Seu França então fez uma lista e ao retornar ao DF procurou os conterrâneos por diversos lugares, entre eles o edifício dos pioneiros, cartórios e cemitérios, porém muitas sepulturas não tinham identificação o que fez Seu França concluir que os que ele não havia encontrado, estavam mortos. Ao retornar ao Nordeste comunicava as famílias que o procurado havia falecido. Porém tempos depois esses conterrâneos dados como mortos eram vistos na feira da Ceilândia. Assim Seu França resolve chamar pelo auto falante do som da feira as pessoas que estavam desaparecidas de seus familiares. Com isso quando algum nordestino queria encontrar ou saber notícias de outro nordestino ia até a feira e pedia para chamar o desaparecido pelo som. Seu França o chamava até que ele ou alguém que sabia notícias dele se apresentava na cabine de som, local onde os encontros dos nordestinos se concretizavam.

Hoje, essa forma de encontro não é mais comum, visto que já se passaram 40 anos da vinda dos migrantes.

O caminhar pela feira revela a multiplicidade de variáveis que envolvem o espaço. A banca que vende calcinha sensual, toca no rádio música evangélica.

O feirante de bolsa e acessório mais que vender bolsas, desenrola extensa e intensa conversa com seus clientes. Nordestino, esse feirante está instalado há dez anos. Quando o conheci, um dia chuvoso de novembro de 2014, atendia uma senhora, nordestina. Enquanto ela escolhia uma carteira de dinheiro, conversavam sobre a estrada Brasília-Juazeiro. Eu, entre uma bolsa e outra, escutava as histórias da viagem de carro, do melhor percurso, da situação da via, da melhor parada para pernoite, da melhor e pior época para pegar a estrada, do tempo que passavam na estrada e no destino e de como essa viagem era feita antigamente, de ônibus, com o tempo curto, praticamente um bate-volta. Quando a senhora concluiu sua compra já 
estávamos todos conversando sobre o filho dela que agora mora no exterior estudando arqueologia.

A conversa com o vendedor de bolsas continuou. Ele contou sobre o sertão nordestino com uma riqueza de detalhes que faz qualquer um se transportar para a lá com facilidade. Ao descobrir que eu era "candanga" procurou nos diferenciar pela alimentação.

Disse: "eu como bode de todos os jeitos, vocês comem um boi inteiro se deixar. Não sei que mania é essa de vocês com boi". Tentei explicar a ele que "nós" gostávamos de boi, mas também de galinha. E então ele confidenciou que também gostava de galinha, inclusive da galinha com pequi (comida típica do Goiás). Ele nem se incomodou quando fui embora sem comprar nada, aliás, apesar das vendas não estarem muito boas desde o início desse ano, conforme me contou nenhum dos vendedores das bancas de calçados, roupas e utensílios domésticos fez cara feia por eu olhar os produtos e não comprar.

O falatório é constante e característico.

Os feirantes chamam seus possíveis clientes: "Fala freguesa! Está procurando o que hoje amiga! Vamos almoçar?"

Apresentam seus produtos, chegam perto para saber o que procura. Sempre sem invadir o espaço físico da banca vizinha. É uma linha (imaginária) que separa uma banca da outra. Sem rivalidade, apenas respeito. Mas basta ultrapassar a linha, entrando em outro território, que o ritual de chamamento novamente se inicia. Chamam, apresentam seus produtos, chegam perto para saber o que procura. $\mathrm{E}$ quando o cliente se vai, eles voltam a conversar entre si.

$\mathrm{Na}$ hora do almoço os feirantes de confecção em geral se reúnem na intersecção dos corredores, agrupam bancos e alimentam-se em marmitas conversando e brincando em si. Quando um cliente se aproxima eles rapidamente se dissipam cada um para a proximidade da banca em que trabalha em silencio, aguardando que o frequentador entre no espaço dele.

Quanto mais o relógio se próxima das doze horas maior o burburinho nas proximidades das bancas de alimentação:

"Vamos almoçar amiga? Hoje está especial! Quer que arrume um lugar pra você? Hoje você tem que comer aqui!" 
Laise, da banca Come Bem, e Patrícia, da banca Rei do Mocotó, relataram que identificam seus clientes como nordestinos através do sotaque. Ambas concordam que o nordestino tem linguajar e melodia específicos.

Falas sobre o paladar:

Todas as bancas que preparam e comercializam alimentos e bebidas na feira optam pelos pratos "tradicionais do Nordeste" como relatou Patrícia Furtado da banca Rei do Mocotó.

O Mocotó é o prato mais vendido por todas as bancas pesquisadas, seguido pela buchada de bode e sarapatel.

Os feirantes incluem pratos no cardápio da banca conforme a demanda dos comensais, porém o cardápio está fixo a muitos anos conforme relatou os feirantes Maria, Tatiana Torres e Claudete Sirino.

Laise Dias, da banca Come Bem, relatou que no final de semana o movimento aumenta muito e para agradar todos os clientes fazem um pouco de cada coisa: mocotó, buchada de bode, sarapatel, galinhada.

Os preços dos pratos variam entre $R \$ 8,00$ a $R \$ 25,00$ e a banca chega a vender mil pratos por final de semana.

Laise relatou ainda que muitos de seus clientes são fiéis e conhece seus gostos, chegando a saber como preferem a montagem de seus pratos: mais molho, mais arroz, menos gordura etc.

O cardápio é similar em todas as bancas de alimentação e algumas barracas utilizam as fachadas das bancas para comunica-lo aos clientes conforme as imagens 31,32 e 33. 


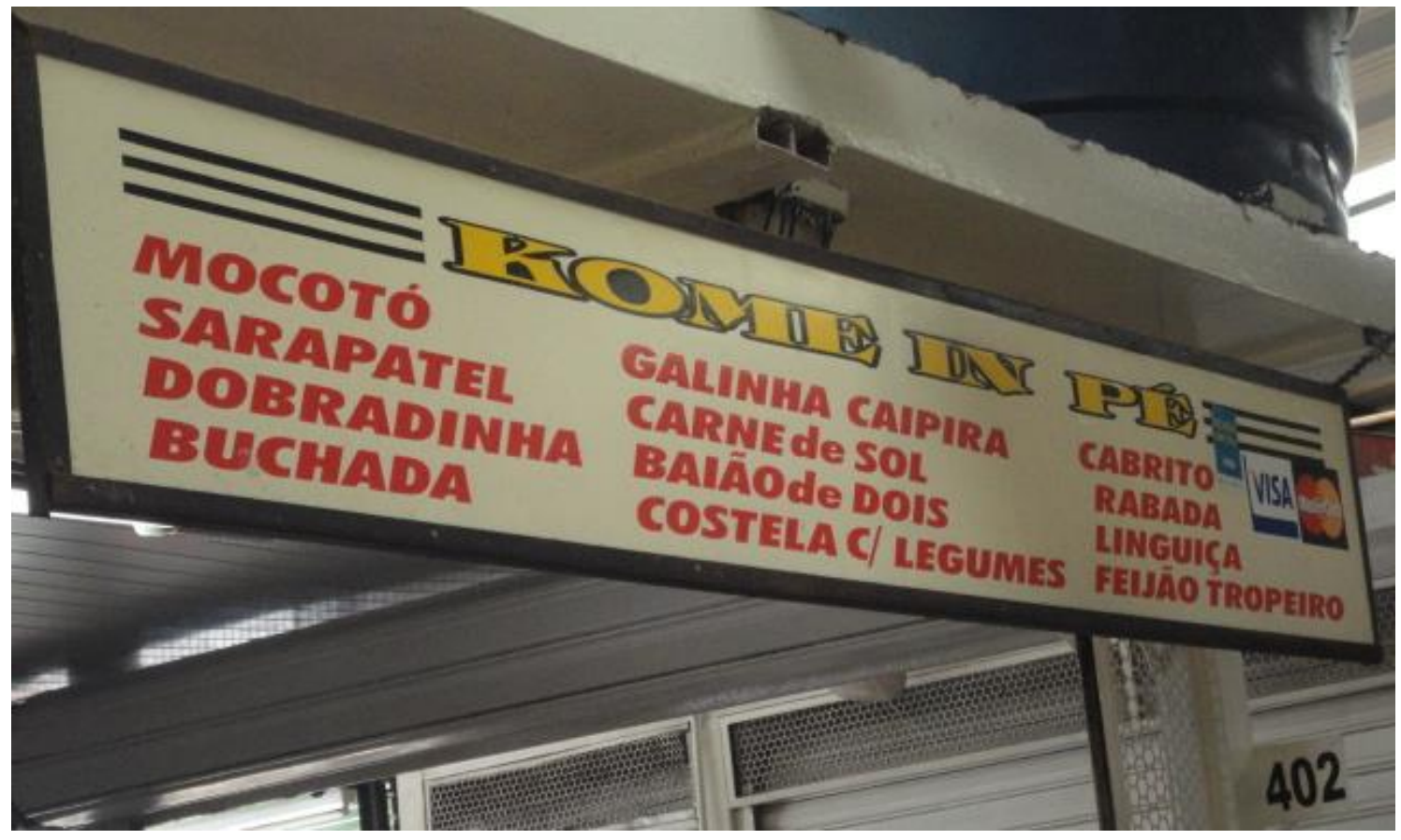

Imagem 31: Cardápio da banca Kome in Pé

Fonte: Imagem registrada pela pesquisadora em 16 de dezembro de 2014.

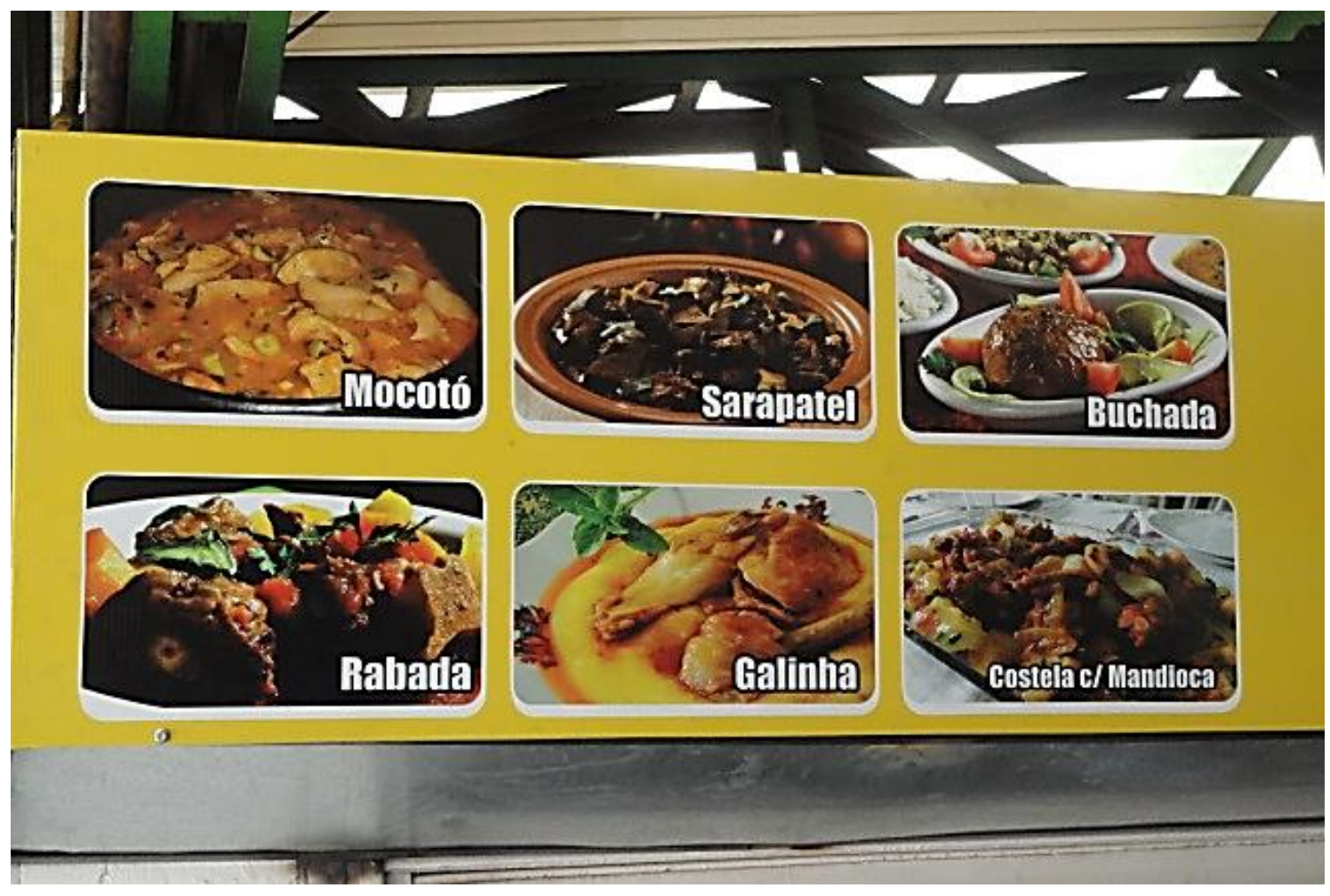

Imagem 32: Fachada Banca da Galega 1

Fonte: Imagem registrada pela pesquisadora em 26 de março de 2015. 


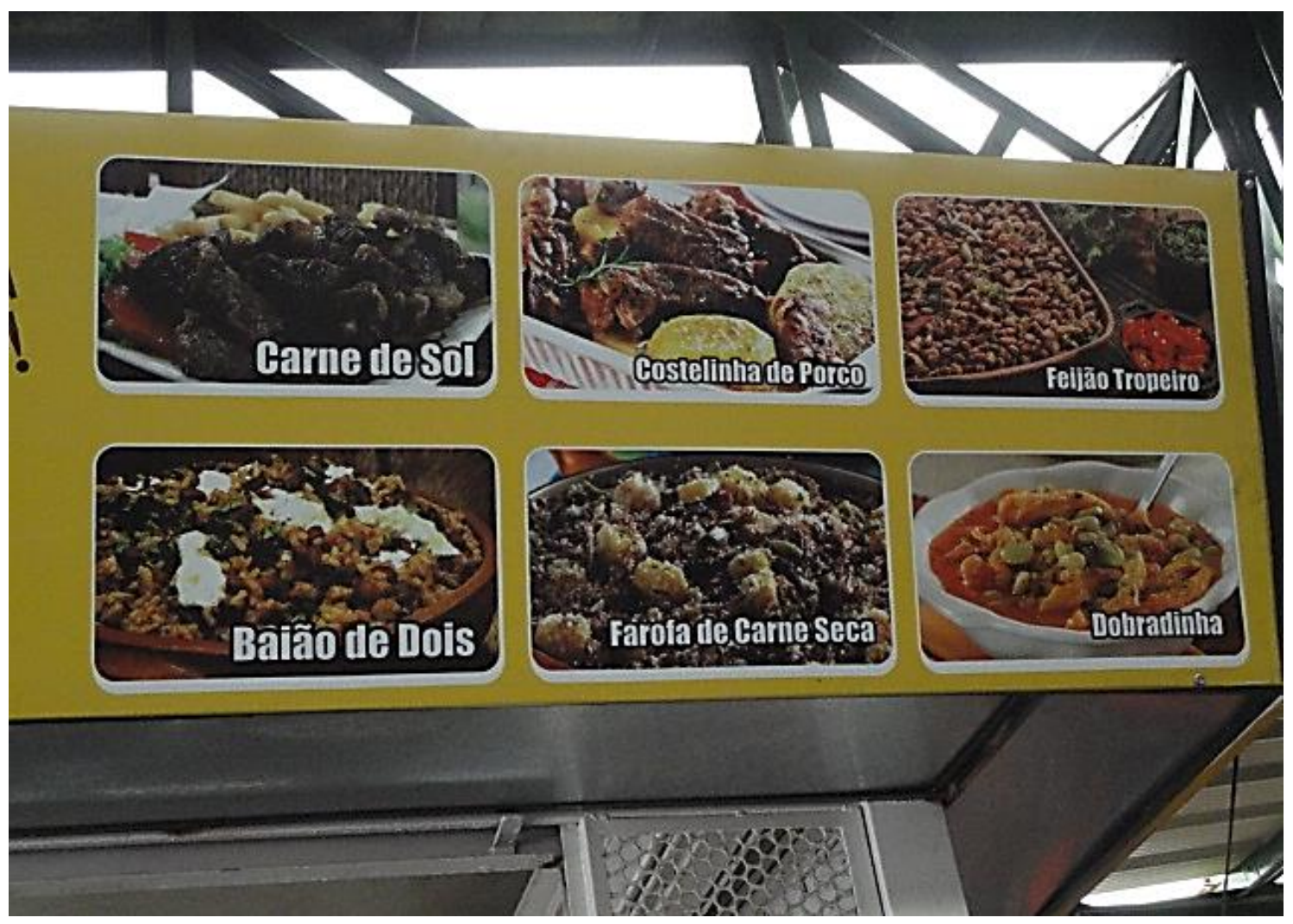

Imagem 33: Fachada Banca da Galega 2

Fonte: Imagem registrada pela pesquisadora em 26 de março de 2015.

Para agradar sua clientela, Maria da Banca do Carlão relatou: "não acrescento cheiro verde nas preparações pois muitos de clientes não gostam, assim, acrescento o tempero apenas na hora de servir se o cliente gostar."

Esse é um padrão também na banca da Tati: Cheiro verde só se o cliente quiser, disse Tatiana.

Galega, como é chamada Edinara dos Santos dona da banca que leva seu apelido Banca da Galega acrescenta pimenta do reino na preparação do Mocotó "porque o povo gosta".

Conforme a Tabela 8 sobre os modos de preparo do Mocotó nas bancas da feira observamos que cada uma das bancas realiza a produção de modo semelhante porém com algumas diferenças. As diferenças incluem a utilização de mandioca para engrossar, pimenta, pimentão, louro, coentro e salsinha. As diferenças pautam-se, conforme relatos, na intenção de agradar seus clientes levando a adaptação da preparação ao paladar dos comensais e, ainda ao fato de que aprenderam a fazer a preparação com pessoas diversas, em tempos diferentes e de variados estados. 
A Edinara da Banca da Galega aprendeu a fazer o mocotó servido em sua banca com sua mãe, natural de Caicó - Rio Grande do Norte.

Francinaldo Sousa, o Naldo como é chamado, da banca Kome in Pé aprendeu a fazer o prato com a mãe que é natural do Piauí. Já Maria da Banca do Carlão aprendeu a fazer com a mãe que é mineira.

Tabela 8: Modo de preparo do Mocotó das bancas da Feira da Ceilândia

\begin{tabular}{|c|c|c|}
\hline Banca & Entrevistado & Modo de preparo \\
\hline Come Bem & Laise Dias & $\begin{array}{l}\text { Pré-cozinhar a pata para retirar a gordura, levar } \\
\text { ao fogo com cebola, pimentão, alho, coloral, } \\
\text { pimenta e açafrão até engrossar. }\end{array}$ \\
\hline $\begin{array}{l}\text { Esquina Sabor do } \\
\text { Nordeste }\end{array}$ & Regina & $\begin{array}{l}\text { Escalda a pata, tempera com cebola, pimentão, } \\
\text { pimenta de cheiro, alho e sal. Cozinha até } \\
\text { engrossar. }\end{array}$ \\
\hline Estação Nordeste & Claudete Sirino & $\begin{array}{l}\text { Cozinhar a pata em água com sal e corante. } \\
\text { Separar o caldo do mocotó. Refogar o mocotó } \\
\text { com cominho, caldo de galinha, corante, cebola } \\
\text { e cheiro verde (coentro e cebolinha) e cozinhar } \\
\text { mais um pouco. Juntar o caldo separado e servir. }\end{array}$ \\
\hline Galega e Buga & Evanir Sntos & $\begin{array}{l}\text { Cozinha a canela por } 45 \text { minutos na panela de } \\
\text { pressão. Separar a canela do líquido. Deixar o } \\
\text { líquido esfriar e retirar toda a gordura da } \\
\text { superfície. Lavar a canela e refogar com cebola, } \\
\text { alho, pimentão, pimenta do reino e corante. } \\
\text { Acrescentar o caldo (sem gordura) e cozinhar até } \\
\text { engrossar. }\end{array}$ \\
\hline Kome in Pé & Francinaldo Sousa & $\begin{array}{l}\text { Cozinhar a pata com água e descartar o líquido. } \\
\text { Refogar a pata com cebola, corante, coentro. } \\
\text { Acrescentar água e caldo de mandioca. Cozinhar } \\
\text { até soltar o colágeno e engrossar o caldo. }\end{array}$ \\
\hline Rei do Mocotó & Patrícia Furtado & $\begin{array}{l}\text { Lavar a pata, cozinhar por uma hora na panela } \\
\text { de pressão, refogar com cebola, alho, pimentão, } \\
\text { corante e louro e cozinhar por muitas horas. }\end{array}$ \\
\hline Banca do Carlão & Maria $^{7}$ & $\begin{array}{l}\text { Escaldar a pata. Descartar o líquido. Refogar } \\
\text { com cebola, alho, corante e sal. Acrescentar } \\
\text { agua para cozinhar até engrossar naturalmente. } \\
\text { Servir com cheiro verde. }\end{array}$ \\
\hline $\begin{array}{l}\text { Banca da Tati (sem } \\
\text { letreiro) }\end{array}$ & Tatiana Torres & $\begin{array}{l}\text { Cozinhar na panela de pressão a pata com alho, } \\
\text { açafrão da terra, e coloral. Escorrer quando } \\
\text { estiver cozido. Em outra panela acrescentar } \\
\text { pimenta, cebola, alho e sal. Ferver bastante. } \\
\text { Servir com cheiro verde (cebolinha e coentro) }\end{array}$ \\
\hline Banca da Galega & Edinara dos Santos & $\begin{array}{l}\text { Escaldar a pata para tirar a gordura. Cozinhar na } \\
\text { panela de pressão com tomate, cebola, } \\
\text { pimentão, coloral, pimenta do reino e cheiro } \\
\text { verde. Engrossar com mandioca. }\end{array}$ \\
\hline
\end{tabular}

Fonte: Elaborado pela pesquisadora (2015).

\footnotetext{
${ }^{7}$ Nome fictício escolhido pela entrevistada que optou por preservar o depoimento no anonimato.
} 
Falas sobre o tato:

O sentido do tato é encontrado não em uma região específica do corpo, mas em toda a pele do corpo humano. A pele, por sua vez, é a interposição entre o mundo interno e o externo. Com o tato podemos sentir o mundo a nossa volta, seja pelo toque ou pela sensação térmica.

Abrigada do sol e da chuva, com iluminação natural e artificial e sensação térmica na feira é agradável tanto em dias de sol quanto de chuva.

Os feirantes fazem questão que o frequentador entre em contato com seus produtos, deixam muitos dos produtos ao alcance de nossas mãos e oferecem degustação de queijos, doces e biscoitos, pegam blusas, vestidos e sapatos e sugerem que sintamos o produto com as mãos, ou com a boca. Porém nem sempre foi assim, muitos feirantes relataram que antigamente (antes de 1984), ficavam no sol e na chuva, com os pés no barro e na lama.

Apertos de mãos e tapinha nas costas são comuns na relação feirante/cliente fiel e feirante/feirante além dos esbarrões nos corredores estreitos. Tratando dos esbarrões nunca os apreendi como um fato negativo, ao contrário. Pedir licença para passar pelos corredores cheios ou esbarrar em alguém tão distraído quanto eu pela quantidade de itens expostos ao alto retirando a preocupação do caminhar era, na forma mais simples, divertido.

Falas sobre o olfato:

Os cheiros na feira são muitos, mas certamente é a proximidade às bancas de temperos, aves, peixes, hortifruti e comidas que os receptores olfativos são mais estimulados.

As peixarias com seu odor característico. As bancas de aves vivas misturam o cheiro de pena molhada, ração e dejetos remetendo ao cheiro de fazenda. Alguns frequentadores não gostam desse odor, como relatado em entrevistas.

Os aromas das bancas de hortifruti variam a cada dia. Basta prestar atenção que os cheiros de cebolinha, coentro, manga, hortelã, morango, melancia se apresentam conforme caminho por entre essas bancas. 
Do corredor das bancas de alimentação vêm os aromas de comida, o qual invade as bancas próximas por volta das 11 horas. É o aviso que a hora do almoço se aproxima.

Falas sobre a memória:

Entre as múltiplas realidades e memórias que a feira da Ceilândia abriga, na qual minha experiência ultrapassa a fala ou a escrita, imprimi especial atenção as que resultam da interação entre os atores da feira.

Não tive a pretensão de verificar a validade de qualquer informação compartilhada comigo por considerar que as formulações da linguagem expressada para comunicar os fatos indagados partem da memória do sujeito entrevistado. Sendo a memória o passado percebido e armazenado que serve de base para guiar o indivíduo no presente, e sendo ainda o sentimento do passado fazendo-se presente (BERGSON, 1999), admito a realidade e as memórias comunicadas como verídicas.

Foram constantes os momentos de descontração durante as entrevistas. Muitos dos frequentadores da feira entrevistados, envolvidos pela atmosfera de intimidade e cumplicidade que este espaço permite, tiveram comigo também uma atitude menos formal, de maior proximidade. Entre uma resposta e outra me deram apelidos, me convidaram para sentar, interessaram-se não apenas por contribuir com minha pesquisa como também por saber de onde eu era, do que eu gostava, o que eu fazia.

Uma senhora certa manhã me disse: "Se você quer saber de mim eu também quero saber de você!".

Por vezes encerrei a pesquisa e continuei a conversar com os entrevistados sobre futebol, música, fotografia, política. Nesse clima e contexto, pude perceber que os frequentadores entrevistados construíram ao longo dos anos um sentimento de identificação com os feirantes de suas bancas preferidas e de pertencimento ao espaço da feira.

Conforme testemunho de Alberto Tavares, natural de Londrina/PR frequenta a feira há 25 anos e vai até lá para observar e se divertir com a interação de feirantes/frequentadores, frequentadores/frequentadores. Relatou que durante as três ou quatro horas que permanece na feira nos finais de semana sempre está convivendo com um ou outro que puxa uma conversa. 
A pessoa pode até estar sentada do outro lado do balcão, isso não é empecilho para um se "meter" na conversa do outro. De fato essa liberdade de entrar na conversa uns dos outros ocorreu durante algumas entrevistas. A intromissão na conversa alheia é recorrente e permitida na feira.

Marcos Alves, brasiliense de 42 anos de idade, filho de piauienses, frequentador da banca na Esquina do Nordeste em entrevista relatou:

"Na feira da Ceilândia tem as comidas que mais amo: galinha caipira, sarapatel e carne de sol com mandioca".

Concluída a entrevista nos despedimos com um aperto de mão e segui em direção a outra banca.

Poucos minutos depois ele grita meu nome e pede para que eu retorne até ele. Lá chegando ele pede para que eu confirme a uma moça que está sentada um pouco mais afastada que ele seria brasiliense. Confirmei mostrando a folha da entrevista. Então ele me explicou que ela, Terezinha, do Piauí, que estava sentada no outro balcão com seu marido, duvidou de sua origem brasiliense quando ele me contou, no início da entrevista, pois achou seu sotaque muito nordestino. Desfeito o mal entendido deixei os dois conversando sobre os sotaques nordestinos. Evidencia que a interação se faz presente, algo inexistente em espaços mesmo contíguos como as praças de alimentação de shoppings.

Na feira um diálogo, mesmo motivado por uma "entrevista para uma pesquisa" torna-se facilmente uma relação dialógica, ou uma conversa intergrupal. Essa construção, o diálogo, na feira vai para além do mero uso da conversa para a venda de produtos. É uma comunicação tátil, demonstrando pessoalidade, que a lógica da feira permite. A atração "feita de entrecruzamentos e de correspondências dos microvalores éticos, religiosos, culturais, sexuais, produtivos, constitui o solo da comunicação, carregando uma correspondência orgânica que liga as pessoas" (MOESCH, 2002, p. 45).

\footnotetext{
Ao participar, no sentido místico do termo comunicação, deste ou daquele evento, cada um se integra a um conjunto que lhe permite, ao mesmo tempo, viver e entrar em correspondência com os outros. Trata-se de uma ordem comunicacional simbólica em seu sentido mais forte, uma ordem que, depois dos parênteses da modernidade, fundada no princípio da individualidade, reencontra o principium relatiouis das sociedades tradicionais ou primitivas. Pode haver nisso uma comunicação que tenha apenas por objetivo tocar o outro. (MOESCH, 2002, p. 45)
} 
A comunicação estrutura a realidade social onde o dado social formará a teia de ligação de uns com os outros.

Ao entrevistar o vascaíno Alan Hudson e sua esposa, que o acompanhava no passeio à feira, esta acrescentou vários detalhes às respostas dele, como de concordância, discordância e complementação.

O mesmo aconteceu ao entrevistar Caio Fernandes. A mãe, os amigos e a feirante Galega foram chamados para ouvir e confirmar seus relatos.

Não foi diferente na entrevista com o atual Governador do Distrito Federal Rodrigo Rollemberg que estava na feira almoçando e concedeu entrevista como "cidadão Rodrigo e não Governador Rollemberg". Em diversos momentos a esposa, Márcia, que o acompanhava, acrescentou e/ou reafirmou a relação dele com as comidas nordestinas. Rodrigo relatou que gosta de buchada, dobradinha e rabada e que comia na casa dos pais no Piauí. Prontamente Marcia disse que nunca viu essas comidas na casa dos pais dele e que ele comia esses pratos sim, mas na casa da mãe dela em Minas Gerais. Os dois se divertiram com isso e ele acabou concordando com ela.

Com essas "intromissões" aceitas e solicitadas na busca das lembranças para responder às questões da entrevista concluo que as recordações assumem maior confiabilidade, para o próprio indivíduo, quando são legitimadas pela memória de outros. Ao recordar junto, os fatos que um e outro se recordam não são os mesmos. Ao lembrar junto com o outro o momento vivido é reconstruído.

As tradições culinárias e certas regras de integração podem ser indicadores empíricos da memória coletiva de um determinado grupo, como uma memória que fundamenta o sentimento de pertencimento (POLLAK, 1989).

Por mais que muitas mercadorias comercializadas na feira da Ceilândia sejam resultantes do processo de homogeneização "impostos" pela globalização, ainda assim a sensação que a feira proporciona é a não pactuação com o ritmo acelerado da metrópole que está ali fora.

Não sinto o vazio (interno) característicos dos espaços públicos de convivência desmaterializada da áurea de historicidade, como nos shoppings. Por mais que as trocas capitalistas ocorram, não sinto estar num "templo de consumo", seja pela teatralidade dos feirantes, espontânea ou forjada, fator que faça com que não me sinta sozinha no meio da multidão. 
Uma feirante me falou em um dos dias que estive na feira: "Confia em mim! Eu sei o que estou falando. Se não for verdade você volta aqui."

\subsection{Para Além do Visível o Papel da Teoria}

O campo simbólico de Bourdieu foi utilizado como base para tratar a cultura gastronômica como expressão pública da existência de várias culturas na cultura brasileira.

Nessa trilha o substrato da teoria de Bourdieu (2011, p. 7) apresenta a necessidade de saber descobrir o que "está em toda parte e em parte alguma" onde o poder simbólico, invisível, ao contrário de ser opressor e coercitivo é propriedade de um grupo e existe apenas quando o grupo o legitima, agindo em conjunto.

Assim, o poder simbólico é gerado apenas na pluralidade das verdades individuais, reconhecidas e reafirmadas, quando o indivíduo se expressa ao grupo e esse concorda, conforme argumentação, nunca pela força física ou econômica. $O$ poder simbólico é uma relação entre o que exerce o poder e os que estão sujeitos a ele. O poder do poder simbólico se concretiza apenas quando não for arbitrário, é uma forma legitimada de poder onde o público delega a autoridade ao particular.

Os sistemas simbólicos são passíveis de análise estrutural. A análise estrutural é um instrumento que possibilita a realização da tradição neo-kantiana (ideia pura das coisas) que trata dos diferentes universos simbólicos, tendo em vista isolar as estruturas profundas de cada produção simbólica.

"Os sistemas simbólicos, como instrumentos de conhecimento e de comunicação, só podem exercer um poder estruturante porque são estruturados" (BOURDIEU, 2011, p. 9). A análise estrutural permite apreender a lógica específica de cada uma das formas simbólicas. É uma abordagem que pretende descobrir a estrutura do fenômeno, penetrar em sua essência para determinar suas ligações determinantes. A estrutura de um fenômeno social diferencia um fato social de outro e dá sentido de permanência, porém se modifica conforme o tempo.

Os sistemas simbólicos são instrumento poderosos da integração social, enquanto instrumentos do conhecimento e da comunicação tornam possível o consenso do sentido do mundo social, legitimando a dominação de uma classe sobre 
a outra (violência simbólica). Seu poder está em construir uma realidade que estabelece uma ordem (BOURDIEU, 2011).

Assim "o campo da produção simbólica é um microcosmo da luta simbólica entre as classes (BOURDIEU, 2011, p. 12), onde o processo de dominação é uma luta pelo "posto" de classe dominante.

\begin{abstract}
A classe dominante é o lugar de uma luta pela hierarquia dos princípios de hierarquização: as frações dominantes, cujo poder assenta no capital econômico, tem em vista impor a legitimidade da sua dominação que por meio da própria produção simbólica, quer por intermédio dos ideólogos conservadores os quais só verdadeiramente servem os interesses dos dominantes por acréscimo, ameaçando sempre desviar em seu proveito o poder de definição do mundo social que detêm por delegação; a fração dominada [...] tende sempre a colocar o capital específico a que ela deve a sua posição, no topo da hierarquia dos princípios da hierarquização. (BOURDIEU, 2011, p. 12)
\end{abstract}

As categorias operatórias, a posteriori, eleitas como instrumento morfológico para construção dos achados dessa pesquisa foram pertencimento, comensalidade, hospitalidade, convivência, identidade coletiva, cultura hibrida, e turismo cidadão.

O conceito de pertencimento é reconstruído nessa pesquisa a partir dos autores Grinover e Augé no qual o sentimento de pertença está pautado no desejo de fazer parte de um grupo, de um lugar, de uma cidade no qual o indivíduo se identifique, se relacione e sinta-se ator das histórias ali ocorridas. O sentimento de pertencimento é imprescindível à hospitalidade.

Para vivenciar e compartilhar a vida ou um alimento a hospitalidade, que é um modo particular de proporcionar ao visitante o sentimento de bem estar, deve se fazer presente. As atitudes e comportamentos de hospitalidade segundo Boff (2005) são: a boa vontade incondicional, acolher generosamente, escutar atentamente, dialogar francamente, negociar honestamente, renunciar desinteressadamente, responsabiliza-se conscientemente, relativizar corajosamente, transfigurar inteligentemente.

Hospitalidade é algo complexo que implica uma percepção de profundidade, que aborda o reconhecimento do outro, ou em termos mais adequados, o acolhimento e a convivência. Nisto observa-se o receber, o ajudar, o abrir-se, o reconhecimento do outro em sua diferença, ou seja, uma visão de hospitalidade mais complexa e aprofundada em laços sociais, ritualísticos e de reciprocidade, constituintes da hospitalidade como valor de troca do sujeito, portanto humanizador. (MOESCH, 2010, p. 9) 
A partir dos autores Boff, Grassi e Moesch reconstrói-se o conceito de hospitalidade. Assim, para esse estudo a hospitalidade não deve ser pensada apenas para o turista, o estrangeiro, o visitante, o viajante, mas sim de uma forma mais ampla, para a cidade, para e pela humanidade nas relações sociais entre diferentes. A hospitalidade então é uma forma, ritualizada ou não, de ligação e de relação de reciprocidade entre os sujeitos buscando igualar o visitante ao visitado. "A hospitalidade supõe a superação dos preconceitos e confiança quase ingênua, mas indispensável para que a hospitalidade e a convivência sejam verdadeiramente hospitalidade e convivência" (BOFF, 2005, p. 95). Hospitalidade é viver a convivência. É relação que se mantem na reciprocidade, que acolhe as diferenças, que se (re)conhece e aprende com o outro.

\begin{abstract}
A hospitalidade é uma virtude. Virtude significa qualidade de moral, a prática do bem. A virtude é valor do sujeito, logo, a hospitalidade enquanto virtude é humana, é subjetiva, é ritualística e é moral. Uma vez que a hospitalidade se define a partir do outro, a convivência com o que é estranho, respeitando o outro em sua diferença é fundamental para a hospitalidade. (MOESCH, 2010, p. 8)
\end{abstract}

Faz-se necessário para a hospitalidade reinventar as relações, os espaços de encontro da casa e da rua. Proporcionar aos sujeitos o sentimento de pertencimento a um lugar, a um grupo, a uma cidade, evitando ao próprio cidadão o sentimento de estar em um não-lugar. A cidade necessita oferecer espaços de contemplação e socialização que convide, primeiramente o morador para posteriormente bem acolher o estrangeiro.

[...] o Planeta Azul mostra sinais de que seu equilíbrio socioecológico precisa ser cuidadosamente preservado, sob pena de todos desaparecerem: pessoas, natureza, planeta. Exigem-se, portanto, novas posturas coletivas e individuais de atenção ao patrimônio comum, tanto o natural como o cultural. No cultural incluem-se as cidades, no seu emaranhado de ruas, pessoas, ideias, comportamentos e problemas. (GASTAL e MOESCH, 2007, p. 9)

Nesse contexto, ainda segundo Gastal e Moesch (2007), o turismo deve ser realizado de maneira responsável e hospitaleira, onde a hospitalidade deve ser exercida não apenas com os que vêm de fora, como também com os vizinhos de rua ou de bairro. E acrescentam que o turismo deve aliar-se à cidadania através de políticas públicas democratizantes a fim de beneficiar as comunidades turísticas e as que a princípio não recebem muitos visitantes. 
Para Gastal e Moesch (2007) a globalização é, além de processos econômicos específicos, os processos culturais desenraizados das tradições locais ligadas ao território levando a homogeneização da sociedade, à padronização do pensamento, das formas de se expressar e agir.

\begin{abstract}
Olhar a cidade com maior cuidado não é mais uma tarefa exclusiva dos turistas que a percorrem. Mesmo para os moradores das cidades, a sua complexidade coloca, cada vez mais, maiores desafios. Decifrá-los é fundamental para sobreviver e viver nas cidades com qualidade. Em especial, nas cidades maiores. (GASTAL e MOESCH, 2007, p. 19)
\end{abstract}

Saber quem se é no tempo e no espaço, ou, seja conhecer e compreender a sua identidade e suas formas de identificação são necessários às cidades e às localidades como forma de integrar as redes globais de forma independente, sem pretender a autonomia, uma vez que se está num processo de ligação em redes. A questão é, não permanecer no processo de globalização de maneira homogênea.

Cada bairro constitui seu espaço identitário.

\begin{abstract}
Se, nas cidades, mesmo os bairros se colocam como espaços de identidade e identificação, para viver outros cenários não seria mais necessário sair dos limites urbanos, pois estes se tornaram o território da multiplicidade, permitindo ao indivíduo ser turista mesmo sem abandonar seu território. Também se estaria migrando de um conceito de turismo marcado pelas distancias espaciais para um conceito que priorizasse a sua prática como o percorrer tempos e espaços diferentes dos rotineiros. Turismo seria menos o percurso no espaço, para tornar-se um percurso por tempos-espaços, em especial culturais, diferentes daqueles a que se esteja habituado, com ênfase nas vivências e experiências. (GASTAL e MOESCH, 2007, p. 37)
\end{abstract}

O turismo envolve o processo de estranhamento que pressupõe deslocamento subjetivo, em tempo e espaço, diferentes do cotidiano. Nesse contexto o estranhamento não tem ligações com a distância percorrida, e sim com a vivencia de uma experiência.

Para haver um turismo des-estereotipado (não de massa), o indivíduo deve estar receptivo ao estranhamento e a diversidade cultural, podendo ser um instrumento na construção da cidadania através das práticas de reconhecimento do seu lugar- a cidade- como construção histórica social o qual faz parte, turista cidadão.

$\mathrm{Na}$ experiência de possibilitar o estranhamento através do distanciamento da cidade como espaço cotidiano para assim alcançar a cidade sob outros olhares o Plano de Ação de 1999 de Porto Alegre propunha que o cidadão turista não apenas 
se apropriaria dos fixos, como também se integraria aos fluxos avançando assim para o conceito de turismo cidadão. Marutschka Moesch gestora da proposta explica o conceito:

\begin{abstract}
Turista cidadão é aquele que resgata a cultura da sua cidade, fazendo uso do estranhamento da mesma. Este estranhamento inicia no momento em que o indivíduo descobre, no espaço cotidiano, outras culturas, outras formas étnicas e outras formas de lazer e entretenimento. Quando se encontra na condição de turista cidadão, este sujeito aprende a utilizar os espaços ambientais, culturais, históricos, comerciais e de entretenimento como uma percepção diferenciada do seu cotidiano. (GASTAL; MOESCH, 2007, p. 65)
\end{abstract}

Para desenvolver o turismo urbano é preciso segundo Gastal e Moesch (2007) construir inicialmente um imaginário positivo da cidade (qualidade de vida dos moradores, limpeza pública, saneamento, acessibilidade, espaços de lazer público entre outros). Porém, acrescentam “o imaginário sobre o local só se sustenta se, além da existência de atrativos naturais e culturais, houver originalidade pela presença do poder local de cidadania, exercitando a sua diferenciação, o seu heterógeno, a sua cultura tradicional" (GASTAL e MOESCH, 2007, p. 56).

Para atrair o turista é preciso primeiro atrair a própria população. Colocar as pessoas que fazem parte dos fluxos da cidade em movimento, deslocando-se da sua rotina, transformando-as em visitantes de sua própria cidade.

Turismo cidadão é para além da atividade turística uma expressão cidadã, uma forma de conhecer e compreender a cidade:

Para o cidadão turista, os fixos que compõe a cidade deixam de ser desconhecidos. O território torna-se familiar e, nele e com ele, constrói relação de pertencimento e identidade, pois se passa a compartilhar seus códigos e, de posse dos mesmos, a situar a própria subjetividade em relação aos fixos presentes no urbano. (GASTAL e MOESCH, 2007, p. 60)

Assim, a partir das autoras Gastal e Moesch ressignifica-se turismo cidadão como fenômeno onde o habitante sensibilizado desenvolve um relacionamento diferente com o local onde mora no seu tempo de lazer, que exposto ao estranhamento, utilizando-se dos fixos e fluxos da cidade com percepções diferentes da cotidiana e apropriando-se da cidade por meio da experiência vivida.

Para ressignificar comensalidade foram utilizados os autores Boff, Boutaud, Grassi e Montanari. Boutaud e Boff afirmam que o ritual de hospitalidade culmina no comer juntos. Grassi acrescenta que dividir a mesa é vivenciar a hospitalidade através 
da igualdade de visitante e visitado onde aceitar o estrangeiro à mesa é a comprovação da aceitação e do desejo de compartilhar o que se tem e de abrir-se mostrando quem realmente se é. Montanari ressalta que o primeiro indício de pertencimento a um grupo é a participação da mesa comum.

Comer junto assume, então, um significado ritual e simbólico superior à simples satisfação de uma necessidade alimentar. Essa forma de partilha, de troca, de reconhecimento é chamada comensalidade. (BOUTAUD, 2011, p. 1213)

Boutaud (2011) completa que o comensal assume primeiramente a figura de hóspede e é identificado como convidado ou conviva, pois a comensalidade agrupa rituais de hospitalidade e os da mesa. Há o vínculo entre comensalidade e conviviabilidade.

\begin{abstract}
No contexto ordinário, não se trata só de comer, mas de saber comer em comum, de ser visto comendo, sob o olhar dos outros. Todo o ambiente se torna um cenário, a encenação da refeição, a encenação de si. O que é necessário, comodidade ou habito assume um caráter de símbolo ou força de ritual. Isso significa colocar em jogo seu comportamento, sua imagem, sua identidade, criada dessa forma na relação com o outro e favorecida pela mesa ou pelo local ritual da refeição. Numerosas atividades e resultados conjugados, inevitavelmente associados a um cortejo de normas, de regras e de proibições, de prescrições, devedoras das maneiras à mesa, mas também de tolerância, liberdades, transgressões, que encorajam todas as ocasiões para comer e, mais ainda, para beber. (BOUTAUD, 2011, p. 1213)
\end{abstract}

Ainda conforme Boutaud (2011) o ritual da refeição é cartografado em dois eixos, o horizontal representando a agregação e a coesão da comensalidade (formação da comunidade, encontro, vínculo, intercambio, abertura, relaxamento, diversão) e o vertical que propõe o respeito as normas, hierarquia e lugares e a procura de novas e agradáveis sensações. Na dimensão simbólica a comensalidade deve ser conceituada por seus eixos horizontais e verticais e ainda pelo caráter unificante e transcendente (BOUTAUD, 2011).

A reflexão da função social e simbólica da alimentação e a necessidade de convivência foi feita por Boutaud (2011) analisando o comportamento animal que divide e comunga o alimento e pela utilização do fogo coletivo na era neolítica para preparar os alimentos e dividi-los em seguida. "Muito rapidamente é estabelecida a ligação entre as regras de partilha alimentar, a estruturação dos grupos e sua 
afirmação identitária" (BOUTAUD, 2011, p. 1214). Assim, esses primeiros sinais de humanização conduzem ao comer simbólico, origem da comensalidade.

O comer simbólico pode ser compreendido, desde então, em dois níveis. Um primeiro nível é o da incorporação, que dizer, da ingestão de valores ligados aos alimentos; um segundo nível é ligado ao valor simbólico dos alimentos tomados em comum e o vínculo simbólico da refeição em grupo. A comensalidade opera nos dois níveis, porque a natureza dos alimentos age diretamente sobre a natureza dos convivas. Pelo menos se pensa que ela atua assim. Isso condiciona, desde sempre, a escolha das carnes, dos legumes ou das poções e das bebidas. (BOUTAUD, 2011, p. 1214)

A relação à mesa não apenas cria laços como fortalece os existentes e também separa e provoca afastamentos identitários.

Função mágica desde a origem, rituais profanos e sagrados, prescrições e proibições religiosas, os estímulos identitário do cenário alimentar não faltam. Assim, adivinhamos que, se os alimentos têm sua importância, se considerarmos o que comemos, comer conjuntamente é ainda mais considerado. A prática da convivência no seu sentido próprio, a própria imagem da vida em comum (cum vivere), fortalece, desde sempre, a ideia de que comer e beber com o outro favorece a empatia, a compreensão mútua, a comunhão dos sentidos. (BOUTAUD, 2011, p. 1215)

Na comensalidade, o sentar-se à mesa para a refeição não significa apenas o momento de comer e beber, mas o de viver e partilhar essa experiência com códigos e regras estabelecidos.

Nesse contexto a ressignificação de comensalidade para esse estudo é então, comer e beber junto, construindo e afirmando uma identidade coletiva promovendo laços sociais e partilhando uma maneira de viver.

Com os autores Boff e Boutaud convivência é ressignificada como a forma globalizada e inclusiva de vivenciar a experiência humana. Partilhar a vida e coexistir junto com o outro, "trata-se de uma vivencia vivida sempre com os outros (con) e jamais sem os outros" (BOFF, 2006, p.32).

A categoria de identidade ressignificada, a partir de Hall (2011) cujo conceito de identidade é complexo e a identidade moderna está sendo descentrada, fragmentada. Mudanças estruturais estão transformando as sociedades modernas ao ponto de fragmentar bases tidas como sólidas e mudando a identidade pessoal, abalando a ideia de indivíduos integrados. 
A "descentrarão dos indivíduos tanto de seu lugar no mundo social e cultural quanto de si mesmos constitui uma crise de identidade para o indivíduo" (HALL, 2011, p. 9).

Hall (2011) trabalha com três concepções de identidade, a do sujeito do Iluminismo, individualista, cujo centro essencial do eu era a identidade de uma pessoa; a do sujeito sociológico, interativo, no qual o núcleo interior é formado pela interação com o meio em que ele ou ela vive, preenchendo o espaço entre o interior e o exterior, entre o mundo pessoal e o mundo público.

A identidade, então, costura o sujeito à estrutura. Estabiliza tanto os sujeitos quanto os mundos culturais que eles habitam, tornando ambos reciprocamente mais unificados e predizíveis. (HALL, 2011, p. 12)

A última concepção de que trata Hall é a do sujeito pós moderno composto por várias identidades, não fixas, impermanentes, formadas e transformadas continuamente.

\begin{abstract}
O sujeito assume identidades diferentes em diferentes momentos, identidades que não são unificadas ao redor de um eu coerente. Dentro de nós há identidades contraditórias, empurrando em diferentes direções, de tal modo que nossas identificações estão sendo continuamente deslocadas. Se sentimos que temos uma identidade unificada desde o nascimento até a morte é apenas porque construímos uma cômoda história sobre nós mesmos ou uma confortadora narrativa do eu. (HALL, 2011, p.13)
\end{abstract}

A globalização impactou as identidades culturais pois as práticas sociais são constantemente examinadas e reformuladas à luz das novas, transitórias e rápidas informações percebidas.

A identidade é uma construção da imaginação. A consciência da natureza complexa e construída da identidade possibilita o reconhecimento de que a própria história está contida em outras histórias. Possibilita ainda compreender que o homem moderno não está completo, mas em constante movimento que o leva a encontrar o desconhecido, o estrangeiro, dentro dele mesmo.

Nesse contexto, segundo Chambers (1995) a identidade é formada onde se cruzam as histórias subjetivas individuais com as narrativas de uma história, de uma cultura. Ela não é fixa. 
En ese passaje, y a través del sentido de lugar y pertencia que ali construimos, nuestras historias individuales, nuestros impulsos y deseos inconscientes assumem siempre uma forma contingente, em tránsito, que no tiene ni meta ni final. (CHAMBERS, 1995, p.46)

Segundo Hall (2011) as sociedades da modernidade tardia são caracterizadas pelas diferentes e variadas identidades que o indivíduo assume. E completa que as sociedades não se desintegram porque as diferentes identidades podem se articular conjuntamente. Assim a identidade permanece aberta possibilitando o surgimento de novas identidades que se formam a partir dos pontos nodais particulares de articulação.

O sujeito da modernidade é então, sujeito e sujeitado. Causa e consequência.

O sujeito é submetido a diferentes situações sociais onde os diferentes papeis sociais são negociados.

O sentimento de pertença a um local geográfico é uma memória significativa porém imaginar possuir uma identidade acabada e plena é não abrir-se ao diferente. $\mathrm{O}$ eu, que se conhece e se reconhece, que mantem a integridade do indivíduo, é como qualquer outra realidade fabricada. A realidade e a fantasia se confundem. Não há uma realidade pura que leve automaticamente a uma identidade compartilhada porém os contatos das partes anteriormente separadas proporcionam o meio para reconhecerem-se e identificarem-se.

\footnotetext{
Assim, a identidade é realmente algo formado, ao longo do tempo, através de processos inconscientes, e não algo inato, existente na consciência no momento do nascimento. Existe sempre algo "imaginário" ou fantasiado sobre sua unidade. Ela permanece sempre incompleta, está sempre "em processo", sempre "sendo formada". (HALL, 2011, p. 39)
}

Nesse contexto dever-se-ia falar em identificação, e não em identidade acabada.

\begin{abstract}
A identidade surge não tanto da plenitude da identidade que já está dentro de nós como indivíduo, mas de uma falta de inteireza que é "preenchida" a partir de nosso exterior, pelas formas através das quais nós imaginamos ser vistos pelos outros. (HALL, 2011, p. 39)
\end{abstract}

A tentativa de buscar a identidade é a procura pela fantasia de se sentir acabado, completo. 
Nesse contexto a identidade do sujeito pós moderno é aberta, contraditória, inacabada e fragmentada.

As consequências da globalização sobre as identidades são segundo Hall (2011) as identidades nacionais estão se desintegrando por causa da homogeneização cultural e do pós-moderno global; as identidades nacionais e as locais estão sendo reforçadas; as identidades nacionais estão em declínio dando espaço a identidades híbridas.

Conforme Chambers (1995) não há explicação encerrada para o compartilhamento mutável, o movimento e a multiplicidade anulam qualquer lógica que tentam reduzir o todo ao mesmo, o discurso da história ao conhecimento. O que implica entrar num estado de hibridação onde nenhuma narrativa determinada pode assumir a representação da verdade completa.

Assim, esse estudo ressignifica identidade coletiva utilizando os autores Stuart Hall e lain Chambers como aberta, contraditória, inacabada, múltipla e interativa onde o interior é formado pela interação com a sociedade completando e complementando o mundo pessoal e o mundo público.

Para esse estudo reconstruiu-se o conceito de cultura híbrida utilizado o autor Nestor Canclini e Stuart Hall a fim de que a cultura não seja tratada como estática nem entendida como pura e autentica. Assim cultura híbrida é ressignificada como um processo sociocultural onde há uma mistura de estruturas que combinadas formam uma nova estrutura onde o hibridismo não é tratado como um termo migratório da biologia para as ciências sociais mas como um termo que represente o momento desafiador que a humanidade está tentando viver.

O local versus o global tem imprimido transformações nas identidades e possibilitado a ressignificação da identidade coletiva. Para ressignificar, bem como para investigar os modos de saber/fazer na Feira da Ceilândia faz-se necessário incluir o entendimento que o global e o local coabitam o mesmo espaço onde desvelase um processo de hibridização cultural o que estudaremos no terceiro capítulo desta dissertação. 


\section{FEIRA PERMANENTE DA CEILÂNDIA COMO ESPAÇO DE HIBRIDIZAÇÃO CULTURAL}

Construir lugares depende das ligações, indissociáveis, entre espaço e o processo de construção da identidade (SILVANO, 2010). Nesse contexto o lugar é a forma significativa que o homem tem de se mostrar presente, vivo. "Observar o espaço significa observar as práticas sociais que o constituem" (SILVANO, 2010, p. 46).

A identificação da feira como espaço nordestino é uma referência para a região da Ceilândia que deu sustentação à vida dessa comunidade. Hoje tenta-se reproduzir a alimentação tradicional do Nordeste enquanto os demais itens comercializados na feira, com exceção das bancas de utensílios, temperos e aves vivas, cederam à pressão da globalização e passaram a comercializar roupas e sapatos homogêneos. Por toda a feira se vê cópias e réplicas de roupas e sapatos de marcas internacionais: GAP, Adidas, Nike, Dudalina, Lacoste, entre outras. As barracas de queijos e doces de origem mineira também estão presentes na feira.

Com alguma resistência a feira busca preservar sua identidade, porém o aproximar das distancias e as tecnologias alteraram ou substituíram as práticas tradicionais por processos de globalização.

As tendências do mundo pós-moderno são a homogeneização global, a fascinação com a diferença e a mercantilização étnica e da alteralidade.

Há juntamente com o impacto do global, um novo interesse pelo local. A globalização [...] na verdade, explora a diferença local. Assim ao invés de pensar no global como "substituindo" o local seria mais acurado pensar numa nova articulação entre "o global" e "o local. (HALL, 2011, P. 77)

A globalização não pretende destruir as identidades nacionais, mas sim produzir novas identificações globais e locais, pois a medida que a globalização aproxima os distantes possibilita o encontro entre o "centro" e a "periferia" do sistema global. Acreditar que os grupos periféricos são puros, tradicionais e intocados é uma fantasia ocidental sobre a alteralidade. A globalização se estende a todos, porém na periferia as contradições são mais agudas.

O fortalecimento das identidades locais pode ser uma resposta defensiva à exclusão e segundo Hall (2011) uma estratégia que inclui a reidentificação com a 
cultura de origem, a construção de contraetnias ou o revival do tradicionalismo cultural.

Nesse contexto Hall (2011) conclui que a globalização tende a deslocar as identidades centradas e fechadas, onde algumas gravitam em torno da tradição e outras em torno da tradução. A tradição tenta recuperar a pureza que se pensa perdida. A tradução aceita as ocorrências históricas e não pretende ser autentica.

\begin{abstract}
Este conceito (da tradução) descreve aquelas formações de identidade que atravessam e intersectam as fronteiras naturais, compostas por pessoas que foram dispersadas para sempre de sua terra natal. Essas pessoas retêm fortes vínculos com seus lugares de origem e suas tradições, mas sem a ilusão de um retorno ao passado. Elas são obrigadas a negociar com as novas culturas em que vivem, sem simplesmente serem assimiladas por elas e sem perder completamente suas identidades. Elas carregam os traços das culturas, das tradições, das linguagens e das histórias particulares pelas quais foram marcadas. A diferença é que elas não são e nunca serão unificadas no velho sentido, porque elas são, irrevogavelmente, o produto de várias histórias e culturas interconectadas, pertencem a uma e, ao mesmo tempo, a várias "casas" (e não a uma "casa" particular). As pessoas pertencentes a essas culturas híbridas têm sido obrigadas a renunciar ao sonho ou à ambição de redescobrir qualquer tipo de pureza cultural "perdida" ou de absolutismo étnico. Elas estão irrevogavelmente traduzidas. (HALL, 2011, p. 89)
\end{abstract}

A globalização se realiza no cotidiano como expressão do mundial redefinindo seu conteúdo, sem anular as particularidades. A mundialização traz a tendência à homogeneização, porém, permite, segundo Carlos (2007) a diferenciação.

O lugar se produz na articulação contraditória entre o mundial que se anuncia e a especificidade histórica do particular. Deste modo o lugar se apresentaria como ponto de articulação entre a mundialidade em constituição e o local enquanto especificidade concreta, enquanto momento. (CARLOS, 2007, p.14)

O mundo foi encolhido. O local está ligado ao global pela interdependência do primeiro com o segundo. A globalização se realiza nas contradições do local e do mundial. A tendência da globalização é a desterritorialização e o desenraizamento provocando uma mudança de significações no espaço. O espaço se reconfigura criando uma espacialidade própria onde ocorre a justaposição do local, nacional e regional com o pano de fundo mundial. As referências são universais, mas a vida ganha sentido no cotidiano. 
Apesar de influenciada pelo global, é no local que a história tem sentido, nas configurações das práticas da feira Permanente da Ceilândia. O tempo está sendo eliminado, não o espaço.

\subsection{Socialização: Hospitalidade, Convivência e Comensalidade}

A vida cotidiana está empobrecida. Os indivíduos estão sendo consumidos pela quantidade e volatilidade das informações. A tecnologia dos transportes que inicialmente sugeria o aproximar das distancias transforma-se em martírio diário ao fazer com que os trabalhadores passem horas por semana dentro de veículos próprios ou públicos. É preciso trabalhar mais para ganhar mais. Alimenta-se o corpo com insumos industrializados preparados e consumidos no menor tempo possível. Sentese o faltar de horas no final do dia, da semana. As crianças são monitoradas por equipamentos eletrônicos. Os pares comunicam-se por outros dispositivos eletrônicos; frios, distantes, impessoais. As pessoas levantam muros e impõe barreiras, fechando-se em casa, no trabalho e no caminho de casa para o trabalho a fim de se protegerem da violência característica das cidades com diferenças sociais. O dia a dia está enfraquecendo as relações simbólicas, a convivência e a socialização. Utilizando-se do conceito criado por Georg Simmel (1858-1918), Frugólio Junior (2007) apresenta a sociabilidade como o

Social puro, forma lúdica arquetípica de toda a socialização humana, sem quaisquer propósitos, interesses ou objetivos que a interação em si mesma, vivida em espécie de jogos, nas quais uma das regras implícitas seria atuar como se todos fossem iguais. (FRUGÓLIO JUNIOR, 2007, p.9)

O mesmo autor acrescenta que a sociabilidade deve ter compartilhamento de capital cultural, onde sociedade resulta de interações recíprocas, continuas e solúveis, entre indivíduos que formam uma rede, uma associação, uma unidade. ${ }^{8}$

A Escola de Chicago primeira a voltar-se ao contexto social, re-significa sociabilidade ao conceitua-la como: "os modos, padrões e formas de relacionamento

\footnotetext{
${ }^{8}$ Entendido como "construção da individualidade, inserida em totalidade mais amplas de parentesco, religiosidade e moralidade, com ênfase, portanto, no campo das relações a partir das quais as pessoas se inscreveriam numa totalidade social hierarquizada" (FRUGOLIO JUNIOR, 2007, p. 53),
} 
social concreto em seus contextos ou círculos de interação e convívio social." (FRUGÓLIO JUNIOR, 2007, p. 17), onde a cidade pode ser pensada nos espaços em que tais relações ocorressem. Assim Simmel estabeleceu a convivência, a interação, a socialização e a associação como as conexões entre sociabilidade e a cidade moderna.

A consequência da urbanização na vida das cidades é, segundo Oliven (2007), responsável pelo afrouxamento dos laços sociais. Contudo, a reciprocidade, as relações de parentesco, de familiaridade e de conterraneidade são utilizadas como meios para garantir a sobrevivência, uma vez que isoladamente o indivíduo não conseguiria permanecer imune à cidade.

Ambos, Krippendorf (2003) e Marcellino (2002), comungam da ideia que é necessário estabelecer condições de vida mais humanas, mais harmonizadas onde os valores estejam pautados na vivência e não no desenvolvimento econômico. Permanecer considerando aceitável um dia a dia estressante e empobrecido de vida em prol de maiores rendimentos econômicos que possibilitarão maior consumismo e melhores momentos de lazer, ou seja de convivência ${ }^{9}$, é, na melhor forma, leviano. $O$ próprio planeta Terra não suportará.

\footnotetext{
Vivencia deriva de conviver e de coexistir. Con-viver e co-existir são modos de ser globalizantes e inclusivos. É consequência da vida, tomada em sua plena complexidade, partilhada junto com os outros, coexistindo com eles e participando dinamicamente de suas vidas, de seu sentido de ser, de suas lutas, de suas buscas, de suas derrotas e de suas vitórias. (BOFF, 2006, p.33)
}

A problemática se acentua ao nos depararmos ainda segundo Krippendorf (2003) com a bipolarização do homem: trabalhar aqui - morar ali - repousar em outro lugar. Tudo isso porque as cidades estão cada vez mais interessadas em concentrar na porção central unidades produtoras e menos preocupadas com as necessidades dos que por ali vivem. Assim, a interação social não é pensada pela e para a sociedade.

Mudar o paradigma civilizatório, perceber a realidade a partir de outros pontos de vista e, simultaneamente, de todos os pontos com a visão voltada para o futuro são, segundo Boff (2005), essenciais não apenas para a boa convivência entre os

\footnotetext{
9 "Como a filologia da palavra convivência claramente sugere, trata-se de uma vivencia vivida sempre com os outros (con) e jamais sem os outros". (BOFF, 2006, p.32)
} 
povos nesse momento globalizado, como também para a continuidade da espécie humana.

Todos os seres se entrelaçam em redes de inter-retro-conexões no interior dessa totalidade complexa, cósmica, terrenal, biológica, antropológica e espiritual. Nem a Terra nem o ser humano estão prontos. Continuam evoluindo, se expandindo e nascendo em processo de gênese continuada. (BOFF, 2005, p. 28)

Humanizar o humano desafiando-o a viver a partir de sua singularidade é entender que o planeta é uma fonte esgotável de recursos. Que nele coabitam milhares de pessoas com características, ideologias, crenças e costumes diferentes onde urge a necessidade de se encontrar uma maneira de respeitar e relativizar tais diferenças para que se possa conviver como uma única sociedade, a sociedade planetária. Não se trata de homogeneizar pensamentos e crenças, trata-se de aceitalas em prol da sobrevivência humana.

Considerar a conexão da humanidade pela globalização é, segundo Boff (2005) um salto para um avanço da humanidade uma vez que não tem-se mais povos isolados e todos podem trabalhar rumo a uma mesma direção. Essa direção deve estar pautada no cuidado com o planeta e na aceitação da existência das diferenças. Para o novo paradigma da globalização se efetivar Boff (2005) apresenta a Hospitalidade, a Convivência e a Comensalidade como "energias propulsoras". Essas energias devem abastecer a tecnologia, a política e o social para efetivamente mudar o rumo da humanidade e impedir maus piores.

A hospitalidade se apresenta como uma ponte frágil e perigosa estabelecida entre dois mundos: o exterior e o interior, o de dentro e o de fora. (GRASSI, 2011, p. 45)

O conceito de hospitalidade é uma construção onde tenta-se igualar o hóspede, que chega, ao hospedeiro, dono do espaço urbano ou doméstico (GRASSI, 2011). Há a presença da relação de poder onde o "dono" autoriza a entrada e permanência do estrangeiro. Para dividir o espaço que é tido como de sua propriedade o indivíduo primeiro deve sentir-se pertencente e responsável por aquele local. Quando se trata da casa, esse sentimento é facilmente percebido e sentido, porém quando relacionam-se a áreas públicas o sentimento de propriedade e pertença é, em muitos casos, enfraquecido. 
Em casa está presente o sentimento de igualdade, pertencimento, de inclusão, de agente ativo, de indivíduo apoderado de suas obrigações e deveres. Local ainda, acrescenta Castan (2009, p. 402) "de eleição de amizades e das liberdades". Na rua ocorre o oposto. A urbanização forma estruturas instáveis onde prejudica os encontros de indivíduos politizados. A exclusão e a democracia não praticada faz o indivíduo acreditar que a rua é problema do Estado. Assim a vida privada é valorizada, mesmo sendo constantemente ameaçada pela disciplina e rigor da vida pública.

Ao flâneur das cidades, de Gros (2010), caminhar pelas novas megalópoles, com todo o seu sentimento de resistência a urgência do mundo atual, vê o que a própria cidade anula. Constata ao caminhar, no seu tempo e ritmo, que a cidade possui cada vez menos espaços com cada vez mais e maiores diferenças entre os bairros. "Tudo pode mudar de um distrito ao outro: a dimensão das casas, a arquitetura geral, o ambiente, o ar que se respira, o modo de vida, a luz, as categorias sociais" (GROS, 2010, p. 178). O que faz de cada espaço um espaço diferente do outro são as relações que se dão nesse e com esse lugar. As delimitações espaciais, com destinações impostas não são suficientes para significar o lugar. A organização dos espaços e constituição dos lugares são motivações e modalidades das práticas coletivas.

Para Grinover (2007) o sentimento de pertencimento é imprescindível ao se tratar de hospitalidade onde o desejo de pertencer a um grupo, a uma cidade ou a um espaço vem motivando movimentos sociais e práticas culturais.

O que torna a cidade bonita e hospitaleira é sua capacidade de expressar um
microcosmo social e arquitetônico ordenado, no qual cada edifício, por suas
qualidades, mostra não só sua própria importância, mas também a
importância de quem o encomendou e que ali vive. (GRINOVER, 2007, p. 86)

DaMatta (1997) acrescenta que o que transforma o estranho em visitante é a forma, ritualizada e solene, com que se dá a transposição da soleira que separa a casa da rua. Grassi (2011) acrescenta que adentrar a soleira e conquistar a mesa é vivenciar a hospitalidade através da igualdade das categorias de poder onde "dono" e "visita" estão sob o mesmo teto e podem sentar-se à mesa para compartilham o alimento e a bebida. 
$\mathrm{Na}$ visão de Sergio Buarque de Holanda o brasileiro agrega à sua hospitalidade, a generosidade e a afabilidade no trato. Por vezes aceita a formalidade, mas desde que esta não descarte a possibilidade de um contato mais íntimo. Utilização de diminutivos e uso apenas do prenome são alguns exemplos das formas como o brasileiro propõe o estabelecimento de maior intimidade (PIRES, 2001).

Acolher o estrangeiro, em casa ou na rua, é ter consciência e respeito pelas diferenças, relativizando-as. Porém antes de traçar um canal de ligação e reciprocidade com o outro é preciso saber quem se é e qual lugar se ocupa. E ainda, é, segundo Grassi (2011) um gesto condicional e incondicional, profano e sagrado pois o estrangeiro está à mercê da sorte mas também pode ser ele próprio qualquer sorte.

Para praticar a hospitalidade é preciso abrir-se e abandonar os preconceitos e medos do desconhecido acolhendo o visitante nas esferas materiais e espirituais (abrigo, comida, bebida, cooperação, solidariedade, afetividade). "A hospitalidade supõe a superação dos preconceitos e confiança quase ingênua mas indispensável para que a hospitalidade e a convivência sejam verdadeiramente hospitalidade e convivência" (BOFF, 2005, p. 95).

A casa, portanto, é um lugar especial que abriga iguais e é marcada pela familiaridade e hospitalidade. Local harmonioso no qual as disputas são evitadas, onde "...todos que habitam uma casa brasileira se relacionam entre si por meio de laços de sangue, idade, sexo e vínculos de hospitalidade e simpatia que permitem fazer da casa uma metáfora da própria sociedade brasileira" (DAMATTA, 1997, p. 49).

Aymard (2009) acrescenta que a esfera familiar "[...] não esgota a esfera do privado, nem a da afetividade, nem mesmo a da formação da personalidade" (AYMARD, 2009, p. 440). Com a alteração do contexto familiar e, em alguns casos, da inexistência dela os indivíduos podem formar a partir de outras naturezas, que não a consanguínea ou a de parentesco, esferas de familiaridade.

Na casa, seja ela de dominantes ou dominados, a sociedade se reinventa. Já a rua, de características opostas à casa, pode também abrigar espaços marcados por reproduções de grupos que desenvolvem o sentimento de pertença a tal ponto que esse espaço se torne casa.

Para esclarecer a ideia de público Toro (2005) o conceitua não como o que é gratuito ou de propriedade do Estado, mas como o que satisfaz e possibilita uma vida digna a todos. Considera que essa construção é realizada pelas elites dirigentes 
formadas por intelectuais, comunicadores, políticos, artistas, administradores, diretores e líderes de organizações da sociedade civil, empresários, líderes sociais, comunitários e religiosos. O público pressupõe o atendimento das necessidades dos indivíduos de forma igualitária, onde as diferenças devem ser tratadas em suas especificidades.

O não lugar é promotor da individualidade solitária, é passagem, provisoriedade, efêmero. "Se um lugar pode se definir como identitário, relacional e histórico, um espaço que não pode se definir nem como identitário, nem como relacional, nem como histórico definirá um não lugar” (AUGÉ, 2012, p. 73).

O paradoxo do momento, segundo Augé (2012) é refletir sobre o lugar que se ocupa no espaço onde quanto maior a ligação mundial em redes maior é a necessidade de "particularismo", de reencontrar uma pátria.

\footnotetext{
O personagem está em casa quando fica à vontade na retórica das pessoas com as quais compartilha a vida. O sinal de que está em casa é que se consegue se fazer entender sem muito problema, e ao mesmo tempo se consegue entrar na razão de seus interlocutores, sem precisar de longas explicações. (AUGÉ, 2012, p. 99)
}

A casa é aquilo que acolhe o ser. Segundo Bachelard (1998) pode-se entende-la como a própria imaginação, como o indivíduo como a morada do ser ou ainda como aquilo que acolhe o ser, o "não-eu que protege o eu" (BACHELARD, 1998, p. 24). Por isso quando a casa é chamada à lembrança, é revivida com características e filtros subjetivos, como a defesa do esquecimento ou a fantasia do momento vivido. Por se tratar de uma (re)descoberta do eu, com toda a carga familiar, social e cultural que o indivíduo agrega em seu livro "virtual", a mente, ela é desenhada por ela própria, em constante conflito personagem/autor. Vale ressaltar que, ainda segundo Bachelard (1998), o ser nunca se esquece da ligação que possui com a casa.

\footnotetext{
A casa define tanto um espaço íntimo e privativo de uma pessoa (por exemplo: seu quarto de dormir) quanto um espaço máximo e absolutamente público, como ocorre quando nos referimos ao Brasil como a nossa casa. (DAMATTA, 1997, p.15)
}

Ao utilizar a casa e a rua como categorias sociológicas, no sentido de Durkheim e Mauss, DaMatta (1997) busca compreender a sociedade brasileira de maneira globalizada. Casa e rua não são tratados como espaços geográficos, mas sim como esferas de ação social, com moral, ética, cultura, ideal, emoção, imagem e 
imaginário. Os espaços não são criados com simples demarcações territoriais, são construções legitimadas pelos que ali vivem e convivem.

[...] categorias sociológicas no sentido preciso de Durkheim e Mauss, como um conceito que pretende dar conta daquilo que uma sociedade pensa, e assim institui como seu código de valores e ideias: sua cosmologia e seu sistema classificatório; e também para traduzir aquilo que a sociedade vive e faz concretamente - o seu sistema de ação que é referido e embebido nos seus valores. (DAMATTA, 1997, p. 14)

Adentrar a cidade ou a casa, ser aceito e integrar-se à vivencias particulares só é superado pela comensalidade, enquanto ato de hospitalidade.

[...] a hospitalidade e a convivência se concretizam maximamente na comensalidade. Báucis e Filêmon ${ }^{10}$ preparam a comida com o melhor que possuíam, os pães, os legumes, os ovos, o óleo, o vinho e o último pedaço de toucinho para a sopa. E, por fim, a sobremesa de tâmaras e figos secos. A preparação não é mecânica. É um ritual, pois, inconscientemente, sabemos que a comida é mais do que comida. É a participação nas energias que dão vida ao universo e a todos nós e é comunhão entre os comensais. Ela nunca é apenas nutrição mas consumação de uma relação e de uma convivência. (BOFF, 2005, p. 100)

Admitir o estrangeiro em uma mesa é a comprovação da aceitação e do desejo de compartilhar o que se tem e de abrir-se mostrando quem realmente se é. Através da alimentação pode-se observar os hábitos e crenças de uma sociedade inteira. As preferências alimentares são geralmente influência da convivência e na maioria das vezes transmitidas de mães para filhos no ambiente da casa. $O$ ato de se alimentar é mais que uma necessidade fisiológica que nutrirá o corpo. Segundo o chefe de cozinha Alex Atala ${ }^{11}$ a receita ideal para conhecer um lugar e sua cultura é através da proximidade com as pessoas que lá vivem e acrescenta "a melhor aproximação é a que se dá quando se senta à mesa com elas. A intimidade que comer junto propicia talvez só seja superada pela experiência de cozinhar junto" (ATALA, 2003, p. 16).

Ainda, em sua fala no Cozinha Show no XIII Salão de Alimentação "Alimenta" realizado em Brasília/DF em junho de 2014, o chef Alex Atala nomeou a

\footnotetext{
10 Mito da tradição grega fundamental da hospitalidade transmitido pelo poeta romano Públio Ovídio (43-37 d.C.), chamado As Metamorfoses, onde Filêmon (em grego, amigo e amável) e Báucis (delicada e terna), os esposos hospitaleiros recebem Júpiter (pai-criador do céu e da terra) e seu filho Hermes. (BOFF, 2005)

11 Chef de Cozinha brasileiro considerado em 2014 pela revista britânica Restaurant como o chef do ano e seu restaurante D.O.M classificado em sétimo lugar na premiação anual dos 50 melhores restaurantes do mundo promovida pela The World's 50 Best Restaurants Awards 2014.
} 
comensalidade (comer e beber juntos) como "a maior rede social do mundo" e acrescentou que no meio da relação entre cultura e comida, está a natureza. Adepto da defesa e salvaguarda dos produtos brasileiros o chefe de cozinha valoriza e potencializa o uso dos sabores, cores e ingredientes do Brasil através não apenas de seus restaurantes como também do Instituto ATA, onde manifesta sua intenção de rever a relação do homem com o alimento em prol de se comer e viver melhor através do uso racional e científico dos recursos naturais.

Montanari (2008) traz a semântica da palavra convívio para argumentar o quanto o viver junto se relaciona com o comer junto (cum-vivere). "Em todos os níveis sociais, a participação na mesa comum é o primeiro sinal de pertencimento ao grupo" (MONTANARI, 2008, p. 159).

Dificilmente será encontrado em uma mesa representações do que não se é, ou, do que não se deseja parecer ser. O que comer na próxima refeição é um dilema do onívoro humano respondido através de consulta aos sentidos e memória, costumes e tradições culinárias, receitas e tabus. O dilema trata do estabelecimento do vínculo dos humanos com tudo que os mantêm. O que os indivíduos comem os definem (POLLAN, 2007).

A mesa fixa uma ordem social, solda uma comunidade de eleitos reunidos por uma etiqueta de mesa e de conversação que, ela mesma, pereniza fundamentalmente a distinção social. Ela reúne e exclui. (GRASSI, 2011, p. 50)

Os indivíduos que se sentem pertencente a um grupo operando uma cultura, agem naturalmente de forma diferente de outro ser da mesma espécie de grupo/cultura distinta. Isso não pode ser considerado desvio de comportamento, é apenas questão de diversidade cultural. Qualquer pessoa pode se socializar em qualquer cultura existente porém "será limitada pelo contexto real e específico onde de fato ela crescer" (LARAIA, 2009, p. 62).

No contexto atual, com tamanha exclusão onde os semelhantes são beneficiados e os diferentes marginalizados, pensar e praticar a hospitalidade, a convivência e a comensalidade exige o entendimento de que suas estruturas são complexas. Essa complexidade por si só motiva o saber/fazer de maneira transversal, atingindo todas as camadas do processo relacional da sociedade. 
É preciso interpretar as culturas em toda sua complexidade. Existem muitas diferenças entre os homens, as crenças e os costumes tanto ao relacioná-los com o tempo como com o lugar, assim, imaginar a natureza humana constante e independente pode ser uma ilusão.

A evolução física do indivíduo ocorreu com a variação genética e a seleção natural. A partir daí iniciou o desenvolvimento cultural onde cada ser humano começa a vida com equipamentos naturais que possibilitam milhares de tipos e estilos de vida, porém é escolhido um único tipo de vida. A cultura funciona como um mecanismo de controle para a humanidade e o que a controla são os símbolos significantes (palavras, gestos, desenhos etc). Sem esses símbolos o homem seria um ser desgovernado em seus atos, dessa forma a cultura é condição para a existência humana.

O conceito de cultura que Geertz (1978) defende é semiótico (estuda signos e significados).

\begin{abstract}
De qualquer forma, o conceito de cultura a qual eu me atenho não possui referentes múltiplos nem qualquer ambiguidade fora do comum, segundo me parece: ele denota um padrão de significados transmitidos historicamente, incorporado em símbolos, um sistema de concepções herdadas expressas em formas simbólicas por meio das quais os homens comunicam, perpetuam e desenvolvem seu conhecimento e suas atividades em relação à vida. (GEERTZ, 1978, p. 103)
\end{abstract}

Significado, símbolo e concepção precisam de explicação, completa Geertz (1978).

Acreditando, como Max Weber, que o homem é um animal amarrado a teias de significado que ele mesmo teceu, assumo a cultura como sendo essas teias e a sua análise; portanto, não como uma ciência experimental em busca de leis, mas como uma ciência interpretativa, à procura do significado. É justamente uma explicação que eu procuro, ao construir expressões sociais enigmáticas na sua superfície. Todavia, essa afirmativa, uma doutrina numa cláusula, requer por si mesma uma explicação. (GEERTZ, 1978, p. 15)

O sentimento de afeto precisa estar presente para que se consiga pensar em um nós coletivo.

A ternura não é uma questão poética, ela é a condição fundamental para fazer uma sociedade que nos permita considerar o outro como a nós mesmos, ou seja capaz de idealizar maneiras de não-exclusão, de pensar em um mundo no qual todos sejam incluídos e humanos. (TORO, 2005, p. 54) 
Os ensinamentos de valor do coletivo vêm das organizações comunitárias e de bairro para melhorar o processo de comunicação de uma sociedade. Segundo Toro (2005) é preciso desenvolver e fortalecer os espaços sociais de convivência pois a comunicação é fundamental para a cultura democrática.

Para Toro (2005) a produtividade cultural é a capacidade que uma sociedade tem de possibilitar que o que é produzido com significado pelos diversos grupos circule e concorra em igualdade no universo do simbólico. "O conhecimento da nossa própria cultura e identidade (com suas vantagens e limitações) é condição básica para a produtividade. Essa autoafirmação é que nos permite aprender com os outros e ser produtivos internacionalmente, sem medo do que somos" (TORO, 2005, p. 38).

O modernismo, movimento da modernidade, busca redescobrir o Brasil através das raízes nacionais do passado ou da cultura popular. A década de 1930 consolida o discurso nacionalista, época em que Mario de Andrade tem no passado a fonte de conhecimento que produz inspiração para o desvendamento de tradições e possibilidades para o futuro. Os anos 60 trazem as tradições do povo como manifestações da cultura popular e não mais como folclore. Após o vazio cultural da década de 70 , os anos 80 e 90 apresentam-se com a globalização e a cultura do consumo segundo Madeira e Veloso (1999). Consumismo e mercantilização surgem do pós-modernismo e ocorrem graças às mudanças sociais ocorridas, acrescenta Burns (2002).

É no segundo momento do modernismo que se passa a buscar a essência do brasileiro para legitimar a nação moderna na busca da autopreservação, segundo Oliveira (2008). A partir de 1960 a cultura é pensada não mais como comportamentos, mas como sistema de símbolos e representação. Os principais eixos de análise de estudo contemporâneos são as práticas do cotidiano. Hoje em dia, ainda segundo Oliveira (2008) o campo de estudo da cultura popular esta renovada e reconhece o hibridismo apresentado por Nestor Canclini. Canclini (2013) acrescenta ainda a necessidade de registrar o que nas fusões permanece diferente.

Canclini (2013) parte de hibridismo não como um termo que migra da biologia para as ciências sociais, mas como um processo sociocultural onde há uma mistura de estruturas que combinadas formam uma nova estrutura. O conceito de hibridação é usado para descrever processos inter étnicos e de descolonização; globalizadores; viagens e cruzamentos de fronteiras; fusões artísticas, literárias e comunicacionais; gastronomias de diferentes origens na comida de um país; associação de instituições 
públicas e corporações privadas; museografia ocidental e tradições periféricas nas exposições universais.

Não é possível tratar a identidade apenas como um conjunto de traços fixos, nem afirmá-las como a essência de uma etnia ou de uma nação. Canclini (2013) propõe deslocar o objeto do estudo da identidade para a heterogeneidade e as hibridações interculturais. Os termos antecedentes ou equivalentes de hibridação (mestiçagem, sincretismo e crioulização), são usados em geral para referir-se a processos tradicionais, ou à sobrevivência de costumes e formas de pensamento prémodernos no começo da modernidade. A teoria da hibridação contrapõe esse fundamentalismo.

As culturas híbridas são, segundo Grinover (2007), fruto de uma modernidade tardia, presentes principalmente nas cidades de crescimento recente e acrescenta: "as identidades culturais que estão emergindo em toda parte não são fixas; estão em transição, retiram seus conteúdos a partir de diferentes tradições culturais e são produtos cada vez mais comuns do mundo urbano globalizado" (GRINOVER, 2007, p. 150).

Não existe cultura pura, intocada e estática acrescenta Burns (2002). A cultura é o todo complexo que inclui conhecimentos, crença, arte, lei moral, costumes e quaisquer outras capacidades e hábitos adquiridos pelos homens como membro da sociedade. $O$ termo adquirido significa nesse contexto o que foi transmitido de geração para geração pelo ensino aprendizado, pela interação entre as pessoas e não por transmissão genética.

Uma vez que antropólogos concordariam que a sociedade (e por conseguinte também a cultura) muda em resposta ao ambiente e à tecnologia, a implicação clara desta transmissão de conhecimento entre as gerações é que a cultura é dinâmica: todas as culturas mudam com o tempo. (BURNS, 2002, p. 77)

Não se deve tentar determinar a cultura, mas sim identificar sua importância. A cultura, segundo Geertz (1978) é um contexto que deve ser descrito com densidade. Compreender a cultura é entender o cotidiano sem reduzi-lo a particularidades.

Os estudos sobre a cultura devem fornecer subsídios para os significados das ações sociais particulares, sobre o papel da cultura na vida humana. O material de campo produzido de forma obsessiva, participativa e qualitativamente fará com que 
se pense com a sociedade e não sobre a sociedade, pois as análises culturais estão aprofundando-se nas mesmas coisas e não nas lacunas que ainda estão abertas.

Entender as relações humanas e possibilitar que o homem se (re)pense pela cultura fortalece a sociedade e por consequência a democracia. Para tanto os espaços públicos devem ser fortalecidos e fomentados. Toro (2005) apresenta a construção do público a partir do sentido coletivo em detrimento do particular onde se faz preciso pensar e ouvir o todo, pois somente assim existirá uma política responsável, digna e ética.

A construção do público deve ser considerada essencial para a criação de uma sociedade justa. As bases que edificarão essa construção são entre outros as ações de cidadania. $O$ indivíduo precisa agir e sentir-se cidadão, responsável pela construção do público, pelo fortalecimento da democracia e pelos cumprimentos dos Direitos Humanos. Deve conhecer seus direitos e deveres e conceber que a articulação com associações ou instituições contribui para que suas necessidades sejam ouvidas, possibilitando uma intervenção do Estado que de fato alcance, positivamente, suas vidas. As representações devem ser mais que ouvidas, devem ser atendidas. Não basta uma voz, é preciso um ouvido para que as diferenças sociais sejam diminuídas e comece a existir a justiça social.

A cidadania real clama a democracia moderna, ordenada, sem corrupção, que devolva a fé nas instituições e que proporcione igualdade, segurança, defesa, riquezas econômicas, sociais e culturais.

\begin{abstract}
O êxito de uma proposta de transformação social ou política depende da qualidade de, ao menos, quatro fatores: projeto, planejamento, gestão e sentido. A criação, transformação e a difusão de sentidos e significados são tarefas da comunicação e da mobilização social. (TORO, 2005, p. 83)
\end{abstract}

As sociedades evoluem e se transformam. A quantidade de informações transmitidas pelos meios de comunicação, a conectividade universal proposta pelas tecnologias e pela globalização, a facilitação e velocidade dos meios de transporte e consequentemente do turismo proporcionam aos indivíduos maiores possibilidades de transformações/adaptações. A cultura adere a essas transformações não podendo ser considerada um desvio de comportamento, já que essa é uma questão generalizada. 


\title{
3.2Reconstrução da Identidade Coletiva nas Práticas de Comensalidade da Feira da Ceilândia
}

A auto denominação da feira como nordestina, soa como uma forma de fragmentar a cidade e preservar de algum modo a identidade dos sujeitos que ali construíram seu lugar de pertencimento na lógica da exclusão, quando da construção da capital federal. Poderia ser chamado, assim como Carlos (2007) denominou, de gueto urbano ${ }^{12}$. Na multiplicidade da grande Brasília, a feira da Ceilândia é onde os nordestinos de Brasília, e/ou seus descendentes se encontravam, se reconheciam, se identificavam. A relação de pertencimento ao espaço foi criada por sua exclusão, após não terem lugar na "cidade iluminada" conforme Milton Santos (1999).

Os feirantes, que na sua maioria, são de origem nordestina ou descendentes de nordestinos, como foi relatado pelo Seu França não se identificam como parte dos fluxos de Brasília. Ao contrário, há uma imposição, uma divisão, entre eles do plano piloto e nós das áreas que foram excluídas. Se reconhecendo como nordestino onde se distinguem dos brasilienses e candangos. Referem-se a si como eu, e aos brasilienses e candangos como outro (vocês). Esse fato está claramente representado na fala do feirante de bolsas e acessórios tratada no relato etnográfico quando ele diz: "eu como bode de todos os jeitos, vocês comem um boi inteiro se deixar. Não sei que mania é essa de vocês com boi".

\begin{abstract}
A existência dos guetos aponta para as particularidades da sociedade que se impõe como o diferente, posto que reafirma as diferenças apontando possibilidades de resistência do cidadão diante da construção da identidade abstrata produzida no mundo moderno. São resíduos que se mantêm e que estipulam claramente a luta pelo direito à cidade. (CARLOS, 2007, p.48)
\end{abstract}

As fachadas de algumas bancas de comida, representadas pelas imagens 34 e 35, ao apelar para a caracterização nordestina fornecem indícios da reafirmação das diferenças criadas pelo "gueto" nordestino, conforme expressão de Carlos (2007), ou como lugar de memória onde a tradição é compartilhada.

12 Fragmentação de territórios contidos dentro da grande cidade, a partir das modalidades dos usos que contemplam características culturais, étnicas e/ou religiosas diferenciadas. (CARLOS, 2007) 


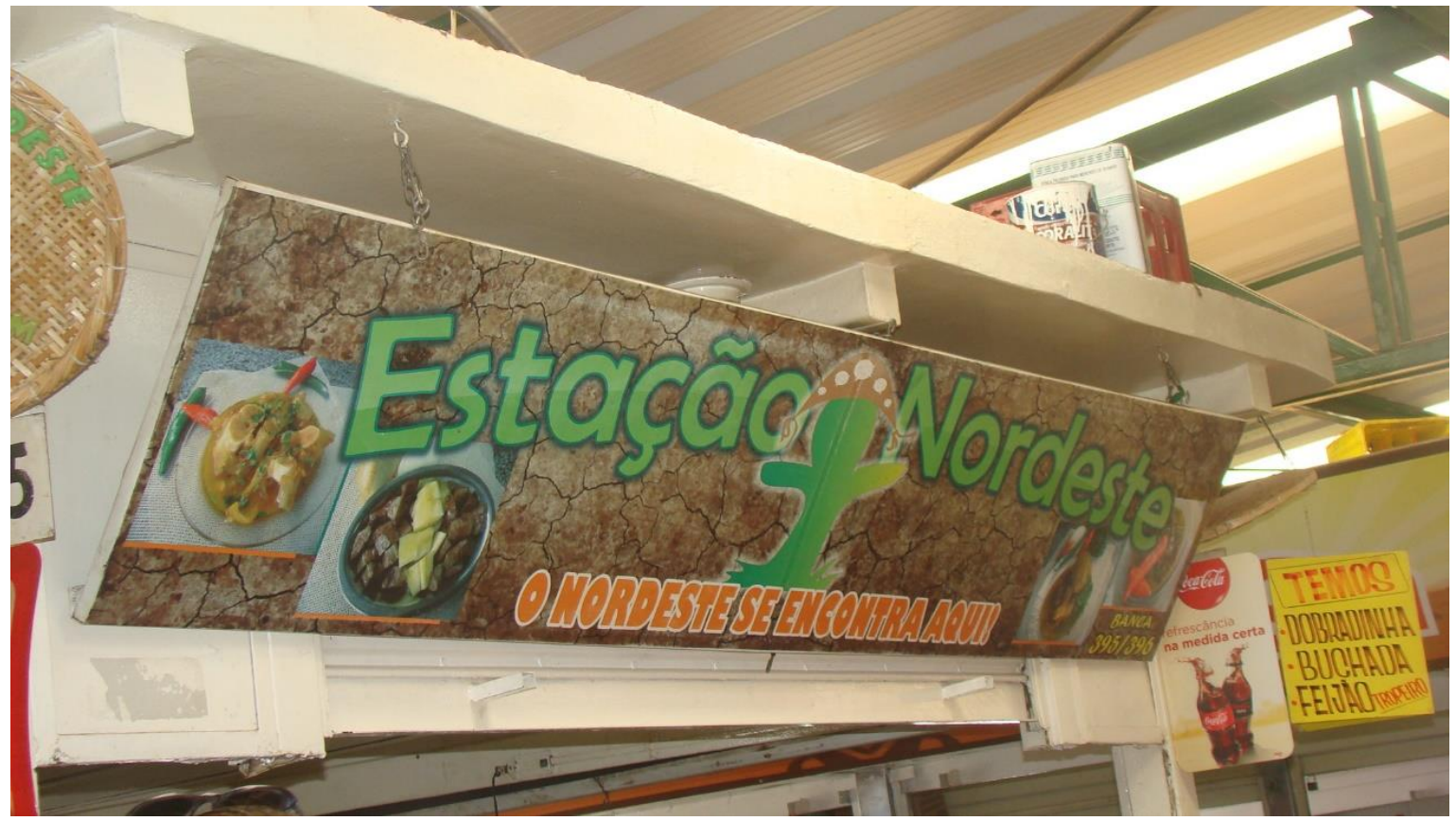

Imagem 34: Banca Estação Nordeste

Fonte: Imagem registrada pela pesquisadora em março de 2015.

Na feira construiu-se um lugar de vida diferenciado, solidário, sem muros, com relação de vizinhança, contato, convivência e hospitalidade entre feirante/feirante e feirante/frequentador. Um espaço de sociabilidade singular onde a base da hospitalidade é o resgate do outro.

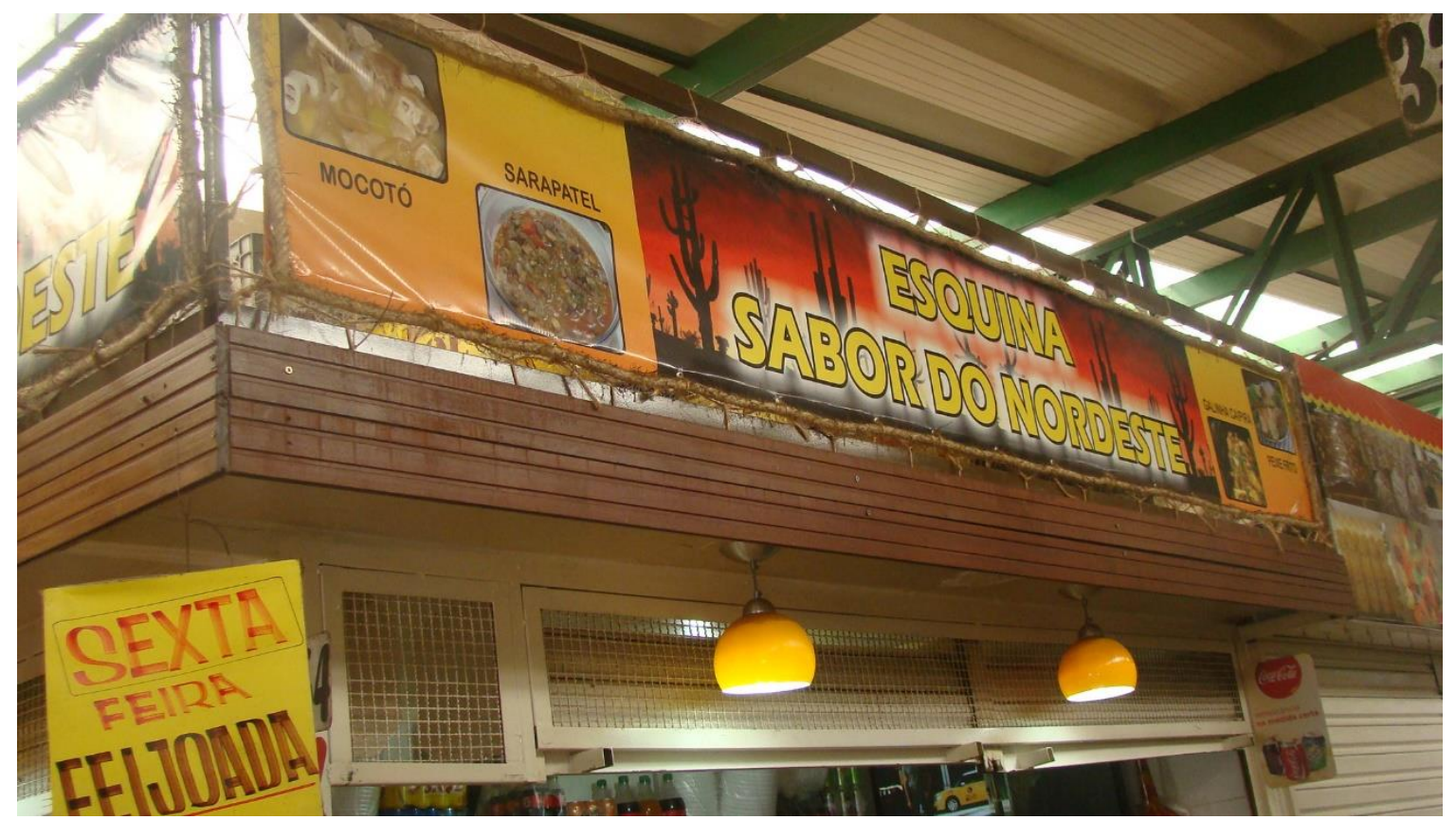

Imagem 35: Fachada da Banca Esquina Sabor Nordeste

Fonte: Imagem registrada pela pesquisadora em março de 2015. 
Há conflitos sem conta por todos os quadrantes da Terra. Como resolvê-los? Mais e mais cresce o número de analistas e de pensadores que afirmam: não será através de acertos políticos que serão solucionados mas mediante a aceitação de um pacto ético mínimo a ser abraçado por todos. Ele se fundará sobre a defesa intransigente da vida, sobre a preservação da integridade do planeta Terra e de seus ecossistemas, sobre a garantia das condições indispensáveis para a manutenção da vida de todos e sobre a decisão de exorcizar definitivamente a violência como meio de resolução de conflitos entre os povos. Essa ética mínima pressupõe a acolhida do outro como outro, o respeito por usa singularidade e a disposição para uma aliança duradoura com ele. Estes propósitos estão contidos na ideia da hospitalidade aberta e irrestrita. (BOFF, 2005, p. 151)

Diferenciado por estar em espaço púbico onde todos que desejarem podem ir para se alimentar, comprar, passear. Do Governador ao mendigo, todos coabitam o mesmo espaço. A feira possibilita a congregação das pessoas, pois historicamente os códigos e regras de conduta da feira são informais, expressões de seus atores. Mais permissivos que outros espaços, na feira os apelidos são permitidos, o contato aproximado. Como se a rua virasse casa.

Ao demarcar o lugar, com suas ações, com seu "ir e vir" no uso, para a vida, o homem se identifica com o espaço porque seus traços, suas marcas o transformam. Na convivência com o lugar, e nele se produz a identidade. (CARLOS, 2007, p. 48)

A feirante Claudete Sirino da banca Estação Nordeste ao ser perguntada sobre a relação com os clientes afirma: "a relação é de amizade mesmo, tem cliente que vai até na minha casa conversar."

Outra feirante, Maria da Banca do Carlão, respondeu a mesma pergunta contando que a relação com os clientes é tão verdadeira que passa de pai para filho e explica que como sua banca tem origem em 1973 os clientes eram os pais e hoje são os filhos. Explica que muitos dos "pais" já faleceram e hoje os clientes são os "filhos". Contou que brinca com esses clientes herdados dizendo: Te conheço há 40 anos e os filhos respondem que não entendem como, pois têm apenas 28 anos. Assim feirante e cliente divertem-se com as semelhanças entre pai e filho e reafirmam sua intimidade duradoura.

Por um lado, tem-se a tentativa de manter antigos modos de vida, de relações e de práticas, de outro lado o mundo pós-moderno bate à porta pedindo a alteração de comportamentos.

Há na feira a ocorrência de dois fenômenos contraditórios no que se refere a denominação nordestina: o estranhamento e a identificação. Estranhamento aos 
novos padrões universais impostos pela globalização, evidenciados pelas fotografias das bancas de produtos tradicionais representados pelas imagens 36 e 37 onde roupas, calçados e acessórios comercializados são réplicas do modismo global, por vezes cópias de grandes marcas.

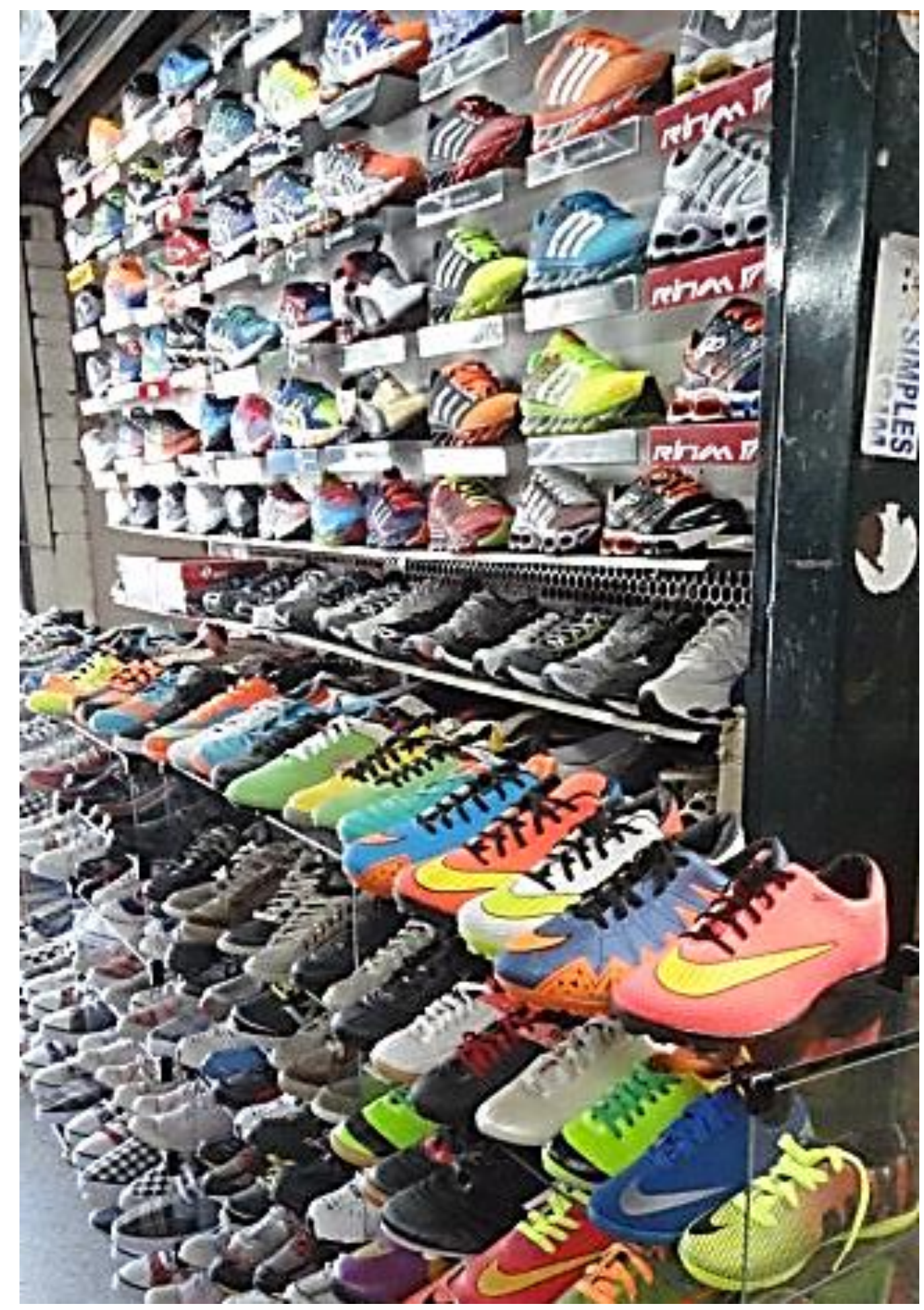

Imagem 36: Bancas de Calçados

Fonte: Imagem registrada pela pesquisadora em março de 2015. 


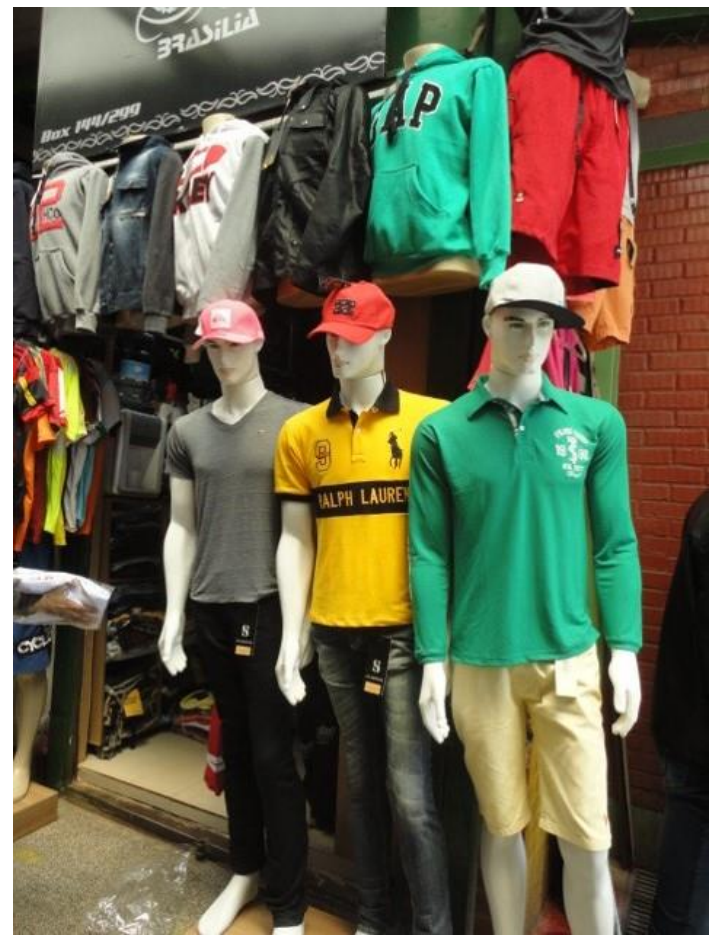

Imagem 37: Banca de Moda

Fonte: Imagem registrada pela pesquisadora em março de 2015.

A identificação com as práticas nordestinas evidenciada aqui pelo comércio de utensílios (Imagem 38), temperos e ervas (Imagem 39) e comidas (Imagem 40) característico do comercio tradicional no Nordeste brasileiro. Uma identidade complexa se configura na prática do viver, local e global, que liga pontos distantes e não tão distantes.

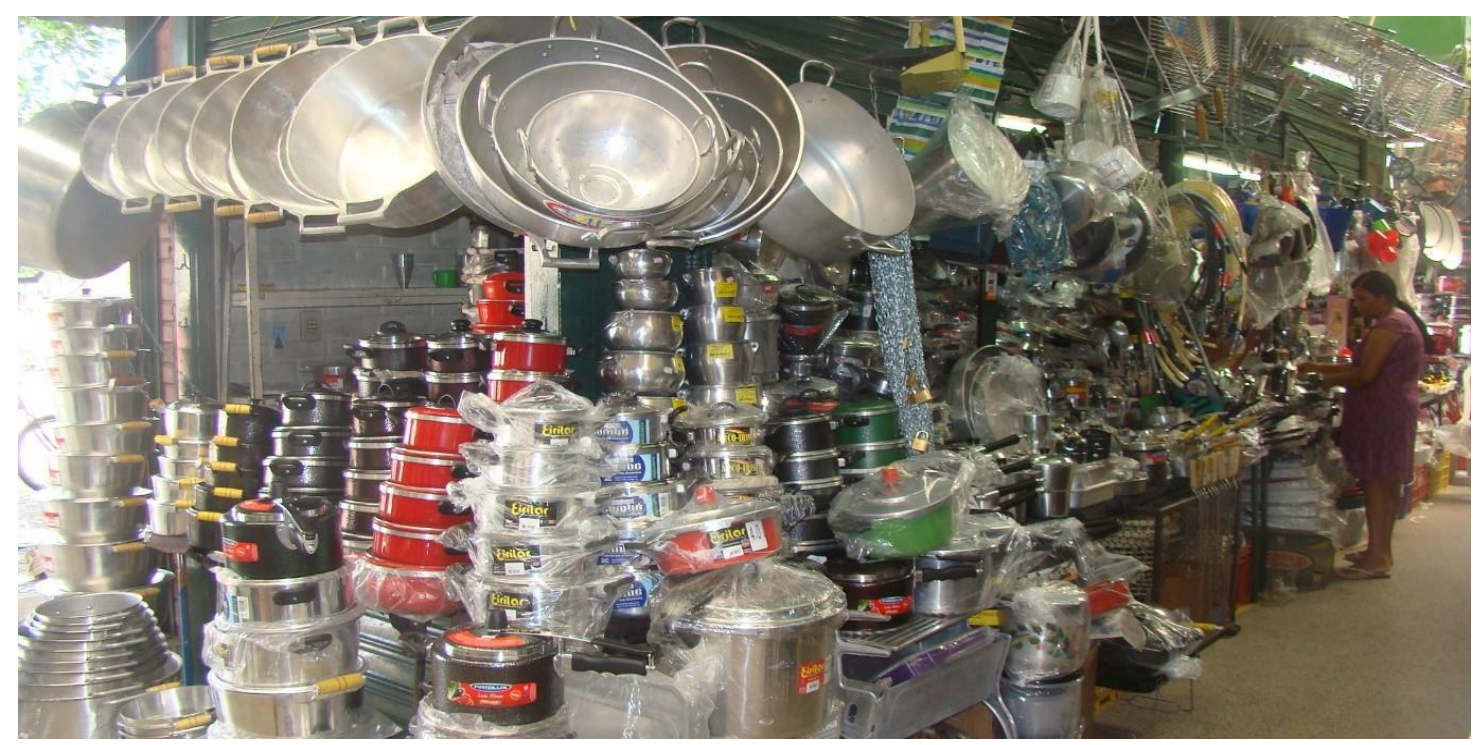

Imagem 38: Banca de Utensílios

Fonte: Imagem registrada pela pesquisadora em março de 2015. 


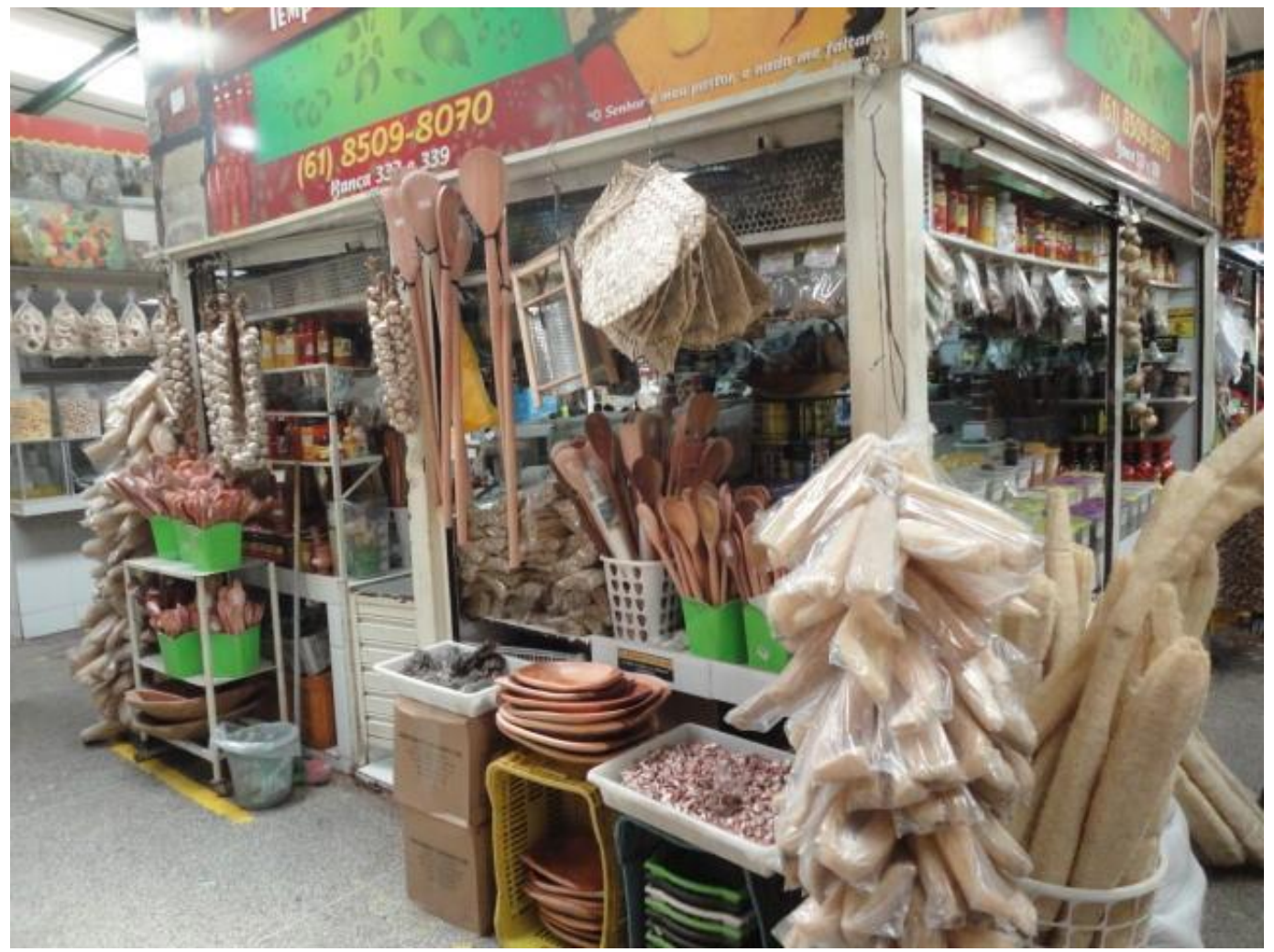

Imagem 39: Banca de Temperos

Fonte: Imagem registrada pela pesquisadora em 25 de março de 2015.

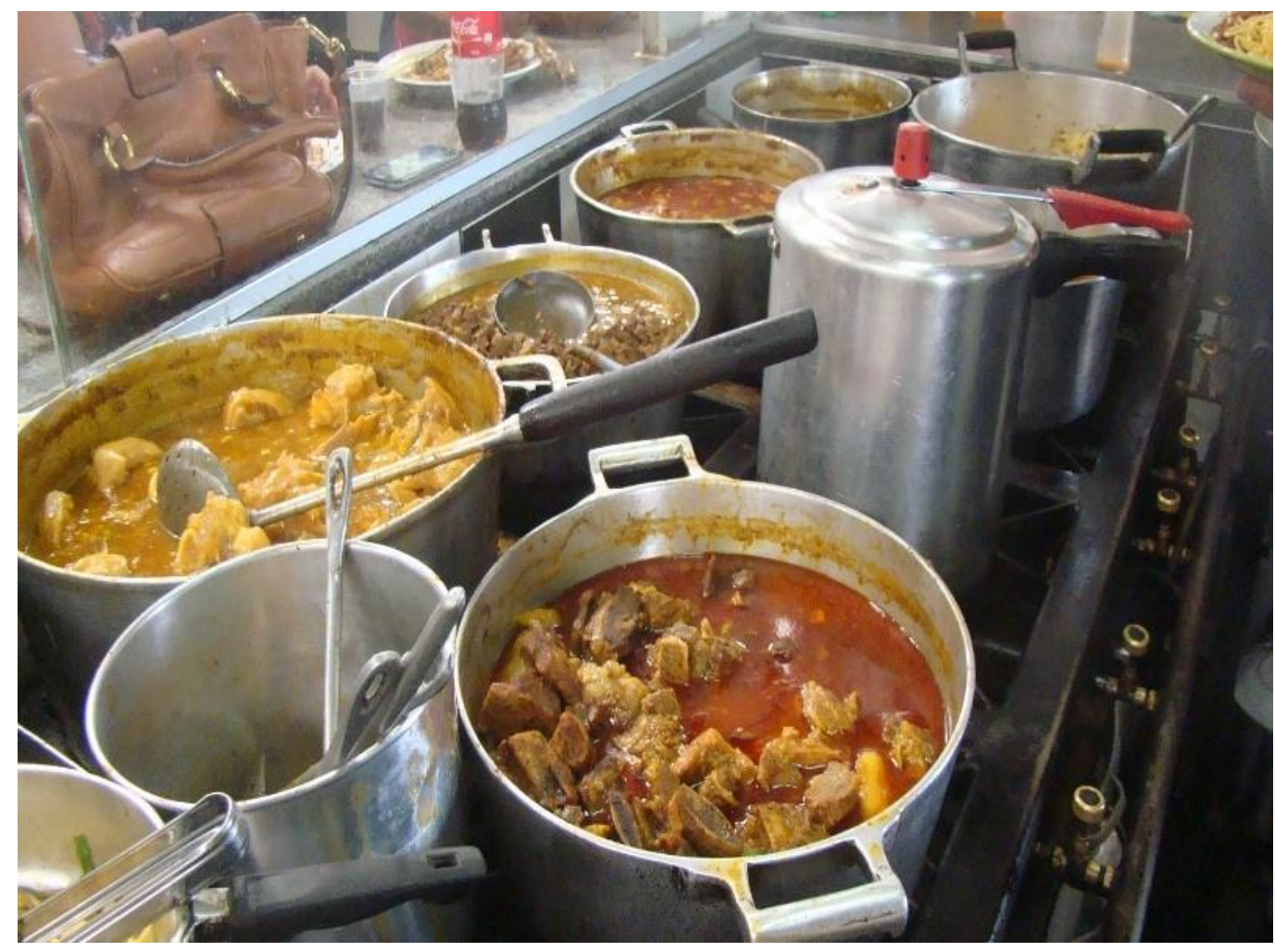

Imagem 40: Comidas Típicas

Fonte: Imagem registrada pela pesquisadora em 29 de março de 2015. 
O homem moderno está dominado pelo valor da troca, talvez porque o aumento de poder de compra da sociedade requeira a multiplicidade de objetos produzidos e com vida útil cada vez menores, onde sequer a origem interesse. Antes sabia-se de onde os produtos vinham, existia uma relação entre produtor e comprador. "A mercadoria parece assim como figuras autônomas dotadas de vida própria em relação aos homens. No mundo moderno essa situação atingiu o seu limite" (CARLOS, 2007, p. 77).

De valor de uso e signo por uma necessidade agora a lógica é a da moda ou a do prestígio. Nesse contexto a feira Permanente da Ceilândia não ficou imune. Espaço múltiplo, de encontro, convívio, hospitalidade, comensalidade e consumo a feira tenta sobreviver econômica e socialmente. Porém, por hora, na feira, a relação com os objetos de consumo não substituiu a relação com as pessoas conforme relatos:

Marco Aurélio, piauiense de 30 anos de idade veio morar no Distrito Federal em 2011. Hoje morador do Sol Nascente frequenta a feira semanalmente há quatro anos. Procura a feira por considerar ser bem tratado no atendimento pelos feirantes e porque as comidas nordestinas o fazem lembrar sua cidade natal, Cristalândia/PI. Relatou ainda que seu prato preferido é a buchada e que se não come-la na feira da Ceilândia no DF comeria apenas nos bares e restaurantes do Piauí.

O relato etnográfico da feira expôs a forma com que a pesquisadora foi recebida por feirantes, a relação de intimidade e proximidade estabelecida entre frequentadores e pesquisadora o que somado as falas de Admar Santos e Marco Aurélio evidencia que a feira se apresenta como um espaço de hospitalidade e comensalidade pela forma com que acolhe seus frequentadores, sejam eles moradores da localidade, do Distrito Federal, turistas, estrangeiros, visitantes ou viajantes.

Nessa pesquisa, hospitalidade foi ressignificada com Boff e Grassi como o acolhimento primeiramente ao morador da localidade para posteriormente bem acolher o estrangeiro em espaço de contemplação e socialização que possibilite ao indivíduo a construção de sentimento de pertencimento a um lugar, a um grupo, a uma cidade.

O relato de Admar Santos, goiano, 60 anos, frequenta a feira há três anos por ser "muito bem tratado". Disse ainda que não sabe onde comeria sua comida nordestina preferida, a dobradinha, se não for na feira da Ceilândia. Contou ainda que 
caso a dobradinha fosse ofertada na praça de alimentação de um shopping center não comeria lá por acreditar que a dobradinha "é coisa de feira".

$\mathrm{Na}$ comensalidade, o sentar-se à mesa para a refeição não significa apenas o momento de comer e beber, mas o de viver e partilhar essa experiência com códigos e regras estabelecidos.

$\mathrm{Na}$ feira os códigos e as regras são a informalidade, o despojamento, o assunto sem censura. A comensalidade admite nesse estudo o comer e beber junto, construindo e afirmando uma identidade coletiva promovendo laços sociais e partilhando uma maneira de viver cujo primeiro indício de pertencimento a um grupo é a participação da mesa comum, no caso da feira os bancos próximos.

Consumir signos e significados é também consumir signos de exclusão.

Ao consumir um produto em determinado lugar opta-se por não consumir outro em outro lugar, ao menos no dado momento. Ao adquirir e exibir, através do uso, um calçado de marca estrangeira se pretende ou fazer parte de um grupo que também usa esses tipos de calçados estrangeiros ou se pretende negar os grupos que não o utilizam. Ao consumir o mocotó na feira o sujeito está negando a comida estandardizada de fast foods e se identificando com a comida nordestina, e demais comensais e práticas do viver da feira.
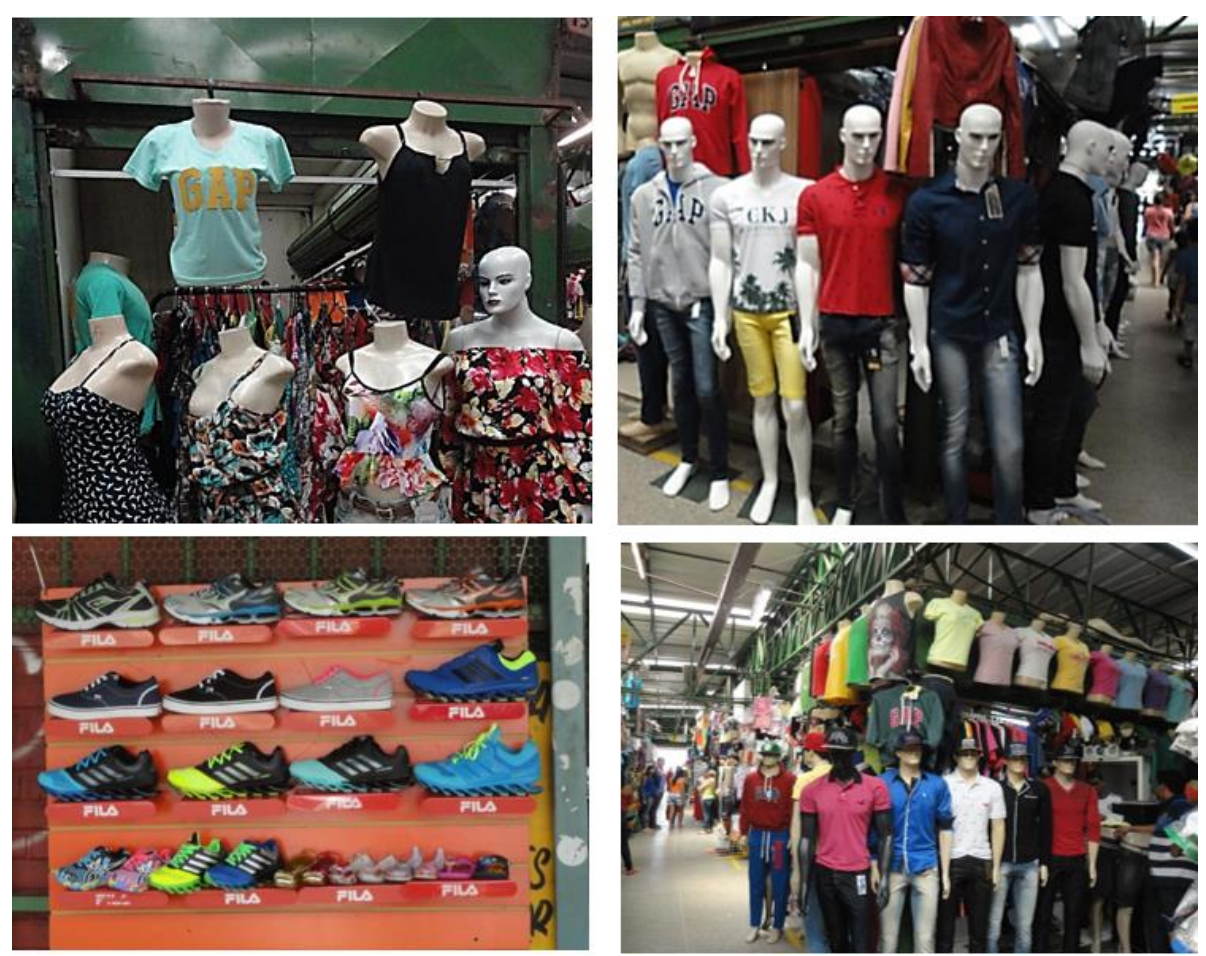

Imagem 41: Bancas de modismo global da Feira da Ceilândia Fonte: Imagens registradas pela pesquisadora em março de 2015. 
Retomando Bourdieu (2011), para compreender a luta pela definição da identidade regional, no caso desse estudo a nordestina, deve-se ir buscar mais profundamente as motivações das representações incluindo no real as representações do real, a luta de representações (as manifestações sociais destinadas a manipular as imagens mentais).

As lutas a respeito da identidade étnica ou regional, quer dizer, a respeito de propriedades (estigmas ou emblemas) ligados à origem através do lugar de origem através dos sinais duradoiros que Ihes são correlatos, como o sotaque, são um caso particular das lutas das classificações, luta pelo monopólio de fazer ver e fazer crer, de dar e receber e de fazer reconhecer, de impor as visões legítimas das divisões do mundo social e por esse meio, de fazer e desfazer os grupos. Com efeito o que nelas está em jogo é o poder de impor uma visão de mundo social atreves dos princípios de divisão que, quando se impõe ao conjunto do grupo realizam o sentido e o consenso sobre o sentido e, em particular, sobre a unidade e identidade do grupo, que fazem a realidade e a unidade do grupo. (BOURDIEU, 2011, p. 113)

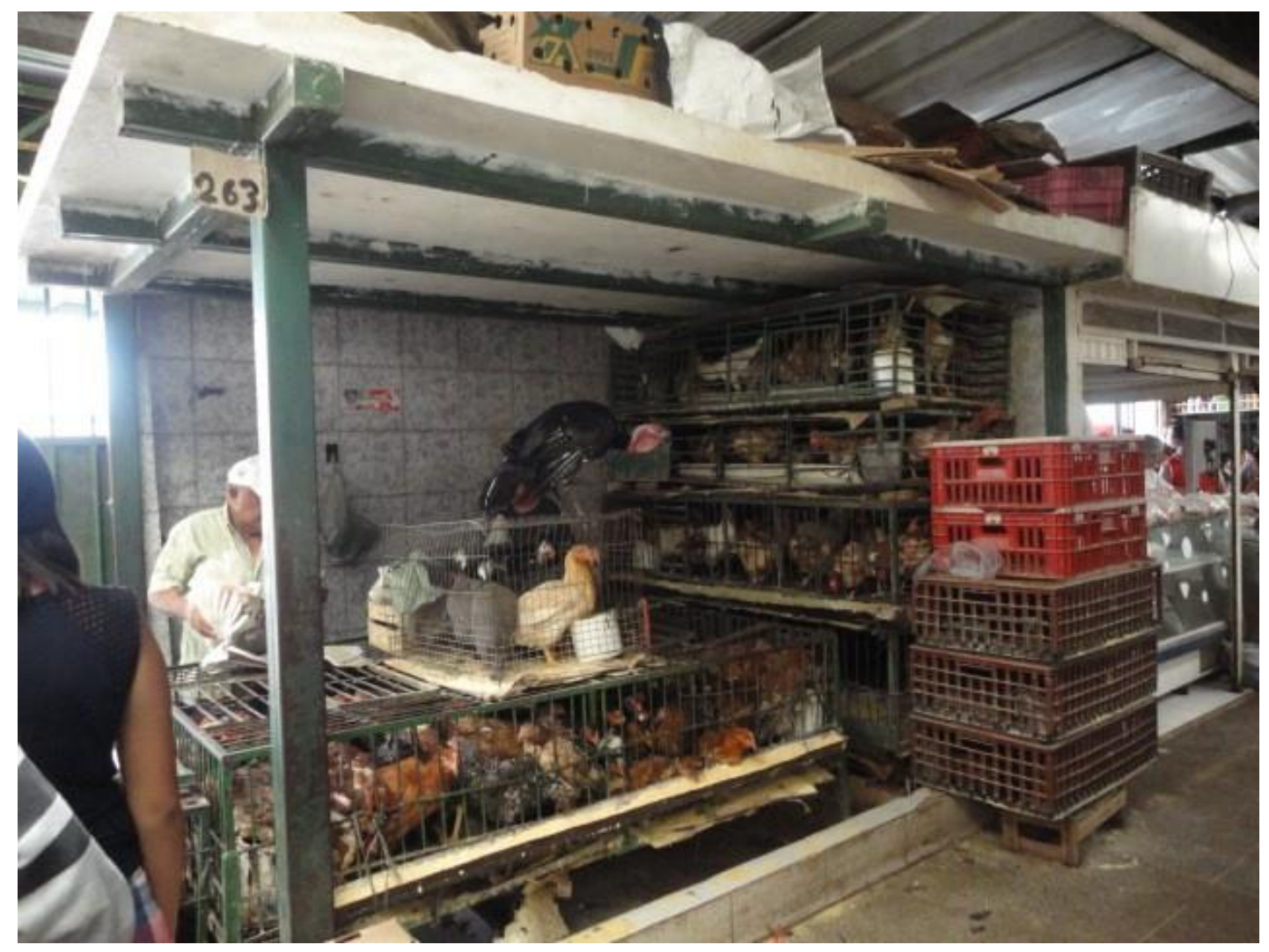

Imagem 42: Banca de Aves Vivas

Fonte: Imagem registrada pela pesquisadora em março de 2015.

Repetir e imitar padrões apresentados na TV, nas revistas e/ou na internet, propõe o pertencimento àquele grupo pulverizando o sujeito que agora não está mais 
no seu local de origem, se uniu a outros e se tornou o outro. É o princípio de hibridismo de Canclini onde estruturas se misturam formando uma nova estrutura. Na imitação coletiva, o sujeito sobrevive, pois isolado não sobreviveria. O que se testemunha na forma de comercialização dos produtos pelos vendedores das barracas é a forma diferenciada da comunicação táctil.

"Fala freguesa!

Está procurando o que hoje amiga!

Vamos almoçar amiga?

Hoje está especial!

Quer que arrume um lugar pra você?

Hoje você tem que comer aqui!"

Contudo a feira não suporta o isolamento e comercializa o simulacro de produtos globalizados como roupas da Nike, calçado da Adidas, a bebida Coca-Cola ou a batata-frita promovendo a despersonalização do espaço enquanto tipologia regional nordestina. Porém, não são simbologias suficientes, pois frequentadores e feirantes continuam se identificando e pertencendo àquele espaço dito como nordestino. Mesmo estando inseridos no processo de globalização, a feira, simbolicamente representa um elo de ligação o mais próximo de suas realidades passadas, de suas memórias e de sua identidade de origem.

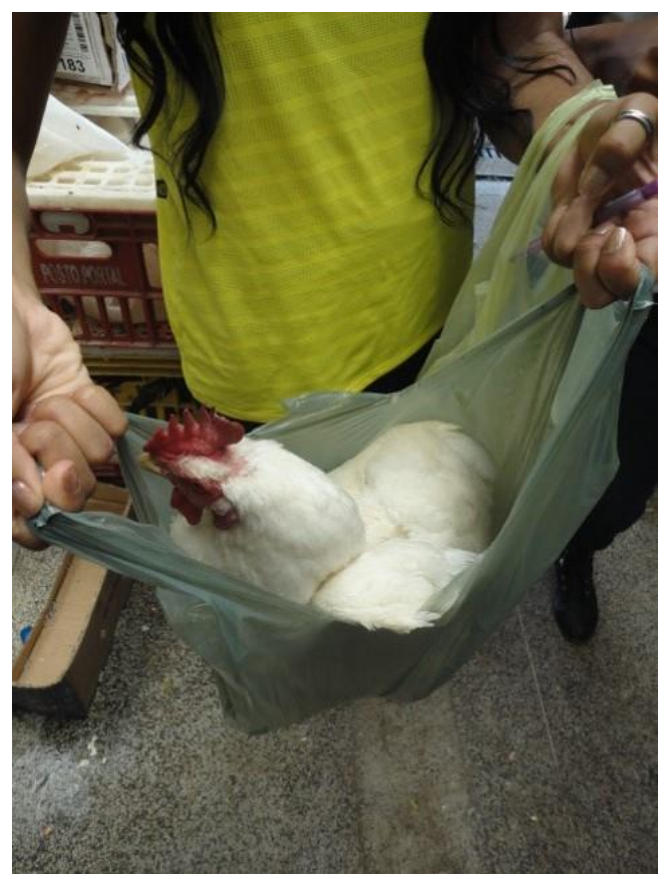

Imagem 43: Galinha adquirida na banca de aves vivas Fonte: Imagem registrada pela pesquisadora em março de 2015. 
Segundo Bourdieu (2011) quando os dominados entram na luta simbólica em estado isolado (vida cotidiana) aceitam a definição dominante da sua identidade ou da imagem de si o mais próximo da identidade legítima.

\begin{abstract}
A revolução simbólica contra dominação simbólica e os efeitos de intimidação que ela exerce tem em jogo não, como se diz, a conquista ou a reconquista de uma identidade, mas a reapropriação coletiva deste poder sobre os princípios de construção e de avaliação da sua própria identidade de que o dominado abdica em proveito do dominante enquanto aceita ser negado ou negar-se (e negar os que, entre os seus, não querem, ou não podem negarse) para se fazer reconhecer. (BOURDIEU, 2011, p. 125)
\end{abstract}

Não seria tal identificação nordestina resultado da tentativa de nomear uma identidade vivida e não concebida, abstrata, homogênea sugerida por um lugar jovem que abriga dezenas de outras identidades como na formação do Distrito Federal?

Nesse sentido a vivencia e convivência na feira da Ceilândia de sujeitos de maioria nordestina levam o indivíduo a sentir-se pertencente àquele grupo auto denominado nordestino. $O$ conceito de pertencimento reconstruído nessa pesquisa, a partir dos autores Grinover e Augé, pauta-se no desejo do sujeito de se identificar, se relacionar, sentir-se ator das histórias ali ocorridas fazendo parte de um grupo, de um lugar, de uma cidade.

Com os autores Boff e Boutaud a convivência é ressignificada como a forma globalizada e inclusiva de vivenciar a experiência humana. Partilhar a vida e coexistir junto com o outro, "trata-se de uma vivencia vivida sempre com os outros (con) e jamais sem os outros" (BOFF, 2006, p.32).

A experiência da vida coletiva vivida na feira da Ceilândia provoca a resistência, expressa por um espaço que galgue novas posições na vida da Região Administrativa de Ceilândia, que em muito se modificou nos últimos 15 anos. Como se a coesão do grupo que ali convive estivesse pautada nos dizeres da placa da entrada da feira: encontro de nordestinos.

A força simbólica da denominação nordestina é um dos fatores que preservará o lugar de memória, apesar da hibridização de sua composição, entendendo aqui por hibridização cultural um processo sociocultural onde há uma mistura de estruturas que combinadas formam uma nova estrutura.

A denominação nordestina, mais do que ser a mantenedora da coesão social, apresenta-se como camufladora, ou forjadora, de uma tentativa de resistência e sobrevivência identitária, uma vez que, nos achados apresentados nos capítulos 
anteriores, os saberes e fazeres das práticas gastronômicas preparadas e comercializados na feira são influenciados pela tradição regional nordestina. Os pratos do cardápio são adaptações, cópias não fidedignas, com substituições de modos de fazer e ingredientes.

A Imagem 44 apresenta a montagem de um prato de uma das bancas de culinária nordestina. Rabada, buchada e/ou mocotó, por exemplo, são servidos com feijão, macarrão e em alguns casos até mesmo com batata-frita configurando que a culinária tradicional nordestina praticada na feira não ficou imune à globalização.

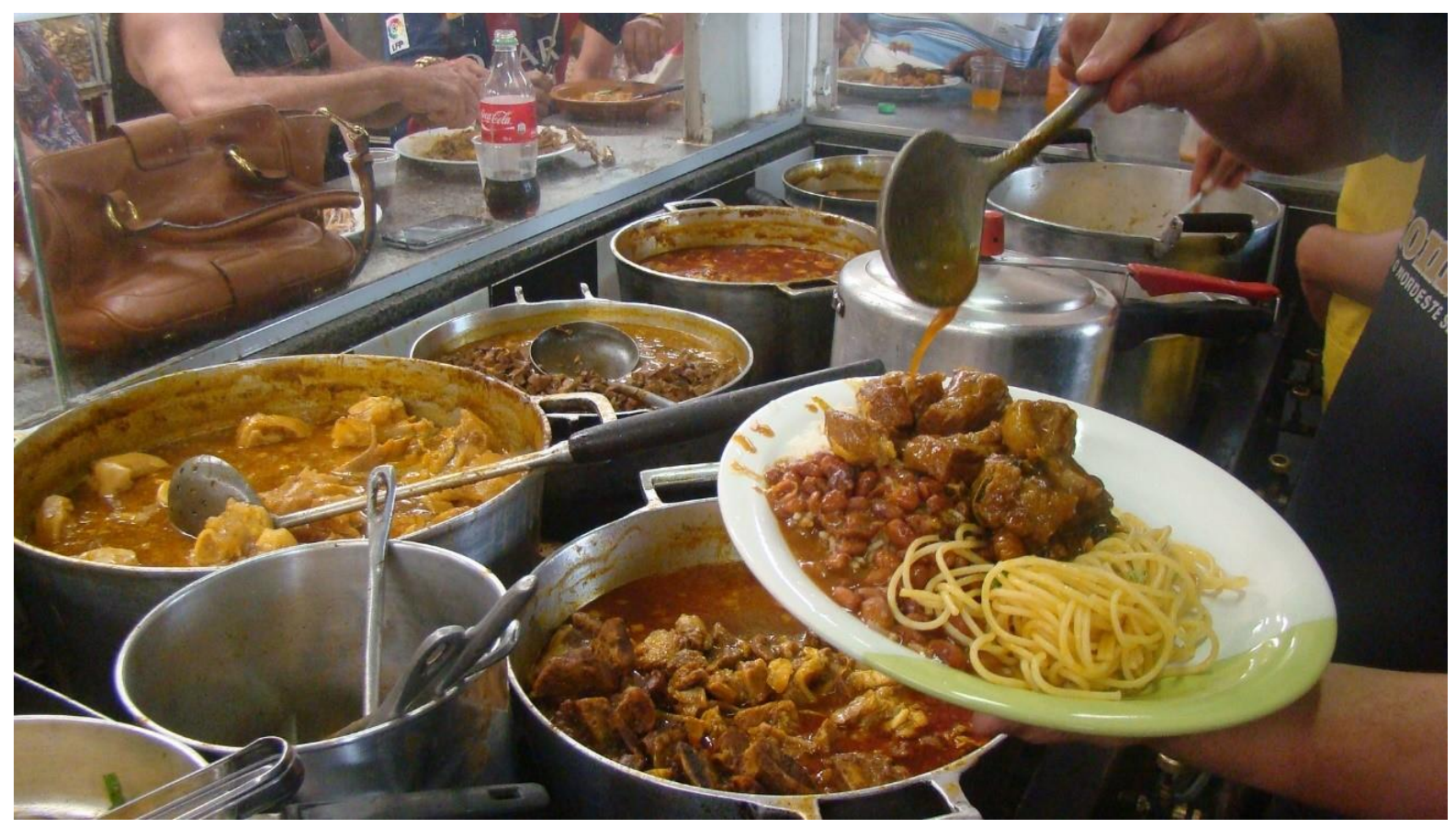

Imagem 44: Montagem de Prato de Comida

Fonte: Imagem registrada pela pesquisadora em 29 de março de 2015.

A Tabela 8 encontrada na página 95 sobre o Modo de preparo do Mocotó das bancas da Feira da Ceilândia, demonstra as variadas formas de modo de preparo e ingredientes utilizados para produzir o mesmo prato. O mocotó recebe então diversas e diferentes versões dependendo da banca e de quem a prepara que são diversas ainda do modo de preparo e ingredientes utilizados na receita do Mocotó de Vaca da coleção das receitas brasileiras e europeias no final do século XIX e início do século XX do livro Cozinheiro Nacional de Carlos Alberto Dória.

Dória (2008) apresenta entre tantas receitas do que se comia no final do século XIX e início do século XX na corte, nas províncias e no interior do Brasil, a do 
mocotó. Dória pretendeu instituir com essas receitas uma culinária brasileira baseada nos sabores da terra, ainda que baseado na lógica de organização da cozinha clássica francesa. Vale ressaltar que no período citado o estilo de se alimentar não era generalizado ao ponto de "possibilitar" uma classificação regional. Moquecas e Vatapás aparecem referidas, porém a cozinha baiana sequer existia.

\begin{abstract}
MOCOTÓ DE VACA: Escalda-se em água quente uma mão ou pé de vaca e, depois de raspado e tirado o casco, corte-se em pedaços por todas as juntas; ponham-se estes sobre o fogo com algumas peles de toucinho, sal, pimenta, salsa, louro, e deixem-se ferver a fogo vivo, durante seis horas; tirem-se depois os pedaços de mocotó e as peles, deixando-se o caldo engrossar. Quando estiver quase no ponto, deitem-sse-lhes uma colher de mostarda e um pouco de vinagre, ou sumo de limão, e sirva-se. (DÓRIA, 2008, p. 96)
\end{abstract}

O desafio do historiador da alimentação é explicar como o ideal culinário se desestrutura ao mesmo tempo em que se forma uma representação multiétnica, se diferenciando, segundo Dória (2008, p. 26):

[...] a partir da descrição de seu caráter segundo parcelas do território, de modo a se auto-representar toscamente num mosaico de cunho regionalista, mais coerente com o modelo político da República Velha do que da diversidade de sabores que o país oferece.

Os diversos modos de preparar o mocotó, prato escolhido para análise por ser o mais consumido na feira, evidenciam que adaptações e substituições foram realizadas a fim de, conforme consta no relato etnográfico, agradar aos comensais ao adaptar as preparações a seus paladares/gostos, e ainda ao fato de que as receitas foram aprendidas com pessoas diversas, em tempos diferentes e de variados estados do Brasil.

Pimentão, pimenta de cheiro, pimenta do reino, corante, coloral, açafrão da terra, caldo de galinha, coentro, louro e mandioca para engrossar o caldo são ingredientes que aparecem, na Tabela 8, em uma e outra receita do mocotó servido na feira, configurando assim que todas as preparações diferem entre si e diferem ainda da receita apresentada por Dória (2008). Essas adaptações mais que comprovar a substituição de ingredientes ou adaptação de modos de fazer do mocotó reforçam a manifestação da hibridização nas práticas culinárias da feira pois cada feirante/cozinheiro prepara o prato baseado nos seus saberes e nos gostos e preferencias de seus clientes. Assim, mais do que se pensar em adaptação ou 
substituições pode-se pensar em emancipação da tutela nordestina favorecendo então o "caráter" culinário desse local.

"As construções do passado dissolvem-se e se refazem nas construções do presente sempre que o espírito inventivo preside a interrogação do real que se dispõe como possibilidade" (DORIA, 2008, p. 26).

Mais do que o tempero utilizado nas preparações de cada banca 0 frequentador se identifica é com o feirante e com a maneira como o feirante o trata. Por diversas vezes aparecem nos achados com os frequentadores o relacionamento de proximidade propiciado pelo ambiente da feira.

Luis Carlos da Silva, brasiliense filho de cearenses, residente da RA Águas Claras é um adepto de feiras. Frequenta a feira da Ceilândia há mais de 15 anos e diz: "Feiras são diferentes de outros lugares. Feira é vida. Na feira as pessoas estão."

Luis vai a feira da Ceilândia, como tantos outros praticar a comensalidade, "tomar caldo de mocotó, falar mal do Estado, conversar, chorar as mágoas e essas coisas". Permanece na feira pelo espaço de tempo de "algumas cervejas" e compra temperos, peixe fresco e pimenta.

$\mathrm{Na}$ comensalidade, o sentar-se à mesa para a refeição não significa apenas o momento de comer e beber, mas o de viver e partilhar essa experiência com códigos e regras estabelecidos.

$\mathrm{Na}$ feira os códigos e as regras são a informalidade, o despojamento, o assunto sem censura. A comensalidade admite nesse estudo o comer e beber junto, construindo e afirmando uma identidade coletiva promovendo laços sociais e partilhando uma maneira de viver cujo primeiro indício de pertencimento a um grupo é a participação da mesa comum, no caso da feira os bancos próximos.

Tenta-se, sob uma ação controladora, com a aparência da liberdade, lutar para que o lugar de memória produzido pelos nordestinos não perca o sentido de ser nordestino.

Há na feira um ator em particular que realizou ações expressivas que possibilitaram e até mesmo garantiram a continuidade do espaço. Historicamente é uma direção, simbólica e politicamente eleita, que coordena e exerce liderança sobre o espaço há 17 anos.

O presidente da Associação dos Feirantes da Ceilândia, reeleito em 2013, se autodenomina autoridade de uma memória e de uma tradição. Seu França, conforme relatou Francinaldo Sousa da banca Kome in Pé, sente-se o guardião da tradição 
nordestina da feira da Ceilândia e rejeita a ideia que essa tradição possa ser reinventada. Rejeita a demanda por internet, música ambiente, atividades culturais ou qualquer outra atividade que apresente a feira da Ceilândia de forma diferente do que ela foi nesses 31 anos.

Para Francinaldo é preciso que os feirantes da feira da Ceilândia acreditem que outras pessoas, além do Seu França, são capazes de presidir a associação e que estas novas lideranças também representarão e zelarão pela integridade simbólica nordestina da feira.

Francinaldo continua, afirmando que a placa na entrada da feira (encontro dos nordestinos) deveria ser substituída, pois nem só de nordestino a feira é formada, nas palavras dele: "por que só nordestino? E os mineiros? E os brasilienses? E as outras pessoas que frequentam ou querem frequentar a feira?".

As indagações de Francinaldo, feirante da feira da Ceilândia há 25 anos são respondidas pela categoria de hibridização, onde a reinvenção da tradição faz parte da hibridização.

A representação como realidade de um lugar depende do conhecimento e reconhecimento. Regionalizar é dividir, descontinuar. É uma ação de direito que deve ser o pronunciamento de uma verdade dita por autoridade delegada, não pelo autoritarismo, legitimada pela força do poder regulador de uma presidência de associação. Assim, por ser uma expressão legítima e legitimada produz a existência do que enuncia.

Segundo Bourdieu, as classificações por mais baseadas no natural que sejam não são naturais, são "[...] em grande parte, produto de uma imposição arbitrária, quer dizer, de um estado anterior de relação de forças no campo das lutas pela delimitação legítima" (BOURDIEU, 2011, p. 115).

Os que pretendem propor os critérios baseados na realidade para a luta pela classificação devem compreender que se trata de um único estado da luta pela classificação. Por desejo de se classificar nesse ou naquele modo de classificação pode-se incorrer no erro de utilizar a autoridade para fundamentar, arbitrariamente, a divisão que se quer impor:

O discurso regionalista é um discurso performativo, que tem em vista impor como legítima uma nova definição das fronteiras e dar a conhecer e fazer conhecer a região assim delimitada - e, como tal, desconhecida - contra a definição dominante, portanto, reconhecida e legítima que a ignora. (BOURDIEU, 2011, p. 116) 
Segundo Bourdieu (2011) o poder sobre um grupo enquanto grupo é o poder de impor ao grupo visões, divisões e identificações que leve o grupo a uma visão única de sua identidade.

O que está em jogo é a luta pela identidade e identificação. Ao oficializar as palavras e na ânsia de se sentir reconhecido e pertencente àquele grupo particularidades são subtraídas e o discurso oficializado publicamente torna-se uma forma de manifestação do grupo ato que torna o grupo visível para ele e para os outros. Dessa forma o manifesto atesta a existência do grupo como grupo conhecido e reconhecido:

"O mundo social é também representação e vontade, e existir socialmente é também ser percebido como distinto" (BOURDIEU, 2011, p. 118).

As culturas e identidades regionais são representações, certas vezes opressoras, do poder simbólico. Retomando Bourdieu (2011), compreender a luta pela definição da identidade regional, no caso desse estudo a nordestina, deve-se ir buscar mais profundamente as motivações das representações, incluindo no real as representações do real e a luta de representações (as manifestações sociais destinadas a manipular as imagens mentais). As propriedades simbólicas, que 0 sujeito social não pode ignorar podem ser usadas estrategicamente em função dos interesses materiais e simbólicos de seu portador.

"Ao desatar los nudos de este discurso monotético y liberarnos de sus rígidas determinaciones, surge una nueva estructura más abierta, discontinua e histórica" (CHAMBERS, 1995, p. 106).

Preservar a singularidade de uma cultura é paradoxalmente a negação de sua dinâmica histórica. Isso significa que os indivíduos estão absolvidos por redes cada vez maiores e mais complexas de negociação e interação cultural.

Os brasilienses são interseção, encontro e diálogo contínuos que acentuam as potencialidades e as impurezas de rígidas determinações regionais.

Rejeitar a perspectiva etnocêntrica da história, identidade ou cultura conduzem ao desarranjamento dos núcleos relacionais da história, da identidade ou da cultura porem não desvelam o que é autentico, nativo, puro. Os atores da feira da Ceilândia ao reafirmarem a identidade e identificação nordestina da feira nos dizeres comunicados na fachada do espaço: Ponto de encontro dos nordestinos (imagem 10), e/ou, nas fachadas das bancas de alimentação conforme imagens 30 e 31 estão transgredindo ao que eles próprio defendem, a cultura nordestina, pois, a feira da 
Ceilândia não expressa a representação das feiras localizadas em cidades nordestinas como a Feira de Caruaru ou o Mercado São José, em Recife.

O papel que a feira desempenha é o de utilização de espaços públicos no qual esse espaço é construído e reconstruído constantemente por uma comunidade que foi originada por $51,73 \%$ de habitantes do próprio Distrito Federal, e $48,27 \%$ constituídos por imigrantes, segundo os dados demográficos onde $66,4 \%$ dos $48 \%$ da população imigrante segundo a naturalidade são oriundas dos estados da região Nordeste do país: Alagoas $(0,29 \%)$, Bahia $(13,05 \%)$, Ceará $(9,88 \%)$, Maranhão (11,71\%), Paraíba (10,35\%), Piauí (14,05\%), Pernambuco (3,68\%), Rio Grande do Norte $(3,39 \%)$ e Sergipe $(0,03 \%)$, formando $66 \%$ dos imigrados. Assim, $32 \%$ dos habitantes de Ceilândia são naturais do Nordeste segundo a tabela 7 na página 67.

Nesse contexto a denominação nordestina deveria pretender representar culturas e identidades dos nove estados da região Nordeste do Brasil.

Na prática do saber/fazer da culinária da feira tal representação não alcança a tipificidade do mosaico nordestino, restringindo-se a reduzido cardápio, se comparado a expressividade culinária dos nove estados: mocotó, sarapatel, buchada, dobradinha, carne de sol, baião de dois, cabrito, rabada, galinha caipira, feijão tropeiro e farofa de carne seca (imagens dos cardápios 27, 28 e 29).

Segundo relato do maranhense, de 45 anos de idade, Jesuíno Araújo morador da Guariroba que chegou ao DF em 1988 frequenta a feira a vinte anos se recusa a se alimentar na feira "porque na feira não tem comida do Maranhão como o caranguejo e o sururu, só tem comida do Ceará". Jesuíno vai a feira por lazer e convivência. Relatou que é sempre bem tratado pelos feirantes e costuma comprar roupas e encontrar os amigos para tomar cerveja nas bancas de alimentação. Mostrou-se inconformado com os dizeres das fachadas das bancas em se denominarem nordestinas. Para o maranhense, se não oferece comida típica do Maranhão não deve ser considerada nordestina por estarem representado ali apenas alguns dos estados nordestinos.

A modernidade reformulou de modo criativo a vida metropolitana para apropriar-se da cidade o que ocasionou a dissolução da ordem social e cultural anteriores. 
Todo se condensa em la capacidade de dar forma a los linguajes de la modernidade y cultivar la ciudad según ritmos diferentes, marcándola com cadencias distintas. Es hablar los linguajes - linguísticos, literarios, culturales, religiosos, musicales- del dominador, del amo, pero siempre com uma diferencia. (CHAMBERS, 1995, p.44)

Nesse contexto, assim como os colonizados, pode-se dizer que os brasilienses reinscreveram e reorientaram a história da cidade quando reinventaram seus saberes-fazeres em diferentes feiras que palmilharam no território da cidade quebrando a lógica da ordenação do planejamento urbano pré-estabelecido ${ }^{13}$ do $\mathrm{DF}$, trazendo assim a sua região de origem para a capital federal.

Ninguém pode apagar o que se foi.

Os elementos tanto da linguagem quanto da identidade não podem ser negados ou anulados, mas podem ser ajustados. O sentido do ser e da identidade está em movimento. É formado e reformado constantemente.

A feira Permanente da Ceilândia foi criada como possibilidade de abastecimento e emprego/renda, na e para a Região Administrativa IX, em que está inserida, porém com o passar dos anos tanto a forma física/estética, quanto à forma socioeconômica, e, cultural foram adaptadas, remodeladas ou alteradas pelos seus fazedores na busca da reinvenção de suas tradições culturais.

A feira Permanente da Ceilândia é uma prova de que nem tudo foi cooptado por um modelo único de cultura globalizada, mas sim comporta o processo de hibridização das várias culturas regionais que formam a cultura nacional brasileira. Um resíduo que não se deixa suprimir movido por um ideal identitário de preservar de forma viva a vida de relações.

As feiras que resistem bravamente à invasão dos supermercados e shopping centers ainda persistem enquanto ponto de encontro, além de lugar do mercado. (CARLOS, 2007, p.82)

Nesse contexto identidade coletiva ressignifica-se nesse estudo pelas análises das evidencias como uma construção do imaginário onde o eu interior se identifica com determinado grupo e que ao conviver espontaneamente, ao compartilharem vida e/ou memórias formam ao longo do tempo, em conjunto, novos

\footnotetext{
13 O Plano Urbanístico de Brasília dividiu a cidade em eixos, setores e quadras que permanece até hoje. De zoneamento funcional com funções separadas da cidade, Brasília teve seu espaço racionalizado e setorizada: Setor Comercial, Setor Cultural, Setor Residencial, Setor Hoteleiro, Setor Hospitalar, Setor Gráfico, Setor de Postos e Espaços de Lazer. Todos identificados por siglas e numerados.
} 
sentidos e verdades para si e para o grupo.

A feira não se reduz a espaço de comércio. Como lugar de memória, de encontro ela se reinventa como um espaço também de preservação da cultura reinventando uma tradição que já não é ela mesma pela hibridização cultural. Assume a imagem de uma cultura que não se manteve estática, que assimilou estruturas de outras estruturas para formar sua estrutura híbrida.

Para Bourdieu (2011) se não existir o espaço estigmatizado pela privação de capital material e simbólico não existiria a necessidade de provar sua existência. No intuito de reverter essa estigmatização, de tempos atrás de que Ceilândia era violenta, pobre e marginalizada, o regionalismo nordestino é reivindicado na feira como resposta a essa estigmatização e ainda, para manter a coesão mesmo que simbólica do grupo que ali reside.

A gastronomia então passa a ser o elo entre o passado e o presente na feira. É o passado que se faz presente. O estar com para além de ser o que tenta ficar. A gastronomia busca se preservar como poder simbólico (Bourdieu, 2011). O símbolo que por mais que se globalize no processo do comércio, do mercantil não perde seu poder de reunir, de permitir a comunhão pela comensalidade. 


\section{CONSIDERAÇÕES FINAIS}

A feira Permanente da Ceilândia não depende do turismo para sobreviver como foi relatado pelos feirantes nas entrevistas, porém não deixa de ser uma experiência turística.

Desde a metade do século $\mathrm{XX}$, a valorização do turismo como atividade promotora da cultura e como veículo de conhecimento e integração de diversas sociedades e grupos, entre outros fatores, contribuíram para a consolidação do turismo como fenômeno social e atividade econômica preponderante. (MOLINA, 2011)

Para Moesch (2004) o turismo é uma inter-relação entre experiência subjetiva e o serviço consumido e acrescenta:

\footnotetext{
É muito mais que uma indústria de serviços, pois o fenômeno turístico é a composição de uma prática social com base cultural, com herança histórica, meio-ambiente diverso, cartografia natural, relações sociais de hospitalidade, troca de informações interculturais. (MOESCH, 2004, p. 15)
}

Nesse contexto, fenômeno é o objeto do conhecimento humano e a revelação do objeto em si à consciência do sujeito que a convoca. "Uma consciência doadora de sentido, encarnada em um corpo que pertence a uma história e a uma cultura; que, percebendo, sente; que, conhecendo, experimenta e que sentindo, conhece (NOBREGA, 2013, p. 28).

Transcender ao modelo industrial turístico e compreender essa atividade como fenômeno social é tratar o turismo como possibilidade de encontro com o novo, com o estranho sem pretender esquecer que possui forte apelo econômico.

Para Moesch (2002) o turismo é mais que um fenômeno de dimensões econômicas. Turismo é um complexo fenômeno sociocultural "de profundo valor simbólico aos sujeitos que o praticam" (p. 134).

[...] é uma prática social, ou melhor, um campo de práticas histórico-sociais, que pressupõe o deslocamento dos sujeitos, em tempos e espaços, produzidos de forma objetiva, possibilitador de afastamento simbólico do cotidiano, coberto de subjetividade, portanto explicitadores de uma nova estética diante a busca do prazer. (MOESCH, 2004, p. 465)

Para Molina (2011) o turismo como fenômeno social, deve ser pensado no plural (turismos) uma vez que existem diferentes modelos de turismo. 
Hay modelos de turismo que promueven el ejercicio de los derechos de la ciudadanía, y outro, como el industrial imitativo, que aíslan o acotan los derechos políticos y, especificamente la participación social em los procesos de toma de decisiones. (MOLINA, 2011, p. 33)

Os turismos de Molina (2011) possibilitam então que a experiência turística seja pensada em sua subjetividade para cada realidade conforme sua capacidade, especialidade e especificidade.

A partir dessa concepção teórica a feira da Ceilândia é pensada como possibilidade de experiência turística pois possibilita ao turista vivenciar a cidade de modo não habitual, não como representação de um cartão postal, onde seus fixos são institucionalizados e regulados como produtos turísticos.

O espaço da feira proporciona a possibilidade de experimentar as diferentes realidades do lugar. O turista ao vivenciar o cotidiano de Ceilândia pelas práticas do lugar de memória permite descobrir os diversos Distritos Federal, para além da Esplanada dos Ministérios, centro do poder nacional.

De modo geral Trigo (2010) entende experiência como:

[...] um fluxo de eventos particulares conhecidos apenas pelo sujeito que 0 vivencia, levando em consideração as problemáticas relações com outros eventos, como os acontecimentos do mundo externo ou fluxos de eventos similares pertencentes a outras pessoas. O fluxo forma a vida consciente do sujeito possuidor. (TRIGO, 2010, p.26)

A experiência propicia ao indivíduo criar a imagem do mundo ao seu modo, formando a forma de interação e relacionamentos com os outros e com si mesmo.

Segundo Trigo (2010) a experiência é essencial à socialização e a satisfação pessoal e possui diferentes graus de intensidade, duração e hierarquização da filosofia de valores principalmente morais. Por isso os eventos adquirem formatos de experiências diversas nos diferentes sujeitos. As experiências são subjetivas e relacionam-se com as memórias. Podem ser medíocres e banais ou mais intensas e profundas no sentido existencial:

"Nem todo serviço ou viagem é uma experiência que mereça ser repetida ou que marque significativamente a vida de alguém. A experiência tem a ver com a emoção, com o prazer, e não com o sentimentalismo e a acomodação estéril." (TRIGO, 2010, p. 31).

O turismo como experiência sugere que a experiência quebre a rotina possibilitando descobrir a si mesmo na escolha dos caminhos que complementam a 
existência como seres humanos. Romper com o superficialismo e buscar o que a paz para refletir sobre os prazeres da vida deixando o sujeito mais seguro da própria existência.

\begin{abstract}
Faz-se necessário, entretanto, recusar todos os modos de manipulação e telecomando, para permitir novos modos de sensibilidade humana, de relação com o outro que coincidam com aos desejos, ao gosto de viver, à vontade de conhecer o mundo, com a instauração de dispositivos capazes de desterritorializar, criando novas relações, sentidos e representações na busca da transversalidade entre os grupos humanos. (MOESCH, 2002, p. 15)
\end{abstract}

Em setembro de 2014 a pesquisadora apresentou a um turista alemão morador de Hamburgo/Alemanha a Feira da Ceilândia. Um homem de quarenta e poucos anos que já esteve em Brasília diversas vezes, pois sua ex-esposa era brasiliense. Durante o percurso de automóvel pela BR 070 ele confidenciou desconhecer que Taguatinga e Ceilândia fizessem parte de Brasília. Para ele a capital federal seria constituída apenas pelo avião (asas sul e norte) e pelos lagos sul e norte. Surpreendeu-se em saber que o DF era formado por 30 Regiões Administrativas o que conferiu maior curiosidade, segundo ele, em conhecer a feira da região de maior densidade urbana do DF. Ao avistarmos Ceilândia pela rodovia o alemão expressou simpatia pela localidade uma vez que a maioria das construções eram horizontais e explicou que para os alemães o amontoado de edificações verticais era bairro de classes menos favorecidas. Ao caminhar pela feira o alemão se espantou com a quantidade de réplicas de produtos importados que são comercializados na feira. Procurou, e encontrou, a cópia da camisa do time de futebol de sua cidade na Alemanha, Hamburgo, produzida pela marca Nike e disse que é difícil encontrar essa camisa até mesmo na loja da Nike de sua cidade.

Entre uma banca de roupa e outra, entre um chamado de feirante e outro, passamos pela banca de aves vivas e então ele expressou mais do que estranhamento àquele comércio. Pediu para se afastar desta banca dizendo que não estava acostumado com o odor.

Se interessou pela comida, conversou com algumas feirantes das bancas de alimentos perguntando o que serviam e por fim comprou queijo, tapioca e tomou água de coco. Pouco mais de duas horas depois se inicia o retorno à Asa Sul. No carro, o turista alemão testemunha que achou interessante a experiência de conhecer "uma 
Brasília que ele nem sabia que existia", e desculpou-se pela repulsa que sentiu à banca de aves vivas.

Atitudes e posturas sociais, culturais, estéticas e políticas são as condições para que os eventos tornem-se uma experiência marcante e significativa, caso contrário se cairá na mesmice da forma mecânica sem que seja promovido o entretenimento, a fuga, o prazer, o autoconhecimento, a aventura ou a descoberta. A banalidade, os aspectos triviais, estereotipados e convencionais devem ser superados para que a experiência nasça da riqueza pessoal do viajante em busca de momentos e lugares que enriqueçam sua história (TRIGO, 2010).

"Cada vez mais, a cidade será o resultado da rede de processos simbólicos, de comportamentos e culturas, que acontecem no seu interior" (GASTAL; MOESCH, 2007, p. 21). No contexto a cidade seria então um território de exercício da diversidade. A cidade ainda, deve ser vista ou vivida como um espaço de circulação de culturas, pessoas, ideias, ideologias, signos e significados.

Encontrar e conviver com o outro, diferente de si, resulta em espaços, culturais representativos da diversidade e para sobreviver, viver e conviver com esses locai é fundamental conhece-los.

Vivenciar semelhanças e diferenças são umas das razoes que leva o sujeito a praticar o turismo. Se, cada bairro da cidade é um espaço de identidade e identificação, então é possível fazer turismo sem sair de sua cidade.

"Turismo seria menos o percurso no espaço, para tornar-se um percurso por tempos-espaços, em especial culturais, diferentes daqueles a que se esteja habituado, com ênfase nas vivencias e experiências" (GASTAL; MOESCH, 2007, p. 37).

Uma parcela das experiências de lazer, da fruição do tempo, do descanso e do anti-cotiado acontece em lugares distintos da cidade de moradia do sujeito. Porém, o distanciamento da rotina e a aproximação do estranhamento podem ocorrer dentro da própria cidade, ao reorientar o olhar sobre os espaços da rotina. Nesse contexto pode-se ter uma experiência turística tanto na cidade de moradia quanto fora dela, basta para isso que o turista direcione seus olhares para os aspectos que são diferentes dos da vida comum. 
O espaço turístico tem que ser pedagógico, ou seja educativo, para um novo homem, para uma nova sociedade. Práticas de re-ligação, de comunhão, de encontro entre tribos, ou entre homem Terra são momentos fortuitos de um mundo prosaico, utilitarista, veloz. Trabalhar a desaceleração deste tempo turístico, não apenas para repor as forças para o tempo do, mas para animar, vibrar a vida, a alma. (MOESCH, 2004, p. 488)

Moesch define o turista que resgata a cultura de sua cidade, aprofundando os laços com ela passa a ser então o turista cidadão (GASTAL; MOESCH, 2007).

Para essa pesquisa o turista cidadão passa então a ser o sujeito que ao se expor ao estranhamento, distancia-se intencionalmente da rotina, movimentando-se e interagindo com sua cidade na produção de experiência significativas, reorientando seu olhar e desenvolvendo um relacionamento diferente com o local onde mora no seu tempo de lazer, através da utilização de fixos e fluxos com percepções diferentes da cotidiana.

Ou seja, o ato de ir à feira, ao parque, ao monumento. É caminhar pelo bairro. É ter uma vida mais sustentável. Por fim, sem a intenção de concluir, é apoderar-se da cidade com prazer nas horas de lazer por meio da experiência vivida. Conforme relato:

Cíntia Fernandes, mineira de João Pinheiro, chegou ao DF em 1997 e sempre morou na Samambaia. Há oito anos frequenta a feira e pelo menos três vezes por ano leva os parentes que vêm visita-la para fazer turismo e almoçar na feira. Relatou que leva os parentes para almoçar na feira por que cada um pode escolher o que quiser, rabada, sarapatel, buchada, galinhada e por ser um local informal, não engessado onde sente-se à vontade com a família (grifo da pesquisadora).

Historicamente feiras tenderiam a ser um processo dinâmico, itinerante, com atividade de montagem e desmontagem das barracas e relação de proximidade da feira com o local de moradia do consumidor, entretanto as feiras permanentes do DF alteram essa lógica sendo na verdade reproduções dos mercados encontrados em outras regiões do país e do exterior.

Nas práticas sociais, culturais e econômicas que deram e dão significado ou resinificam o espaço de memória da feira reconstrói-se o conceito de feiras e mercados onde são pontos de encontro e de convivência caracterizados pela informalidade e intimidade respeitosa, que apesar de sua função de comercialização de diversos tipos de produtos, como os hortifrutigranjeiros, cereais, grãos, laticínios, doces, pescados, alimentação, roupas e calçados, impõem na convivência valores 
simbólicos maiores do que de abastecimento ou consumo. Por ser o tipo de comercio varejista que mais se aproxima do consumidor, estas feiras e mercados são locais que possibilitam a experiência do viver e conviver, de se reconhecer na prática do viver.

$\mathrm{Na}$ manhã do dia 29 de março de 2015 o governador do Distrito Federal Rodrigo Rollemberg e sua esposa Márcia almoçaram na banca Kome in Pé. Sentaram-se nos bancos e comeram frango caipira, rabada, buchada e dobradinha. Naldo, feirante da banca, disse que a presença deles nas bancas de comida nordestina é comum. O governador e a primeira-dama por estarem nas redondezas, participaram da corrida de rua 10ª Corrida do Coração na QNN 27, optaram por ir até a feira pelo prazer de comer uma comida autentica, segundo eles. Rodrigo, que concedeu entrevista a pesquisadora na condição de cidadão e não governador confidenciou que gosta de buchada e que a feira o remete às lembranças de sua terra de origem, Piauí. Relatou ainda que gosta de feiras por serem espaços informais, sem censuras e tradicionais que imprimem imagem distinta do Distrito Federal além da Esplanada dos Ministérios.

Acrescentou: "Brasília é todo o Distrito Federal. Precisamos ver e mostrar o outro lado, a diversidade, o conjunto de manifestações culturais que muitos dos próprios brasilienses não conhecem. Precisamos fortalecer as feiras."

Para um significado do valor simbólico sobre a feira é preciso buscar as camadas mais profundas das atitudes socialmente construídas desse grupo identitário formado pelos processos migratórios, carecterístico de um território construído como o DF, para melhor compreender o caráter híbrido bem como sua autodenominação nordestina.

A metodologia utilizada na pesquisa alcançou o objetivo de analisar os processos de hospitalidade, comensalidade e convivência da feira Permanente da Ceilândia/DF como espaço de experiência turística no DF.

Os rituais de hospitalidade nas diferentes formas de atendimento aos visitantes da feira foram analisados pelas falas dos atores, feirantes e frequentadores, através das questões a respeito da inclusão de um prato de origem regional no cardápio das bancas sendo uma feira no DF e sobre a efetiva forma de atendimento. Sobre a forma de atendimento feirantes e frequentadores denunciam o modo informal, pessoal e divertido como características representativas do processo do bem receber. A escolha do cardápio se baseia em dois fatores: a) a comida da feira deve ser, historicamente, típica do Nordeste; b) os pratos são demandados pela clientela. Os 
fatores informam o empenho dos feirantes em agradar o paladar do cliente e em manter a tradição nordestina na comensalidade da feira.

Os processos de pertencimento propiciados aos frequentadores e feirantes com a feira é explicado pelas relações de pertencimento/identificação que os feirantes e visitantes têm com a feira. A frequência e a fidelidade às bancas evidenciam esse sentimento de pertença.

As práticas de identidade coletiva dos frequentadores da feira são descritas pelos sentimentos de pertencimento a cultural alimentar regional evidenciados nas falas dos visitantes que relatam buscar na feira uma culinária com sabor e qualidade representativos da cultura alimentar nordestina dificilmente encontrado em espaço diferente a feira. Ainda que dando sinais da globalização a culinária da feira Permanente da Ceilândia continua a proporcionar a ligação do centro do país ao sertão nordestino a esses sujeitos. As fachadas das bancas de alimentação que apelam para a caracterização nordestina fornecem indícios da reafirmação do "gueto" nordestino.

O papel da feira como lugar de memória que possibilita o sentimento de pertença, a comensalidade e a convivência na reconstrução das culturas que constituem o Distrito Federal foi analisado através dos processos de hospitalidade, comensalidade e convivência possibilitados pela feira com a inserção da pesquisadora no dia-a-dia da feira, aonde a etnografia conduziu a procura de fontes múltiplas de dados e evidencias para obter diferentes pontos de vista sobre o objeto pesquisado possibilitando compreender de forma ampla as relações que se dão naquele espaço. Para Geertz (1978) em estudos etnográficos os dados são construção do autor, ou seja, reconstrução das construções de outras pessoas sendo apenas a ponta do iceberg.

A comensalidade da feira Permanente da Ceilândia foi investigada a partir de questões simbólicas do lugar de memória que reflete o tipo de produção e/ou de transformação tradicional ocorrida nas preparações culinárias, ficando a origem geográfica e/ou gastronomia de terroir suprimida uma vez que a tecnologia e a globalização possibilitam a aquisição e/ou produção de matérias primas específicas de regiões distintas.

As formas de representação das culturas regionais foram identificadas pela gastronomia apresentada na feira da Ceilândia. Uma gastronomia com características do regionalismo nordestino com adaptações e substituições de outros estados 
brasileiros e influenciada pela globalização. Assim a prática gastronômica da feira Permanente da Ceilândia apresenta-se como uma cultura alimentar híbrida, representativa da multiculturalidade do Distrito Federal.

Nesse sentido a feira Permanente da Ceilândia apresentou-se nessa análise como espaço de encontro com o outro, de convivência e como possibilidade de experiência para além da possibilidade de consumo. A forma de experenciar o espaço, partilhar a vida e coexistir junto com o outro na feira como um local que não está presente na rotina do cidadão leva o sujeito a deslocar-se de sua vida cotidiana e experimentar o estranhamento em sua própria cidade, tornando-se um turista cidadão. Podendo ser uma forma de predispor a população a interagir, conhecendo e compreendendo a cidade de forma amplificada com suas teias de signos e significados.

Romper com o modo de pensamento de que a feira é um espaço de representação do Nordeste no DF, não é propor uma simples prática de substituição de rótulos, de nordestino por outro.

Romper com a construção social de um objeto pré-construído é compreender e refutar o jogo de poder que hoje não está fazendo tanto sentido para muitos atores. É rejeitar o domínio de quem não mais os representa com o entendimento (BOURDIEU, 2011), sobre as relações de forças simbólicas de que quem deu o poder ao dominador foram os próprios dominados. Porém, para que isso ocorra, os envolvidos nessa trama do poder simbólico terão que abrir mão das ações compensatórias oferecidas pelo meio e assim estarem verdadeiramente livres para se identificarem em suas próprias reinvenções.

$\mathrm{Na}$ forma atual, a feira Permanente da Ceilândia apresenta-se como um lugar de memória de manifestação regional nordestina. Como espaço de identificação de nordestinos que tiveram seus laços de pertencimento a uma identidade regional rompidos por uma ou duas vezes - a primeira ao trocarem suas terras natais por Brasília, e a segunda, por terem sido expulso da cidade que construíram e, assim, serem removidos para a Ceilândia.

O estudo respondeu ao problema de pesquisa de que as feiras desempenham um papel de ressignificação da identidade coletiva a partir da hospitalidade, comensalidade e convivência por serem lugares de memórias, libertatórios, informais, de festejo, que quebram o cotidiano, proporcionam as relações e possibilitam o encontro real do sujeito com o sujeito, com a sociedade e com a cidade. 
Se por um lado o problema de pesquisa dessa dissertação foi respondido, por outro lado outras possibilidades de análises apresentaram-se. Da feira emerge objetos de interesses diversos das mais variadas áreas, como da antropologia, sociologia, geografia, história, arquitetura, turismo e economia. É espaço público de memória, de trabalho, de relações pessoais aberta a todos e a todos os campos.

Sendo as feiras uma representação popular cômica, pública e tradicional, espaço que favorece o contato com a vida utópica, universal, libertadora, igualitária e abundante (BAKHTIN, 1993), o espaço ocupado pela feira Permanente da Ceilândia/DF possibilita a ressignificação da cultura onde a partir da gastronomia dos migrantes representadas na feira identifica-se uma expressão cultural híbrida do DF.

Assim, o trabalho feito no campo da etnografia possibilitou perceber a feira para além da objetividade. De espaço de comércio para lugar de hospitalidade e, portanto, propensa a acolher o turista/turista cidadão como forma de encontro. 


\section{REFERÊNCIAS}

ABDALA, Mônica Chaves. Receita de mineralidade: a cozinha e a construção da imagem do mineiro. 2. ed. Uberlândia: EDUFU, 2007.

ALMEIDA, Suzano. Feira da Ceilândia e de todos os nordestinos. Agência Brasília GDF, 2012. Disponível em: <http://www.df.gov.br/noticias/item/332-feira-deceil\%C3\%A2ndia-e-de-todos-os-nordestinos.html>. Acesso em: 27 jul. 2014.

ANGROSINO, Michael. Etnografia e observação participante. Porto Alegre: Artmed, 2009. (Col. Pesquisa Qualitativa)

ANUÁRIO DO DISTRITO FEDERAL. Ceilândia é reduto da nova classe média. Disponível em: <http://www.anuariododf.com.br/2012/regioes-administrativas/ra-ixceilandia/>. Acesso em: 02 jan. 2012.

ARAUJO, Wilma Maria Coelho. Da alimentação à gastronomia. Brasília: Editora Universidade de Brasília, 2005.

ATALA, Alex. Por uma gastronomia brasileira: para ler. São Paulo: BEI Comunicações, 2003.

AUGÉ, Marc. Não Lugares: introdução a uma antropologia da supermodernidade. 9. ed. Campinas: Papirus, 2012.

AYMARD, Maurice. Amizade e convivialidade. In.: CHARTIER, Roger [Org.] Histórias da vida privada: da renascença ao século das luzes. São Paulo: Companhia das Letras, 2009.

BACHELARD, Gaston. A poética do espaço. São Paulo: Martins Fontes, 1998.

BAKHTIN, Mikhail. A cultura popular na idade média e no renascimento: 0 contexto de François Rabelais. São Paulo: Hucitec, 1993.

BANCO NACIONAL DE DESENVOLVIMENTO. A segmentação do comércio varejista. Brasília: BNDES/Gerência Setorial de Comércio e Serviços, 2000.

Disponível

em:<http://www.bndes.gov.br/SiteBNDES/export/sites/default/bndes_pt/Galerias/Arq uivos/conhecimento/setorial/get4is12.pdf>. Acesso em: 10 nov. 2014.

BECHER, Clara; LOBÃO, Guilherme. Distrito Natureba. Revista Veja Brasília, ano 2, No 15, 9 de abril, 2014.

BERGER, Peter L.; LUCKMANN, Thomas. A construção social da realidade.

Petrópolis: Editora Vozes, 2006.

BERGSON, Henri. Matéria e memória. São Paulo: Martins Fontes, 1999. 
BOFF, Leonardo. Virtudes para um outro mundo possível, vol I: hospitalidade: direitos e deveres de todos. Petrópolis, RJ: Vozes, 2005.

BOFF, Leonardo. Virtudes para um outro mundo possível, vol II: convivência, respeito e tolerância. Petrópolis, RJ: Vozes, 2006.

BOURDIEU, Pierre. O poder simbólico. 15. ed. Rio de Janeiro: Bertrand Brasil, 2011.

BOUTAUD, Jean Jacques. Comensalidade: compartilhar a mesa. In.: MONTANDON, Alain [Org.]. O livro da hospitalidade: acolhida do estrangeiro na história e nas culturas. São Paulo: Editora Senac, 2011. p. 1213-1230.

BR SHOPPING. Disponível em: <http://www.brshoppings.com.br/shoppings/91shopping-conjunto-nacional.html>. Acesso em: 19 dez. 2014.

BRASÍLIA/DF. Decreto $\mathbf{n}^{\circ} \mathbf{1 9 . 0 4 0}$ de 19 de fevereiro de 1998. Diário Oficial do Distrito Federal. Disponível em:

<http://www.sedhab.df.gov.br/cpcoe/Biblioteca/Decreto_19040_98.pdf.>. Acesso em: 23 jul. 2014.

BURNS, Peter M. Turismo e antropologia: uma introdução. São Paulo: Chronos, 2002.

CABRAL, Ailim. Sede do governo do DF será transferido para Taguatinga no segundo semestre. Brasília, Correio Braziliense, 05 jun. 2014. Disponível em: <http://www.correiobraziliense.com.br/app/noticia/cidades/2014/06/05/interna_cidade sdf,431014/sede-do-governo-do-df-sera-transferida-para-taguatinga-no-segundosemestre.shtml>. Acesso em: 03 nov. 2014.

CÂMARA DOS DEPUTADOS. Construção do Palácio do Congresso Nacional. Disponível em: <http://www2.camara.leg.br/a-camara/conheca/camaradestaca/cinquenta-anos-da-camara-em-brasilia/palacio-do-congressonacional/imagens/construcao\%20-6.JPG/view>. Acesso em: 23 abr. 2015.

CANCLINI, Nestor García. Culturas híbridas. 4. ed. São Paulo: Edusp, 2013.

CARLOS, Ana Fani Alessandri. O lugar no/do mundo. São Paulo: Fflch, 2007.

CASCUDO, Luís da Câmara. História da alimentação no Brasil. 3. ed. São Paulo: Global, 2004.

CASTAN, Nicole. O público e o particular. In.: CHARTIER, Roger [Org.]. Histórias da vida privada: da renascença ao século das luzes. São Paulo: Companhia das Letras, 2009.

CATALDO, Beth; RAMOS, Graça [Org.]. Brasília aos 50 anos: que cidade é essa? Brasília: Tema Editora, 2010. 
CHAMBERS, lain. Migración, cultura, identidad. Buenos Aires: Amorrortu editores, 1995.

COMPANHIA DE PLANEJAMENTO DO DISTRITO FEDERAL - CODEPLAN. Pesquisa Distrital por Amostra de Domicílios: Ceilândia - PDAD 2013. Brasília, 2013. Disponível em:<http://www.codeplan.df.gov.br/images/CODEPLAN/PDF/ Pesquisas\%20Socioecon\%C3\%B4micas/PDAD/2013/Ceil\%C3\%A2ndia-PDAD\% 202013.pdf>. Acesso em: 23 jul. 2014.

COMPANHIA DO METROPOLITANO DO DISTRITO FEDERAL - METRÔ - DF. Linhas. Disponível em: < http://www.metro.df.gov.br/estacoes/linhas.html>. Acesso em: 04 nov. 2014.

CORREIO BRAZILIENSE. Nova sede do governo do Distrito Federal será inaugurada por Agnelo Queiroz. Disponível em:

$<$ http://www.correiobraziliense.com.br/app/noticia/cidades/2014/11/12/interna_cidade sdf,457129/nova-sede-do-governo-do-distrito-federal-sera-inaugurada-por-agneloqueiroz.shtml>. Acesso em: 10 nov. 2014.

COSTA, Leopoldo. História de criação de gado na Bahia. Disponível em: <http://stravaganzastravaganza.blogspot.com.br/2011/04/historia-da-criacao-degado-na-bahia.html>. Acesso em: 06 mai. 2014.

DAMATTA, Roberto. A Casa e a rua: espaço, cidadania, mulher e morte no Brasil. 5ª ed. Rio De Janeiro: Rocco, 1997.

DEMO, Pedro. Metodologia do conhecimento científico. São Paulo: Atlas, 2000.

DISTRITO FEDERAL. Agência Brasília. Novo centro administrativo do GDF tem 55\% das obras concluídas. Agência Brasília, 05 nov 2013 Disponível em: $<$ http://www.df.gov.br/noticias/item/10058-novo-centro-administrativo-do-gdf-tem-55das-obras-conclu\%C3\%ADdas.html>. Acesso em: 03 nov. 2014.

DISTRITO FEDERAL. Câmara Legislativa do Distrito Federal. Leis Distritais.

Disponível em: <http://www.cl.df.gov.br/web/guest/leis-distritais>. Acesso em: 17 out. 2014.

DISTRITO FEDERAL. Lei № 4.748, DE 2 DE FEVEREIRO DE 2012.

DISTRITO FEDERAL. Secretaria de Estado de Gestão do Território e Habitação SEGETH, 2015. Disponível em:

<http://www.sedhab.df.gov.br/projetos/Centro_Metropolitano/Centro_Metropolitano.ht m>. Acesso em: 27 abr. 2015.

DISTRITO FEDERAL. Secretaria de Estado do Meio Ambiente e Recursos Híbridos do Distrito Federal. Dados Ambientais das Regiões Administrativas. Disponível em: <http://www.semarh.df.gov.br/qualiar/mapa.html>. Acesso em: 11 mai. 2014.

DÓRIA. Carlos Alberto. Cozinheiro nacional. São Paulo: Senac, 2008. 
EMPRESA DE ASSISTÊNCIA TÉCNICA E EXTENSÃO RURAL DO DISTRITO FEDERAL. Governador entrega obras na Feira do Produtor de Ceilândia.

Disponível em: <http://www.emater.df.gov.br/index.php?option=com _content\&view=article\&id=1002:governador-entrega-obras-na-feira-do-produtor-deceilandia\&catid=47:noticias\&Itemid=125> . Acesso em: 14 jul. 2014.

FEIRA DE CARUARU. Noções gerais da feira: parque 18 de maio. Disponível em: $<$ http://feiradecaruaru.com/portal/nocoes-gerais-da-feira-parque-18-de-maio/>. Acesso em: 11 abr. 2014.

FEIRAS DO BRASIL. Calendário de feiras do Brasil 2014. Disponível em: <http://www.feirasdobrasil.com.br/produtos.asp>. Acesso em: 03 jun. 2014.

FERRETI, Mundicarmo. Feiras nordestinas: estudos e problemas. In.: FERRETI, Sergio [Org.] Reeducando o olhar: estudos sobre feiras e mercados. São Luis: Edições UFMA, 2000. (Cap. II) p. 35-66.

FIDELIS, Beatriz. Feira se consolidou como parte da cultura local. Faculdade de Comunicação. Universidade de Brasília. 28 nov 2013. Disponível em: $<$ http://campus.fac.unb.br/arquivo/cidade/item/3220-feira-central-daceil\%C3\%A2ndia>. Acesso em: 16 out 2014.

FREYRE, Gilberto. Açúcar: uma sociologia do doce, com receitas de bolos e doces do Nordeste do Brasil. São Paulo: Companhia das Letras, 1997.

FRUGOLI JUNIOR, Heitor. Sociabilidade urbana. Rio de Janeiro: Jorge Zahar Editora, 2007.

FUSTER, Luis Fernandez. Teoría y técnica del turismo. 2. ed. Madrid: Editora Nacional, 1971.

GASTAL, Susana; MOESCH, Marutschka. Turismo, políticas públicas e cidadania. São Paulo: Aleph, 2007. (Col. ABC do Turismo)

GEERTZ, Clifford. A interpretação das culturas. Rio de Janeiro: Zahar, 1978.

GOVERNO DO DISTRITO FEDERAL. Brasília capital dos brasileiros. Patrimônio da humanidade. Disponível em:

$<$ http://www.brasiliapatrimoniodahumanidade.df.gov.br/index.php?option=com_conte nt\&view=article\&id=7\&ltemid=9>. Acesso em: 09 jan. 2014.

GOVERNO DO DISTRITO FEDERAL. Feiras do GDF receberão investimento.

Disponível em: <http://www.vice.df.gov.br/noticias/item/2030-feiras-do-dfreceber\%C3\%A3o-investimentos.html>. Acesso em: 30 dez. 2012.

GOVERNO DO DISTRITO FEDERAL. Feiras: CLDF aprova regulamentação.

Dezembro, 2011. Disponível em: <http://www.df.gov.br/noticias/item/1110-feiras-cldfaprova-regulamenta\%C3\%A7\%C3\%A3o.html>. Acesso em: 12 mai. 2014. 
GOVERNO DO DISTRITO FEDERAL. Portal o governo de Brasília. Disponível em: $<$ http://www.df.gov.br/> . Acesso em: 27 abr. 2015.

GRASSI, Marie-Clarie. Hospitalidade: transpor a soleira. In.: MONTANDON, Alain [Org.] O livro da hospitalidade: acolhida do estrangeiro na história e nas culturas. São Paulo: Editora Senac, 2011.

GRINOVER, Lucio. A hospitalidade, a cidade e o turismo. São Paulo: Aleph, 2007. (Série Turismo).

GROS, Frédéric. Caminhar, uma filosofia. São Paulo: É realizações, 2010.

GUGLIELMO, Roberto de; FITTIPALDI, Ciça. Feiras e mercados brasileiros. São Paulo: Editora Fólio, 2005.

GUIMARÃES, Olmária. O Papel das feiras-livre no abastecimento da cidade de São Paulo. In.: Série Teses e Monografias $n^{\circ} 2$. São Paulo: Universidade de São Paulo, 1969.

HALL, Stuart. A identidade cultural na pós modernidade. 11. ed. Rio de Janeiro: DP\&A, 2011.

INSTITUTO BRASILEIRO DE GEOGRAFIA E ESTATÍSTICA - IBGE. Contagem da população 1996. Rio de Janeiro: IBGE, 1997. v. 1.

INSTITUTO BRASILEIRO DE GEOGRAFIA E ESTATÍSTICA - IBGE. Senso Demográfico 2010. Disponível em:

<http://www.ibge.gov.br/home/estatistica/populacao/censo2010/default.shtm>. Acesso em: 12 mai. 2014.

INSTITUTO DO PATRIMONIO HISTÓRICO E ARTÍSTICO NACIONAL. Bens registrados. Disponível em:

<http://portal.jphan.gov.br/portal/montarPaginaSecao.do?id=17743\&sigla=Institucion al\&retorno=paginalnstitucional>. Acesso em: 14 abr. 2014.

INSTITUTO DO PATRIMONIO HISTÓRICO E ARTÍSTICO NACIONAL. Certidão: ofício das baianas de acarajé. Brasília, 2004. Disponível em:

$<$ http://portal.iphan.gov.br/portal/montarDetalheConteudo.do?id=17750\&sigla=Institu cional\&retorno=detalhelnstitucional $>$. Acesso em: 15 abr. 2014.

INVENTÁRIO NACIONAL DE REFERÊNCIAS CULTURAIS. Manual de aplicação. Brasília: Instituto do Patrimônio Histórico e Artístico Nacional, 2000.

JESUS, Vinicius Lino Rodrigues. Do centro à zona sul: análise dos espaços de consumo e lazer em Uberlândia. In.: Tese de Doutorado - Universidade Federal de Uberlândia, Programa de Pós-Graduação em Geografia, 2014.

JORNAL DE BRASÍLIA. Shopping na vizinhança. Disponível em: $<$ http://www.jornaldebrasilia.com.br/noticias/cidades/511806/shopping-navizinhanca/>. Acesso em: 19 dez. 2014. 
KOTLER, Philip. Administração de marketing: análise, planejamento, implementação e controle. 5. ed. São Paulo: Atlas, 1998.

KRIPPENDORF, Jost. Sociologia do turismo: para uma nova compreensão do lazer e das viagens. 3. ed. São Paulo: Aleph, 2003.

LARAIA. Roque de Barros. Cultura: um conceito antropológico. 24. ed. Rio de Janeiro: Zahar, 2009.

LEAL, Angela Barros. Mercados de ferro do Brasil. Brasília: Instituto Terceiro Setor, 2011.

LEAL, Maria Leonor de Macedo Soares. A história da gastronomia. Rio de Janeiro: Editora Senac, 1998.

LUIZ, Edson Béu. Os filhos dos candangos: exclusão e identidades. In.: Dissertação de Mestrado. Instituto de Ciências Humanas. Programa de PósGraduação em História. Universidade de Brasília, Brasília, 2007.

MADEIRA, Angélica; VELOSO, Mariza. Leituras brasileiras: itinerário no pensamento social e na literatura. São Paulo: Paz e Terra: 1999.

MAGALHÃESS FILHO, Francisco de B. B. de. História econômica. $5^{\text {a }}$ ed. São Paulo: Editora Sugestões Literárias S/A, 1978.

MANHÃES, Paulo. Brasília completa 50 anos. 30 mar. 2010. Disponível em:<http://noticias.uol.com.br/album/100415brasilia50_album.jhtm\#fotoNav=40>. Acesso em: 23 abr. 2015.

MARCELLINO, Nelson Carvalho. Estudo do lazer: uma introdução. 3. ed. Campinas: Autores Associados, 2002. (Col. Educação Física e Esportes)

MARTINS, Antonio Egydio. São Paulo antigo, 1554 - 1910. São Paulo: Paz e Terra, 2003.

MARTINS, Gilberto de Andrade. Estudo de caso: uma estratégia de pesquisa. São Paulo: Atlas, 2007.

MASCARENHAS, G. Ordenando o espaço público: a criação das feiras livres na cidade do Rio de Janeiro. Revista electrónica de geografía y ciencias sociales. Barcelona: Universidad de Barcelona, 1 de agosto de 2005, vol. IX, núm. 194. Disponível em: <http://www.ub.es/geocrit/sn/sn-194-62.htm>. Acesso em: 15 mai. 2014.

MINISTÉRIO DO DESENVOLVIMENTO, INDÚSTRIA E COMÉRCIO EXTERIOR. Principais estatísticas do mercado doméstico. Disponível em: $<$ http://www.desenvolvimento.gov.br//sitio/interna/interna. $p h p ? a r e a=4 \& m e n u=4459>$. Acesso em: 10 nov. 2014. 
MOESCH, Marutschka Martini. A produção do saber turístico. São Paulo: Contexto, 2002.

MOESCH, Marutschka Martini. Epistemologia Social do Turismo. In.: Tese de Doutorado - Universidade de São Paulo. Programa de pós-Graduação em Relações Públicas, Propaganda e Turismo da Escola de Comunicação e Arte. São Paulo: 2004.

MOESCH, Marutschka Martini. Viver a hospitalidade. In.: Texto apresentado $22^{\circ}$ ENAREL, Atibaia-SP, 2010.

MOLINA, Sergio. Turismo creativo: el fin de la competitividade. Chile: Escritores, 2011.

MONTANARI, Massimo. Comida como cultura. São Paulo: Editora Senac, 2008.

MOTT, Luis R. B. Subsídios à história do pequeno comércio no Brasil. In.: Revista de História, USP. № 105, 1976. Disponível em:

<http://revhistoria.usp.br/index.php/br/edicoes/163-rh-105>. Acesso em: 01 abr. 2014.

MOTT, Luis. Feira e mercado: pistas para pesquisa de campo. In: FERRETTI, Sergio [Org.] Reeducando o Olhar: estudos sobre feiras e mercados. São Luís: Edições UFMA, 2000. (Cap. I) p. 13-34.

MÜLLER, Silvana Graudenz. Patrimônio cultural gastronômico: identificação e disseminação dos saberes e fazeres tradicionais. In.: Tese de Doutorado Universidade Federal de Santa Catarina. Programa de Pós-Graduação em Engenharia e Gestão do Conhecimento. Florianópolis, 2012.

NIKODIMOV, Marie-Gaille. Etnografia: observar, compreender, participar. In MONTANDON, Alain [Org.] O livro da hospitalidade: acolhida do estrangeiro na história e nas culturas. São Paulo: Editora Senac, 2011. p. 83-96.

NOBRAGA, Lara Santina Santos da. O desvelar do centro histórico de João Pessoa pelo turista/flâneur. 2013. In.: Dissertação de Mestrado - Universidade de Brasília, Centro de Excelência em Turismo, Mestrado Profissional em Turismo, 2013.

OLIVEIRA, Lucia Lippi. Cultura é patrimônio: um guia. Rio de Janeiro, FGV: 2008.

OLIVEN, Ruben George. A antropologia de grupos urbanos. 6. ed. Petrópolis, RJ: Vozes, 2007.

PIERRE, M. C. Q M. Um recorte em territórios artificializados: agricultura familiar e comercialização na feira dos goianos - Gama/DF. In.: Dissertação de Mestrado Universidade de Brasília - Faculdade de Agronomia e Medicina Veterinária, Brasília, 2010.

PIRES, Mário Jorge. Raízes do turismo no Brasil. Barueri: Manole, 2001. 
POLLAK, Michael. Memória, esquecimento, silêncio. In.: Estudos Históricos, Rio de Janeiro, v. 2, n. 3, 1989, p 3-15.

POLLAN, Michael. O dilema do onívoro. Rio de Janeiro: Intrínseca, 2007.

PREFEITURA DE SÃO PAULO. História das feiras livres: as feiras livres fazendo parte da história de São Paulo. Disponível em:

<http://www.prefeitura.sp.gov.br/cidade/secretarias/subprefeituras/abastecimento/feir as_livres/index.php? $\mathrm{p}=6637$ >. Acesso em: 14 abr. 2014.

PREFEITURA DO RIO DE JANEIRO. Feiras livres. Disponível em: <http://www.rio.j.gov.br/web/seop/exibeconteudo?id=2816069>. Acesso em: 23 jul. 2014.

QUEIRÓS Adirley [Direção]. A cidade é uma só. Documentário [Gênero]. Brasília: Vitrine Filmes, 2012. (Filme -79 min.)

RAMASSOTE, Rodrigo Martins; BESSONI, Giorge. Patrimônio imaterial: ações e projetos da superintendência do IPHAN no DF. In.: Arquitextos, São Paulo, ano 10, n. 120 Vitruvius, maio 2010. Disponível em:

<http://vitruvius.com.br/revistas/read/arquitextos/10.120/3428>. Acesso em: 30 jul. 2014.

RAU, Virgínia. Feiras medievais portuguesas: subsídio para o seu estudo. Lisboa: Editora Presença, 1982.

SANTOS, Milton. A natureza do espaço: técnica e tempo - razão e emoção. 3. ed., São Paulo: HUCITEC, 1999.

SANTOS, Milton. O espaço dividido: os dois circuitos da economia urbana dos países subdesenvolvidos. São Paulo: Editora da Universidade de São Paulo, 2008.

SATO, Leny. Feira livre: organização, trabalho e sociedade. São Paulo: Editora da Universidade de São Paulo, 2012.

SERRANO, Agnes da França. A implantação do centro metropolitano de Brasília - Distrito Federal e as transformações do espaço interurbano. In.: Dissertação de Mestrado - Universidade de Brasília. Instituto de Ciências Humanas. Departamento de Geografia, 2014.

SILVA, Aliane. Cruzeiro, local de muitas histórias. Agência Brasília: Brasília, 2011. Disponível em: <http://www.df.gov.br/noticias/item/1056-cruzeiro-local-de-muitashist\%C3\%B3rias.html>. Acesso em: 15 jul. 2014.

SILVA, Ernesto. História de Brasília: um sonho, uma esperança, uma realidade. 2. ed. Brasília: Senado Federal/Centro Gráfico, 1985.

SILVANO, Filomena. Antropologia dos espaços. Lisboa: Assírio \& Alvim, 2010. 
Federal e Regiões Administrativas. Brasília, 2004.

SUBSECRETARIA DE ESTATÍSTICA E INFORMAÇÕES - SEPLAN. Pesquisa distrital por amostra de domicílios - Distrito Federal - 2011. Brasília, 2011. Disponível em: <http://www.codeplan.df.gov.br/component/content/article/261 pesquisas-socioeconomicas/257-pdad.html. . . Acesso em: 13 abr. 2015.

SUBSECRETARIA DE ESTATíSTICA E INFORMAÇÕES - SEPLAN. Pesquisa distrital por amostragem de domicílios - Distrito Federal - PDAD/DF 2013. Disponível em:

<http://www.codeplan.df.gov.br/images/CODEPLAN/PDF/pesquisa_socioeconomica/ pdad/2013/Pesquisa\%20PDAD-DF\%202013.pdf >. Acesso em: 13 abr. 2015.

TORO, Jose Bernardo. A construção do público: cidadania, democracia e participação. Rio de Janeiro: Senac Rio, 2005.

TRIGO, Luiz Gonzaga Godoi. A viagem como experiência significativa. In.: PANOSSO NETO, Alexandre; GAETA, Cecília. Turismo de experiência. São Paulo: Senac, 2010.

VASCONCELOS, Adirson. As cidades satélites de Brasília. Brasília: Senado Federal/Centro Gráfico, 1988.

VASCONCELOS, Adirson. Brasília: o homem e a cidade. Brasília: Editora União, 1960.

VASCONCELOS, Adirson. Os pioneiros da construção de Brasília. 2ovol. Brasília: [s.n.], 1992. 


\section{APÊNDICE I}

\section{QUESTÕES ORIENTATIVAS PARA ENTREVISTA \\ FEIRANTE FEIRA DA CEILÂNDIA}

Número da entrevista:

Data:

Hora: Banca:

Nome:

Sexo: ( ) Masculino ( ) Feminino

Estado de origem:

Estado de Origem do pai:

Ano de chegada no DF:
Idade:

Município de origem:

Estado de origem da mãe:

Onde morou:

Região Administrativa em que mora hoje:

Há quanto tempo trabalha como feirante:

Há quanto tempo trabalha na Feira da Ceilândia:

Quantas pessoas trabalham na Banca:

Quantas pessoas da sua família trabalham na Banca:

Renda familiar (em salário mínimo):

Há quantos anos a banca pertence a sua família:

Como é definido o cardápio da Banca:

O que leva a inclusão de um prato de origem regional no cardápio:

Existe algum processo de atendimento que identifique as características de origem nordestina:

Qual o prato que mais vende:

Com quem aprendeu a preparar esse prato:

Como é feito esse prato:

Algum outro prato importante/tradicional da banca:

Os clientes são fiéis, assíduos:

Qual a relação com os clientes:

Atende turistas com que frequência?

( ) Diariamente ( ) Semanalmente ( ) Mensalmente ( ) Nunca

Faturamento Bruto mensal da banca:

Que outro atrativo a feira oferece ao público?

( ) Música ( ) Apresentação Cultural ( ) Outros

Se outros, qual?

Observações: 


\section{APÊNDICE II \\ QUESTÕES ORIENTATIVAS PARA ENTREVISTA \\ FREQUENTADORES FEIRA DA CEILÂNDIA}

Número da entrevista:

Data:

Hora:

Local dentro da feira onde o frequentador foi abordado para entrevista:

Nome:

Sexo: ( ) Masculino ( ) Feminino

Estado de origem:

Estado de Origem do pai:

Ano de chegada no DF:

Região Administrativa em que mora hoje:

Renda familiar (em salário mínimo):

Com que frequência vai à feira da Ceilândia:

( ) Diariamente ( ) Semanalmente ( ) Mensalmente ( ) Nunca

Quais os dias da semana frequenta a feira da Ceilândia?
( ) Segunda-feira
( ) Terça-feira
( ) Quarta-feira
( ) Domingo
( )Sexta-feira ( )Sábado
( ) Quinta-feira

Idade: Município de origem:

Estado de origem da mãe:

Onde morou quando chegou no DF:

Há quanto tempo frequenta a feira da Ceilândia?

Frequenta outras feiras? ( ) $\operatorname{Sim}($ ) Não

Se sim, quais?

Quais motivos lhe trazem a feira da Ceilândia?

O que vai fazer na feira?
( ) Comercial
( ) Convivência
( ) Lazer
( ) Pertencimento/memória
( ) Outros
O que?

Quanto tempo fica na feira (em horas)?

O que compra na feira?

Por que se alimenta na feira?

Qual prato/banca de maior preferência?
Por que?
( ) Preço
( )Comodidade
( ) Sabor
( )Outros
( ) Qualidade

Se outros, o que?

O que come na feira que não come em outro lugar no DF?

Se não comer o prato apontado na questão anterior na feira onde comeria?

Se esse prato for ofertado na praça de alimentação de um shopping center, você deixaria de ir à feira comer esse prato?
( ) $\operatorname{Sim}($ ) Não
Por que?

Como é tratado na feira pelos feirantes?

Observações: 


\section{APÊNDICE III}

Tabela: Leis do Distrito Federal sobre Feiras

\begin{tabular}{|c|c|}
\hline Lei & \\
\hline$\underline{5053 / 2013}$ & $\begin{array}{l}\text { Inclui, no calendário oficial de eventos do Distrito } \text { Federal, } \\
\text { a Feira Nacional de Flores, Decoração e Plantas Ornamentais - FestFlor }\end{array}$ \\
\hline$\underline{5046 / 2013}$ & $\begin{array}{l}\text { Instalação de banheiros químicos ou definitivos em feiras livres no âmbito } \\
\text { do Distrito Federal. }\end{array}$ \\
\hline$\underline{4988 / 2012}$ & Obrigatoriedade de balança pública em feiras livres do Distrito Fed \\
\hline$\underline{4934 / 2012}$ & Instalação e o funcionamento de feiras it \\
\hline$\underline{4919 / 2012}$ & $\begin{array}{l}\text { Obriga os vendedores e expositores de feiras e eventos realizados em } \\
\text { praças ou logradouros públicos a usar coletores de lixo ao lado de suas } \\
\text { barracas ou estandes. }\end{array}$ \\
\hline $4798 / 2012$ & ão da Feira Cultural no Distrito Federal. \\
\hline$\underline{4791 / 2012}$ & $\begin{array}{l}\text { Institui a reserva de espaço físico nas feiras realizadas no Distrito Federal } \\
\text { para produtos artesanais locais. }\end{array}$ \\
\hline$\underline{4748 / 2012}$ & $\begin{array}{l}\text { Regularização, organização e funcionamento das feiras livres e } \\
\text { permanentes. }\end{array}$ \\
\hline$\underline{4634 / 2011}$ & $\begin{array}{l}\text { Alimentos, doação, programa de governo, normas. Alimentos, distribuição. } \\
\text { Assistência à família. Nutrição. Supermercado, restaurante, feira. }\end{array}$ \\
\hline$\underline{4420 / 2009}$ & $\begin{array}{l}\text { Concede remissão de débitos relativos à ocupação de área pública por } \\
\text { permissionários de feiras, trailers, quiosques e similares, na forma que } \\
\text { especifica. }\end{array}$ \\
\hline$\underline{4382 / 2009}$ & $\begin{array}{l}\text { Inclui no calendário de eventos oficiais do Distrito Federal a Feira de } \\
\text { Agronegócio - Agrobrasília. }\end{array}$ \\
\hline$\underline{3778 / 2006}$ & Inclui a Feira de Saúde no Calendário Oficial de Eventos do DF \\
\hline$\underline{3730 / 2005}$ & $\begin{array}{l}\text { Redução de base de cálculo do Imposto sobre Serviços de Qualquer } \\
\text { Natureza - ISS incidente na prestação de serviços que especifica. }\end{array}$ \\
\hline$\underline{3622 / 2005}$ & $\begin{array}{l}\text { Inclui no calendário oficial de eventos do DF a Expotchê - Feira de } \\
\text { Produtos Gaúchos do DF. }\end{array}$ \\
\hline$\underline{3571 / 2005}$ & $\begin{array}{l}\text { Destina área nas feiras livres e permanentes das Regiões Administrativas } \\
\text { para a atividade mercantil de produtos artesanais e dá outras } \\
\text { providências. }\end{array}$ \\
\hline$\underline{3546 / 2005}$ & minação da Feira do Produtor de Sobradinho. \\
\hline $3536 / 2005$ & $\begin{array}{l}\text { Inclui no calendário oficial do DF a Feira de Amostra do Comércio e } \\
\text { Indústria de Taguatinga - FACITA. }\end{array}$ \\
\hline $3430 / 2004$ & $\begin{array}{l}\text { Destina espaço nas feiras permanentes do DF para manifestação cultural } \\
\text { e artística. }\end{array}$ \\
\hline$\underline{3375 / 2004}$ & $\begin{array}{l}\text { Inclui a Feira de Amostras do Gama - FAGAMA no calendário oficial de } \\
\text { eventos do Distrito Federal. }\end{array}$ \\
\hline$\underline{3308 / 2004}$ & $\begin{array}{l}\text { Permite o funcionamento noturno, nos finais de semana, da Feira da Torre } \\
\text { de TV, da Região Administrativa de Brasília - RA I. }\end{array}$ \\
\hline$\underline{3082 / 2002}$ & $\begin{array}{l}\text { Inclui como permissionárias do } \\
\text { Desenvolvimento Economico Integrado e Sustentado do Distrito Federal - } \\
\text { PRÓ-DF a Feira Permanente, Feira do Produtor Colónia Agrícola Vicente } \\
\text { Pires e Feirados Importados }\end{array}$ \\
\hline$\underline{3068 / 2002}$ & $\begin{array}{l}\text { Cria em cada Região Administrativa do Distrito Federal o Feirão dos } \\
\text { Pequenos Empresários Prestadores de Serviço para congregar } \\
\text { profissionais habilitados na prestação de serviços de caráter técnico. }\end{array}$ \\
\hline$\underline{2981 / 2002}$ & Altera a Lei $n^{0} 2.815$, de 6 de nove \\
\hline$\underline{2906 / 2002}$ & $\begin{array}{l}\text { Inclui a Feira do Livro de Brasília no calendário oficial de eventos do } \\
\text { Poder Executivo. }\end{array}$ \\
\hline$\underline{2815 / 2001}$ & Instalação e o funcionamento das feiras itinerantes no âmbito do DF. \\
\hline$\underline{2810 / 2001}$ & $\begin{array}{l}\text { Dá tratamento preferencial a idosos, gestantes, deficientes físicos e } \\
\text { portadores de necessidades especiais nos locais que menciona, no Distrito } \\
\text { Federal. }\end{array}$ \\
\hline
\end{tabular}




\begin{tabular}{|c|c|}
\hline $02 / 2001$ & ncionamento do comércio aos domingos e fer \\
\hline $696 / 2001$ & tric na \\
\hline$\underline{2571 / 2000}$ & $\begin{array}{l}\text { Altera a Lei no } 1.376 \text {, de } 17 \text { de janeiro de } 1997, \text { que Transforma } \\
\text { a feira livre do Riacho Fundo em feira permanente. }\end{array}$ \\
\hline$\underline{2559 / 2000}$ & $\begin{array}{l}\text { Reserva, nas feiras livres e feiras permanentes DF, boxes para } \\
\text { instituições que deem assistência a portadores de necessidades especiais } \\
\text { tipo mentais e sensoriais, com total isenção de taxas. }\end{array}$ \\
\hline$\underline{229}$ & $\begin{array}{l}\text { Altera a Lei no } 1.828, \text { de } 13 \text { de janeiro de } 1998 \text {, que Disciplina a } \\
\text { organização e o funcionamento das feiras livres e permanentes no DF. }\end{array}$ \\
\hline 203 & $\begin{array}{l}\text { Cria o Parque de Exposições e Feiras Agropecuárias de São Sebastião, na } \\
\text { Região Administrativa de São Sebastião - RA XIV. }\end{array}$ \\
\hline$\underline{201}$ & $\begin{array}{l}\text { Funcionamento da feira localizada na Estação Rodoviária de Brasília, na } \\
\text { Região Administrativa do Plano Piloto - RA I. }\end{array}$ \\
\hline 998 & $\begin{array}{l}\text { Altera a Lei no } 1.442 \text {, de } 22 \text { de maio de 1997, que Transforma a Feira Livre } \\
\text { de São Sebastião em Feira Permanente e dá outras providências. }\end{array}$ \\
\hline 1937 & $\begin{array}{l}\text { Destina área para a feira permanente da Região Administrativa do Recanto } \\
\text { das Emas - RA XV. }\end{array}$ \\
\hline 998 & $\begin{array}{l}\text { Dispõe sobre a área reservada ao Centro Comunitário da Colônia Agrícola } \\
\text { Vicente Pires e dá outras providências. }\end{array}$ \\
\hline$\underline{1874}$ & $\begin{array}{l}\text { Altera a Lei no } 235 \text {, de } 15 \text { de janeiro de } 1992 \text {, que Regulamenta } 0 \\
\text { funcionamento das feiras livres e permanentes no DF e dá outras } \\
\text { providencias. }\end{array}$ \\
\hline$\underline{1828}$ & $\begin{array}{l}\text { Disciplina a organização e }{ }^{\circ} \text { funcionamento } \\
\text { permanentes no Distrito Federal. }\end{array}$ \\
\hline 1822 & $\begin{array}{l}\text { Denomina Praça Padre Cícero o espaço contíguo à Feira de } \\
\text { Hortifrutigranjeiros, situado em frente às Quadras } 3 \text { e } 4 \text { do Setor } \\
\text { Residencial Leste, na Região Administrativa de Planaltina - RA VI. }\end{array}$ \\
\hline 173 & $\begin{array}{l}\text { Institui a Feira Livre dos Goianos na Região Administrativa do Gama - RA } \\
\text { II. }\end{array}$ \\
\hline$\underline{15 \varepsilon}$ & $\begin{array}{l}\text { Dá nova redação ao art. }{ }^{\circ} \text { da Lei no } 1.328 \text {, de } 26 \text { de dezembro de 1996, } \\
\text { que Autoriza o Governo do Distrito Federal a reservar a área que } \\
\text { especifica para uso dos artesãos do Distrito Federal e dá outras } \\
\text { providências. }\end{array}$ \\
\hline$\underline{1488}$ & Dispõe sobre a transferência da feira livre da Candangolândia. \\
\hline $1442 / 1997$ & re de São Sebastião em feira permanente. \\
\hline$\underline{1384 / 1997}$ & $\begin{array}{l}\text { Fixa prazo para regulamentação da Lei no } 610 \text {, de } 6 \text { de dezembro de 1993, } \\
\text { que dispõe sobre a criação e fixação da Feira de Materiais Novos e Usados } \\
\text { na Ceilândia. }\end{array}$ \\
\hline$\underline{1376 / 1997}$ & rma a feira livre do Riacho Fundo em feira permane \\
\hline $1345 / 1996$ & tui a Feira Permanente da Região Administrativa III - Taguatinga. \\
\hline $1328 / 1996$ & $\begin{array}{l}\text { Autoriza o Governo do Distrito Federal a reservar a área que especifica } \\
\text { para uso dos artesãos do Distrito Federal e dá outras providências. }\end{array}$ \\
\hline 1292 & $\begin{array}{l}\text { Destina área na QN } 510 \text { da Região Administrativa de Samambaia para } \\
\text { construção de feira permanente e dá outras providências. }\end{array}$ \\
\hline 126 & $\begin{array}{l}\text { Dispõe sobre o uso e a preservação do Parque Recreativo Rogério Pithon } \\
\text { Farias. }\end{array}$ \\
\hline$\underline{124}$ & $\begin{array}{l}\text { Destina área na Região Administrativa de Samambaia para a construção } \\
\text { de feira permanente. }\end{array}$ \\
\hline $1242 / 1996$ & a a Feira Permanente do Setor M Norte de Taguatinga - RA III. \\
\hline $1154 / 1996$ & $\begin{array}{l}\text { Autoriza o Poder Executivo a criar Postos Volantes de Informação ao } \\
\text { Cidadão Consumidor junto às feiras e espaços de comercializaão de } \\
\text { veículos e dá outras providências. }\end{array}$ \\
\hline$\underline{115}$ & $\begin{array}{l}\text { Dispõe sofre a Feira Permanente da Região Administrativa do Recanto das } \\
\text { Emas - RA XV. }\end{array}$ \\
\hline$\underline{1109 / 1996}$ & titui a Feira Livre da Região Administrativa de Brasília - RA I. \\
\hline $1049 / 1996$ & $\begin{array}{l}\text { Autoriza o Governo do Distrito Federal a construir feira permanente na } \\
\text { Região Administrativa de Santa Maria - RA XIII e dá outras providências. }\end{array}$ \\
\hline$\underline{978 / 1995}$ & $\mathrm{ra}$ \\
\hline
\end{tabular}




\begin{tabular}{|c|c|}
\hline & onstrução da feira de múltiplas funções e dá outras provid \\
\hline $972 / 1995$ & Iimpeza pública e dá outras providências. \\
\hline$\underline{798 / 1994}$ & $\begin{array}{l}\text { Dá nova redação ao art. 1ำ e seu parágrafo único da Lei no } 608 \text {, de } 2 \text { de } \\
\text { dezembro de } 1993 \text {. }\end{array}$ \\
\hline $760 / 1994$ & $\begin{array}{l}\text { Acrescenta parágrafo ao art. } 10 \text { da Lei no } 235 \text {, de } 15 \text { de janeiro de 1992, } \\
\text { modificada pela Lei no } 259 \text {, de } 5 \text { de maio de } 1992 \text {, e pela Lei no } 321 \text {, de } \\
24 \text { de setembro de } 1992 \text {, e dá outras providências. }\end{array}$ \\
\hline$\underline{741 / 1994}$ & $\begin{array}{l}\text { Autoriza a instalação e funcionamento } \text { de feiras livres móveis e } \\
\text { temporárias na área que especifica. }\end{array}$ \\
\hline$\underline{610 / 1993}$ & $\begin{array}{l}\text { Dispõe sobre a criação e fixação da Feira de Materiais Novos e Usados na } \\
\text { Ceilândia e dá outras providências. }\end{array}$ \\
\hline$\underline{608 / 1993}$ & $\begin{array}{l}\text { Autoriza o Governo do Distrito Federal a ampliar a Feira Permanente do } \\
\text { Guará, na Região Administrativa X - RA X, e dá outras providências. }\end{array}$ \\
\hline$\underline{530 / 1993}$ & $\begin{array}{l}\text { Autoriza o Governo do Distrito Federal a construir uma feira do atacado } \\
\text { de produtos hortigranjeiros em Samambaia e dá outras providências. }\end{array}$ \\
\hline$\underline{500 / 1993}$ & $\begin{array}{l}\text { Torna obrigatória a colocação de balanças à disposição do consumidor nos } \\
\text { estabelecimentos que especifica e dá outras providências. }\end{array}$ \\
\hline$\underline{321 / 1992}$ & $\begin{array}{l}\text { Acrescenta parágrafo ao art. } 10 \text { da Lei no } 235 \text {, de } 15 \text { de janeiro de } 1992, \\
\text { modificada pela Lei no } 259 \text {, de } 5 \text { de maio de } 1992 \text {, e dá outras } \\
\text { providências. }\end{array}$ \\
\hline $259 / 1992$ & Altera dispositivos da Lei $n^{0} 235$, \\
\hline $235 / 1992$ & Regulamenta o funcionamento das feiras livres e per \\
\hline
\end{tabular}

Fonte: Distrito Federal, 2014. 